
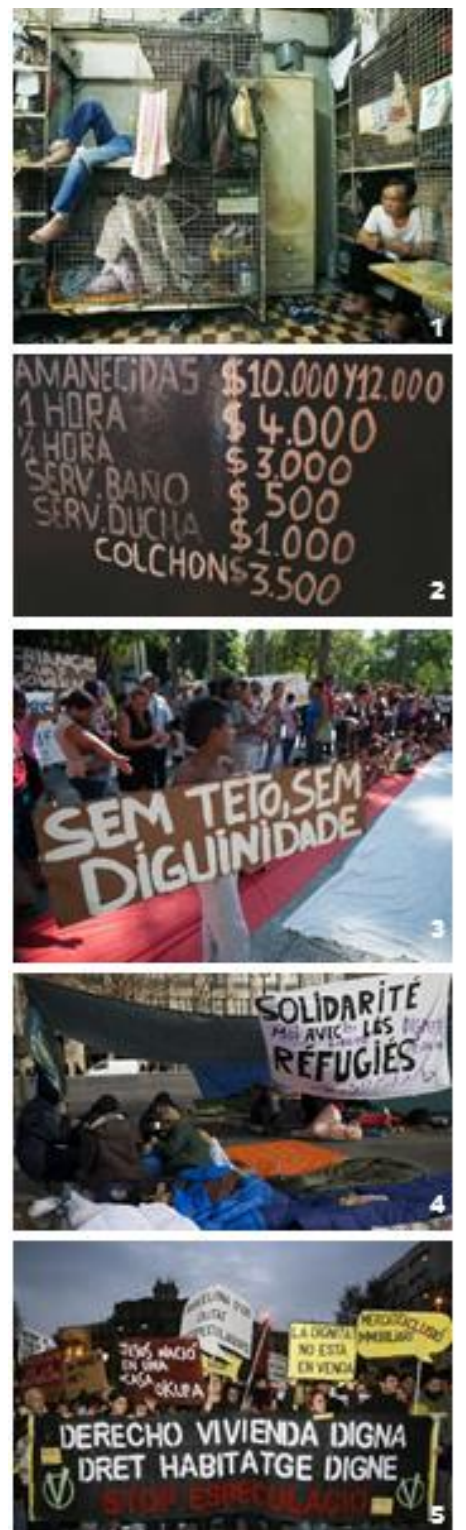

\title{
Moradia Adequada e Dignidade Humana na Experiência Espacial
}

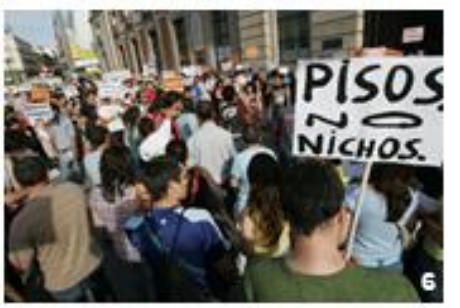

\section{Por: Arq. Mónica Elizabeth Mejia-Escalante}

Orientadora: Prof. Dr. Maria Lucia Refinetti R. Martins

BAD HOUSING : HOW BAD DOES IT HAVE TO GET BEFORE WE TAKEACTION? 企

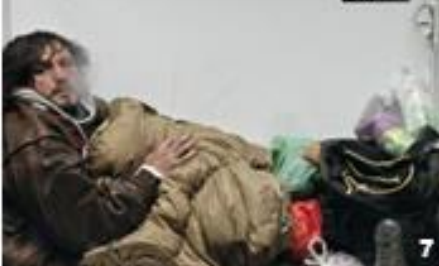

Doutorado em Arquitetura e Urbanismo

Universidade de São Paulo, Brasil / Faculdade de Arquitetura e Urbanismo / Habitat
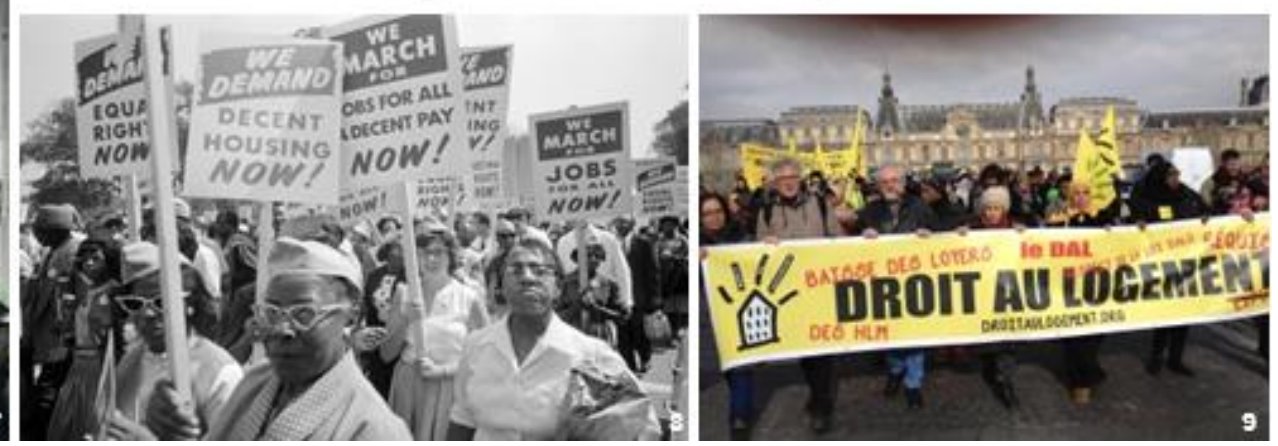
Fontes das imagens da capa. Online a abril de 2016 :

1. http://www.taringa.net/post/info/4910717/Los-hombres-jaula-el-lado-oscuro-de-Hong-Kong.html

2. http://www.semana.com/nacion/galeria/bronx-en-bogota-prostitucion-desapariciones-microtrafico/476358\#cxrecs_s

3. http://www.ebc.com.br/cidadania/galeria/imagens/2014/01/sem-teto-reivindicam-no-centro-de-sao-paulo-moradiadigna-confira

4. http://www.semana.com/mundo/articulo/refugiados-en-europa-tendran-mas-problemas-en-2016/455619-3

5. http://rock.marshall.free.fr

6. http://www.pixelydixel.com/2006/05/segunda-concentracion-por-el-derecho-a-una-vivienda-digna.html

7. http://www.coloribus.com/adsarchive/prints/annual-decent-housing-campaign-the-ad-squatter-12660555/

8. http://thesociologicalcinema.tumblr.com/post/100756886735/we-demand-decent-housing-now-these-women

9. http://droitaulogement.org/page/4/?s 
Mónica Elizabeth Mejía-Escalante

\section{MORADIA ADEQUADA E DIGNIDADE HUMANA NA EXPERIÊNCIA ESPACIAL}

Tese apresentada ao Programa de Pós-Graduação da Faculdade de Arquitetura e Urbanismo da Universidade de São Paulo, para a obtenção do título de Doutor em Ciências

Área de Concentração: Habitat

Orientadora: Profa.Titular Dra. Maria Lucia Refinetti R. Martins

EXEMPLAR REVISADO E ALTERADO EM RELAÇÃO À VERSÃO ORIGINAL, SOB RESPONSABILIDADE DO AUTOR E ANUÊNCIA DO ORIENTADOR.

$O$ original se encontra disponível na sede do Programa São Paulo, 28 de novembro de 2016.

São Paulo

2016 
AUTORIZO A REPRODUÇÃO E DIVULGAÇÃO TOTAL OU PARCIAL DESTE TRABALHO, POR QUALQUER MEIO CONVENCIONAL OU ELETRÔNICO, PARA FINS DE ESTUDO E PESQUISA, DESDE QUE CITADA A FONTE.

\section{E-MAIL DA AUTORA:}

monicaescalante@usp.br

memejiae@unal.edu.co

Mejía-Escalante, Mónica Elizabeth

M516m Moradia adequada e dignidade humana na experiência espacial / Mónica Elizabeth Mejía-Escalante. -- São Paulo, 2016.

248 p. : il.

Tese (Doutorado - Área de Concentração: Habitat) - FAUUSP. Orientadora: Maria Lucia Refinetti Rodrigues Martins Exemplar revisado e alterado em relação à versão original

1. Habitação - Colômbia 2.Direitos humanos 3.Direitos sociais 4.Direito à moradia I.Título

CDU 711.58(86) 


\section{MORADIA ADEQUADA E DIGNIDADE HUMANA NA EXPERIÊNCIA ESPACIAL}

Tese apresentada ao Programa de Pós-Graduação da Faculdade de Arquitetura e Urbanismo da Universidade de São Paulo, para a obtenção do título de Doutor em Ciências.

Aprovado em:

Banca Examinadora

Prof. Dr.

Instituição:

Assinatura:

Prof. Dr.

Instituição:

Assinatura:

Prof. Dr.

Instituição:

Assinatura:

Prof. Dr.

Instituição:

Assinatura:

Prof. Dr.

Instituição:

Assinatura: 



\section{AGRADECIMENTOS}

Agradeço à Professora orientadora Maria Lucia Refinetti Martins, pela generosidade, pela confiança, pela paciência, pelos conhecimentos.

A Universidade de São Paulo, Brasil, pela riqueza do seu intercâmbio acadêmico e cultural, assim como pela exuberância e beleza do seu Campus Butantã. Sempre desfrutei estar em seus espaços. Às secretárias da Faculdade de Arquitetura e Urbanismo dessa universidade, pela ajuda e paciência, quando eu Ihes fazia muitas perguntas, na minha ignorância como estrangeira, sobre a forma de como fazer os procedimentos.

Às professoras da banca de qualificação, a Susana Pasternak e a Rosângela Paz, que com seus questionamentos reorientaram meu trabalho e me alentaram a continuar com este tema pouco estudado.

Agradeço à Universidade Nacional de Colombia pela concessão de uma Comisión de Estudios para cursar o Doutorado na Universidade de São Paulo, Brasil. A ColfuturoColômbia e a Colciencias-Colômbia pelas bolsas de auxílio financeiro.

Aos meus colegas professores e administradores da Escuela del Hábitat-Cehap, da Faculdade de Arquitetura da Universidad Nacional de Colombia, sede Medellín, pelo apoio, ajuda e confiança nesses quatro anos de meu afastamento.

Aos meus amigos colombianos, latinos e brasileiros que têm estado dispostos para me socorrer no cotidiano. À revisora por ter me ajudado com a escrita do português, de quem aprendi mais um pouco dessa maravilhosa língua.

A minha mãe, Miryam Escalante, que sempre esteve ao meu lado, apesar da distância entre os países.

Ao Jovany, meu esposo, companheiro, amigo, de quem sempre tive seu apoio e sua integridade, ao deixar a Colômbia e estar ao meu lado nesta aventura de estudar no exterior.

Ao meu filho Emmanuel, que iluminou minha vida e trouxe brincadeiras no meio do Doutorado. Ele é meu sol. 



\section{RESUMO}

MEJÍA-ESCALANTE, Mónica Elizabeth. Moradia adequada e dignidade humana na experiência espacial, 2016. 248p. Tese (Doutorado). Faculdade de Arquitetura e Urbanismo. Universidade de São Paulo, 2016.

A gênese, evolução e conteúdo das noções "moradia adequada" e "moradia digna" foi investigado nas resoluções e relatórios da Organização das Nações Unidas (ONU); nos indicadores de habitação e nas Constituições dos países da América Latina; na produção acadêmica compilada em grandes repositórios; nas Sentencias de Tutela da Corte Constitucional da Colômbia. Agentes da política urbana que utilizam indistintamente essas noções, e embora sejam expressões equivalentes, seu abarcamento conceitual se difere. $O$ objetivo desta pesquisa depara por elementos socioespaciais que configurassem a dimensão da dignidade na moradia, e que consideramos que vai mais além do padrão de moradia adequada; tomando o contexto colombiano por referência. Construir a abordagem histórica e institucional do conceito de "moradia adequada", determinar fatores socioespaciais que poderiam lesar a integridade do morador que habita em espaços inadequados, e discorrer sobre os elementos diferenciadores, relacionados à moradia adequada e à moradia digna, são os objetivos específicos. Vários âmbitos e agentes foram investigados: a ONU que dita diretrizes mandatórias sobre assentamentos humanos para os países-integrantes, e instaura o indicador "direito à moradia adequada", com o Pacto Internacional de Direitos Econômicos, Sociais e Culturais (PIDESC) de 1991. Os institutos estatísticos de 21 países da América Latina, que alojam metodologia e dados sobre indicadores de habitação, e consideram que o conteúdo da moradia adequada corresponde às variáveis que cada país aplica, mais as do indicador do Pidesc. Essas variáveis de habitação também são conteúdo material do direito à moradia, adjetivada como adequada, digna ou decente, nas constituições vigentes destas nações. A produção acadêmica que afirma que o conteúdo do direito à moradia adequada é a constituída no Pidesc de 1991, e que o problema da habitação deve ser debatido num marco de direitos. A prática jurídica e o entendimento do cidadão sobre o direito à moradia digna observam-se no âmbito social quando o morador interpõe demandas perante um juiz em sentencias de tutela da Corte Constitucional da Colômbia, na forma de fatos que violam o direito à moradia digna e, em certas ocasiões, a dignidade. Pelo que investigamos, nas sentencias, pela relação da dignidade com o espaço, na interação entre os indivíduos, e quando se está em busca de acesso a habitação; para encontrar três objetos de proteção da dignidade instaurados nas sentencias de tutela. Assim, descobrimos elementos socioespaciais recorrentes em uma sentencia quando se debate sobre a violação ao direito à moradia, com os quais poderíamos indagar pela proteção à integridade do homem no espaço, quando se está na busca de recursos espaciais como a moradia: morador vulnerado (demandante); agente vulnerador (demandado); objeto espacial em litígio; pretensão do demandante sobre esse objeto; conduta do vulnerador e elementos nos quais esse escuda a sua conduta; consequências da violação ao direito, observadas como dano à pessoa e dano ao patrimônio; a percepção a respeito das lesões pela violação ao direito à habitação. Esses elementos socioespaciais configuram fatores de observação da dimensão da dignidade na moradia, que - como proposta da tese - nomeamos como a dignidade na experiência espacial.

Palavras-chave: moradia adequada, moradia digna, direito à moradia, sentença, Colômbia, dignidade. 


\section{ABSTRACT}

MEJÍA-ESCALANTE, Mónica Elizabeth. Adequate housing and human dignity in space experience, 2016. 248p. Thesis (Ph.D). School of Architecture and Urbanism. University of Sao Paulo, 2016.

The genesis, evolution and content of the notions of "adequate housing" and "decent housing" were researched from ONU's resolutions and reports; from housing indicators and constitutions of Latin American countries; from academic production compiled in great repositories, from constitutional court writ judgments for protection of constitutional rights of Colombia. Areas of urban policy that use indistinctively these notions, and even though being equivalent, their conceptual limitation differs. The objective of this research discovers sociospatial elements that shape the dimension of dignity in housing and that we consider goes beyond the standard of adequate housing; taking the Colombian context as reference. The specific objectives are to build the historical and institutional approach of the concept of "adequate housing", to determine socio-spatial factors that could undermine the inhabitant's dignity that dwells in inadequate spaces and to expatiate in differentiator elements related to the adequate housing and the decent housing. Several areas were explored: United Nations that dictates mandatory regulations concerning human settlements for country members establishes the indicator "right to an adequate housing" with the International Covenant on Economic, Social and Cultural Rights (ICESCR) of 1991. The statistics institutes of 21 countries in Latin America, which hold methodology and data concerning housing indicators, and consider that the content of adequate housing, correspond to the variables that each country applies, plus the elements of the indicator "adequate housing" of ICESCR. These habitation variables are also material content of the right to housing, adjectivized as adequate, dignified or decent, in the current constitutions of these nations. The academic production stating that housing must be adequate according to indicators and discussed in a rights framework. The citizen's legal practice and understanding of the right to a decent housing is present in the social area with the inhabitant that files a suit before a judge, in Constitutional Court judgments of Colombia, in the form of facts that violate the right to housing, and on certain occasions, dignity. For this reason, we explore judgments due to the relationship between dignity and space, in the interaction between individuals when the access to housing is being pursued; to find three objects of dignity protection introduced in the writ judgments. That is how we discover recurring socio-spatial elements in a writ judgment when the violation of the right to housing is being debated, with which we could inquiry for the protection to the integrity of people in the space, when they are looking for space resources like habitation: undermined inhabitant (claimant); undermining agent (defendant); space object disputed; claimant's claim over that object; undermining agent's conduct and elements on which he shields his conduct; consequences of violating that right, observed as harm to the person and harm to the heritage; the perception about the injury by violation of the right to housing. These socio-spatial elements shape the factors to observe the dimension of dignity in housing, which, as proposal of this thesis, we denominated as dignity in space experience.

Keywords: adequate housing, decent housing, right to housing, writ judgments for protection of constitutional rights, Colombia, dignity. 


\section{RESUMEN}

MEJÍA-ESCALANTE, Mónica Elizabeth. Vivienda adecuada y dignidad humana en la experiencia espacial, 2016. 248p. Tesis (Doctorado). Faculdade de Arquitetura e Urbanismo. Universidade de São Paulo, 2016.

La génesis, evolución y contenido de las nociones "vivienda adecuada" y "vivienda digna" fue investigado en resoluciones e informes de las Naciones Unidas (ONU); en indicadores de vivienda y en Constituciones de los países de América Latina; en la producción académica compilada en grandes repositorios; en sentencias de tutela de la Corte Constitucional de Colombia. Ámbitos de la política urbana que utilizan indistintamente estas nociones, y que aun siendo equivalentes, su delimitación conceptual difiere. El objetivo de esta investigación busca descubrir elementos socioespaciales que configuren la dimensión de la dignidad en la vivienda, y que consideramos, va más allá del estándar de vivienda adecuada; tomando el contexto colombiano por referencia. Construir el abordaje histórico e institucional del concepto "vivienda adecuada", determinar factores socioespaciales que podrían vulnerar la integridad del morador que habita en espacios inadecuados, y debatir sobre los elementos diferenciadores relacionados a la vivienda adecuada y la vivienda digna, son los objetivos específicos. Varios agentes fueron indagados: las Naciones Unidas que dictan directrices mandatorias sobre asentamientos humanos para los países miembros, instaura el indicador "derecho a una vivienda adecuada" con el Pacto Internacional de Derechos Económicos, Sociales y Culturales (PIDESC) de 1991. Los institutos de estadística de 21 países de América Latina, que hospedan metodología y datos sobre indicadores de vivienda, y consideran que el contenido de la vivienda adecuada corresponde a las variables que cada país aplica, más los elementos del indicador "vivienda adecuada" del Pidesc. Esas variables de habitación también son contenido material del derecho a la vivienda, adjetivada como digna o decente, en las constituciones vigentes de estas naciones. La producción académica que afirma que el contenido del derecho a la vivienda es el constituido en el Pidesc de 1991, y que el problema de la vivienda debe ser debatido en un marco de derechos. La práctica jurídica y la comprensión del ciudadano sobre el derecho a la vivienda digna está presente en el ámbito social cuando el morador interpone demandas ante un juez, en sentencias de tutela de la Corte Constitucional de Colombia, en forma de hechos que violan el derecho a la vivienda, y en ciertas ocasiones, la dignidad. Por lo que indagamos en las sentencias por la relación de la dignidad con el espacio, en la interacción entre individuos cuando se está en la búsqueda de acceso a vivienda; para encontrar tres objetos de protección de la dignidad instaurados en las sentencias de tutela. Así descubrimos elementos socioespaciales recurrentes en una sentencia cuando se debate la violación al derecho a la vivienda, con los cuales podríamos indagar por la protección a la integridad del hombre en el espacio, cuando se está en la búsqueda de recursos espaciales como la vivienda: morador vulnerado (demandante); agente vulnerador (demandado); objeto espacial en litigio; pretensión del demandante sobre ese objeto; conducta del vulnerador y elementos en los cuales escuda su conducta; consecuencias de la violación del derecho, observadas como daño a la persona y daño al patrimonio; la percepción al respecto de las lesiones por la violación al derecho a la vivienda. Estos elementos socioespaciales configuran factores de observación de la dimensión de la dignidad en la vivienda, que -como propuesta de esta tesis- denominamos la dignidad en la experiencia espacial.

Palabras clave: vivienda adecuada, vivienda digna, derecho a la vivienda, sentencia, Colombia, dignidad. 



\section{LISTA DE QUADROS}

Quadro 1.1 Artigos relacionados à moradia na DUDH de 1948, no Draft de 1955 do Pidesc de 1966, no PIDESC de 1966 e de 1991.

Quadro 1.2 Lista cronológica dos eventos e documentos mais significativos da ONU que relatam o direito à moradia e assuntos conexos.

Quadro 2.1 Variáveis do Indicador de Necesidades Básicas Insatisfechas (NBI) aplicado nos países da América Latina.

Quadro 2.2 Variáveis do Déficit Quantitativo Habitacional nos países da América Latina. 69

Quadro 2.3 Variáveis do Déficit Qualitativo Habitacional nos países da América Latina. $\quad 70$

Quadro 3.1 Adjetivação dada à moradia nas Constituições dos países da América Latina e ano de adesão ao Pidesc.

Quadro 4.1 Quantidade de documentos por repositório de produção acadêmica e por expressões de busca, com corte para dezembro de 2014.

Quadro 5.1 Classificação em dois grupos dos sete elementos do Pidesc de 1991, feita pela Corte Constitucional da Colômbia.

Quadro 6.1 Componentes de uma sentencia de tutela como categorias de análise.

Quadro 6.2 Objeto espacial em litígio e sua relação com o tipo de programa de habitação na Colômbia para o qual o demandante poderia ter se aplicado.

\section{Quadros de Apêndices}

Quadro A1 Palavras-chave utilizadas para a seleção de documentos pertinentes no âmbito multilateral, institucional, acadêmico, jurídico e social mediado pelo judiciário.

Quadro B1 Instrumentos jurídicos internacionais em permeabilidade com o direito à moradia.

Quadro C1 Constituições vigentes da Colômbia e da Espanha. Comparação de artigos associados com o direito à moradia. 


\section{LISTA DE FIGURAS}

Figura.1 Etapas e componentes desta pesquisa. 32

Figura 1.1 Linha do tempo dos acontecimentos da ONU sobre moradia adequada. 59

Figura 2.1 Paralelo entre a evolução da noção de moradia adequada da ONU e corpos anexos, e os indicadores de habitação. $\quad 85$

Figura 3.1 Mapa com as variáveis de habitação que 21 países da América Latina aplicam. 94

Figura 3.2 Mapa com as adjetivações à moradia que a Constituição de cada pais instaura e ano da Constituição.

Figura 3.3 Acontecimentos da ONU mais relevantes sobre moradia adequada; problemas de habitação a solucionar pela ONU, expostos por período; evolução dos indicadores de habitação e suas variáveis; adjetivações à habitação dadas nas Constituições de 21 países da América Latina; e a evolução da noção de moradia adequada desde a ONU. Compêndio do âmbito multilateral e do institucional.

Figura 6.1 Esquema metodológico para a construção de esquemas argumentativos, configurado pelos elementos recorrentes em uma sentencia na qual o direito à moradia é violado.

Figura 6.2 Desagregação da noção "Direito à Moradia Digna" da jurisprudência da Colômbia, classificada pelos objetos de proteção da dignidade da sua Corte Constitucional. A permeabilidade da noção do direito à moradia digna com os elementos da "Moradia Adequada" do Pidesc de 1991 e com os princípios da "Moradia Saudável" da OMS de 1990.

Figura 6.3 Objetos espaciais em litígio nos esquemas argumentativos e sua permeabilidade com os instrumentos jurídicos de direito internacional, invocados nas sentencias da Corte Constitucional da Colômbia.

Figura 7.1 Autores que expõem diversas acepções à dignidade, classificadas como dignidade intrínseca, dignidade atribuída e dignidade na experiência.

Figura 7.2 Compêndio dos fatores de observação da dignidade na experiência espacial habitacional.

\section{Figuras de Apêndices}

Figura D1 Esquema argumentativo: [I] moradia ou lote 100\% subsidiado e concedido à população vulnerável.

Figura D2 Esquema argumentativo: [II] subsídio de moradia para a população em deslocamento forçado.

Figura D3 Esquema argumentativo: [III] segurança da posse por despejos.

Figura D4 Esquema argumentativo: [IV] assistência humanitária para pessoas em situação de deslocamento forçado.

Figura D5 Esquema argumentativo: [V] assistência humanitária para danificações por desastres associados à temporada de inverno.

Figura D6 Esquema argumentativo: [VI] crédito hipotecário.

Figura D7 Esquema argumentativo: [VII] provisão de abastecimento de água potável e de rede de esgoto.

Figura D8 Esquema argumentativo: [VIII] intimidade e sossego, empresa em área residencial.

Figura D9 Esquema argumentativo: [IX] habitação: inviolabilidade, privacidade, livre circulação. 


\section{LISTA DE ABREVIATURAS E SIGLAS}

\section{LISTA DE ABREVIATURAS}

$\begin{array}{ll}\text { ALC } & \text { América Latina e O Caribe } \\ \text { AL } & \text { América Latina } \\ \text { Art. } & \text { Artigo } \\ \text { C.C. } & \text { Corte Constitucional da Colômbia } \\ \text { M.P. } & \text { Magistrado Ponente } \\ \text { SC } & \text { Sentencia de Constitucionalidad } \\ \text { ST } & \text { Sentencia de Tutela } \\ \text { SU } & \text { Sentencia de Unificación } \\ \text { C-xxx } & \text { Número de Sentencia de Constitucionalidad } \\ \text { T-xxx } & \text { Número de Sentencia de Tutela }\end{array}$

\section{LISTA DE SIGLAS}

A seguir a lista de siglas contidas no texto. Apresentam-se na ordem das siglas em inglês, espanhol e português, se for o caso de existir uma forma oficial nas duas últimas línguas.

\section{Organizações e programas conexos com a Organização das Nações Unidas (ONU)}

American Declaration of the Rights and Duties of Man
Declaración Americana de los Derechos y Deberes del Hombre

$\begin{array}{ll}\text { ECOSOC } & \text { Economic and Social Council } \\ \text { ECOSOC } & \text { Consejo Económico y Social de Naciones Unidas } \\ \text { ECOSOC } & \text { Conselho Econômico e Social das Nações Unidas }\end{array}$

FAO

FAO

FAO

$\mathrm{HIC}$

$\mathrm{HIC}$

HIC

ICCPR

PIDCP

PIDCP

ICESCR

PIDESC

PIDESC

IDPs

ILO

OIT

OIT
Food and Agriculture Organization of the United Nations Organización de las Naciones Unidas para la Alimentación y la Agricultura Organização das Nações Unidas para a Alimentação e a Agricultura

Habitat International Coalition

Coalición Internacional del Hábitat.

Coalizão Internacional do Hábitat

International Covenant on Civil and Political Rights

Pacto Internacional de Derechos Civiles y Políticos

Pacto Internacional sobre Direitos Civis e Políticos

International Covenant on Economic, Social and Cultural Rights

Pacto Internacional de Derechos Económicos, Sociales y Culturales

Pacto Internacional sobre Direitos Econômicos, Sociais e Culturais

Internally Displaced Persons

International Labour Organization

Organización Internacional del Trabajo

Organização Internacional do Trabalho. 
MDG Millennium Development Goals

ODM Objetivos de Desarrollo Del Milenio

ODM Objetivos de Desenvolvimento do Milênio

NGO Non-Governmental Organization

ONG Organización No Gubernamental

ONG Organização Não Governamental

UDHR Universal Declaration on Human Rights

DUDH Declaración Universal de los Derechos Humanos

DUDH Declaração Universal dos Direitos Humanos

UN United Nations

ONU Organización de las Naciones Unidas

ONU Organização das Nações Unidas

UNCED United Nations Conference on Environment and Development-Earth Summit

CNUMAD Conferencia de las Naciones Unidas sobre Medio Ambiente y Desarrollo-Cumbre de la Tierra

CNUMAD Conferência das Nações Unidas sobre Meio Ambiente e Desenvolvimento

UNEP United Nations Environment Programme

PNUMA $\quad$ Programa de las Naciones Unidas para el Medio Ambiente

PNUMA Programa das Nações Unidas para o Meio Ambiente

UNESCO United Nations Educational, Scientific and Cultural Organization

UNESCO Organización de las Naciones Unidas para la Educación, la Ciencia y la Cultura

UNESCO Organização das Nações Unidas para a Educação, a Ciência e a Cultura

UN-Habitat United Nations Centre for Human Settlements Programme

ONU-Hábitat Programa de las Naciones Unidas para los Asentamientos Humanos

UNHPR United Nations Housing Rights Programme

UNCHS United Nations Centre/Commission on Human Settlements

CNUAH Centro de las Naciones Unidas para los Asentamientos Humanos

WHO World Health Organization

OMS

OMS

OIHP

WSSD World Summit on Sustainable Development - Earth Summit 2002

Cumbre de la Tierra de Johannesburgo

WUF World Urban Forum

FUM Foro Urbano Mundial 


\section{Outras Siglas}

BNA Basic Needs Approach to Development

$\mathrm{NBI} \quad$ Necesidades Básicas Insatisfechas

$\mathrm{NBI} \quad$ Necessidades Básicas Insatisfeitas

CNA Canasta normativa de alimentos

CNA Cesta Normativa de Alimentos

CEPAL Comisión Económica para América Latina y El Caribe

COHRE Centre on Housing Rights and Evictions

DADH Declaración Americana de los Derechos y Deberes del Hombre

DADH Declaração Americana sobre os Direitos e Deveres do Homem

HIC Habitat International Coalition

INDEC Instituto Nacional de Estadística y Censos de Argentina

LP Línea de Pobreza

LP L Linha de Pobreza

MMIP Método de Medición Integrado de la Pobreza

PNUD Programa de las Naciones Unidas para el Desarrollo

PNUD Programa das Nações Unidas para o Desenvolvimento

PVHA Personas viviendo con HIV e AIDS

PVHA Pessoas vivendo com HIV e AIDS

\section{Contexto da Colômbia}

DNP

Departamento Nacional de Planeación de Colombia

FRECH Programa de Cobertura Condicionada de Tasa de Interés para la Adquisición de Viviendas Nuevas tipo VIP y VIS, para hogares de bajos ingresos y hasta ocho (8) SMMLV con acceso a crédito

PIPE Programa de Cobertura Condicionada de Tasa de Interés para la Adquisición de Viviendas tipo NO VIS con precio mayor a 135 SMMLV, para hogares de ingresos medios con acceso a crédito

PVG Programa de Vivienda Gratuita

RUV Registro Único de Víctimas

SFVE Subsidio Familiar de Vivienda en Especie

SMMLV Salario Mínimo Mensual Legal Vigente

VIPA Programa de Vivienda de Interés Prioritario para Ahorradores

VIP Vivienda de Interés Prioritario

VIS Vivienda de Interés Social 



\section{MORADIA ADEQUADA E DIGNIDADE HUMANA NA EXPERIÊNCIA ESPACIAL}

\section{SUMÁRIO DE DEFESA}

INTRODUÇÃO ................................................................................................23

A trajetória do questionamento sobre a habitabilidade na moradia ................................23

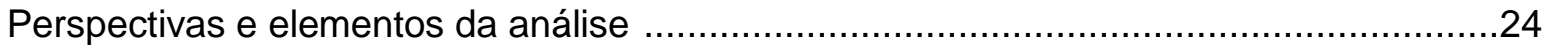

O estado do debate no mundo e na Colômbia a respeito da moradia adequada .............25

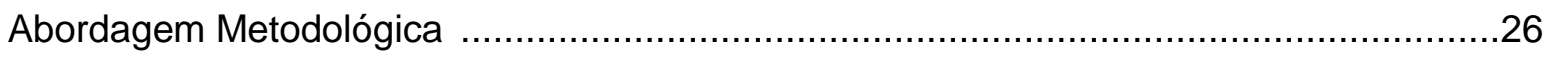

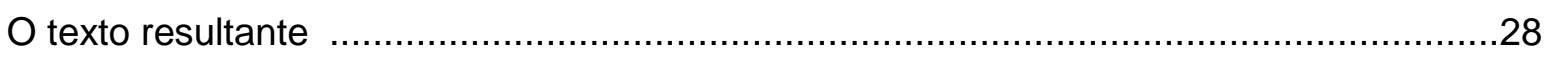

\section{A MORADIA ADEQUADA. EVOLUÇÃO NOS DOCUMENTOS DA} ORGANIZAÇÃO DAS NAÇÕES UNIDAS (ONU)

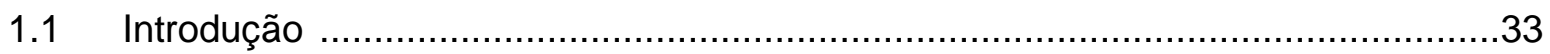

1.2 Documentos da ONU como instituição que dá origem à noção

"moradia adequada". Abordagem metodológica ....................................................34

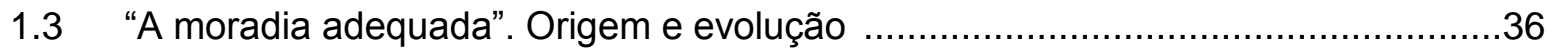

1.3.1 Enfrentar o "abrigo de emergência" na Europa. Diagnóstico sobre a habitação no mundo [1946 - 1960]

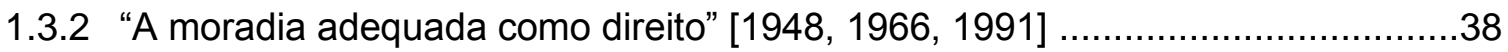

1.3.2.1 O "direito a um nível de vida adequado". A moradia na Declaração Universal dos Direitos do Homem [1948-1966]

1.3.2.2 A "moradia como componente do direito a um nível de vida adequado".

Pacto Internacional de Direitos Econômicos, Sociais e Culturais (PIDESC) [1966]

1.3.2.3 O "direito à moradia adequada". Pacto Internacional de Direitos Econômicos, Sociais e Culturais (PIDESC) [1991]

1.3.3 A "moradia econômica e os serviços comunitários conexos". Assistência técnica, financiamento externo, mutirão e outras formas de associação [1952-1970]

1.3.4 Desde "sem fome no mundo" até "cidades sem bairros de tugúrios". Decênios para o Desenvolvimento e a Declaração do Milênio [1960-2000]

1.3.5 A "moradia como um componente do nível de vida", enfoque paralelo [Décadas 1960 e 1970]

1.3.6 De "Necessidades Básicas" ao Indicador de "Necessidades Básicas Insatisfeitas (NBI)" [1970-1990] 
1.3.7 De problemas no "meio humano" a problemas no "meio ambiente" [1968, 1972, 1992]

1.3.8 "Assentamentos humanos". Conferência mundial Hábitat I [1976], Hábitat II [1996], Hábitat III [2016]

1.4 A "Moradia Adequada" desde as Nações Unidas como agente multilateral. Síntese

\section{A MORADIA ADEQUADA NOS INDICADORES DE HABITAÇÃO DOS} INSTITUTOS ESTATÍSTICOS DA AMÉRICA LATINA

2.1 Introdução. Importância dos indicadores habitacionais

2.2 Indicadores de Habitação dos países da América Latina. Abordagem metodológica

2.3 De necessidades básicas ao Indicador de Necessidades Básicas Insatisfeitas (NBI). Gênese das variáveis do Déficit Habitacional nos países da América Latina

2.4 Déficit Habitacional Quantitativo e Qualitativo. Variáveis .....................................68

2.4.1 Variáveis de Déficit Quantitativo e suas definições. [Quadro 2.2] ......................72

2.4.2 Variáveis de Déficit Qualitativo e suas definições. [Quadro 2.3] .........................76

2.5 Variáveis de Déficit Habitacional e Elementos da Moradia Adequada do Pidesc de 1991 .79

2.6 A "Moradia Adequada" desde os Indicadores de Habitação dos países da América Latina, como produção estatística. Síntese

\section{ADJETIVAÇÕES À MORADIA NAS CONSTITUIÇÕES DOS PAÍSES DA} AMÉRICA LATINA E O MÍNIMO DOS DIREITOS HABITACIONAIS

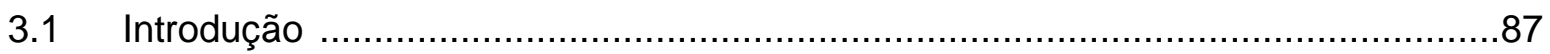

3.2 Constituições dos países da América Latina. Abordagem metodológica ...............88

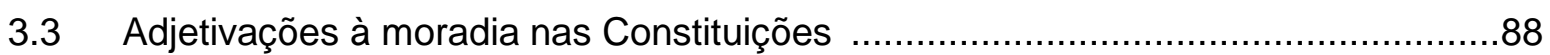

3.4 A "Moradia Adequada, Digna, Decente, Segura, Higiênica" nas Constituições dos países da América Latina e o mínimo dos direitos habitacionais. Síntese

\section{A MORADIA ADEQUADA E A MORADIA DIGNA. ESTADO DO DEBATE NA LITERATURA ACADÊMICA}

4.1 Introdução

4.2 A produção acadêmica sobre a questão da moradia. Abordagem metodológica ...98 
4.3 Vertentes, temas e debates na produção acadêmica sobre habitação 101

4.3.1 Política de habitação …....................................................................... 102

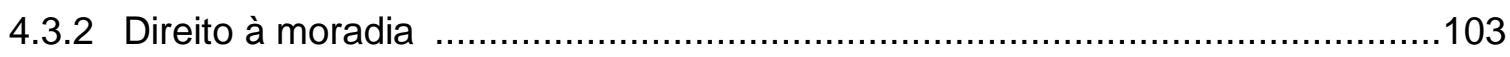

4.3.2.1 Direito à moradia desde um olhar crítico aos instrumentos jurídicos de direito internacional, em permeabilidade com esse direito ..................104

4.3.2.2 A moradia em sua eficiência funcional e por sua vez como um direito ......106

4.3.3 Moradia adequada para indivíduos com condições especiais de saúde

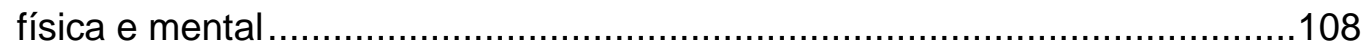

4.4 A "moradia como direito" e a dignidade na sua dimensão prática . Síntese do âmbito acadêmico

5.1 Introdução

5.2 O direito à moradia na jurisprudência da Colômbia. Abordagem metodológica ...115

5.3 Gênese e evolução da noção do direito à moradia na Colômbia 118

5.3.1 Do direito do colono a explorar o solo conquistado, ao direito do cidadão à moradia digna

5.3.2 O direito à moradia digna nas Sentencias de Tutela entre 1992 e 2014

5.3.3 O direito à moradia digna nas Sentencias de Tutela e sua permeabilidade com os instrumentos jurídicos de direito internacional

5.4 Do direito de explorar as terras conquistadas ao direito à moradia digna.

Síntese desde o âmbito jurídico da Colômbia

\section{ELEMENTOS SOCIOESPACIAIS EM SENTENCIAS DE TUTELA DA COLÔMBIA, COMO CONTEÚDO DO DIREITO À MORADIA DIGNA}

6.1 Introdução

6.2 Esquemas argumentativos desde sentencias da Corte Constitucional da Colômbia sobre a violação ao direito à moradia digna. Abordagem metodológica

6.3 O dano e a lesão na violação ao direito à moradia e à dignidade

6.3.1 Três objetos de proteção da dignidade: viver como quiser, viver bem e viver sem humilhação. A jurisprudência da Colômbia

6.3.1.1 Lesão ao projeto de vida - viver como quiser

6.3.1.2 Lesão às condições materiais de existência - viver bem

6.3.1.3 Lesão à intangibilidade dos bens não patrimoniais - viver sem humilhação 
6.4 Esquemas argumentativos: análise desde sentencias de tutela que expõem a violação ao direito à moradia digna

6.4.1 O direito à moradia digna como um dever ser e sua colateralidade com outros direitos pela conduta dos demandados

6.4.2 As condutas do demandado e a lesão ao demandante 158

6.5 Elementos socioespaciais no direito à moradia digna. Síntese

\section{A DIGNIDADE HUMANA NA EXPERIÊNCIA ESPACIAL COMO ATRIBUTO DA MORADIA ADEQUADA}

7.1 Introdução

7.2 A dignidade humana em suas diversas acepções 168

7.3 A dignidade humana na experiência espacial 176

7.3.1 A dignidade humana na experiência espacial: fatores de observação e entidades lesadas

7.3.2 Critérios de proteção do direito à moradia que incluiria o amparo da dignidade humana na experiência espacial

8 SINTESE E CONCLUSÕES

8.1 A moradia adequada e a moradia digna segundo os diferentes agentes.

Síntese

8.2 Moradia adequada e dignidade humana na experiência espacial habitacional num marco de direitos. Conclusões

8.3 Temas para futuras pesquisas

\section{APÊNDICES}

APÊNDICE A - Palavras-chave utilizadas para a seleção de documentos pertinentes no âmbito multilateral, institucional, acadêmico, jurídico e social mediado pelo judiciário. ..231 APÊNDICE B - Os instrumentos jurídicos Internacionais em permeabilidade com o direito à moradia

APÊNDICE C - Constituições vigentes da Colômbia e da Espanha. Comparação de artigos associados com o direito à moradia.

APÊNDICE D - Esquemas argumentativos sobre o direito à moradia, desde sentencias da Corte Constitucional da Colômbia. 


\section{INTRODUÇÃO}

\section{A trajetória do questionamento sobre a habitabilidade na moradia}

"A moradia digna" é uma expressão cotidiana que se observa em vários âmbitos: na rua, quando se publica um projeto residencial intitulado como moradia digna (mas com o acesso à habitação a partir de uma entrada e o restante por crédito hipotecário); na conversa entre duas mulheres no transporte público (expressando sua felicidade por já ter um teto para morar com seus filhos, graças ao apartamento que Ihe foi concedido pelo governo por ser mulher chefe de família); nos programas institucionais do governo de rádio ou de televisão sobre programas de habitação (recém-proprietários que, por sua condição de vulnerabilidade e baixa capacidade econômica, receberam um domicílio 100\% subvencionado, manifestam seu bem-estar e agradecem ao governo com frases como "finalmente tenho minha própria moradia"); nos discursos dos prefeitos que mostram o número de domicílios construídos num período de governo, enunciando que "nós estamos cumprindo metas, $\mathrm{X}$ número de moradias dignas".

É a partir de todas essas situações, que a presente tese questiona se uma moradia digna significa moradia própria e se todos os domicílios são dignos. Este questionamento quanto à expressão "moradia digna" vem sendo feito desde a graduação de arquitetura há 15 anos, ao observar as condições espaciais dos domicílios, dos bairros precários; e das barracas construídas com papelão e madeira. Assim, emergiram perguntas: como é que um morador vive com carências espaciais tão evidentes a olho nu? São essas carências "habitacionais"? Este habitante tem optado por viver assim ou foi a escolha adotada diante de sua capacidade econômica? São moradias abaixo do nível de dignidade ou apenas são nomeadas de informais, ilegais, irregulares, tugúrios, favelas, de acordo com o regulamento de habitação que não atendem? Alguns funcionários da Prefeitura de Medellín, Colômbia, designam esses domicílios como inadequados, mas não como não dignos. Inadequados a respeito do quê? Por que nunca se ouve a qualificação de indigno para o espaço?

Todas estas questões, que também circundaram esta pesquisa de doutorado, foram sendo abordadas em vários momentos do trabalho profissional e acadêmico, e ao mesmo tempo gerando investigações: o projeto final da graduação em Arquitetura da Universidade Nacional da Colômbia, que consistiu numa habitação de emergência para pessoas que precisavam de habitação temporária porque perderam seu imóvel em desastre natural ou porque ficaram desabrigadas por causa do conflito armado na Colômbia; o mestrado em Habitat na mesma Universidade, que foi uma pesquisa sobre a discrepância entre a venda de um modo de vida oferecido pelos anúncios imobiliários e as condições reais espaciais dos projetos de habitação, para todas as 
camadas sociais de Medellín, que anunciavam as moradias como: dignas, decentes, maravilhosas, um sonho, uma nova vida, etc.; pesquisas enquanto professora da Universidade Nacional da Colômbia nos últimos oito anos, com temas como indicadores de habitação, planos diretores, despejos por obras de desenvolvimento; aulas ministradas sobre o tema da habitação (desafiando os alunos de que alguns deles ignoravam as qualidades e carências do seu bairro ou do seu domicílio, e só pensavam em projetar a "casa de autor" para um único usuário, ou um belo bairro com todos os serviços, apenas na prancheta). Assim, surgiram outras perguntas: Que tipo de habitação é oferecida na Colômbia para a população vulnerável? Porque os projetos de moradia social hoje, e desde 2004, são anunciados em Medellín como "viviendas dignas con corazón"?

As investigações e perguntas mencionadas têm privilegiado a discussão sobre a habitabilidade e as variáveis de habitação que tornavam possível uma condição de bem-estar para o morador. Daí surge a questão que motivou a pesquisa de doutorado: Porque na política de assentamentos humanos e de habitação, na publicidade de imóveis, nos programas de reabilitação e de melhoria de bairros, na conversa diária quando se comenta que um domicílio é concedido à população vulnerável, é atribuído o qualificativo de "moradia digna"? Não obstante, quando nos referimos a dados resultantes de diagnósticos residenciais, falamos de "moradia adequada"; mas estamos continuamente convivendo com carências habitacionais nas nossas cidades, sem saber o que a moradia "adequada" ou "digna" abarca. É a partir desse percurso que se configurou o interesse por compreender o significado da "moradia adequada" e da "moradia digna" desenvolvido nesta tese.

\section{Perspectivas e elementos da análise}

Em abordagens preliminares desta investigação observou-se que as noções de "moradia adequada" e "moradia digna" têm sido usadas indistintamente nos relatórios de organizações multilaterais como a ONU, nos diagnósticos e políticas de habitação dos países da América Latina, em grande parte da produção acadêmica, no universo jurídico colombiano (Sentencias de Tutela da sua Corte Constitucional), no mercado imobiliário, na publicidade. Mas essas noções "moradia adequada" e "moradia digna" ainda que estejam relacionadas e se complementem, naquilo que abarcam conceitualmente, diferem. Daí o propósito da presente pesquisa de investigar o conteúdo desses conceitos a partir desses diferentes agentes formuladores de conteúdo.

Várias perguntas direcionaram esta investigação: Qual é a delimitação conceitual da moradia adequada e os agentes que a criam? Qual é a delimitação conceitual de moradia digna e os agentes que a instituem? Por que a "moradia digna" é usada no 
discurso político habitacional, na publicidade de imóveis, nos noticiários e em conversas cotidianas, mas o indicador aplicado é "moradia adequada", caracterizada com indicadores e dados? O digno da moradia pode ser violado? A dignidade pode ser violada? E, ao ser afirmativa a resposta, a violação à dignidade pode ser observada no corpo, nas condições materiais de existência ou na moradia? E qual é afinal a dignidade violada: da moradia, do espaço, da norma, das condições de existência, do corpo?

As respostas a estas questões, que, ao mesmo tempo, justificam esta investigação, possibilitaram tornar visível o uso indistinto das noções em estudo, e localizar cada uma delas no seu próprio âmbito conceitual. Isto é necessário porque está sendo transmitido para o habitante que a moradia fornecida pelo agente público ou particular, é "moradia digna", quando o que se observa nas cidades, através do que é narrado em demandas de sentencias da Corte Constitucional da Colômbia e o que é ouvido no discurso diário, é que esses domicílios, ocasionalmente, não cumprem padrões de habitabilidade, estipulados em indicadores de habitação, os quais são o conteúdo material do direito à habitação.

Esta pesquisa se propôs deparar elementos socioespaciais que configurassem a dimensão da dignidade na moradia, com referência no contexto colombiano como objetivo geral. Buscou construir a abordagem histórica e institucional acerca do conceito de "moradia adequada"; determinar fatores socioespaciais que poderiam lesar a integridade do morador que habitava em espaços inadequados; e discorrer sobre os elementos diferenciadores e complementares relacionados à moradia adequada e à moradia digna.

\section{O estado do debate no mundo e na Colômbia a respeito da moradia adequada}

A noção do direito à moradia adequada, contida no Pacto Internacional de Direitos Econômicos, Sociais e Culturais (PIDESC) de 1991, é considerada pelos especialistas como o instrumento jurídico Internacional mais relevante na questão dos direitos habitacionais. $O$ direito à moradia adequada significa ter mais do que um abrigo para se proteger do clima e dos vetores de enfermidades externas; significa também um lugar no qual se tenha privacidade e espaço suficiente para o indivíduo desenvolver a sua própria vida e a sua cultura, construído com materiais duráveis e seguros; com iluminação, aquecimento e ventilação suficientes; com infraestrutura básica adequada para serviços de água, esgoto e eliminação de resíduos; com acesso aos serviços urbanos; com segurança da posse; e, tudo isso, a um custo razoável.

As variáveis de moradia têm uma estreita relação com as adjetivações dadas à habitação nas Constituições dos países da América Latina; razão pelo qual essas 
variáveis são chamadas para ser consideradas como o conteúdo prático do direito à habitação. A "moradia adequada" como indicador institucionalizado pelo Pidesc de 1991 é uma noção encontrada em oito das Constituições dos 21 países revisados, e que datam de anos antes do Pidesc de 1991. "Moradia digna" é instaurada em oito das Cartas Políticas deste continente; sendo invocadas indistintamente ambas expressões em várias áreas da política urbana.

O contexto acadêmico também ofereceu um estado da arte sobre o pensar a moradia adequada e a digna, a partir da produção acadêmica, a qual está compilada em grandes repositórios, para vislumbrar três vertentes em que se move o debate sobre a habitação, mais que esse debate deve ser num marco de direitos.

No âmbito da jurisprudência, a noção colombiana do direito à moradia digna, reconstruída a partir da análise das sentencias da sua Corte Constitucional, é uma expressão do influxo do Pidesc de 1991, de outros instrumentos de direito internacional e das variáveis do déficit habitacional desse país.

Essa noção de moradia digna explicita que a dignidade deve ser protegida, porquanto poderia ser vulnerada por ações externas. Nessa perspectiva de salvaguardar a dignidade, a Corte Constitucional da Colômbia construiu três objetos de proteção da dignidade em 2002, e estabelecidos como precedente para subsequentes sentencias, tais como: (I) a dignidade humana, entendida como autonomia ou possibilidade de projetar um plano de vida; (II) a dignidade humana entendida como certas condições materiais específicas de existência; (III) a dignidade humana que se compreende como a intangibilidade dos bens não patrimoniais, a integridade física e a moral. (C.C. T-881, 2002). ${ }^{1}$.

\section{Abordagem Metodológica}

Para responder aos interrogantes da pesquisa, foi desenvolvida uma ampla revisão de documentos no âmbito multilateral, institucional e acadêmico, o que

\footnotetext{
${ }^{1}$ Nesta tese vão ser nomeadas as expressões Acción de Tutela, Sentencia e Sentencia de Tutela pelas indicações em espanhol respectivamente: acción de tutela, sentencia, sentencia de tutela.

Seguem, portanto, alguns esclarecimentos a respeito da palavra "Tutela". Em primeiro lugar, em espanhol, em que ela tem várias acepções: "1. Autoridad que, en defecto de la paterna o materna, se confiere para cuidar de la persona y los bienes de aquel que, por minoría de edad o por otra causa, no tiene completa capacidad civil. 2. Cargo de tutor. 3. Dirección, amparo o defensa de una persona respecto de otra" (REAL ACADEMIA ESPAÑOLA, 2015). E, em segundo, Tutela, em português, que significa "autoridade legal sobre uma pessoa menor ou interdita" (PORTO EDITORA, 2003). Assim, verificam-se duas acepções distintas entre as duas línguas. Sempre que expressar nesta tese a palavra "tutela", será sob o significado em espanhol com a terceira definição. Esclarecimento feito no Capítulo 5 , Nota de Rodapé $N^{\circ} .47$.
} 
desenhou o contexto e forneceu a discussão teórica no âmbito internacional e da Colômbia. O levantamento empírico iniciou-se com o agente social, que é mediado por um juiz, com sentencias de tutela da Corte Constitucional da Colômbia, que expõe os fatos que o demandante percebe, conduzem à violação ao direito à moradia. No entanto, o judiciário vai implantando um conteúdo do direito à moradia digna para a Colômbia, como discussão teórica. Deste modo, foi identificado, desde cada âmbito, a gênese, a evolução e o conteúdo das noções em questão: moradia adequada e moradia digna.

Esta investigação é de ordem qualitativa e empírica, definindo a modalidade qualitativa como:

[...] qualquer tipo de pesquisa que produza resultados não alcançados através de procedimentos estatísticos ou de outros meios de quantificação. [...]. Alguns dados podem ser quantificados, como no caso do censo ou de informações históricas sobre pessoas ou objetos estudados, [...], de uma forma que permita que sejam estatisticamente analisados, [...] mas o grosso da análise é interpretativa [...]. [A análise qualitativa] é o processo não matemático de interpretação, feito com o objetivo de descobrir conceitos e relações nos dados brutos e de organizar esses conceitos e relações em um esquema explanatório teórico (STRAUSS e CORBIN, 2008, p. 23).

Existem três componentes principais em que se apoia esta tese: a) dados; b) codificação; c) relatórios escritos e verbais.

a) Dados. Têm origem em documentos que correspondem aos âmbitos multilateral, institucional, acadêmico, jurídico e social mediado pelo judiciário.

b) Codificação. Permite conceituar e reduzir os "dados", elaborar categorias segundo suas propriedades e dimensões e relacioná-los por meio de uma série de declarações preposicionais. Passos referidos como codificação (STRAUSS e CORBIN, 2008).

c) Relatórios escritos e verbais. Podem ser apresentados como artigos em jornais científicos, palestras, etc. Alguns dos capítulos ou partes de capítulo desta pesquisa têm derivado em artigos apresentados pela autora em palestras e eventos ou têm sido publicados em periódicos da área de desenvolvimento urbano e de habitação.

A leitura sistematizada e a análise dos documentos de cada âmbito correspondem ao componente de codificação, e foram realizadas com o apoio da análise documental e de conteúdo. A análise documental é uma técnica que torna possível representar a informação de um texto em uma forma diferente do original, com base em uma classificação ou indexação temática, cujo fim é facilitar as consultas posteriores 
(ANDRÉU, 2002). Para a indexação temática, foram utilizadas palavras-chave, com as quais foi possível construir uma estrutura de categorias de análise, como passo preliminar para a análise de conteúdo; como técnica de investigação que permite fazer inferências ou dar explicações aplicadas a um contexto (BARDIN, 2002; KRIPPENDORFF, 1990). Essas palavras-chave que permitiram a indexação foram compiladas no Quadro A1, do Apêndice A. O software Excel foi o suporte para a recopilação e classificação dos textos a serem analisados, com base nessa indexação. O software Atlas.Ti, para análise qualitativa de dados, apoiou a análise de conteúdo, desde a indexação feita a partir da análise documental. Em cada um dos capítulos descrevo a abordagem metodológica mais detalhadamente.

Um processo de especial importância nesta pesquisa qualitativa é o ordenamento conceitual, que se define como "um conjunto de conceitos bem desenvolvidos relacionados por meio de declarações e de relações que, juntas, constituem uma estrutura integrada que pode ser usada para explicar ou prever fenômenos" (STRAUSS e CORBIN, 2008, p. 29). Assim, a interação entre a discussão teórica e o levantamento empírico permitiu, a partir de um ordenamento conceitual, instalar, como proposta da tese, o que se designou por dignidade na experiência espacial, como uma forma de compreender a dimensão da dignidade na moradia.

\section{O texto resultante}

O texto se organiza em quatro blocos, além desta introdução e das conclusões: as construções conceituais a respeito da moradia adequada e da moradia digna, formuladas pelos diversos agentes institucionais (capítulos 1 a 3), o debate na produção acadêmica no pesquisar sobre habitação adequada e digna (capítulo 4), o direito à moradia na jurisprudência colombiana (capítulos 5 e 6), a proposta interpretativa (capítulo 7), a síntese e as conclusões (capítulo 8).

O primeiro Capítulo mostra a relevância das Nações Unidas na provisão de critérios sobre políticas de habitação para os países-integrantes, bem como na criação do indicador "direito à moradia adequada" do Pacto Internacional de Direitos Econômicos, Sociais e Culturais (PIDESC) de 1991, o qual é aplicado, desde então, até hoje, para estabelecer o grau de moradia adequada dos países do mundo. Indago pela origem e evolução da noção "moradia adequada", a partir de recortes temporais entre 1946 ano da primeira resolução sobre moradia - e 2014; desde os vários adjetivos atribuídos à moradia. Termina com uma síntese sobre a gênese e evolução da noção "moradia adequada" desde este agente multilateral. 
A ONU também é fonte institucional de origem das variáveis do Déficit Habitacional dos países da América Latina ${ }^{2}$, o que consta do Capítulo 2, cujo propósito é identificar, a partir da revisão das variáveis de habitação que 21 países da América Latina aplicam, o que é considerado por estes a moradia adequada. Isto revela uma política de assentamentos humanos e de habitação com base em um conjunto de necessidades básicas constituído por: alimentação, abrigo, vestimenta, equipamentos domésticos, serviços básicos. Razão pelo que foi feita uma breve exposição sobre 0 Indicador de Necesidades Básicas Insatisfechas (NBI), aplicado na América Latina e $O$ Caribe (ALC). A seguir, uma definição das variáveis e dos indicadores de habitação que estas nações aplicam, e agrupados em Déficit Quantitativo e Qualitativo. A definição de cada variável é construída a partir de informações alojadas nos seus Institutos de Estatística. Esses indicadores foram revisados sob os critérios que configuram os métodos Directo e de Ingresos, os quais avaliam condições de vida e estabelecem as carências de necessidades básicas. Em seguida, uma comparação destas variáveis com os sete elementos do indicador "moradia adequada" do Pidesc de 1991. Para finalizar com uma síntese sobre o que é para a América Latina, a moradia adequada, desde os indicadores de habitação, e sua relação com o direito à moradia.

Nas Constituições dos 21 países da América Latina é examinado como cada nação qualifica a habitação, para apoiar o objetivo do Capítulo 3, de revisar a coerência entre as expressões encontradas nestas Cartas Políticas e as variáveis do Déficit Habitacional desses países. No final, uma síntese sobre o que poderia ser considerado o conteúdo material e objetivo do direito à moradia, e, assim, a importância dos indicadores de habitação.

No Capítulo 4 é apresentada a metodologia de coleta, classificação e análise de documentos compilados em grandes repositórios de produção acadêmica no mundo, encontrados sob as expressões de busca "moradia adequada" e "moradia digna" em Português, Espanhol e Inglês. Em seguida, são expostos vertentes e temas que emergiram, bem como os autores desde os quais se move o debate sobre a habitação no âmbito acadêmico. As vertentes resultantes foram: i) a política de habitação, ii) o direito à moradia, e iii) a moradia adequada para indivíduos com condições especiais de saúde física e mental. Na terceira vertente foram classificados autores que, a partir da área da saúde e da bioética, forneceram diversas acepções à dignidade, diferente daquela considerada inviolável e não mensurável. No final, algumas considerações sobre o debate acadêmico a respeito de pensar a habitação.

\footnotetext{
2 Países da América Latina revisados: Argentina, Bolívia, Brasil, Colômbia, Costa Rica, Cuba, Chile, Equador, El Salvador, Guatemala, Haiti, Honduras, México, Nicarágua, Panamá, Paraguai, Peru, Porto Rico, República Dominicana, Uruguai e Venezuela.
} 
No Capítulo 5 é iniciada a revisão do contexto colombiano a partir do âmbito jurídico, com uma breve introdução sobre o que é a Acción de Tutela e a Sentencia da Corte Constitucional da Colômbia, as quais, por sua vez, fazem parte dos documentos de análise. É apresentada a revisão da gênese e evolução do direito à moradia para essa nação, desde as Leyes de Indias, como a regulação do território por parte da Coroa da Espanha; logo as diversas Constituições até a vigente de 1991, na qual se constitui a moradia digna como um direito. A seguir, a evolução e a natureza desse direito, desde as primeiras sentencias do Tribunal colombiano, que datam de 1992, até as de 2014, para descobrir a noção vigente do direito à moradia digna, além da invocação do desrespeito à dignidade, quando debatida a violação ao direito à habitação. E, também, a permeabilidade e colateralidade dessa noção com outros instrumentos jurídicos de direito internacional. Para ao final, uma síntese sobre a gênese, evolução, natureza jurídica e a noção do direito à moradia para a Colômbia.

No Capítulo 6 prossegue a investigação na esfera jurídica da Colômbia, a partir das demandas da sociedade, tendo como objeto de análise um levantamento empírico, nas sentencias de tutela da Corte Constitucional da Colômbia entre 1992 e 2014. Não se trata de desenvolver uma análise do processo legislativo, nem a revisão da decisão do juiz a respeito da violação ao direito à habitação. O que se buscou foi pôr em evidência como o direito à moradia na Colômbia está sendo praticado, considerandose os fatos narrados nas sentencias, apresentados pelos demandantes como situações de violação do direito à moradia. Antecedendo a análise dos dados empíricos, é apresentada a abordagem metodológica de análise das sentencias a partir da construção de esquemas argumentativos, os quais mostraram situações em que se tem violado esse direito.

O Capítulo 7 constitui a síntese propositiva da tese. Apresenta a construção teórica do que se nomeou como a dignidade na experiência espacial. A sustentação para esse enunciado advém dos diversos levantamentos e análises desenvolvidos na tese, desde os Capítulos 1 a 6 . O texto revisa o conceito de dignidade e desenvolve a noção de dignidade na experiência espacial, correlacionando a proteção da dignidade humana à proteção do direito à moradia. Os fatores de observação dessa noção dignidade na experiência espacial-, são elementos descobertos na análise das sentencias, e considerados elementos recorrentes na forma de um padrão jurídicoespacial quando violado o direito à moradia.

Por fim, as conclusões são apresentadas no Capítulo 8, que retoma as considerações parciais do conjunto de capítulos precedentes. Começa por relacionar o que é, para os agentes do âmbito multilateral, institucional, jurídico, e social mediado pelo judiciário, a moradia adequada e a moradia digna. Discute-se então a diferença entre as duas noções, assumindo que são dois elementos complementares que não se 
excluem, mas que nenhum deles está inserido no outro, e que a imagem mental que o cidadão faz de cada noção é diferente. Os apontamentos enunciados a respeito da dignidade na experiência espacial, apresentados no Capítulo 7, trazem elementos para diferenciar e compreender a complementariedade entre a "moradia adequada" $\mathrm{e}$ a "moradia digna". Encerra-se com a identificação de alguns temas para futuras pesquisa e no âmbito das questões estudadas.

A Figura 1 traduz o desenvolvimento da pesquisa. Apresenta uma síntese da correspondência dos capítulos com os âmbitos e os agentes analisados, e com suas fontes de evidencia; também a principal questão tratada por Capítulo e a conclusão que se extrai. 


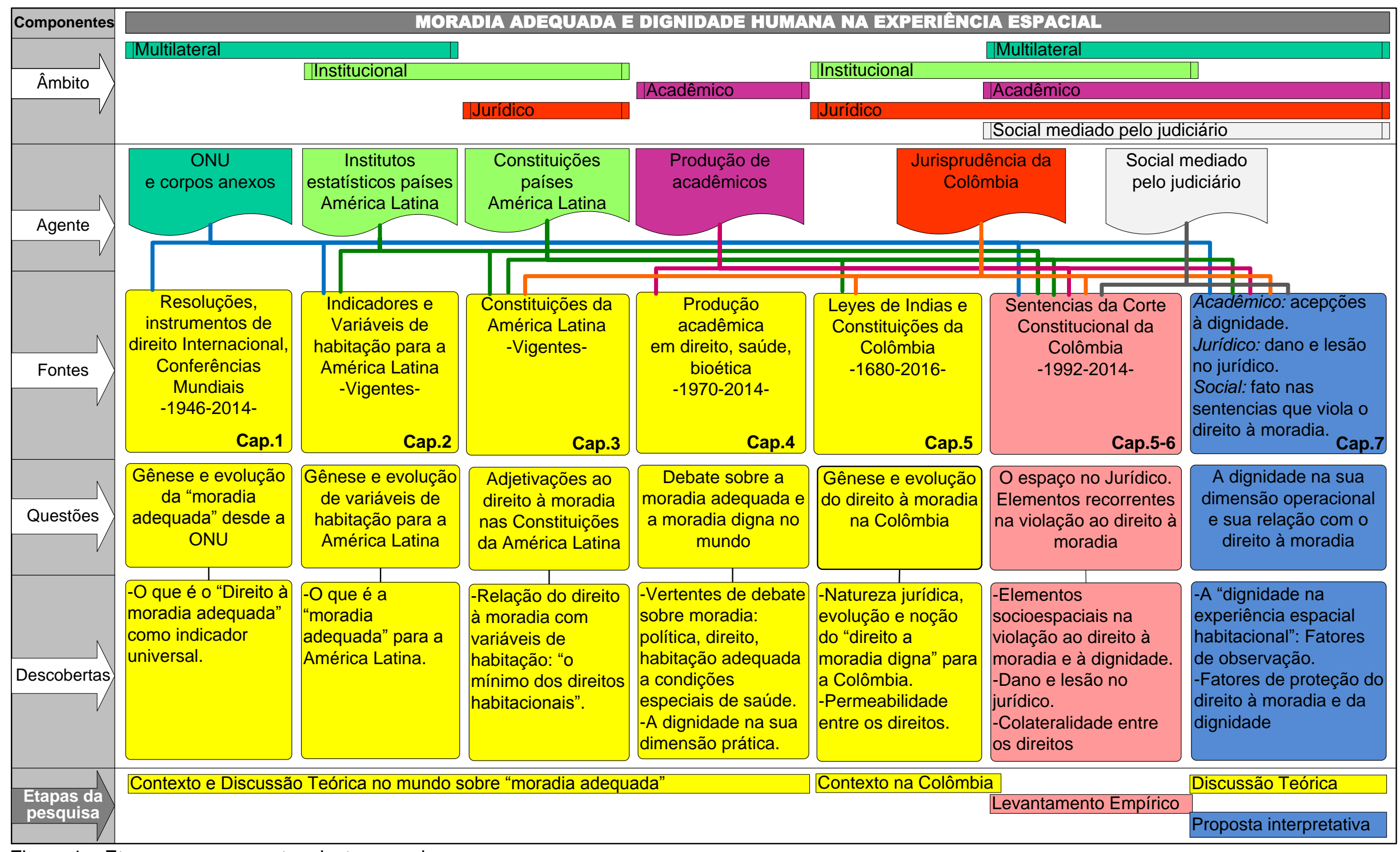

Figura 1 - Etapas e componentes desta pesquisa.

Fonte: Elaboração Própria. 


\section{Capítulo 1}

\section{A MORADIA ADEQUADA. EVOLUÇÃO NOS DOCUMENTOS DA ORGANIZAÇÃO DAS NAÇÕES UNIDAS (ONU) ${ }^{3}$}

\subsection{Introdução}

Os cenários relacionados com a política urbana utilizam indistintamente as expressões "moradia adequada" e "moradia digna". Dentre eles: i) os repórteres de agências multilaterais como a Organização das Nações Unidas (ONU) que apresentam desde os diagnósticos, o grau de moradia adequada dos países do mundo, baseados no indicador "moradia adequada" e nos sete elementos que o compõe, do Pacto Internacional de Direitos Econômicos, Sociais e Culturais (Pidesc) de 1991; ii) a política habitacional dos países da América Latina e seus indicadores de habitação, hospedados nos seus Institutos de Estatística; iii) as figuras jurídicas tais como as Sentencias de Tutela da Corte Constitucional da Colômbia, desde as quais se exibem descumprimentos ao direito à moradia, aos serviços urbanos e a um meio ambiente adequado. No uso indistinto das expressões "moradia adequada" e a "moradia digna", que são consideradas como equivalentes, mesmo não sendo conceitualmente iguais.

A Organização das Nações Unidas (ONU), como agente multilateral e institucional, é de especial relevância a respeito da provisão de moradia, pois suas resoluções, declarações e instrumentos de direito internacional recomendam critérios de políticas mandatórias para as nações integrantes. Desse modo, o foco das Nações Unidas converte-se no foco e na perspectiva dos países a respeito das políticas para a moradia, os assentamentos humanos e o meio ambiente.

O propósito deste Capítulo é pesquisar pelo papel dessa instituição na provisão de habitação, indagando pela origem e evolução do indicador institucionalizado "direito à moradia adequada" do Pidesc de 1991, o qual é aplicado pelas nações desde então,

\footnotetext{
${ }^{3}$ Este Capítulo foi apresentado em uma versão muito preliminar e em espanhol, como palestra e artigo no Congresso Internacional "Arquisur 2013". A palestra foi publicada como artigo da (MEJíA ESCALANTE, 2013) nos anais do evento, com título "Vivienda Adecuada y Derecho a la Ciudad". Congresso realizado na cidade de Córdoba, Argentina, nas datas de 25-27 de setembro de 2013.
} 
para estabelecer o seu grau de moradia adequada; assunto apresentado a partir da revisão de resoluções da ONU e instrumentos jurídicos de Direito Internacional desde 1946, ano da primeira resolução da ONU sobre moradia, até 2014 , sob a análise documental e de conteúdo.

Para essa finalidade apresentamos a abordagem metodológica aplicada para a análise dos documentos da ONU. Construímos recortes temporais entre 1946 e 2014, como forma de configurar este Capítulo, desde as variadas adjetivações à habitação encontradas na análise e que são afins à noção institucionalizada. Para terminar com uma síntese sobre a gênese e evolução da noção "moradia adequada" desde este agente multilateral.

\subsection{Documentos da ONU como instituição que dá origem à noção "moradia adequada". Abordagem metodológica}

A ONU, como instituição determinante das políticas de assentamentos humanos, é uma organização internacional, criada em 1945 por 51 países, após a segunda guerra mundial, de nações que se comprometeram a promover relações amistosas, manter a paz internacional, a segurança e o progresso social, o cumprimento dos direitos humanos e a melhoria do padrão de vida. A ONU pode tomar decisões sobre uma vasta gama de questões e fornecer um fórum para seus atuais 193 Estados-membro. Entre os seus órgãos de interesse para esta pesquisa, encontram-se a Asamblea General de las Naciones Unidas, que adiante será chamada de Assembleia, e o Consejo Económico y Social de las Naciones Unidas (ECOSOC). A Assembleia ocupa um lugar central como o principal órgão deliberativo representante da ONU para a formulação de políticas e ministra o importante papel de normalização e codificação do direito internacional. O Ecosoc atua como um fórum central para a discussão de questões econômicas e sociais internacionais, e para a formulação de recomendações dirigidas aos Estados-membro e ao sistema das Nações Unidas (NACIONES UNIDAS, 2016).

Além dos órgãos anteriores, os diversos gêneros de documentos da ONU a seguir são de alta relevância para esta pesquisa porque, além de proverem informações sobre o que constitui a moradia adequada, eles são convenções assinadas pela maioria dos Estados-membro e, entre estes, encontram-se os da América Latina. Assim temos:

i) as resoluções, as declarações e os instrumentos jurídicos internacionais de algum órgão subsidiário da ONU, adotados pela Assembleia, que contêm as informações das situações a serem melhoradas, as recomendações e os princípios de política em diversos temas; 
ii) o Yearbook das Nações Unidas, que contém as discussões sobre termos, decisões, propostas e reclamações que fundamentam os Drafts ou rascunhos das convenções, das declarações, dos tratados e dos pactos desta instituição. Os Drafts, portanto, inseridos no Yearbook, apresentam elementos significativos para esta pesquisa;

iii) Os Global Report ou relatórios globais da ONU que, nos primórdios, era o Preliminary Report on the World Social Situation, ou, em espanhol, o Informe de la Situación Social en el Mundo. Desde a década de 1990 muda o nome para Global Report on Human Settlement, e contém, em dados, o diagnóstico dos países em diversos temas;

iv) os relatórios do Relator Especial para a moradia adequada ${ }^{4}$.

A maior parte desses documentos foi localizada nos sites de documentação virtual da ONU e, em menor número, nas bibliotecas de universidades com textos online e impressos. É importante esclarecer que os idiomas oficiais da ONU são seis: árabe, chinês, espanhol, francês, inglês e russo, mas que se procurou revisar os documentos oficiais em espanhol, por ser o idioma mais aproximado do português, em termos de vocabulário e estrutura, e a língua nativa da autora desta pesquisa. Sobre a presença de alguns nomes e citações relevantes presentes nesta pesquisa, eles são apresentados no idioma dos documentos consultados ${ }^{5}$.

O contato inicial com os documentos referidos foi realizado através da recopilação, numa lista em Excel, de 8.967 resoluções publicadas no intervalo de janeiro de 1946 e dezembro de 2014. Em seguida selecionamos 500 resoluções, segundo as seguintes palavras-chave localizadas nos títulos: agua, albergue, asentamientos humanos, dignidad, derechos civiles y políticos, derechos económicos y sociales,

\footnotetext{
${ }^{4}$ Leckie apresenta a importância jurídica dos documentos mencionados. Pela natureza dos tratados, das convenções e dos pactos, se um Estado ratifica algum desses instrumentos, ele assume obrigações legais para assegurar que os direitos contidos nesses instrumentos sejam protegidos, respeitados e instituídos. Se um Estado não ratifica, só está obrigado se esse instrumento tem o status de um customary law, ou seja, a prática contínua dos Estados e da comunidade internacional de invocar elementos desse tipo de instrumentos ao longo do tempo. As declarações referem-se mais às intenções dos Estados para estabelecer determinadas políticas, em vez de constituir obrigações legais, mas têm um efeito vinculativo no direito internacional, porque é parte do que é chamado o customary law. As recomendações, casos das contidas nas resoluções da ONU, buscam oferecer critérios para legislar as práticas dos países, e, às vezes, atuam como suplemento às convenções (1992, p. 7, 17).

${ }_{5}^{5}$ Sites da ONU fonte dos documentos analisados. On-line em janeiro de 2016:

http://www.un.org/es/mainbodies/. As Nações Unidas em espanhol.

http://www.un.org/Depts/dhl/spanish/resguids/quicksp.htm. Guia de documentação da ONU. Espanhol. http://www.un.org/es/documents/ag/resga.shtml. Resoluções por período de sessões. Espanhol. http://www.un.org/documents/resga.htm. Resoluções por período de sessões. Inglês. Acesso às resoluções por período de sessões nos outros idiomas oficiais da ONU.

http://www.un.org/es/ecosoc/docs/index.shtml. Resoluções e decisões do Ecosoc. Espanhol. http://www.un.org/en/ecosoc/docs/resdec1946_2000.asp. Resoluções e decisões do Ecosoc. Inglês. http://ap.ohchr.org/documents/alldocs.aspx?doc_id=6840. Índice de documentos de direitos humanos da ONU nas suas seis línguas oficiais.
} 
energía, medio ambiente, medio humano, planificación, urbanismo, urbanización, saneamiento, vivienda; para logo encontrar outras palavras-chave no título de cada resolução, que aludem ao problema da moradia: cambio climático, cooperación técnica, derechos de los impedidos, derechos de la mujer, derechos de los niños, derechos humanos, desplazados, erradicación de la pobreza, estándar de vida, hábitat, necesidades básicas, nivel de vida, microcrédito, personas sin hogar, propiedad, refugiados, sida ${ }^{6}$. A maior parte dessas palavras têm sido tema de interesse para a ONU, desde seu início até os dias de hoje. A escolha final selecionou 200 documentos, entre resoluções e documentos anexos e complementares.

A leitura sistematizada dos documentos oficiais da ONU fundamentou-se na análise documental e de conteúdo. A análise documental é uma técnica que torna possível representar a informação de um texto em uma forma diferente do original, com base em uma classificação ou indexação temática, cujo fim é facilitar as consultas posteriores (ANDRÉU, 2002). Para a indexação temática, utilizaram-se as palavraschave referidas no parágrafo anterior, com as quais foi possível construir uma estrutura de categorias, como passo preliminar para a análise de conteúdo; a técnica de investigação que permite fazer inferências ou dar explicações aplicadas a um contexto (BARDIN, 2002; KRIPPENDORFF, 1990); com o apoio do software Atlas.Ti para análise qualitativa de dados. Esses instrumentos de análise permitiram visibilizar nos documentos da ONU as variadas adjetivações à habitação e afins à noção da moradia adequada. Com essas variadas adjetivações, por sua vez, construímos recortes temporais - como é configurado este capítulo -, os quais refletem um problema de habitação a ser enfrentado por um período, os acontecimentos da ONU mais relevantes a respeito do direito à moradia; um foco de política e programas de ação a serem aplicados nos domicílios e nos assentamentos humanos.

\section{3 "A moradia adequada". Origem e evolução}

A provisão de moradia poderia ter-se desenvolvido, segundo Craven, nos finais do século XIX e primórdios do século XX, como resposta de alguns Estados à nova situação social de bairros precários dependentes de melhores condições de saneamento, que eram resultado da urbanização e da crescente população nas cidades, pois, até então, a moradia era um assunto de provisionamento de particulares, e, assim sendo, não era matéria de regulação internacional; mas também pelos movimentos sociais e institucionais exigindo melhores condições em diversos âmbitos. Contextos em que se proveriam precondições para o conteúdo dos direitos humanos em resposta a experiências específicas ocorridas antes ou durante as

\footnotetext{
${ }^{6}$ Ver Apêndice A sobre as palavras-chave usadas nos levantamentos bibliográficos desta tese.
} 
guerras na Europa, na primeira metade do século $X X$, e na busca de criar um novo mundo "fit for democracy", utilizando as palavras desse mesmo autor (2003, p. 43).

\subsubsection{Enfrentar o "abrigo de emergência" na Europa. Diagnóstico sobre a habitação no mundo [1946 - 1960]}

A ONU inicia oficialmente o interesse pela moradia com a Resolução 53 (I) da Asamblea General (1946), intitulada Vivienda y Urbanismo, cuja urgência era a construção de moradias para enfrentar o "abrigo de emergência" em uma Europa arrasada pela guerra; além da necessidade de regulação internacional nas situações de conflitos sobre a propriedade, o abrigo nacional e internacional a refugiados, entre outros, sob a premissa de construção de habitações econômicas e rápidas.

No entanto, sem diagnósticos nem fontes de consulta, a Assembleia recomenda ao Ecosoc da ONU realizar estudos para o problema da moradia, com base em informações de diferentes países, em termos de técnicas existentes de financiamento, construção de habitação e de sistemas jurídicos e legais, para definir normas regulamentares adequadas para a sua aplicação geral (ASAMBLEA GENERAL, 1946). Para expor os dados desses diagnósticos, a Assembleia apresenta o relatório sobre a Situación Social en el Mundo para 1952 e para 1961, com dados para a maioria dos países da Europa e de alguns dos outros continentes sobre: i) as moradias disponíveis e futuras necessidades habitacionais; ii) as metodologias para a construção de programas de moradia pública; iii) o financiamento de habitação; iv) os métodos para incrementar a rapidez na construção dos domicílios; iv) os problemas sociais, econômicos e tecnológicos de planejamento de áreas urbanas e rurais; v) os conjuntos de moradia; vi) a educação dos planejadores. No item A da Resolução 830 (XXXII) do Consejo Económico y Social (1961), decide-se que a partir de 1963 será publicado este mesmo relatório global a cada dois anos ${ }^{7}$.

\footnotetext{
7 Relatórios sobre a situação social no mundo: Situación social en el mundo 1952; Situación social en el mundo 1961; Situación social en el mundo 1963; Situación social en el mundo 1967; Situación social en el mundo 1970; Situación social en el mundo 1974; Situación social en el mundo 1985; Situación social en el mundo 1989. A partir da década de 1990 serão parte de uma serie denominada Global Report on Human Settlements (Informe Global Sobre Asentamientos Humanos en espanhol), constituída pelos seguintes relatórios: An Urbanizing World 1996; Cities in a Globalizing World 2001; The Challenge of Slums 2003; Financing Urban Shelter 2005; Enhancing Urban Safety and Security Vol.1, Vol.2, Vol.3, 2007; Planning Sustainable Cities 2009; Cities and Climate Change 2011; Planning and Design for Sustainable Urban Mobility 2013. Os Global Report on Human Settlements podem ser consultados no site: http://unhabitat.org/urban-knowledge/publications/. Acesso em: jan.15 2016. Os relatórios sobre a Situación Social en el Mundo foram localizados em diversas bibliotecas de São Paulo, Brasil.
} 


\title{
1.3.2 "A moradia adequada como direito" $[1948,1966,1991]$
}

\subsubsection{O "direito a um nível de vida adequado". A moradia na Declaração Universal dos Direitos do Homem [1948-1966]}

Na Resolução 217 (III) da Asamblea General (1948) instaura-se a Declaración Universal de los Derechos del Hombre (DUDH), segundo a qual todos os seres humanos nascem com igualdade e dignidade. No seu artigo 25 mostrado no Quadro 1.1, a moradia é um componente do "direito a um nível de vida adequado" em relação com outros componentes como acesso à saúde, à alimentação, o vestuário, à assistência médica e aos serviços sociais. Sobre a necessidade de "abrigo de emergência", como os países, na década de 1950, não tinham como oferecer moradia grátis, as recomendações da ONU estabelecem o acesso à "moradia econômica e aos serviços conexos" conforme a capacidade econômica do habitante, que é definida pelo seu salário. Na mesma DUDH expressa-se sobre a necessidade de receber um salário.

\begin{abstract}
Todo mundo tem o direito ao trabalho, [...]. Todo mundo que trabalha tem direito a uma remuneração justa e satisfatória, para assegurar-lhe, bem como à sua família, uma vida em conformidade com a dignidade humana e que essa vida será completada, se necessário, por quaisquer outros meios de proteção social (ASAMBLEA GENERAL, 1948, Art.23, tradução nossa).
\end{abstract}

Essa remuneração refere-se ao salário real que, conforme a Academia de Ciências da URSS, é o expressado em meios de subsistência para o trabalhador, que deve indicar quais e quantos itens de primeira necessidade e serviços pode comprar o trabalhador com seu salário em dinheiro. A magnitude do salário real é determinada, por um lado, por um montante do salário nominal, e, por outro lado, pelos preços dos itens de consumo e serviços, pelo custo dos aluguéis e pelo volume de impostos cobrados ao trabalhador (1967, p. 116).

Craven (2003, p. 50), na sua história sobre o direito à moradia, estabelece que um dos documentos que tem ingerência na DUDH, a respeito de inserir o componente do direito ao nível de vida adequado, foi a Declaración Americana de los Derechos y Deberes del Hombre (DADH) de 1948, mencionando a habitação sob vários assuntos, mas sem se referir em explícito ao direito à moradia: 
Art.VIII. Toda persona tiene el derecho de fijar su residencia en el territorio del Estado de que es nacional, de transitar por él libremente y no abandonarlo sino por su voluntad. Art.IX. Toda persona tiene el derecho a la inviolabilidad de su domicilio. [...]. Art. XI Toda persona tiene derecho a que su salud sea preservada por medidas sanitarias y sociales, relativas a la alimentación, el vestido, la vivienda y la asistencia médica, correspondientes al nivel que permitan los recursos públicos y los de la comunidad. [...]. Art.XXIII. Toda persona tiene derecho a la propiedad privada correspondiente a las necesidades esenciales de una vida decorosa, que contribuya a mantener la dignidad de la persona y del hogar (COMISIÓN INTERAMERICANA DE DERECHOS HUMANOS, 1948, grifo nosso)

Dois aspectos interessantes sobre a anterior citação, que vinculam a habitação com assuntos mais qualitativos, ainda se podem apontar: i) o direito à inviolabilidade do domicílio, que 17 de 21 países da América Latina o incluem em suas Constituições $^{8}$ e, que por sua vez, tem relação com a privacidade e a intimidade, atos previstos apenas na Constituição da Nicarágua; e ii) a relação causa-efeito de inadequada alimentação, serviços sociais, vestuário e moradia, que pode prejudicar a saúde. Nenhum desses dois temas está incorporado na DUDH e aparecem só nas resoluções da ONU da década de 1990 e no Pidesc de 1991, mas como jurisdição da Organización Mundial de la Salud (OMS) ${ }^{9}$.

Em 1946, a OMS entra em cena como um agente institucional que, depois, será decisivo no momento de relacionar os assentamentos humanos degradados com a saúde humana, e mais perto de pensar a moradia desde a relação morador-moradia, visando efeitos na saúde física e mental. A OMS é criada com a Resolução 61 (I) da Asamblea General (1946a) e receberá, adiante, os deveres e as funções da Office International d'Hygiene Publique (OIHP), fundada no ano de 1907. A finalidade dessa primeira instituição era deliberar e controlar a quarentena em portos, para prevenir enfermidades como cólera, malária, peste, praga e para administrar outras convenções relativas à saúde ${ }^{10}$.

\footnotetext{
${ }^{8}$ Países que incluem em suas Constituições o direito à inviolabilidade do domicilio: Argentina, Art.18; Bolívia, Art.21; Brasil, Art.5; Colômbia, Art.28; Costa Rica, Art.23; Cuba, Art.56; Chile, Art. 19, 75; Equador, Art.23; Guatemala, Art.23; Honduras, Art.99; México, Art.16; Nicarágua, Art.28; Panamá, Art.26; Peru, Art.2,137; República Dominicana, Art.44, 266; Uruguai, Art.11; Venezuela, Art.47.

${ }^{9}$ A World Health Organization (WHO) por suas siglas em inglês.

10 Hoje, a Organización Mundial de la Salud (OMS) é a autoridade diretiva e coordenadora da ação de saúde no sistema da ONU; é responsável pelo papel de liderança em assuntos de saúde mundial, por definir a agenda de pesquisa em saúde, estabelecer regras, inspecionar as tendências de saúde globais, entre outros assuntos (ORGANIZACIÓN MUNDIAL DE LA SALUD, 2012).
} 


\subsubsection{A "moradia como componente do direito a um nível de vida adequado". Pacto Internacional de Direitos Econômicos, Sociais e Culturais (PIDESC) [1966]}

Em 1966 com a Resolução 2200 (XXI) da Asamblea General (1966), declarase o Pacto Internacional de Direitos Econômicos, Sociais e Culturais (PIDESC) e o Pacto Internacional de Direitos Civis e Políticos (PIDCP), porém entram em vigor apenas em 1976. No artigo 11 do Pidesc, é a primeira vez que a moradia se adjetiva como adequada, mas como recurso para alcançar o direito ao nível de vida adequado; no artigo 12 refere-se ao direito à saúde como o mais alto desfrute da saúde física e mental quando existem ótimas condições nos lugares de emprego e no meio ambiente, sem definir o que abrange o meio ambiente.

No entanto, existem várias disparidades entre o Pidesc de 1966 e o seu "Draft Covenant on Economic, Social and Cultural Rights" da General Assembly (1955). O Draft, mais preocupado por delimitar conceitos e estabelecer critérios qualitativos, o Pidesc não teve em conta as definições e variáveis do seu Draft. Neste Draft expõese que: i) o artigo 11 do Draft do Pidesc de 1966 estipularia que o "direito ao alimento adequado, ao vestuário e à moradia" seriam considerados de suficiente importância, pelos quais deveriam ficar em um artigo separado do direito ao nível de vida adequado. No entanto, no Pidesc de 1966, a moradia fica como um componente desse direito, assim, não está estipulado o direito à habitação; ii) o Pidesc não pode conter nenhuma definição de um padrão de vida adequado, baseado em que qualquer tentativa de tal definição seria restritiva em seu efeito, posição que permanece incluso no Pidesc de 1991; iii) a frase de que "toda pessoa tem direito à melhoria contínua das condições de vida" do artigo 12 do Draft e do artigo 11 do Pidesc de 1966 foi adicionada a fim de assegurar o reconhecimento da moradia como um componente do direito ao nível de vida adequado, e como um princípio a ser fornecido progressivamente; iv) o Draft, preocupado por delimitar conceitos e estabelecer critérios qualitativos para a moradia, e para os outros componentes do nível de vida tais como saúde, alimento e vestimenta, apresenta e relaciona uma definição de saúde com as variáveis desses componentes, cuja definição de saúde está contida na Constituição da OMS, no seu artigo $13^{11}$, e que não foi incluída no Pidesc de 1966. Além do mais, a introdução de uma definição de moradia adequada nesse Pidesc, foi objetada, alegando-se que tal definição é incomum nos artigos das Convenções da ONU, e, que, a referência ao "bem-estar social" (well-being no Artigo 13 do Draft) não teria por que ser invocado (GENERAL ASSEMBLY, 1955, p. 109-111).

11 Ver artigo 12 do Draft de 1955 no Quadro 1.1. Para a Constitución de la Organización Mundial de la Salud, ver (ORGANIZACIÓN MUNDIAL DE LA SALUD, 1946) 
Em virtude do anterior, o Pidesc de 1966 não fornece conteúdo associado a adequadas condições espaciais na moradia, só atende os lugares de emprego. $O$ tema sobre as condições adequadas nos domicílios e em conexão com a saúde humana surge quase três décadas depois no Pidesc de 1991, no seu elemento (iv) sobre habitabilidade, mas ainda como jurisdição da OMS com os seus princípios de "moradia saudável"12.

\subsubsection{O "direito à moradia adequada". Pacto Internacional de Direitos Econômicos, Sociais e Culturais (PIDESC) [1991]}

O Pidesc de 1991 na sua Observação № 4, 25 anos mais tarde do que o Pidesc de 1966, instaura e aplica como indicador desde essa data e em termos institucionais, o "direito à moradia adequada", além de apresentar os sete elementos que o constitui ${ }^{13}$, aplicado até hoje. Sobre o termo adequação, o mesmo Pacto traz discussão sobre sua generalidade: os sete elementos com os quais se delimita 0 direito à moradia adequada destinam-se como variáveis universais; mas esta noção, desde a expressão "adequada", também permite que cada país possa construir padrões mínimos para estes sete elementos ${ }^{14}$.

Na Observação Geral № 7 do Pidesc do ano 1997, a ONU aborda o tema das remoções e dos despejos forçados como componente do direito à moradia adequada.

\footnotetext{
12 Principios de la Vivienda Saludable da Organización Mundial de la Salud (OMS) de 1990: "La relación entre las características de la vivienda y la salud humana se plasman en seis principios fundamentales, algunos de los cuales incluyen varias subdivisiones. Esos principios se refieren a: PARTE I. 1. Protección contra enfermedades transmisibles. 2. Protección contra los traumatismos, las intoxicaciones y las enfermedades crónicas. 3. Reducción al mínimo de los factores de estrés psicológico y social. 4. Mejora del entorno habitacional. 5. Uso adecuado de la vivienda. 6. Protección de poblaciones especialmente expuestas. [...]. PARTE II. Principios relativos a la acción sanitaria. Los principios 7 a 11 tratan de las maneras en que la comunidad puede satisfacer las necesidades concernientes a los aspectos sanitarios de la vivienda, se refieren a: 7. Propaganda de la salud. 8. Políticas económicas y sociales. 9. Desarrollo, planificación y gestión. 10. Educación para la construcción y el uso de la vivienda. 11. Cooperación y autoayuda comunitaria" (ORGANIZACIÓN MUNDIAL DE LA SALUD, 1990, p. 2, 20).

${ }^{13}$ Ver Quadro 1.1 na página 42 sobre o que constitui a moradia adequada e os seus sete elementos. Para mais detalhes sobre o conteúdo desses elementos, foi realizada, no Capítulo 2, uma comparação entre cada um dos sete elementos do Pidesc e as variáveis de habitação dos países da América Latina, e, no Capítulo 6, sua relação com a noção do direito à moradia digna da jurisprudência da Colômbia. ${ }^{14}$ Parágrafo que relata a discussão sobre a expressão "adequação": "Aun cuando la adecuación viene determinada en parte por factores sociales, económicos, culturales, climatológicos, ecológicos y de otra índole, el Comité considera que, aun así, es posible identificar algunos aspectos de ese derecho [a la vivienda adecuada] que deben ser tenidos en cuenta a estos efectos en cualquier contexto determinado" (COMITE DE DERECHOS ECONÓMICOS, SOCIALES Y CULTURALES, 1991).
} 
[...] 'desalojos forzosos' se define como el hecho de hacer salir a personas, familias $y / 0$ comunidades de los hogares $y / 0$ las tierras que ocupan, en forma permanente o provisional, sin ofrecerles medios apropiados de protección legal o de otra índole ni permitirles su acceso a ellos. Sin embargo, la prohibición de los desalojos forzosos no se aplica a los desalojos forzosos efectuados legalmente y de acuerdo con las disposiciones de los Pactos Internacionales de Derechos Humanos (COMITÉ DE DERECHOS ECONÓMICOS, SOCIALES Y CULTURALES, 1997). ${ }^{15}$

No Quadro 1.1 podemos observar os Artigos relacionados à moradia na DUDH de 1948, no Draft de 1955 do Pidesc de 1966, e nos Pidesc de 1966 e de 1991.

\begin{tabular}{|c|c|c|c|}
\hline \multicolumn{4}{|c|}{$\begin{array}{l}\text { Artigos relacionados à moradia na DUDH de 1948, no Draft de } 1955 \text { do Pidesc de 1966, no } \\
\text { PIDESC de } 1966 \text { e de } 1991\end{array}$} \\
\hline $\begin{array}{r}\text { Declaraci } \\
\text { de los D } \\
\text { Homb } \\
-1\end{array}$ & $\begin{array}{r}\text { Sultural Rig } \\
-19\end{array}$ & $\begin{array}{l}\text { le } \\
\text { s, } \\
\text { s }\end{array}$ & $\begin{array}{r}\text { Pacto } \\
\text { Derec } \\
\text { Socia } \\
\text { (PI } \\
\text { Obs }\end{array}$ \\
\hline 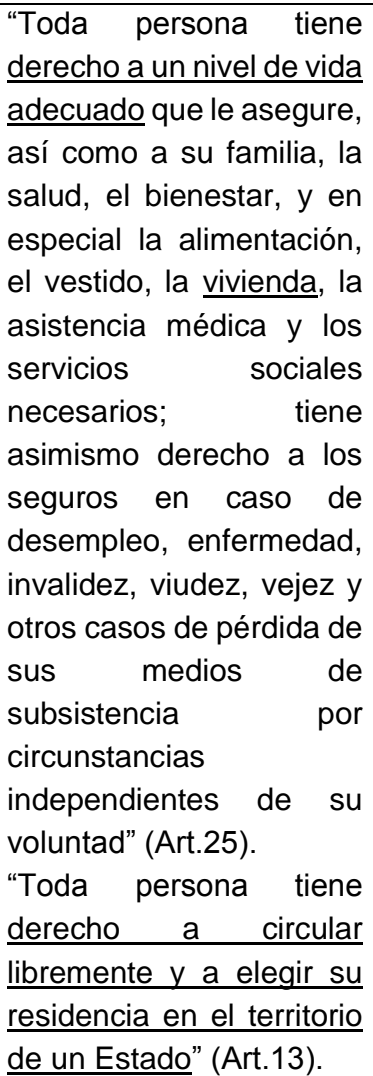 & 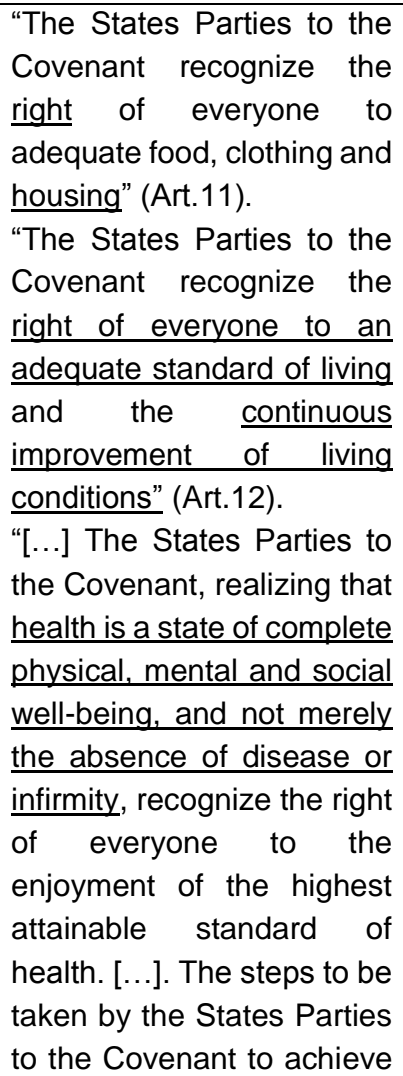 & $\begin{array}{l}\text { presente Pacto [Pide } \\
\text { reconocen el derecho } \\
\text { toda persona a un n } \\
\text { de vida adecuado para } \\
\text { y su familia, inclu } \\
\text { alimentación, vestido } \\
\text { vivienda adecuados, } \\
\text { una mejora continua } \\
\text { las condiciones } \\
\text { existencia" (Art.11). "L } \\
\text { Estados Partes en } \\
\text { presente } \\
\text { reconocen el derecho } \\
\text { toda persona al disfr } \\
\text { del más alto nivel posi } \\
\text { de salud física y men } \\
\text { [...]; el mejoramiento } \\
\text { todos sus aspectos de } \\
\text { higiene del trabajo y } \\
\text { medio ambiente; [. } \\
\text { (Art.12). }\end{array}$ & $\begin{array}{l}\text { "La vivienda adecuada } \\
\text { significa disponer de un } \\
\text { lugar donde poderse aislar } \\
\text { si se desea, } \underline{\text { espacio }} \\
\text { adecuado, seguridad } \\
\text { adecuada, iluminación y } \\
\text { ventilación adecuadas, una } \\
\text { infraestructura básica } \\
\text { adecuada y una situación } \\
\text { adecuada en relación con } \\
\text { el trabajo y los servicios } \\
\text { básicos, todo ello a un } \\
\text { costo razonable" } \\
\text { [Los Siete Elementos son:] } \\
\text { (i) Seguridad jurídica de la } \\
\text { tenencia; } \\
\text { (ii) disponibilidad de } \\
\text { servicios, materiales, } \\
\text { facilidades } \\
\text { infraestructura; } \\
\text { (iii) gastos soportables; } \\
\text { (iv) habitabilidad; } \\
\text { (v) asequibilidad; } \\
\text { (vi) lugar; }\end{array}$ \\
\hline
\end{tabular}

${ }^{15}$ Para mais detalhe ver: Observación general № 7 (1997). El derecho a una vivienda adecuada (párrafo 1 del artículo 11 del Pacto): los desalojos forzosos - Comité de Derechos Económicos, Sociales y Culturales- do (COMITÉ DE DERECHOS ECONÓMICOS, SOCIALES Y CULTURALES, 1997). 


\begin{tabular}{|l|l|l|l|}
\hline \multicolumn{5}{|c|}{ Artigos relacionados à moradia na DUDH de 1948, no Draft de 1955 do Pidesc de 1966, no } \\
PIDESC de 1966 e de 1991
\end{tabular}

Quadro 1.1 - Artigos relacionados à moradia na DUDH de 1948, no Draft de 1955 do Pidesc de 1966, no PIDESC de 1966 e de 1991

Fonte: Elaboração própria baseada nas fontes citadas.

Obs.: O sublinhado é nosso, para ressaltar aspectos relacionados à moradia.

O elemento (iv) habitabilidade do Pidesc de 1991, refere que, devem ser atendidos os Princípios da Moradia Saudável da OMS de 1991. Ver Nota de Rodapé n²12, para esses princípios.

\subsubsection{A "moradia econômica e os serviços comunitários conexos". Assistência técnica, financiamento externo, mutirão e outras formas de associação [1952-1970]}

Em 1952 é a primeira vez com a Resolução 537 (VI) que os domicílios associam-se com o adjetivo do "adequado", desde o enunciado "escassez de moradia adequada". Mas não se considera que o problema seja que a moradia é inadequada, senão que é uma inadequação ou é inaceitável a escassez de domicílios para a população que migra dos campos para as cidades, assim como para quem não tem teto, como consequência das guerras na Europa, entre outros motivos (ASAMBLEA GENERAL, 1952).

16 Uma moradia adequada compreende "[...] intimidade suficiente, espaço adequado, segurança adequada, iluminação e ventilação suficientes, infraestruturas básicas adequadas e localização adequada relativamente ao local de trabalho e aos serviços essenciais - tudo isto a um custo razoável para os beneficiários". Os sete elementos do Direito à Moradia Adequada do Pidesc de $1991 \mathrm{em}$ português são: (i) segurança da posse; (ii) disponibilidade de serviços, materiais, instalações e infraestrutura; (iii) economicidade; (iv) habitabilidade; (v) acessibilidade [econômica]; (vi) localização [adequada]; (vii) adequação cultural. (SECRETARIA DE DIREITOS HUMANOS DA PRESIDÊNCIA DA REPÚBLICA - SDH/PR, 2013). 
Essa inadequação, conforme essa resolução, poderia ser mitigada proporcionando aos governos informação sobre técnicas de construção que permitissem aumentar a produtividade na indústria da construção, diminuindo o custo da moradia; reduzindo o preço dos materiais a partir da tipificação e a pré-fabricação; proporcionando bolsas de estudo para técnicos; oferecendo assistência técnica para os governos; fornecendo apoio em novos métodos práticos para o financiamento dos programas de construção de habitação; e provendo aos governos de apoio econômico da banca internacional.

Em fins de 1950 com a escassez de domicílios, acrescenta-se o problema do acesso à habitação. Assim, a discussão volta-se para o "acesso à moradia econômica e aos serviços comunitários conexos", mas, considerando-se um salário real para seu acesso. Em paralelo, a dinâmica da urbanização torna-se um assunto de vital importância na década de 1960, até ter resoluções direcionadas a esse tema. $\mathrm{Na}$ Resolução 1.676 (XVI) da Asamblea General (1961), a urbanização se compreende como um processo configurado pela migração de pessoas das áreas rurais para as cidades, visibilizando situações como a insuficiência de serviços urbanos para o atendimento dos habitantes e a dificuldade das populações rurais para se adaptar à vida urbana, além da escassez de moradia. Porém neste documento, considera-se que esse processo de migração, em algum momento não muito distante, terminaria, o qual continua à data de 2016.

As resoluções nesse recorte temporal recomendam que os governos determinem programas para que os países cresçam economicamente, com iniciativas que incluam moradia e serviços urbanos conexos, compatíveis com os Objetivos do Decênio. Notese que a ONU não buscava atender às condições qualitativas da moradia e dos serviços, mas sim à quantidade de domicílios para cobrir as famílias sem teto, porém, o acesso à moradia econômica era a partir de seu pagamento.

\subsubsection{Desde "sem fome no mundo" até "cidades sem bairros de tugúrios". Decênios para o Desenvolvimento e a Declaração do Milênio [1960-2000]}

Nos primórdios de 1960, a preocupação emergente, em matéria de desenvolvimento, era lutar contra a fome no mundo. A Organización de las Naciones Unidas para la Agricultura y la Alimentación (FAO) liderou os esforços internacionais para apoiar os países nessa situação, com o lançamento, em julho de 1960, da campanha mundial contra a fome. Reconhecendo que o problema não se reduzia apenas à luta contra a fome, na Resolução $1.710(\mathrm{XVI})$, proclama-se o Decenio de las Naciones Unidas para el Desarrollo (1961-1970), cujo objetivo global estabelece que cada país insuficientemente desenvolvido possa alcançar um aumento considerável no ritmo de crescimento, fixando cada país seu próprio objetivo, mas tendo em vista uma taxa mínima anual de crescimento de $5 \%$ no ingresso global anual ao final do decênio (ASAMBLEA GENERAL, 1961a). 
Jackson expressa que, apesar dos avanços com o Primeiro Decênio, o Secretário Geral das Nações Unidas admite em meados desse período que ocorreu pouco progresso e os objetivos ainda permaneciam distantes (2007). Porquanto, a Asamblea General (1970), na Resolução 2.626 (XXV), proclama o Segundo Decenio de las Naciones Unidas para el Desarrollo (1971-1980). No entanto, e segundo Jackson, as atividades dessa segunda década para o desenvolvimento são severamente afetadas com a reviravolta causada pelo colapso da economia nos anos 1970 na Europa. Para a situação mencionada, a Asamblea General (1979) em sua Resolução 33/193, aprova a nova estratégia do Tercer Decenio de las Naciones Unidas para el Desarrollo (1981-1990).

Antonucci revê o contexto destes Decênios para a década de 1980 e 1990 desde o obrar do Banco Mundial, e afirma que esse impôs programas de ajustes estruturais aos países em desenvolvimento, o que resultou em impactos negativos sobre 0 emprego, os preços dos alimentos e o custo da habitação, e como consequência, a maior parte dos países em desenvolvimento teve baixa capacidade de atendimento de demandas habitacionais (ANTONUCCI, BENATTI, et al., 2010, p. 145).

Ainda que os programas estipulados desde o primeiro decênio tenham sido desenvolvidos de diversas formas em variados países, continuam, entre outros, os problemas de acesso e habitabilidade na moradia, e as condições de vida nos países em desenvolvimento apresentam deterioração na década de 1990. Em consequência, proclama-se o Cuarto Decenio de las Naciones Unidas para el Desarrollo (1991-2000), além do Primer Decenio de las Naciones Unidas para la Erradicación de la Pobreza (1997-2006) na [Resolução 52/193] da Asamblea General (1998), para dar resposta às condições deploráveis das cidades, derivadas das novas circunstâncias econômicas mundiais.

Para o ano 2000, ainda persiste a degradação de amplas áreas residenciais no mundo, apesar dos objetivos estipulados na proclamação dos decênios. Na busca de novos objetivos universais, que pudessem ser aplicados localmente, instaura-se a Declaración del Milenio (ODM), com objetivos para o ano 2020. Jackson afirma que os ODM não se instituem como parte de um novo programa, mas que, aplicando um enfoque holístico, a ONU tenta combinar variadas atividades designadas para os decênios, que ficavam como dívida, para concentrar esforços e fazer frente à pobreza e ao baixo desenvolvimento econômico e social (2007). Antonucci expressa que os ODM representam um marco para a consolidação progressiva da questão urbana no contexto mundial (2010, p. 13).

A Declaração do Milênio (ODM) da Asamblea General (2000; 2000a) [Resolução 54/282; 55/2] busca, para o ano 2020, melhorar significativamente a vida de pelo 
menos 100 milhões de pessoas que habitam em assentamentos precários. Assim, o Objetivo (7) busca a meta de "cidades sem assentamentos precários", com suporte na definição de UN-Habitat que determina uma "família em assentamento precário" quando ela carece de uma ou mais das seguintes condições: i) moradia com materiais duráveis, como proteção às condições climáticas e externas; ii) moradia com não mais de duas pessoas por cômodo; iii) acesso à água potável; iv) com saneamento e sanitário privado, ou coletivo, para um número razoável de pessoas; e v) segurança legal da posse (UN-HABITAT, 2003). ${ }^{17}$. A instauração dessas variáveis, vão no caminho de construir instrumentos operacionais para que a população alvo, que são as pessoas que moram em assentamentos precários, possam-se beneficiar de programas específicos nacionais.

\subsubsection{A "moradia como um componente do nível de vida", enfoque paralelo [Décadas 1960 e 1970]}

A problemática para a década de 1960 apresenta-se como a moradia econômica. Nas resoluções da ONU, até esse período, em que se ditam as recomendações, não há associação alguma à habitação como componente do nível de vida adequado ou como direito, e também não há referência às condições de vida. Mesmo nesse período, a ONU não pensa a moradia numa relação com o usuário que a habita. As condições qualitativas de vida e de habitação foram abordadas pela Organización Internacional del Trabajo (OIT), compiladas a modo de critérios na Recomendación sobre la vivienda de los trabajadores número 115 (OIT, 1961), cujo objetivo foi revisar as condições espaciais das moradias ou de lugares para dormir, que eram entregues ao trabalhador, como parte do salário; além de revisar as qualidades espaciais nos empregos. Aliás, consideramos que esse é um dos instrumentos internacionais mais detalhados, desde então até o 2016, sobre o que se denomina, em espanhol o "alojamiento adecuado y decoroso y un medio ambiente apropiado"; e em inglês o "adequate and decent housing accommodation and a suitable living environment"18.

A razão para criar um guia para as condições de habitabilidade nos lugares de emprego, nas fases do desenvolvimento do capitalismo, era o sistema de pagamento em espécie que, segundo a Academia de Ciencias de la URSS, consistia em que ao

17 Os oito Objetivos dos ODM são: 1) acabar com a fome; 2) promover uma educação básica de qualidade para todos; 3) a igualdade entre o homem e a mulher; 4) reduzir a mortalidade infantil; 5) melhorar a saúde das gestantes; 6) combater novas pandemias, como a Aids e a malária; 7) garantir a sustentabilidade do meio ambiente, objetivo que abrange o concernente à moradia adequada; 8 ) apoio à livre associação (ASAMBLEA GENERAL, 2000).

18 Para mais detalhes sobre o instrumento "Recomendación sobre la Vivienda de los Trabajadores Número 115" de 1961, ver (OIT, 1961). 
trabalhador dava-se um lugar para morar, a alimentação e algum dinheiro, e, assim, o capitalista o explorava como vendedor de força de trabalho e como consumidor (1967, p. 115). Em virtude disso, as instituições como a OIT, a OMS e a FAO buscavam estabelecer critérios a respeito das condições ambientais, espaciais, de saúde e de nutrição, nas áreas de trabalho e nos alojamentos oferecidos como parte do pagamento, para que o trabalhador pudesse desempenhar o seu ofício.

A Recomendação sobre a moradia para trabalhadores n¹15 da OIT (1961), que é definida como um guia para as políticas de habitação, revê a relação morador-espaço e apresenta critérios a respeito dos seguintes temas: objetivos de políticas nacionais; responsabilidade das autoridades públicas; características das moradias proporcionadas pelos empregadores, assim como para os serviços conexos e para os lugares de emprego; financiamento; medidas para aumentar a eficiência na construção de domicílios; construção como fonte de emprego; política de aluguel, urbanismo e planificação rural; critérios para definir um sistema de componentes urbanos composto por facilidade de transporte e empregos próximos dos serviços urbanos, além de se rever os níveis de poluição e topográfico das áreas de construção, focado na recomendação de fatores ambientais que possam incidir na qualidade dos assentamentos humanos ${ }^{19}$.

Na mesma direção da Recomendação 115, o Secretário Geral das Nações Unidas, também com interesse em revisar a relação morador-espaço, com a cooperação da OIT e outros organismos especializados da ONU, fundamentados em um primeiro relatório de peritos orientados pelo Economic and Social Council (1954), discorre sobre as necessidades básicas do indivíduo, com o interesse de estipular indicadores sociais, de moradia, de educação e de nutrição, assim como instaurar indicadores para medir o nível de vida. Desse modo, os peritos estavam voltados a constituir:

[...] 'un pequeño grupo de expertos encargado de preparar un informe sobre los métodos más satisfactorios para definir y evaluar el nivel de vida y sus variaciones en los diversos países, teniendo en cuenta la conveniencia de permitir comparaciones en el plano internacional'. [...] El Comité llegó a la conclusión de que el modo más satisfactorio de medir los niveles de vida en el orden internacional sería proceder a la medición de aspectos 0 partes claramente delimitados de las condiciones generales de vida que pudieran representarse cuantitativamente [...]. Esferas separadas tales como la salud, la nutrición, la vivienda, las condiciones de empleo y la educación se consideraron como

\footnotetext{
${ }^{19}$ A OIT estipula que a Recomendação 115 se aplica tanto para trabalhadores manuais e não manuais,
} quanto para os trabalhadores independentes, idosos, aposentados e os sem educação. 
'componentes' del nivel de vida, y se propuso expresar estos componentes por medio de medidas o 'indicadores' estadísticos concretos, teniendo en cuenta la disponibilidad y comparabilidad internacional de los datos (NACIONES UNIDAS, 1961, p. 1).

Essa pesquisa de organismos especialistas da ONU fornece o documento intitulado Definición y Medición Internacional del Nivel de Vida, que substituiu o textobase de 1954 do Economic and Social Council, caracterizado como um guia básico para os governos, as instituições de pesquisa e similares, com interesse na padronização e avaliação do nível de vida. O documento de 1961 é notável, já que, segundo a resenha das Nações Unidas sobre o texto, foi o primeiro impresso a encaminhar as preocupações internacionais a respeito de aspectos comparáveis sobre o nível de vida entre os países. Além disso, nele sugere-se uma definição de nível de vida adequado, seus componentes e os indicadores prioritários e complementares que os compõem, sendo a moradia um destes componentes. Esses indicadores são os que se aplicam, desde essa data, para avaliar as condições de habitação no mundo ${ }^{20}$; e os quais abrangem variáveis, configuradas por mínimos estabelecidos e demonstrados, que em caso de não serem respeitados, podem comprometer a saúde do homem. Estes indicadores são:

1) Porcentaje de la población que habita en 'viviendas'; 2) Porcentaje de viviendas ocupadas en las que haya tres o más personas por habitación; 3) Porcentaje de viviendas ocupadas que tienen agua corriente dentro de la vivienda o fuera de ella pero a no más de cien metros; 4) Porcentaje de viviendas ocupadas con excusado. [...], se recomiendan los siguientes indicadores suplementarios: 1) Porcentaje de la población que ocupa viviendas que no reúne las debidas condiciones de habitabilidad clasificadas como 'rústicas', 'improvisadas' y 'no aptas para ser habitadas', o que carecen de todo abrigo; 2) Promedio de personas por habitación (sólo para las viviendas ocupadas); 3) Porcentaje de viviendas ocupadas dotadas de retretes inodoros (urbanas); 4) Porcentaje de viviendas ocupadas provistas de otro tipo de retrete (NACIONES UNIDAS, 1961, p. 13).

20 O documento de 1961 é um guia que indica os padrões mínimos para a medição do nível de vida nos seguintes componentes: saúde; consumo de alimentos e nutrição; educação; emprego e condições de emprego; moradia. O grupo de especialistas desse guía está composto pela ONU; Oficina Internacional del Trabajo (OIT); Organización de las Naciones Unidas para la Agricultura y la Alimentación (FAO); Organización de las Naciones Unidas para la Educación, la Ciencia y la Cultura (Unesco); Organización Mundial de la Salud (OMS). 
Estabelecidos os componentes do nível de vida no documento da ONU de 1961: saúde, nutrição, moradia, condições de emprego e educação, foi imperativo fixar uma diferença entre nível de vida, standard e norma. Assim, institui-se, nesse documento o "nível de vida" como as condições atuais nas quais vive a população; "standard" como as condições consideradas adequadas para uma ou outra população; "norma" a que se refere à condição desejável definida por e para propósitos particulares (NACIONES UNIDAS, 1961, p. 1, tradução nossa). Definições que já haviam sido propostas de forma mais geral nos documentos do Economic and Social Council $(1956 ; 1954)$.

Sobre a padronização das condições na moradia, o texto enfatiza que sempre deverão ser completadas as estatísticas com material descritivo, fundamentado em informação regional, interpretando o conceito local de moradia, descrevendo as instalações segundo cada cultura e avaliando o nível e os serviços de cada comunidade (NACIONES UNIDAS, 1961, p. 13). Para o 2016, as variáveis contidas nesse guia de 1961 são as consideradas para indicadores de condições de vida.

Ainda que os indicadores prioritários e complementares fornecidos no documento de 1961 (anterior citação textual) comecem a ser aplicados e revelados desde 1967 em forma de dados nos Relatórios sobre a Situação Social do Mundo ${ }^{21}$, que foram usados na década de 1970 desde uma política de "Necessidades Básicas", e que sua origem tenha sido a preocupação pelas condições de vida nos lugares de emprego e nas moradias dadas como parte do salário aos trabalhadores, esse conteúdo das condições de vida é um enfoque paralelo nas décadas de 1960 e 1970, às políticas de habitação da $\mathrm{ONU}$, refletido nos documentos anexos e complementares, mas não nas resoluções, que são as que realmente ditam as diretrizes gerais e os enfoques a serem seguidos pelos países integrantes.

\subsubsection{De "Necessidades Básicas" ao Indicador de "Necessidades Básicas Insatisfeitas (NBI)" [1970-1990]}

The World Employment Conference de 1976 propõe a abordagem de uma política de necessidades básicas, visando a efetivação de um mínimo standard de vida, antes do final do século XX e na busca que os países a adotassem (ILO, 1976, p. 6). Para isso, uma recomendação que emerge dos documentos da ILO foi construir "um corpo de conhecimento no campo das necessidades básicas, e assuntos técnicos concernentes para a aplicação de uma política de Basic Needs Approach to Development (BNA), em específico para a América Latina e O Caribe. [...]. Na direção

\footnotetext{
${ }^{21}$ Sobre os títulos dos Informes Sobre a Situação Social no Mundo da ONU, ver Nota de Rodapé №.7.
} 
de formular políticas operacionais para o programa de BNA nessa região" (OIT, 1979, p. 1, tradução nossa). Assim, buscou-se estabelecer uma política de assentamentos humanos para os "países americanos em desenvolvimento", baseada no conceito de necessidades básicas que, logo na década de 1980, é chamada de Indicador de Necesidades Básicas Insatisfechas para América Latina y El Caribe (NBI) ${ }^{22}$, definindo as necessidades básicas como:

the minimum standard of living which a society should set for the poorest groups of its people. The satisfaction of basic needs means meeting the minimum requirements of a family for personal consumption: food, shelter, clothing; it implies access to essential services, such as safe drinking-water, sanitation, transport, health and education; [...]. Implies that each person available for and willing to work should have an adequately remunerated job. It should further imply the satisfaction of needs of a more qualitative nature: a healthy, humane and satisfying environment, and popular participation in the making of decisions that affect the lives and livelihood of the people and individual freedoms (ILO, 1976, p. 7, grifo nosso).

Mas, para que um grupo familiar tenha acesso ao mínimo consumo requerido, a respeito de alimento, vestuário, serviços básicos e teto,

a política de necessidades sugerida implica uma expansão dos objetivos do World Employment Programme. Esse programa tem-se focado na criação de mais produtivos e remunerativos empregos. Esse é um meio essencial para atingir os objetivos da política de necessidades básicas. [...]. Isso implica que cada pessoa disponível e disposta a trabalhar, deve ter um trabalho com remuneração adequada (ILO, 1976, p. 7, tradução nossa).

\subsubsection{De problemas no "meio humano" a problemas no "meio ambiente" [1968, 1972, 1992]}

No final dos anos 1960, a degradação ambiental e o crescimento da população urbana tornaram-se objeto de discussões internacionais (ANTONUCCI, BENATTI, et al., 2010, p. 23). Assim, quase uma década após da edição do documento guia das Naciones Unidas (1961) sobre os componentes do nível de vida adequado, a ONU foca de novo a atenção na relação do homem com o espaço em que ele mora; mas na perspectiva sobre como as formas de habitar e a urbanização

\footnotetext{
${ }^{22} \mathrm{O}$ Capítulo 2 faz referência mais em detalhe sobre o NBI.
} 
acelerada nos conglomerados urbanos em crescimento, estão transformando e afetando o "meio humano". Com a Resolução 2.398 (XXIII) da Asamblea General (1968), intitulada Problemas del Medio Humano, aceitam-se que as transformações do meio ambiente - a contaminação do ar e das águas, a erosão, os dejetos, o barulho, os efeitos secundários dos produtos biocidas, têm efeitos sobre a saúde do homem, o seu bem-estar físico e social.

A discussão desses assuntos, por sua vez, contribui para que nesta resolução tenhase expresso a necessidade de uma Conferência Mundial sobre o Meio Humano, realizada em $1972^{23}$ em Estocolmo, cujo objetivo geral foi instaurar uma visão e princípios comuns para inspirar e guiar os povos do mundo na preservação e melhoria do meio humano (UNITED NATIONS, 1972). A noção de "meio humano", aliás, é substituída pela do "meio ambiente" na Conferência das Nações Unidas sobre Meio Ambiente e Desenvolvimento (Cnumad) de $1992^{24}$, na qual 172 governos aprovaram três importantes acordos que regeriam o trabalho futuro sobre o meio ambiente: i) Agenda 21 (1972), um plano global de ação para promover o desenvolvimento sustentável; ii) a Declaração do Rio de Janeiro sobre o Meio Ambiente e Desenvolvimento (1992), contendo um conjunto de princípios que definem os direitos e as obrigações dos Estados-integrantes; e iii) uma declaração de princípios sobre florestas, produto da Declaração do Rio-92 (NACIONES UNIDAS, 2013).

Os três acordos não têm um princípio explícito para a moradia. No que concerne aos assentamentos humanos, as duas conferências focaram-se no controle dos processos de utilização dos recursos, assim como na gestão dos recursos básicos como água, energia e saneamento, e dos resíduos gerados pelos conglomerados humanos. Doravante, a partir da década de 1980, e depois da Conferência mundial Hábitat I de 1976, a Assembleia estabelecerá resoluções por separado para o problema dos assentamentos humanos e meio ambiente; antes de meados da década de 1970, as questões sobre assentamentos humanos não apareciam explícitas nas resoluções da ONU.

\subsection{8 "Assentamentos humanos". Conferência mundial Hábitat I [1976], Hábitat II [1996], Hábitat III [2016]}

O que hoje é conhecido como o Programa de las Naciones Unidas para los Asentamientos Humanos, começou como a Fundação Habitat, órgão relacionado com

${ }^{23}$ Conferencia de las Naciones Unidas sobre el Medio Humano, em espanhol. United Nations Conference on the Human Environment, em inglês.

24 Conferencia de las Naciones Unidas sobre Medio Ambiente y Desarrollo - Cumbre para la Tierra (Cnumad), em espanhol. United Nations Conference on Environment and Development, em inglês. 
o Programa de las Naciones Unidas para el Medio Ambiente (PNUMA). Era o início da década de 1970. Em 1976 teve lugar em Vancouver, no Canadá, a Conferência das Nações Unidas sobre Assentamentos Humanos (Habitat I). Nesse caso, a Fundação Habitat mudou seu nome para o Centro de las Naciones Unidas para los Asentamientos Humanos (CNUAH), com sede em Nairóbi, Quênia. Vinte anos mais tarde, em 1996, foi a Segunda Conferência das Nações Unidas para os Assentamentos Humanos (Habitat II), em Istambul, Turquia, na que se adoptou a Agenda Habitat e a Declaração de Istambul, e desde as quais os governos comprometeram-se com os objetivos de alcançar a moradia adequada $\mathrm{e}$ assentamentos humanos sustentáveis para todos (NACIONES UNIDAS, 2015). A Habitat III, nomeada como a Terceira Conferência das Nações Unidas sobre Habitação e Desenvolvimento Urbano Sustentável, terá lugar em Quito, Equador, no mês de outubro de 2016.

Na década de 1970, os movimentos ambientalistas promoviam uma "agenda verde" que denunciava a urbanização descontrolada e solicitava um ideal de vida rural, pelo que se culpava à atividade humana pela maior parte dos problemas do meio humano, contexto que foi influxo nas discussões na Habitat I (ANTONUCCI, BENATTI, et al., 2010, p. 25). As diversas declarações do Secretário-Geral do Hábitat I - Enrique Peñalosa -, quem afirmava que a moradia precária era fruto de duas situações: um crescimento urbano mundial caótico, o que gerava graves desequilíbrios; e que as ações, organizadas para atender a necessidade das comunidades locais, estavam desarticuladas de um planejamento global; ambos os posicionamentos, conforme Antonucci, já deixavam entrever o foco dos documentos resultantes dessa Conferência: "a explícita valorização do planejamento em escala nacional sob a égide de um Estado regulador, dispondo de aparatos institucionais consolidados" (p. 31). As Habitat I e II inserem-se em um contexto de "problemas mundiais emergentes, reflexos da intensa migração rural-urbana da década de 1970 e dos desequilíbrios intraurbanos que se intensificam a partir do final da década de 1980 em todos os centros urbanos mundiais" (p. 13).

$\mathrm{Na}$ Habitat II, os governos destacaram sete principais prioridades a serem solucionadas: i) os padrões de consumo e produção, particularmente nos países industrializados; ii) a mudança demográfica insustentável; iii) a população sem moradia; iv) o desemprego; v) a falta de infraestrutura e serviços básicos; vi) a insegurança e violência; e vii) o aumento da vulnerabilidade aos desastres naturais. $\mathrm{Na}$ Hábitat II, observamos que as políticas sobre moradia têm a ver com as prioridades iii, v e vi; enquanto que as políticas para assentamentos humanos referem-se mais às prioridades $\mathrm{i}$, ii, iv e vii.

O assunto da moradia adequada está presente nas conferências da Hábitat I e II quando estabelecem compromissos para os governos, os quais deveriam 
proporcionar para todos os seus cidadãos o seguinte: velar pela segurança da posse e a igualdade no acesso à terra, oferecer acesso à água potável e saneamento básico; promover o acesso e sistemas de financiamento para a moradia; implantar medidas de acesso físico e econômico às pessoas com deficiência; aumentar e manter a oferta de habitação em condições adequadas. A respeito dos assentamentos humanos, a Hábitat I e, em considerável medida, a Hábitat II estão interessadas na gestão e sustentabilidade dos recursos, na disponibilidade de redes de serviços básicos e dos serviços urbanos, além da disponibilidade de transporte racionalmente ambiental.

O que mostra a anterior descrição sobre as Hábitats I e ll é que enquanto os critérios sobre a moradia focam nas condições de habitabilidade no domicílio e seu entorno, desde o acesso e a qualidade dos serviços conexos; os critérios de política dos assentamentos têm a ver mais com cobertura e gestão das condições sanitárias dos assentamentos, sem esquecer os critérios demográficos e o cuidado com os recursos do meio ambiente. Assim, nestas conferências, a habitação é apenas mais um componente entre outros, ainda que constituam um capítulo para a exposição de problemas, recomendações, critérios de política e de compromissos das nações, relativos à moradia adequada.

\subsection{A "Moradia Adequada" desde as Nações Unidas como agente multilateral. Síntese}

Referente à moradia, as instituições e os programas mundiais da ONU têm construído eventos significativos que refletem a evolução do direito à moradia, como podemos observar no Quadro 1.2.

\begin{tabular}{|l|l|}
\hline Ano & $\begin{array}{l}\text { Eventos mais significativos da ONU que relatam o Direito à Moradia Adequada e } \\
\text { assuntos conexos }\end{array}$ \\
\hline 1946 & Primeira resolução da ONU sobre moradia: "Vivienda y Urbanismo". Resolução 53(1). \\
\hline 1946 & $\begin{array}{l}\text { Primeira resolução da ONU sobre refugiados e deslocados: "Refugiados y personas desalojadas". } \\
\text { Resolução 62(1). }\end{array}$ \\
\hline 1947 & Entrada em vigor da Constituição da Organización Mundial de la Salud (OMS). Resolução 131(2). \\
\hline 1948 & $\begin{array}{l}\text { Universal Declaration of Human Rights (UDHR). Declaração Universal dos Direitos do Homem } \\
\text { (DUDH). }\end{array}$ \\
\hline 1952 & Primeira resolução da ONU sobre "Vivienda, Urbanismo y Planificación Rural". Resolução 537(VI). \\
\hline 1959 & Primeira resolução da ONU sobre "Vivienda económica". Resolução 1393(XIV). \\
\hline 1959 & $\begin{array}{l}\text { Declaration of the Rights of the Child. Declaração dos Direitos das Crianças (Direito a uma moradia. } \\
\text { Princípio 10). Documento da ONU no A/4354. }\end{array}$ \\
\hline 1960 & $\begin{array}{l}\text { Primeira resolução da ONU sobre "Vivienda económica y servicios comunales conexos". Resolução } \\
1508(X V) .\end{array}$ \\
\hline 1961 & Documento guía da ONU “Definición y medición internacional del nivel de vida. Guia provisional". \\
\hline 1961 & $\begin{array}{l}\text { "R.115 - Recomendación sobre la vivienda de los trabajadores" da Organización Internacional del } \\
\text { Trabajo (OIT). }\end{array}$ \\
\hline 1966 & $\begin{array}{l}\text { International Covenant on Economic, Social and Cultural Rights (ICESCR). Pacto Internacional de } \\
\text { Direitos Econômicos, Sociais e Culturais (PIDESC). }\end{array}$ \\
\hline
\end{tabular}




\begin{tabular}{|c|c|}
\hline Ano & $\begin{array}{l}\text { Eventos mais significativos da ONU que relatam o Direito à Moradia Adequada e } \\
\text { assuntos conexos }\end{array}$ \\
\hline 1968 & Resolução da ONU sobre "Problemas del medio humano". Resolução 2398(XXIII). \\
\hline 1972 & $\begin{array}{l}\text { United Nations Conference On The Human Environment. } \\
\text { Conferência das Nações Unidas Sobre o Meio Humano. Estocolmo, Suécia. }\end{array}$ \\
\hline 1974 & $\begin{array}{l}\text { "Establecimiento de la Fundación de las Naciones Unidas para el Hábitat y los Asentamientos } \\
\text { Humanos". Resolução } 3327(\mathrm{XIX}) \text {. }\end{array}$ \\
\hline 1976 & $\begin{array}{l}\text { First United Nations Conference on Human Settlement (Habitat I). } \\
\text { Primeira Conferência sobre Assentamentos Humanos (Habitat I). Vancouver, Canadá. }\end{array}$ \\
\hline 1987 & $\begin{array}{l}\text { Declarado como o "Año Internacional de la Vivienda para las Personas sin Hogar" na Resolução } \\
37 / 221 \text { de } 1982 \text {. }\end{array}$ \\
\hline 1990 & General Discussion on the Right to Housing. Documento da ONU no E/C.12/1990/3. \\
\hline 1990 & $\begin{array}{l}\text { Declarada primeira violação ao direito à moradia: República Dominicana. Documento da ONU no } \\
\text { E/C.12/1990/8. }\end{array}$ \\
\hline 1990 & $\begin{array}{l}\text { "El respeto del derecho de toda persona a la propiedad individual y colectiva y su contribución al } \\
\text { desarrollo económico y social de los estados". Resolução } 45 / 98 \text {. }\end{array}$ \\
\hline 1990 & "Principios de la Vivienda Saludable" da Organización Mundial de la Salud (OMS). \\
\hline 1991 & $\begin{array}{l}\text { Special Rapporteur on the Right to Adequate Housing: Sr. Rajindar Sachar. India. } \\
\text { Relator Especial da ONU para o direito à moradia adequada. }\end{array}$ \\
\hline 1991 & $\begin{array}{l}\text { Primeiro "injunction" (mandato de segurança) contra um Estado Parte do Pidesc. República } \\
\text { Dominicana. Documento da ONU no E/C.12/1991/4. }\end{array}$ \\
\hline 1991 & $\begin{array}{l}\text { International Covenant on Economic, Social and Cultural Rigths (ICESCR). Pacto Internacional de } \\
\text { Direitos Econômicos, Sociais e Culturais (PIDESC). El derecho a una vivienda adecuada (Art.11, párr. } \\
\text { 1): 13/12/91. CESCR Observación general № } 4.6^{\circ} \text { período de sesiones (1991). }\end{array}$ \\
\hline 1992 & $\begin{array}{l}\text { United Nations Conference on Environment and Development. Rio de Janeiro, Brasil. } \\
\text { Conferência das Nações Unidas sobre Meio Ambiente e Desenvolvimento (Cnumad). }\end{array}$ \\
\hline 1992 & Working Paper on the Right to Adequate Housing. Documento da ONU no-E/CN.4/Sub.2/1992/15 \\
\hline 1994 & $\begin{array}{l}\text { Draft International Convention on Housing Rights. Prepared by the UN Special Rapporteur on Housing } \\
\text { Rights: Rajindar Sachar. Documento da ONU no E/CN.4/Sub.2/1994/2, agosto. }\end{array}$ \\
\hline 1995 & ONU publica Towards A Housing Rights Strategy. Documento no HS/C/15/INF.7 \\
\hline 1995 & $\begin{array}{l}\text { Final Report of the Special Rapporteur on the Right to Adequate Housing: Sr. Rajindar Sachar. } \\
\text { India. Documento da ONU no E/CN.4/Sub.2/1995/12. } 12 \text { julho } 1995 .\end{array}$ \\
\hline 1996 & $\begin{array}{l}\text { Second United Nations Conference on Human Settlements (Habitat II). } \\
\text { Segunda Conferência sobre Assentamentos Humanos (Habitat II). Istambul, Turquia. }\end{array}$ \\
\hline 1996 & ONU publica Forced Evictions and Human Rights, 'UN Fact Sheet no 25 '. \\
\hline 1997 & ONU publica The Human Right to Housing, 'UN Fact Sheet no 21'. \\
\hline 1997 & $\begin{array}{l}\text { Aprovada estratégia da ONU sobre o direito à moradia. Housing Rights: Strategy for the Progressive } \\
\text { Realization of the Right to Adequate Housing. }\end{array}$ \\
\hline 1997 & $\begin{array}{l}\text { Observação no } 7 \text { do Pidesc sobre despejos forçados. General Comment no } 7 \text { on the Right to Adequate } \\
\text { Housing: Forced Evictions. Documento da ONU no E/C.12/1997/4. }\end{array}$ \\
\hline 1998 & $\begin{array}{l}\text { Women and the right to land, property and adequate housing. Sub-Commission Session 50a. } \\
\text { Primeira resolução da ONU sobre a mulher e a moradia, a terra e a propriedade. Documento da ONU } \\
\text { no E/CN.4/SUB.2/RES/1998/15. }\end{array}$ \\
\hline 1998 & $\begin{array}{l}\text { First resolution on Housing and Property Restitution in the Context of Refugee and IDP Return. IDPS } \\
\text { - Internal Displaced Persons. } \\
\text { Primeira resolução sobre moradia e restituição da propriedade no contexto de refugiados e } \\
\text { deslocados internos. }\end{array}$ \\
\hline 1999 & Programa United Nations Housing Rights aprovado. \\
\hline 1999 & Global Campaign for Secure Tenure. Programa global pela segurança da posse. \\
\hline 2000 & $\begin{array}{l}\text { Special Rapporteur on adequate housing as a component of the right to an adequate standard of } \\
\text { living, and on the right to non-discrimination in this context: Sr. Miloon Kothari. India. 2000-2008. } \\
\text { Relator especial sobre a moradia adequada como elemento do direito a um nível de vida adequado, } \\
\text { e sobre o direito à não discriminação nesse contexto. }\end{array}$ \\
\hline
\end{tabular}




\begin{tabular}{|l|l|}
\hline Ano & $\begin{array}{l}\text { Eventos mais significativos da ONU que relatam o Direito à Moradia Adequada e } \\
\text { assuntos conexos }\end{array}$ \\
\hline 2000 & Millennium Development Goals (MDGs). Objetivos de Desenvolvimento do Milênio (ODM). \\
\hline 2002 & ONU publica Housing Rights Legislation. \\
\hline 2002 & World Summit on Sustainable Development (WSSD). Cumbre de la Tierra. Johannesburgo. \\
\hline 2005 & $\begin{array}{l}\text { The Pinheiro Principles. United Nations Principles on Housing and Property Restitution for Refugees } \\
\text { and Displaced Persons. } \\
\text { Princípios Pinheiro. Princípios de habitação e restituição de bens de refugiados e pessoas } \\
\text { deslocadas. }\end{array}$ \\
\hline 2008 & $\begin{array}{l}\text { Special Rapporteur on adequate housing as a component of the right to an adequate standard of } \\
\text { living, and on the right to non-discrimination in this context: Sra. Raquel Rolnik. Brasil. 2008-2014. }\end{array}$ \\
\hline 2009 & ONU publica The Right to Adequate Housing. UN Fact Sheet no 21. Rev.1'. \\
\hline 2012 & $\begin{array}{l}\text { World Urban Forum 5. } \\
\text { Foro Urbano Mundial 5. Rio de Janeiro, Brasil }\end{array}$ \\
\hline 2014 & $\begin{array}{l}\text { ONU publica Women and the Right to Adequate Housing. Documento no E.11.XIV.4. } \\
\text { Foro Urbano Mundial (FUM). Medellín. Colômbia }\end{array}$ \\
\hline 2014 & $\begin{array}{l}\text { Special Rapporteur on adequate housing as a component of the right to an adequate standard of } \\
\text { living, and on the right to non-discrimination in this context: Sra. Leilani Farha. Canadá. 2014-2021. }\end{array}$ \\
\hline 2016 & $\begin{array}{l}\text { Third United Nations Conference on Human Settlements (Habitat III). } \\
\text { Terceira Conferência das Nações Unidas sobre Assentamentos Humanos (Habitat III). Quito, } \\
\text { Equador. Outubro 2016. }\end{array}$ \\
\hline
\end{tabular}

Quadro 1.2 - Lista cronológica dos eventos e documentos mais significativos da ONU que relatam o direito à moradia e assuntos conexos.

Fonte: Elaboração própria.

A organização das Nações Unidas (ONU), como agente multilateral, é relevante a respeito de pensar a provisão de habitação e a gestão de assentamentos humanos. De acordo com o problema de habitação a se solucionar, desde seu início essa instituição tem estabelecido por período de tempo, nas suas resoluções e instrumentos de direito internacional, as noções afins à moradia adequada, as quais contêm recomendações de política, mandatórias para as nações integrantes; assim, a abordagem das Nações Unidas se torna a perspectiva dos países para políticas de habitação, de assentamentos humanos e de meio ambiente.

Nos primórdios da ONU, a moradia vislumbrava-se como "abrigo de emergência", por conta das guerras na Europa. Depois, a habitação vira como um "componente do nível de vida adequado" na Declaração Universal dos Direitos do Homem (DUDH) de 1948. Mas, como os países não tinham como oferecer moradia grátis, o problema volta-se nos finais da década de 1950, para o acesso à "moradia econômica e os serviços comunitários conexos", levando-se em consideração que essa pode ser atingida desde a capacidade econômica do trabalhador, que se refere a um salário real obtido por seu trabalho.

No início da década de 1970 é a noção de "moradia adequada" como componente do "direito a um nível de vida adequado", com fundamento no Pacto Internacional de 
Direitos Econômicos, Sociais e Culturais (PIDESC) de 1966. Depois, no Pidesc de 1991, estabelece-se o indicador "direito à moradia adequada", delimitado por sete elementos e considerado pelos especialistas como o instrumento mais pertinente; além de adotado nas resoluções e nos Relatórios Globais da ONU. No entanto, mantem-se que, desde finais da década de 1950, o acesso ao domicílio econômico e aos serviços conexos é segundo a capacidade econômica do habitante.

As condições qualitativas de vida e de habitação estavam sendo abordadas pela Organização Internacional do Trabalho (OIT), a partir das condições nos lugares de emprego e nas moradias dadas como parte do salário aos trabalhadores, o qual se reflete na Recomendação № 115 sobre Trabalhadores da OIT (1961). Esta foi uma orientação paralela à ONU nas décadas de 1960 e 1970, feita por seus corpos anexos e exposta nos documentos anexos e complementares, mais não é visível, uma vez que não está inserida nas resoluções que são as que ditam as diretrizes e abordagens a serem seguidas.

No entanto, um primeiro consenso entre a abordagem paralela em documentos anexos e a orientação oferecida pela ONU em seus documentos diretrizes, foi apresentada no documento guia de especialistas das Naciones Unidas (1961), cujas variáveis sobre a moradia e outros componentes do nível de vida começaram a ser aplicadas e reveladas em dados nos relatórios da situação social do mundo de 1967, para logo serem estabelecidos desde meados da década de 1970, como variáveis do Indicador de Necessidades Básicas Insatisfeitas (NBI) para América Latina e 0 Caribe, como variáveis dos indicadores de habitação desses países; depois, como o Indicador de Assentamentos Precários dos Objetivos de Desenvolvimento do Milênio (ODM) de 2000.

Quando, nos finais da década de 1960, a ONU verifica os danos e a diminuição nos recursos do "meio humano", resoluções e pesquisas chamam a atenção sobre esse conteúdo, até se desenvolver a Conferência sobre o Meio Humano de 1972, que logo muda o nome para "Meio Ambiente" no ano de 1992. Mas também são desenvolvidas as Conferências Mundiais de Assentamentos Humanos, Hábitat I - 1976 e Hábitat II 1996, que se focaram mais na gestão dos assentamentos e no controle dos recursos, ainda que contivessem um capítulo para moradia, em que adotam as variáveis instauradas no documento guia de especialistas das Naciones Unidas de 1961.

Desde a década de 1980 a ONU estabelece resoluções para o problema dos assentamentos humanos e do meio ambiente, diferenciadas por inteiro das que focam no tema da moradia. As resoluções sobre o problema de acesso econômico à habitação vão diminuindo, até que depois de 1992, por influxo do Pidesc de 1991, com seu indicador de moradia adequada, aludem ao direito à habitação, e na que o acesso a moradia deve estar inserido num marco de direitos. Os Objetivos de 
Desenvolvimento do Milênio do ano 2000 apresentam na forma de oito objetivos, novamente de forma integral, alvos para os assentamentos humanos, o meio ambiente e a moradia. $\mathrm{O}$ alvo 7D, que é o que tem a ver com a moradia, instituiu, como meta até 2020 , melhorar consideravelmente a vida de pelo menos 100 milhões de pessoas que vivem em bairros precários.

Assim, uma moradia adequada, conforme o Pidesc de 1991, significa ter mais do que um abrigo para se proteger do clima e dos vetores de enfermidades externas; significa também um lugar no qual se tenha privacidade e espaço suficiente para o indivíduo desenvolver a sua própria vida e a sua cultura; construído com materiais duráveis e seguros; com iluminação, aquecimento e ventilação suficientes; com infraestrutura básica adequada para serviços de água, esgoto e eliminação de resíduos; com acesso aos serviços urbanos; com segurança da posse; e, tudo isso, a um custo razoável.

Nada obstante, as recomendações de política de habitação contidas nas resoluções da ONU, nos decênios estabelecidos, nas conferências mundiais para a melhoria dos assentamentos humanos e para a conservação do meio ambiente; continuam as carências habitacionais e a degradação dos assentamentos humanos e do meio ambiente. Segundo dados sobre o progresso dos ODM no seu objetivo 7D, para 2014, a América Latina e O Caribe têm $23.5 \%$ da sua população vivendo em tugúrios; a África do Norte e a Subsaariana com $75 \%$; o Leste da Ásia com $28.2 \%, 35 \%$ para o sul, e $31 \%$ para o sudeste; Oceania com $24.1 \%$; $32.7 \%$ nas regiões em desenvolvimento. Essas percentagens correspondem à população urbana morando com pelo menos uma das seguintes quatro carências que correspondem às variáveis do indicador de assentamentos precários dos ODM para o 2020: falta de acesso a água potável, falta de acesso a saneamento, adensamento (três ou mais pessoas por quarto) e domicílios feitos de material não-durável ${ }^{25}$ (ONU, 2013).

Na Figura.1.1 apresentamos uma linha de tempo com os acontecimentos da ONU mais relevantes sobre a moradia adequada, em uma tentativa por condensar 0 pensamento dessa instituição quanto a provisão de habitação. A Figura 1.1 está composta por uma linha de tempo geral. Sobre a linha do tempo geral, mostramos as Convenções mais relevantes da ONU, e que respondem a cada um dos problemas de habitação a solucionar por período de tempo (indicados sob a linha de tempo geral).

Os textos localizados abaixo da linha do tempo geral, em negrito, tal como "abrigo de emergência", são problemas de habitação a serem solucionados, para os quais a ONU tem construído princípios de política e recomendações, que visam orientar a diversos

\footnotetext{
${ }^{25}$ Nestes dados a ONU não avaliou a segurança da posse como uma das variáveis do Indicador de Assentamentos Precários dos ODM.
} 
programas de ação nos países integrantes das Nações Unidas, buscando solucionar o problema mencionado. Estes programas de ação encontram-se na Figura 1.1 abaixo da linha de tempo de cada problema de habitação, e sob um período de tempo no qual se busca que esse programa de ação seja aplicado. Seguindo com o exemplo de "abrigo de emergência", os programas de ação desse período - entre 1946 e 1960 focaram-se em "diagnósticos sobre a moradia, o seu financiamento e a sua construção".

Uma descoberta é que depois da Hábitat I - 1976, uma linha de ação sobre os recursos da terra vai se configurando, até se separar nas resoluções do tema dos assentamentos humanos e do meio ambiente, formando três linhas de ação, separadas, e em algumas ocasiões contraditórias.

As três linhas de ação, as quais estão plotadas na Figura 1.1, são:

a) a da moradia, que busca o acesso à habitação e aos serviços básicos e urbanos, além de condições de habitabilidade;

b) a dos assentamentos humanos, que trata do controle e da regulação dos conglomerados humanos;

c) a do meio ambiente, que busca a regulação e o controle dos recursos do ambiente e a gestão dos resíduos humanos, químicos, além das armas nucleares.

No entanto, desde ONGs, outras agências alternativas e a ONU, veem se gestando o discurso sobre o direito à cidade, que, a nosso ver, vai ser uma linha de estudo intensa depois da Conferência Mundial sobre Assentamentos Humanos Habitat III, realizada no Equador no mês de outubro de 2016. A ONU tem como finalidade para a Hábitat III, uma nova agenda urbana.

Na Figura 1.1, tanto na linha do tempo geral, quanto nas linhas de ação: moradia, assentamentos humanos e meio ambiente, referenciamos os acontecimentos mais relevantes a respeito dessas linhas de ação. 


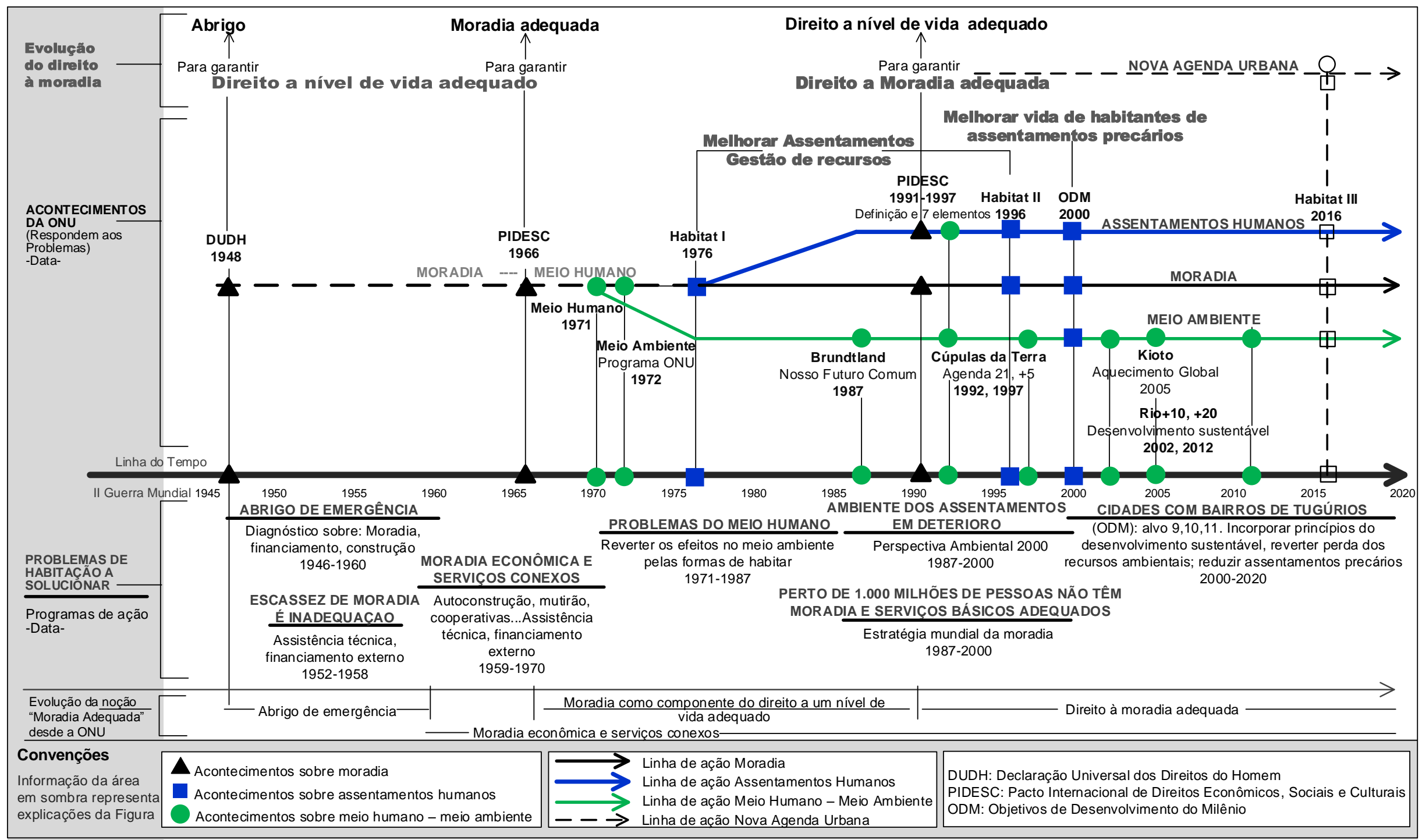

Figura 1.1 - Linha do tempo dos acontecimentos da ONU sobre moradia adequada

Fonte: Elaboração própria. 


\section{Capítulo 2}

\section{A MORADIA ADEQUADA NOS INDICADORES DE HABITAÇÃO DOS INSTITUTOS ESTATÍSTICOS DA AMÉRICA LATINA ${ }^{26}$}

\subsection{Introdução. Importância dos indicadores habitacionais}

Em consenso com vários autores, Pisarello expressa que é necessário pensar no componente subjetivo do direito à moradia, e em seu aspecto objetivo, para adotar indicadores que possam ser usados como parâmetro para distinguir a violação no que diz sobre as obrigações de um Estado no campo dos direitos habitacionais, pois os indicadores de habitação encerram o papel fundamental em delimitar o "mínimo" desse direito.

Existe uma ampla anuência que a coleta e a análise de dados estatísticos, e, de indicadores sociais e econômicos, constituem um elemento estrutural para o desenvolvimento de políticas públicas. No entanto, não se percebe com clareza a relevância dos indicadores para a efetivação dos direitos humanos, entre eles, os habitacionais. A importância dos indicadores está nesse papel fundamental sobre o conteúdo do direito, para que, ações ou omissões estatais ou de particulares, que minam o direito à moradia, não fiquem impunes e sejam consideradas como reais violações jurídicas das necessidades habitacionais (PISARELLO, 2003, p. 105, 108).

Assim, o propósito deste capítulo é identificar, a partir da revisão das variáveis de habitação que os países da América Latina aplicam, o que esses consideram ser o conteúdo da moradia adequada, refletido em documentos nacionais e de órgãos multilaterais que apresentam o "grau de Moradia Adequada" dessas nações, baseado nos indicadores nacionais e com alusão às adjetivações à moradia feitas nas Constituições dos países da América Latina.

\footnotetext{
${ }^{26}$ Capítulo publicado quase em sua totalidade na Revista INVI do novembro de 2015, como artigo da (MEJÍA-ESCALANTE, 2015), com título: "Necessidades básicas: bens e serviços duráveis da moradia adequada". O conteúdo deste Capítulo tem algumas variações com o artigo publicado na revista, para se adaptar às indicações da Universidade de São Paulo como tese de doutorado. A grande variação tem a ver com a síntese deste Capítulo.
} 
Este Capítulo apresenta nesta introdução a importância dos indicadores de habitação, para logo descrever a abordagem metodológica para a coleta e a análise dos indicadores de moradia dos países da América Latina. Depois uma revisão da gênese e evolução dos indicadores de Déficit Quantitativo, Qualitativo e do Indicador de Necesidades Básicas Insatisfechas (NBI), aplicados na América Latina, e vistos sob os critérios metodológicos dos Métodos Directo e o de Ingresos, os quais avaliam condições de vida. Para continuar com as definições das variáveis que constituem os indicadores de Déficit Quantitativo e Qualitativo. Logo fazemos uma comparação do conteúdo dessas variáveis com os sete elementos da moradia adequada do Pidesc de 1991. E, ao final, uma síntese sobre o que é para essas nações, a moradia adequada, desde os indicadores de habitação, como produção estatística.

\subsection{Indicadores de Habitação dos países da América Latina. Abordagem metodológica}

Resoluções sobre a moradia e documentos sobre variáveis de habitação da Organização das Nações Unidas (ONU) são revistos para este capítulo como fonte institucional da origem dos indicadores de Déficit Habitacional para os países da América Latina, o que desvenda uma política de assentamentos humanos baseada em um conjunto de necessidades básicas; para logo realizar uma breve revisão sobre o Indicador de Necesidades Básicas Insatisfechas (NBI) para a América Latina e O Caribe (ALC).

A seguir, um levantamento das variáveis de habitação que estes países aplicam e agrupam em Déficit Quantitativo e Qualitativo, para observar desde indicadores e variáveis de habitação, o que constitui a moradia adequada para as seguintes nações: Argentina, Bolívia, Brasil, Colômbia, Costa Rica, Cuba, Chile, Equador, El Salvador, Guatemala, Haiti, Honduras, México, Nicarágua, Panamá, Paraguai, Peru, Porto Rico, República Dominicana, Uruguai e Venezuela. A definição de cada variável é construída a partir da informação

Depois classificamos essas variáveis em categorias, estabelecidas pela autora, e construímos uma definição de cada uma delas, baseadas nas delimitações feitas nos documentos que contêm a metodologia para os censos de população e moradia, a qual está compilada nos Institutos de Estatística dos países em estudo. As categorias e as variáveis apresentam-se em duas línguas: português e espanhol. Seguidamente, uma comparação do conteúdo destas variáveis com os sete elementos do indicador "Moradia Adequada" do Pacto Internacional dos Direitos Econômicos, Sociais e Culturais (Pidesc) de 1991, cujo fim é revisar a concordância entre as variáveis de habitação e as do Pidesc. 
As variáveis habitacionais oficiais são obtidas de uma primeira fonte: as políticas habitacionais de cada país em estudo. A segunda fonte, com informação mais precisa, corresponde às fichas metodológicas e aos glossários associados aos Censos de População e Moradia, alojados nos Institutos Estatísticos destas nações. Para os países que não documentam, ou apenas muito vagamente, a metodologia de levantamento de dados para censos nacionais, pesquisamos na Encuesta de Hogares, feita nos países hispano-falantes ${ }^{27}$. A revisão de tão diversas fontes, com variados aprofundamentos, dificulta a consulta e a comparação sobre a situação habitacional das nações. Nos países que não se classificam as variáveis de moradia como quantitativas ou qualitativas, encontramos pesquisas privadas e acadêmicas que aplicam essa categorização, no entanto, os dados utilizados para esta pesquisa são os obtidos das fontes oficiais.

\subsection{De necessidades básicas ao Indicador de Necessidades Básicas Insatisfeitas (NBI). Gênese das variáveis do Déficit Habitacional nos países da América Latina}

As primeiras classificações oficiais de variáveis de moradia tanto quantitativas como qualitativas foram apresentadas nos working papers de apoio à The World Employment Conference de 1976, da International Labour Organization (ILO), cuja recomendação para essa conferência foi "a definição de um conjunto de necessidades básicas, o qual irá configurar um minimum standard of living [...], que uma sociedade deve definir para os grupos mais pobres da sua população" (ILO, 1976, p. 31, 7, tradução nossa). Para que o habitante tenha acesso ao conjunto de necessidades básicas, vale lembrar que o World Employment Programme define que cada pessoa possa dispor de um trabalho com remuneração adequada para o acesso às necessidades básicas ${ }^{28}$.

Para definir esse conjunto de necessidades básicas, era necessário construir uma boa metodologia de levantamento de dados sobre requisitos mínimos que uma família precisa para o consumo privado, e que pudessem ser comparados entre os diversos países:

\footnotetext{
${ }^{27}$ A Encuesta de Hogares corresponde no Brasil à Pesquisa Nacional por Amostra de Domicílios (PNAD).

${ }^{28}$ Lembramos que necessidades básicas são definidas como "o mínimo standard de vida que uma sociedade deveria estabelecer para a faixa mais pobre da população. A satisfação das necessidades básicas precisa de meios que satisfaçam os requisitos mínimos de uma família para consumo pessoal em componentes como: comida, abrigo, vestuário; o qual também inclui o acesso a serviços essenciais, tais como água potável, saneamento, transporte, saúde e educação. [...]. Implica que cada pessoa com capacidade de trabalhar, deve ter um trabalho adequadamente remunerado" (ILO, 1976, p. 7, tradução nossa). Citação textual no idioma da origem do documento, no capítulo 1, página 50.
} 
Basic needs, as understood in this Programme of Action [World Employment Programme], include two elements. First, they include certain minimum requirements of a family for private consumption: adequate food; shelter and clothing, as well as certain household equipment and furniture. Second, they include essential services provided by and for the community at large, such as safe drinking water, sanitation, public transport and health, educational and cultural facilities. A basic-needs-oriented policy implies the participation of the people in making the decisions which affect them through organizations of their own choice. [...]. It is important to recognize that the concept of basic needs is a country specific and dynamic concept. The concept of basic needs should be placed within a context of a nation's overall economic and social development. In no circumstances should it be taken to mean merely the minimum necessary for subsistence (ILO, 1977, p. 24).

O conjunto de necessidades básicas, política aplicada desde início da década de 1970, torna-se o programa de Necessidades Básicas para a América Latina e 0 Caribe (ALC) em meados dessa década, que deriva dos Relatórios da ILO na procura de melhores condições nos empregos, e que, depois na década de 1980, será avaliado como o Indicador de Necesidades Básicas Insatisfechas para América Latina y El Caribe (NBI).

Boltvinik afirma que uma primeira variante do NBI foi aplicada pela primeira vez no tempo da ditadura militar do Chile em 1975, e que, em meados de 1990, no México, no Chile e no Paraguai começa a se aplicar um indicador multidimensional que agrupa as medidas de Linha de Pobreza (LP) e do NBI, conhecido como Método de Medición Integrada de la Pobreza (MMIP), desenvolvido por esse autor. No entanto, ele afirma que nessa época a Comisión Económica para América Latina y El Caribe (Cepal) rejeita essa via multidimensional, considerando que a identificação dos pobres precisa ser estabelecida é a partir da variante da Canasta Normativa de Alimentos (CNA) do método da Linha de Pobreza (LP) (2013).

Fresneda estabelece que no início da década de 1980 o NBI é aplicado na Argentina pelo seu Instituto Nacional de Estadística y Censos (Indec), com a assistência da Comisión Económica para América Latina y El Caribe (Cepal - Óscar Altimir) e baseado no conjunto de necessidades básicas da ILO: alimento, vestuário, abrigo, serviços básicos). Depois, o NBI foi aplicado na metade desse decênio, simultaneamente na Colômbia e no Uruguai, com base na experiência da Argentina. A partir dos resultados desses três países, o NBI foi ministrado no final de 1980 e começo de 1990, com o suporte técnico do Proyecto Regional para la Superación de la Pobreza do (PNUD), da Cepal e de equipes técnicas nacionais: Bolívia, Costa Rica, 
Equador, Honduras, Nicarágua, Peru, República Dominicana e Venezuela; a Guatemala não utilizou equipes nacionais. Os Censos de População e Moradia e a Encuesta de Hogares foram as fontes dos dados (FRESNEDA, 2007, p. 12).

Segundo Feres e Mancero, como os censos permitem a desagregação geográfica, desde os inícios da aplicação do NBI construíram-se "mapas de pobreza", os quais hoje possibilitam visualizar graficamente e localizar as carências levantadas, no entanto, com a desvantagem da periodicidade dos dados, já que os censos são atualizados aproximadamente a cada dez anos. Em uma comparação dos indicadores $\mathrm{NBI}$ e LP, esses autores expressam que o primeiro só permite distinguir os hogares com carências críticas dos que não as têm, mas não a magnitude das carências; a LP utiliza a renda ou o consumo como indicador de bem-estar, ou o aprofundamento da pobreza - quão pobres são os pobres - e sua severidade -como está distribuída a pobreza -, mas não localiza geograficamente as carências da população. O NBI está relacionado com a pobreza estrutural, em contraposição com a LP, que se associa com a pobreza de conjuntura. A vantagem do NBI consiste em identificar com detalhe diversas carências que lesam à população (FERES e MANCERO, 2001, p. 8, 20, 29).

$\mathrm{Na}$ identificação dos pobres ou dos carentes dado um conjunto de "necessidades básicas", Sen expressa que podem ser empregados pelo menos dois métodos. $O$ Método Direto determina o conjunto de pessoas cuja cesta de consumo atual deixa insatisfeita alguma necessidade básica. O Método da Renda (Método de Ingreso ou Indirecto em espanhol) calcula a linha de pobreza (LP), para supor que por cima dessa LP todas as necessidades mínimas estão satisfeitas, ou seja, que, tenta detectar aqueles que não têm a capacidade de satisfazer as necessidades mínimas desde os seus recursos. Assim, a renda de uma pessoa pode ser observada não só como um instrumento para prever o consumo atual, mas como um indicador da sua capacidade de satisfazer as necessidades mínimas, independente que o indivíduo decida satisfazer ou não as necessidades. O primeiro método não envolve qualquer ideia de renda (1992, p. 317, 318).

Boltvinik relaciona esses métodos com a avaliação das necessidades básicas. Expõe que o Método Direto avalia os fatos, a (não) satisfação fática das necessidades segundo um requerimento normativo; o da Renda avalia a capacidade, identifica a satisfação potencial das necessidades humanas, e faz mais esclarecimento ao respeito. Quando comparando a variável observada, necessidade por necessidade, ou satisfactor por satisfactor, com seu limite regulamentar, é aplicado o método direto ou de necessidades básicas de medição da pobreza, que na América Latina é nomeado como método do NBI. Assim, uma diferença é que o NBI é multidimensional, avalia várias necessidades; o LP é unidimensional, avalia só a capacidade enquanto renda. Entretanto quase todos os métodos multidimensionais que se aplicam na década de 2010, misturam a verificação direta com a da renda $(2013$, p. $7,25,26)$. 
No Quadro 2.1, apresentam-se as variáveis do Indicador de Necesidades Básicas Insatisfechas (NBI) aplicado na América Latina.

\begin{tabular}{|l|l|}
\hline Necessidades Básicas & Variáveis extraídas dos Censos de População para aplicar o NBI \\
\hline \multirow{2}{*}{ Acesso à moradia } & Materiais de construção utilizados em chão, parede e teto \\
\cline { 2 - 3 } & $\begin{array}{l}\text { Número de pessoas no hogar } \\
\text { Número de quartos da moradia }\end{array}$ \\
\hline \multirow{2}{*}{ Acesso a serviços sanitários } & Fonte de abastecimento de água na moradia \\
\cline { 2 - 3 } & $\begin{array}{l}\text { Disponibilidade de serviço sanitário } \\
\text { Sistema de eliminação de dejetos }\end{array}$ \\
\hline Acesso à educação & $\begin{array}{l}\text { Idade dos integrantes do hogar } \\
\text { Assistência a um estabelecimento educativo }\end{array}$ \\
\hline \multirow{2}{*}{ Capacidade econômica } & $\begin{array}{l}\text { Idade dos integrantes do hogar } \\
\text { Último nível educativo aprovado do chefe de hogar } \\
\text { Número de pessoas no hogar } \\
\text { Condição da atividade econômica }\end{array}$ \\
\hline
\end{tabular}

Quadro 2.1 - Variáveis do Indicador de Necesidades Básicas Insatisfechas (NBI) aplicado nos países da América Latina

Fonte: (MEJÍA-ESCALANTE, 2015, p. 155).

Obs.: *Neste Quadro, usa-se a palavra hogar porque é a utilizada pela maioria dos países hispano-falantes da América Latina para designar o(s) grupo(s) ocupante(s) da moradia, que bem pode ser ou não consanguíneo, e que é a unidade de medida do NBI e do Déficit Habitacional da maior parte destas nações. A palavra hogar, em português, não alude ao grupo familiar como unidade de medida. O Brasil não aplica o NBI.

${ }^{* *}$ O nível educacional do chefe de hogar é tomado como uma aproximação aos recursos que ele pode gerar; considera, adicionalmente, o número de pessoas que dependem dele para determinar as necessidades a cobrir com a renda.

O NBI e o Déficit Habitacional somente avaliam fatos, porque, segundo Kaztman, indicadores deste tipo precisam cumprir cinco critérios: i) Agregação geográfica. Variáveis desde as que se procura localizar hogares no espaço e analisar as suas carências; o único instrumento de coleta de dados com a cobertura necessária para atingir este objetivo são os censos de população, que, por sua vez, põe limites à seleção das variáveis. ii) Representatividade. As variáveis selecionadas devem ser representativas de um conjunto de necessidades mais amplo das que investiga 0 censo. iii) Universalidade. Procura que o acesso a bens ou serviços, que permitem satisfazer necessidades básicas, esteja dentro das opções razoavelmente viáveis para todos os hogares do país, ou seja, que, as variáveis possam ser avaliadas em diversos âmbitos geográficos. iv) Estabilidade. É dada prioridade aos indicadores que refletem características relativamente permanentes dos hogares. v) Simplicidade. Aplica-se quando se têm duas ou mais variáveis de validez semelhante, para selecionar o indicador mais simples e facilmente compreensível (1995, p. 7).

Fresneda ratifica que o NBI, como método direto, é um indicador orientado unicamente a identificar carências na prestação de serviços e nos bens duráveis dos hogares, construído com dados da única fonte estatística que admite diferenças entre populações: os Censos de População e Moradia (FRESNEDA, 2007, p. 35). Kaztman 
afirma que o sucesso ou o fracasso de políticas destinadas a satisfazer cada carência é uma situação que pode ser observada quando aplicado o NBI. Contudo, o indicador $\mathrm{NBI}$ - e acrescentamos que o do Déficit Habitacional e o da Moradia Adecuada do Pidesc - não expõem a magnitude das carências. Essa última estimativa exigiria tarefas de revalidação que assegurem a representatividade dos indicadores selecionados em relação ao conjunto de satisfactores psicofísicos e culturais que constituem, em cada momento histórico, a mínima condição necessária para 0 funcionamento da vida humana em uma sociedade específica (1995, p. 8).

Sen, em "conceptos y medidas de pobreza", questiona sobre como definir as necessidades básicas envolvidas na identificação da pobreza: Em termos de bens e serviços ou de características desses bens? Esclarece a interroga com o seguinte exemplo: trigo, arroz, batatas, etc., são bens, enquanto as calorias, proteínas, vitaminas, etc., são características destes bens que o consumidor procura. Se cada característica pudesse ser obtida de um bem único, então seria fácil converter as necessidades de características em necessidades de bens; enquanto calorias são necessárias para a sobrevivência, não o são o trigo ou o arroz. As necessidades de características precedem aos bens, mas a multiplicidade de fontes não é, no entanto, uniforme. Muitos bens fornecem calorias ou proteínas; muitos poucos fornecem o abrigo (1992, p. 317). Retomando o exemplo dos alimentos, as características que identificam esse bem, podem se delimitar com maior facilidade que as da moradia, pois a habitação abrange características desde diversos âmbitos que, por sua vez, são bens e serviços.

Uma análise sob os critérios dos Métodos Direto e da Renda mostra que o conjunto de necessidades básicas está constituído por bens e serviços duráveis como a moradia e os serviços básicos, ou, em palavras de Sen (1992), como necessidades de bens. As variáveis habitacionais são características desses bens e serviços. Desde as variáveis é que se estabelece o mínimo a ser garantido, pelo qual são instituídas na forma de carências.

Essa análise também possibilita classificar as variáveis em categorias comuns aos países, estabelecidas pela autora, que mostra que os indicadores dos países da América Latina procuram diagnosticar carências habitacionais associadas só as características dos bens e serviços duráveis tais como a moradia e os serviços básicos. Sendo as categorias resultantes para o Déficit Quantitativo: i) estado da moradia, ii) densidade habitacional, iii) moradia a um valor acessível, iv) localização da moradia em área de risco. Para o Déficit Qualitativo: v) acesso a serviços básicos, vi) funcionalidade da moradia, vii) adensamento recuperável, viii) posse da moradia e do solo. Ver Quadros 2.2 e 2.3. 


\subsection{Déficit Habitacional Quantitativo e Qualitativo. Variáveis}

O Programa das Nações Unidas para os Assentamentos Humanos (ONUHábitat) apresenta em relatórios a cada dois anos, a situação mundial sobre a habitação. O de 2013 estabelece que além do estoque atual, preocupa a evolução do déficit, que aumentou de 38 milhões de moradias, calculadas para 1990, a uma cifra de entre 42 e 51 milhões, em 2011 (ONU-HÁBITAT, 2012, p. 63).

Os dados apresentados pela ONU são alarmantes, no entanto, por trás, estão os sistemas e os indicadores de habitação, cuja finalidade é fundamentar diagnósticos sobre a moradia, como insumo para criar programas de construção, reposição, ou melhoria de domicílios e de áreas residenciais. Essas variáveis são classificadas pelos países da América Latina em Déficit Quantitativo e Déficit Qualitativo.

Os Quadros 2.2 e 2.3 exibem as variáveis que constituem os Déficits de habitação para 21 países da América Latina. Expomos a denominação de Déficit Quantitativo (Quadro 2.2) e de Déficit Qualitativo (Quadro 2.3) na língua de origem de cada país; as variáveis habitacionais, que são, por sua vez, "características de bens e serviços" tais como a moradia e os serviços básicos; a classificação dessas variáveis por categorias comuns, estabelecidas pela autora e designadas como "categorias dos bens e serviços". As fontes de informação para construir esses Quadros 2.2 e 2.3, de elaboração própria, foram os institutos estatísticos dos 21 países da América Latina ${ }^{29}$.

\footnotetext{
${ }^{29}$ As fontes de informação para construir os Quadros 2.2 e 2.3 e a Figura 3.1 foram os institutos estatísticos das 21 nações da América Latina, na ordem por país: (SUBSECRETARIA DE DESARROLLO URBANO Y VIVIENDA. ARGENTINA); (INE - BOLIVIA); (FUNDAÇÃO JÕAO PINHEIRO, 2013; 2013a); (MINISTÉRIO DAS CIDADES, 2005); (DANE - COLOMBIA, 2009), (INEC COSTA RICA); (ONE - CUBA); (INE - CHILE); (MINVU - CHILE); (INEC - ECUADOR); (DIGESTYC EL SALVADOR, 2008); (INE - GUATEMALA); sem dados oficiais para o Haiti; (INE - HONDURAS); (INEGI - MÉXICO, 2010; 2010a); (INIDE - NICARAGUA); (INEC - PANAMÁ); (DGEEC - PARAGUAY); (INEI - PERÚ); (MINISTERIO DE VIVIENDA, CONSTRUCCIÓN Y SANEAMIENTO DE PERÚ); (INSTITUTO DE ESTADÍSTICAS DE PUERTO RICO); (ONE - REPÚBLICA DOMINICANA); (INE URUGUAY); (INE - VENEZUELA).
} 


\begin{tabular}{|c|c|c|c|c|c|c|c|c|c|c|c|c|c|c|c|c|c|c|c|c|c|c|c|c|}
\hline \multicolumn{25}{|c|}{ Variáveis do Déficit Quantitativo Habitacional nos países da América Latina } \\
\hline \multirow[b]{2}{*}{$\begin{array}{l}\text { Categorias } \\
\text { dos Bens e } \\
\text { Serviços }\end{array}$} & \multicolumn{2}{|r|}{ País } & 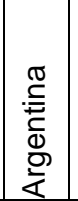 & \multirow{2}{*}{ 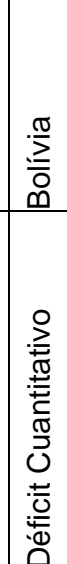 } & \multicolumn{2}{|c|}{$\begin{array}{l}\overline{\bar{g}} \\
\overline{\frac{\pi}{0}}\end{array}$} & $\begin{array}{l}\frac{\pi}{0} \\
\frac{0}{2} \\
\\
\\
\end{array}$ & $\begin{array}{l}\frac{\pi}{0} \\
\frac{0}{\pi} \\
\frac{\pi}{0} \\
0 \\
0 \\
0\end{array}$ & $\begin{array}{l}\frac{\pi}{0} \\
0 \\
0\end{array}$ & $\frac{\varrho}{\bar{T}}$ & 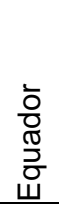 & 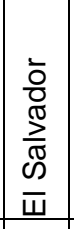 & 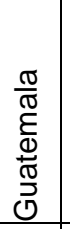 & $\begin{array}{l}: \bar{E} \\
\text { 莡 }\end{array}$ & 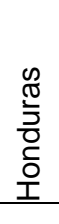 & 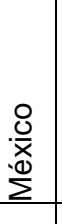 & \begin{tabular}{|c|c|} 
& $\frac{\pi}{3}$ \\
$\frac{\pi}{\pi}$ & \\
$\frac{\pi}{\pi}$ & \\
$\frac{\pi}{z}$ &
\end{tabular} & 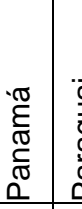 & \multicolumn{2}{|c|}{ 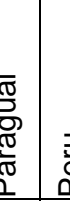 } & 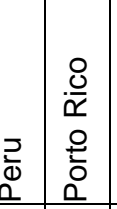 & \multicolumn{2}{|c|}{ 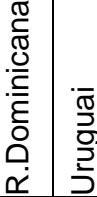 } & $\begin{array}{l}\frac{\pi}{0} \\
\frac{N}{N} \\
\frac{\mathbb{N}}{0} \\
>\end{array}$ \\
\hline & $\begin{array}{l}\text { Variáv } \\
\text { serviç }\end{array}$ & $\begin{array}{r}\text { Denominação de Déficit Quantitativo } \\
\text { (Língua de origem) }\end{array}$ & 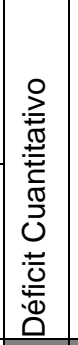 & & 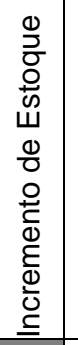 & 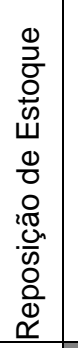 & 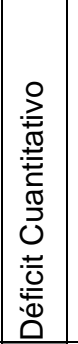 & 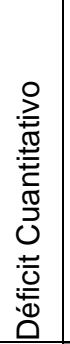 & 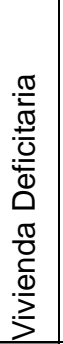 & 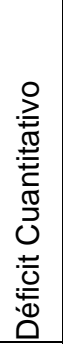 & 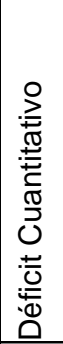 & 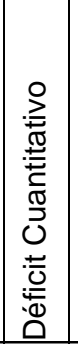 & 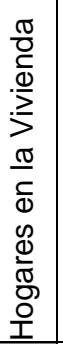 & 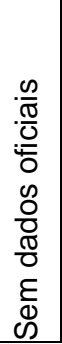 & 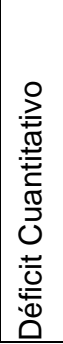 & 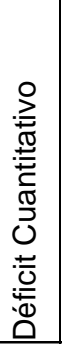 & 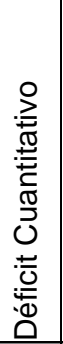 & 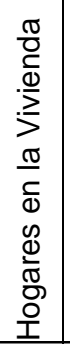 & 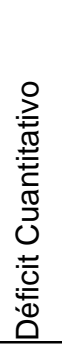 & 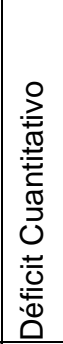 & 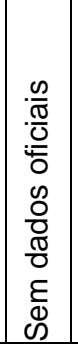 & 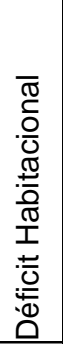 & 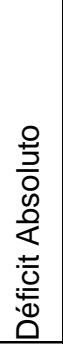 & 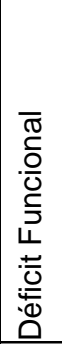 \\
\hline \multirow{2}{*}{$\begin{array}{l}\text { i) Estado da } \\
\text { moradia }\end{array}$} & \multicolumn{2}{|c|}{ Moradia precária } & & & & & & & & & & & & & & & & & & & & & & \\
\hline & \multicolumn{2}{|c|}{ Depreciação do imóvel } & & & & & & & & & & & & & & & & & & & & & & \\
\hline \multirow{8}{*}{$\begin{array}{l}\text { ii) Densidade } \\
\text { habitacional }\end{array}$} & \multicolumn{2}{|c|}{ Moradia vaga } & & & & & & & & & & & & & & & & & & & & & & \\
\hline & Hogar & sem moradia & & & & & & & & & & & & & & & & & & & & & & \\
\hline & Númel & ro pessoas por quarto & & & & & & & & & & & & & & & & & & & & & & \\
\hline & Adens & amento excessivo & & & & & & & & & & & & & & & & & & & & & & \\
\hline & & Independente no econômico & & & & & & & & & & & & & & & & & & & & & & \\
\hline & 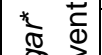 & Com orçamento comum & & & & & & & & & & & & & & & & & & & & & & \\
\hline & 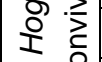 & Coabitação sem especificar & & & & & & & & & & & & & & & & & & & & & & \\
\hline & $+\bar{c}$ & Intenção constituir domicílio exclusivo & & & & & & & & & & & & & & & & & & & & & & \\
\hline iii) Moradia a um & Ônus & excessivo com aluguel & & & & & & & & & & & & & & & & & & & & & & \\
\hline valor acessível & Cômor & do cedido ou alugado & & & & & & & & & & & & & & & & & & & & & & \\
\hline iv) Localização & Morad & ia em ruína por desastre natural & & & & & & & & & & & & & & & & & & & & & & \\
\hline em área de risco & Morad & ia em risco, solo não recuperável & & & & & & & & & & & & & & & & & & & & & & \\
\hline
\end{tabular}

Quadro 2.2 - Variáveis do Déficit Quantitativo Habitacional nos países da América Latina.

Fonte: (MEJÍA-ESCALANTE, 2015, p. 159). Ver Nota de Rodapé N"29.

Obs.: A denominação do Déficit Quantitativo se apresenta na língua de cada país.

*A respeito da palavra hogar, ver observações do Quadro 2.1. 


\begin{tabular}{|c|c|c|c|c|c|c|c|c|c|c|c|c|c|c|c|c|c|c|c|c|c|}
\hline \multicolumn{22}{|c|}{ Variáveis do Déficit Qualitativo Habitacional nos países da América Latina } \\
\hline \multicolumn{2}{|r|}{ País } & 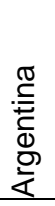 & 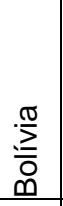 & \begin{tabular}{|l|}
$\overline{\bar{n}}$ \\
$\widetilde{n}$ \\
$\bar{m}$ \\
\end{tabular} & 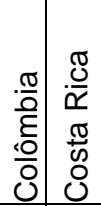 & $\begin{array}{l}\frac{\pi}{0} \\
03 \\
0\end{array}$ & $\frac{\varrho}{\frac{\varrho}{\bar{U}}}$ & \begin{tabular}{|c|}
$\bar{o}$ \\
$\overline{0}$ \\
$\frac{\sigma}{\partial}$ \\
$\bar{\sigma}$
\end{tabular} \mid & $\begin{array}{l}\overline{\bar{o}} \\
\frac{0}{\pi} \\
\frac{\pi}{\pi} \\
\infty \\
\bar{w} \\
\end{array}$ & 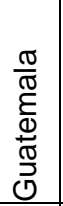 & $\begin{array}{l}:= \\
\frac{\bar{T}}{\bar{T}} \\
\end{array}$ & 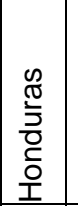 & 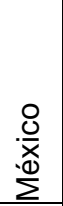 & 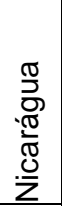 & 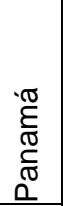 & 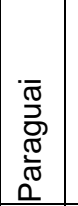 & $\begin{array}{l}\overrightarrow{2} \\
\frac{0}{0}\end{array}$ & $\begin{array}{l}\frac{0}{\pi} \\
\frac{0}{\pi} \\
o \\
0 \\
0\end{array}$ & 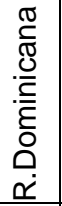 & $\begin{array}{l}\text { 㺃 } \\
\frac{3}{5} \\
\frac{2}{5}\end{array}$ & 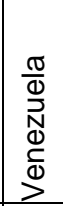 \\
\hline $\begin{array}{l}\text { Categorias } \\
\text { dos Bens e Serviços }\end{array}$ & $\begin{array}{r}\text { Denominação de Déficit Qualitativo } \\
\text { (Língua de origem) }\end{array}$ & 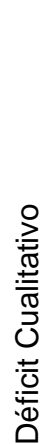 & 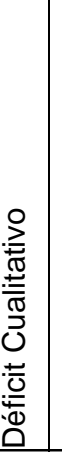 & 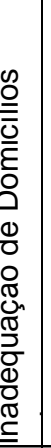 & 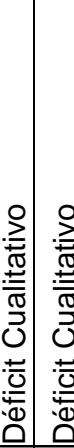 & 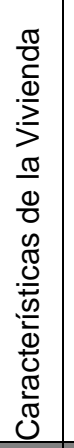 & 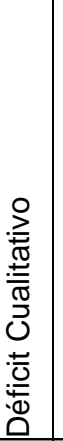 & 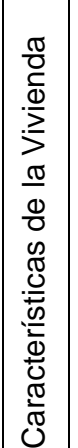 & 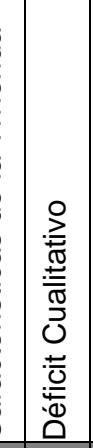 & 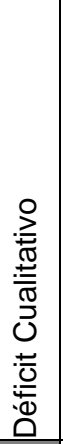 & 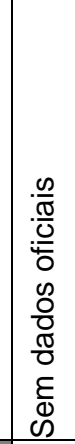 & 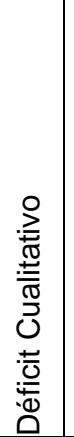 & 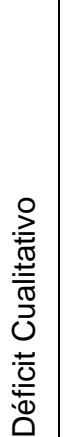 & 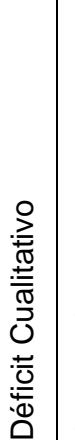 & 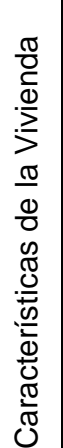 & 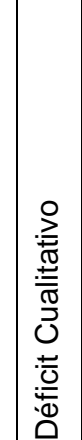 & 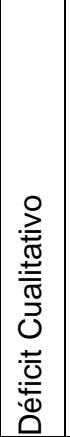 & 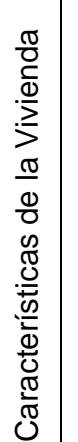 & 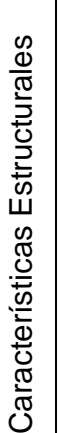 & 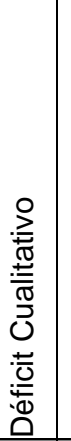 & 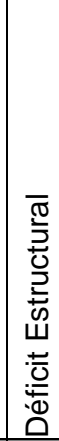 \\
\hline v) Acesso a serviços & Acesso a serviços básicos & & & & & & & & & & & & & & & & & & & & \\
\hline básicos & Acesso à energia elétrica, gás, água, gasolina & & & & & & & & & & & & & & & & & & & & \\
\hline \multirow{5}{*}{$\begin{array}{l}\text { vi) Funcionalidade da } \\
\text { moradia }\end{array}$} & Qualidade materiais: chão, teto, parede & & & & & & & & & & & & & & & & & & & & \\
\hline & Quarto para cozinhar & & & & & & & & & & & & & & & & & & & & \\
\hline & Instalação sanitária exclusiva & & & & & & & & & & & & & & & & & & & & \\
\hline & Móveis domésticos & & & & & & & & & & & & & & & & & & & & \\
\hline & Combustível para cozinhar & & & & & & & & & & & & & & & & & & & & \\
\hline \multirow{2}{*}{$\begin{array}{l}\text { vii) Adensamento } \\
\text { recuperável }\end{array}$} & Excessivo em domicílio próprio & & & & & & & & & & & & & & & & & & & & \\
\hline & Por quarto & & & & & & & & & & & & & & & & & & & & \\
\hline \multirow{2}{*}{$\begin{array}{l}\text { viii) Posse da } \\
\text { moradia e do solo }\end{array}$} & Inadequação fundiária urbana & & & & & & & & & & & & & & & & & & & & \\
\hline & Tipo de posse & & & & & & & & & & & & & & & & & & & & \\
\hline
\end{tabular}

Quadro 2.3 - Variáveis do Déficit Qualitativo Habitacional nos países da América Latina.

Fonte: (MEJÍA-ESCALANTE, 2015, p. 161). Ver Nota de Rodapé N"29.

Obs.: A denominação do Déficit Qualitativo se apresenta na língua de cada país.

O "tipo de posse" não é uma variável do Déficit Habitacional destes países, com exceção do Brasil, mas os Censos de População e Moradia levantam dados ao respeito. Foi considerada essa variável neste Quadro, porquanto é uma variável do elemento "Segurança da Posse" do indicador Moradia Adequada do Pidesc de 1991. 
A seguir, uma definição de cada variável - em textos sublinhados - elaborada a partir da revisão das fontes dos Quadros 2.2 e 2.3 (Institutos Estatísticos dos países em estudo). Um elemento a se considerar nessas definições são as noções de "família" e "hogar". Utiliza-se neste texto, a palavra hogar - ainda que não exista em português com significado aproximado de família -, para definir o grupo ocupante da moradia, que bem pode ser ou não consanguíneo; pois na maior parte dos países da América Latina hispano-falante, o hogar utiliza-se como unidade básica de medição, que é diferente de família. As exceções são Cuba, Paraguai e Peru, os quais aplicam a família constituída por um grupo familiar consanguíneo como unidade de análise. Cuba refere-se a hogar unipersonal quando é um único integrante. Para o Haiti, Porto Rico e Venezuela não encontramos informação oficial a esse respeito.

Os países que aplicam o hogar como unidade oficial de medição, empregam a seguinte definição da ONU: a pessoa ou grupo de pessoas que moram no mesmo domicílio, e que, no âmbito econômico, conseguem, para todos, a comida e outros elementos essenciais, e cozinham para todos os integrantes, independentemente se mora $(m)$ ou não com outra pessoa ou grupo; esse grupo pode ter ou não consanguinidade (UNITED NATIONS, 1977, p. 26). A expressão do anterior mais conhecida em espanhol é "comen de la misma olla y duermen bajo un mismo techo". Uma "família convivente", em português; um hogar allegado ou em cohabitación, em espanhol; ou a multi-person household, em inglês são as acepções nessas línguas, para se referir aos hogares que moram juntos. As unidades de medida "família" e "hogar" e suas distinções dificulta a comparação entre os países.

O hogar convivente na Costa Rica, Chile, Equador, Guatemala, México, Paraguai e na República Dominicana diagnosticam os "hogares que moram com outros no mesmo domicílio, mas que são independentes economicamente". No Brasil, a família convivente secundária é aquela constituída por "no mínimo, duas pessoas, ligadas por laço de parentesco, dependência doméstica ou normas de convivência, e que residem no mesmo domicílio com outra família, denominada principal" (FUNDAÇÃO JOÃO PINHEIRO, 2013a, p. 13), sem especificar, contudo, assuntos de dependência econômica; além disso, identifica a "família com intenção de constituir domicílio exclusivo".

No Brasil, o idioma é o português, e nos outros vinte países é o espanhol. Cada categoria e suas variáveis são oferecidas nessas duas línguas; isso porque, em estudos comparados sobre habitação entre os países da América Latina, primeiramente, não há um documento que agrupe as variáveis empregadas, e, segundo, pela dificuldade de entendimento entre as duas línguas para noções similares, que, ademais, abrangem assuntos culturais; inclusive, entre os países nos quais se fala espanhol, termos similares podem ter significados próprios segundo suas dinâmicas. 
Dados oficiais sobre Porto Rico e o Haiti não foram encontrados. Sobre o Haiti, perto de 100.000 habitantes ainda mora em campos improvisados após o terremoto de 2010, que deixou para essa data a mais de 1.5 milhões de pessoas sem teto, é um caso particular, assim, as variáveis habitacionais oficiais não podem ser aplicadas para o que hoje acontece nessa nação.

\subsubsection{Variáveis de Déficit Quantitativo e suas definições. [Quadro 2.2]}

\section{Déficit Quantitativo Habitacional}

A definição mais tradicional é dada pelo número de unidades faltantes de domicílios, para que cada hogar tenha acesso a uma moradia para seu próprio uso. No entanto, engloba além do anterior, a necessidade de construção de novas moradias para repor as que não são recuperáveis, aquelas sem condições de serem habitadas; pessoas sem domicílio; hogares em adensamento não recuperável; reposição de imóveis com fins não residenciais, mas com uso residencial.

\section{i) Estado da moradia / Estado de la vivienda}

Moradia sem condições físicas de ser habitada, devido à precariedade dos materiais ou da estrutura, além da sua vida útil.

\section{Moradia precária / Vivienda precaria}

Moradia sem condições físicas de ser habitada é aquela que não pode ser melhorada devido à precariedade dos materiais ou em virtude de ter sofrido desgaste da estrutura, em decorrência das condições de insalubridade. No Brasil, na Guatemala, no Panamá, entre outros, insere-se nessa variável os domicílios improvisados, como os imóveis não residenciais utilizados com fins de moradia, embaixo das pontes, na rua, nas cavernas; além dos domicílios rústicos, como barracas e tugurios. Na Costa Rica, o "precário" também alude a "toma de tierras" (em espanhol para esse país), ou seja, a moradia ou o solo ocupado por quem não é o proprietário.

\section{Depreciação do imóvel / Antigüedad de la vivienda}

Limite para a vida útil de um imóvel. No Brasil, é chamada de "depreciação do imóvel"; os demais países utilizam Antigüedad de la vivienda. Só algumas das nações que aplicam essa variável, definem o tempo - mais de 50 anos - para exigir reparos ao domicílio.

\section{ii) Densidade habitacional / Densidad habitacional}

Quantidade de grupos (hogares) que moram em um domicílio. Variável classificada pelos países como quantitativa, porque a utilizam para determinar a quantidade de domicílios faltantes para os hogares que compartem moradia, não para assuntos de 
habitabilidade ou de bem-estar dentro do domicílio. Algumas das nações de fala hispana a denominam "condición de ocupación de la vivienda".

\section{Moradia vaga / Vivienda desocupada}

Domicílio abandonado, sem uso, em reparação, ocasional, destruído ou utilizado para outras atividades que não são as residenciais.

\section{Hogar sem moradia / Hogar sin vivienda}

Pessoa ou grupo de pessoas que mora nas ruas e nos alojamentos provisórios.

\section{Número de pessoas por quarto / Número de personas por cuarto}

Englobam-se nessa variável: quantidade de quartos utilizados para dormir, quantidade de dormitórios, número de pessoas por quarto, número de pessoas por dormitório. Mais da metade dos países aplicam alguma dessas variantes, mas só algumas das nações, cruzam os dados para obter o adensamento excessivo; ou bem, diagnosticam o adensamento sem apresentar os dados dessas variantes. Por isso, neste texto, expõe-se por separado a variável "número de pessoas por quarto", do "adensamento excessivo".

\section{Adensamento excessivo / Hacinamiento no recuperable}

Estipula-se como o resultado da divisão do número de pessoas que moram em um domicílio, pelo número de quartos nos quais elas dormem. Entenda-se por quarto para dormir, tanto os dormitórios, quanto qualquer lugar da moradia com esse uso, pois alguns países incluem a cozinha, o banheiro e a garagem, entre outros. O Déficit Quantitativo revisa o adensamento excessivo ou o hacinamiento no recuperable, ou seja, quando não há possibilidade de diminuir o grau de coabitação. A Bolívia faz diferença entre o cálculo de adensamento para hogar unipessoal, do conformado por mais integrantes. A Colômbia o determina a partir de cinco pessoas. A Costa Rica oferece dados sobre o seu grau de hacinamiento, mas não especifica como foi obtido. O Uruguai o considera quando há mais de três pessoas dormindo num quarto para esse uso, ou, mais de duas, num quarto para outro uso. O Paraguai define essa variável como "promedio de personas por vivienda". O Brasil estabelece uma distinção: o "adensamento excessivo de domicílios alugados" que se inclui nesta variável, e, o "adensamento excessivo de domicílios próprios" que se insere no Déficit Qualitativo; a diferença para o Brasil radica na posse do domicílio: para o quantitativo revisa-se a moradia alugada e para o qualitativo, é a própria. Por outro lado, a palavra "adensamiento" (em espanhol) tem a ver com o adensamento no urbano ou em 
conglomerados, assim, essa palavra não se utiliza nessa língua para se referir ao adensamento em quartos ${ }^{30}$.

Hogar convivente independente no econômico / Hogar allegado independiente en lo económico.

Hogar secundário de qualquer tamanho e configuração, considerado secundário porque habita na mesma moradia com outros hogares, mas que é independente economicamente do hogar primário, portanto, poderia ter a capacidade de manter uma moradia independente. No Chile a variável é "número de hogares dentro de la vivienda". No Paraguai é "agrupamiento externo".

Hogar convivente com orçamento comum / Hogar allegado con presupuesto común Hogar secundário, de qualquer tamanho e configuração, que habita na mesma moradia com outros hogares, com orçamento comum, e que prepara conjuntamente os alimentos. Para o Chile e a Costa Rica a denominação é "hogar particular"; para o Paraguai é "agrupamiento interno"; Cuba a diagnostica como "hogar censal"; no Peru é "carencia en exclusividad de uso de la vivienda".

Hogar convivente sem especificar ou em coabitação / Hogar allegado sin especificar o en cohabitación

Hogar secundário de qualquer tamanho e configuração, que habita na mesma moradia com outros hogares, mas não se faz distinção entre hogares independentes no econômico e com orçamento comum. O Chile a identifica como "hogar colectivo".

Hogar convivente com intenção de constituir domicílio exclusivo / Hogar allegado con intención de constituir domicilio exclusivo

Hogar secundário de qualquer tamanho e configuração, que habita na mesma moradia com outros hogares que pretende e tem a capacidade de constituir domicílio exclusivo. O Brasil, como único país que a diagnostica, inclui essa variável a partir de 2007.

\section{iii) Moradia a um valor acessível / Vivienda accesible en el valor}

Capacidade econômica do hogar para o acesso a uma moradia adequada com todos seus serviços básicos e urbanos, além de assumir as despesas de manutenção e impostos, seja como proprietário, ocupante, inquilino ou outra forma de posse.

$30 \mathrm{O}$ indicador que iria refletir de maneira mais adequada o adensamento excessivo é o que se calcula a partir dos metros quadrados por cômodo, em comparação com o número de pessoas que dormem nele; no entanto, nos Censos de População e Moradia analisados não se dispõe da área dos quartos. A nível internacional o padrão é de $4 \mathrm{~m}^{2}$ por pessoa. 
Ônus excessivo com aluguel urbano / Porcentaje de ingresos familiares destinado a pago de alquiler urbano

O ônus excessivo com aluguel para os países de fala hispânica é considerado quando mais de $30 \%$ da renda familiar é utilizada para o pagamento do aluguel, independentemente do nível econômico do grupo familiar. Para o Brasil é delimitado como famílias urbanas com renda de até três salários mínimos, no que se inclui a renda da família secundária convivente, e, que despende $30 \%$ ou mais de sua renda com alugue ${ }^{31}$. Quer dizer que, -depois de 2007-, o Brasil aplica a renda domiciliar e não a familiar. Os restantes países não aplicam essa distinção.

\section{Cômodo cedido ou alugado / Cuarto cedido o alquilado}

Compartimentos integrantes do domicílio separados por paredes, incluídos banheiros e cozinha, desde que constituam parte integrante da moradia, e que sejam alugados ou cedidos. A Bolívia, o Brasil, Cuba, a Guatemala e o Uruguai são os países que diagnosticam essa situação, não como uma questão de insuficiência econômica ou um assunto de habitabilidade, conforto ou privacidade, mas na busca de conhecer se existe coabitação, razão pela qual essa variável faz parte do Déficit Quantitativo.

\section{iv) Localização da moradia em área de risco não recuperável / Localización de la vivienda en área de riesgo no recuperable}

Localização da moradia em área propensa a desastre natural e quando o risco não pode ser diminuído. Os países que diagnosticam as variáveis dessa categoria como Déficit Habitacional ou para os seus censos de população e Encuestas de Hogares, realizam mapas de áreas de risco que determinam o grau de vulnerabilidade das áreas residenciais. Se o solo ou a moradia não podem ser melhorados para diminuir o risco da perda do imóvel por desastre, supõe-se que os domicílios dessa área serão considerados para remoção, mas em alguns países é ambíguo o tratamento a ser dado às pessoas deslocadas por essa situação, como consequência, essa categoria não se relaciona com programas de reassentamento; suas variáveis são classificadas pelos países como quantitativas, já que determinam o número de moradias a serem derrubadas, mas não se associam com assuntos de bem-estar dentro do domicílio ou no processo de remoção, de habitabilidade, de saúde, de segurança física ou de posse.

\footnotetext{
31 O ônus excessivo é considerado no Brasil Déficit Quantitativo e não Qualitativo ou de inadequação habitacional, já que, "[...] para determinada parcela pobre da sociedade, o aluguel não é uma opção, diferentemente do que ocorre com alguns setores da classe média. Para eles [classe média], pagar aluguel em bairros melhores e de mais status é preferível a comprar imóvel em áreas suburbanas de pior localização" (FUNDAÇÃO JOÃO PINHEIRO, 2013a, p. 18).
} 
Moradia em ruína por desastre natural / Vivienda en ruina por desastre natural Moradia destruída parcial ou totalmente por desastre natural.

Moradia em risco, solo não recuperável / Vivienda en riesgo, terreno no recuperable Moradia localizada em área de risco, na qual o imóvel ou o solo não podem ser melhorados para diminuir o risco de desastre. A maior parte das nações determina nos seus censos somente o risco natural, sem considerar outros tipos de risco associados a formas de habitar ou costumes, a poluição, contaminação do entorno ou dos recursos, que poriam em risco morar no imóvel.

\subsubsection{Variáveis de Déficit Qualitativo e suas definições. [Quadro 2.3]}

\section{Déficit Qualitativo Habitacional}

O Déficit Qualitativo busca diagnosticar o conforto dos moradores. Em resposta às inadequações, aplicam-se programas de melhoria de domicílios. Ele revisa o acesso a serviços básicos, o tipo de material utilizado, os espaços funcionais da moradia, o adensamento (hacinamiento) que pode ser diminuído, e a posse da moradia e do solo. Em função das particularidades dos domicílios das áreas rurais, o Déficit Qualitativo é calculado apenas para as áreas urbanas, poucos países estabelecem variáveis para as áreas rurais.

\section{v) Acesso a serviços básicos / Acceso a servicios básicos}

Domicílios com acesso a serviços básicos como: energia, água potável, esgoto ou fossa séptica, coleta de lixo, gás.

\section{Acesso a serviços básicos / Acceso a servicios básicos}

Domicílios com acesso a serviços básicos: energia, água potável, esgoto ou fossa séptica.

Acesso à energia elétrica, gás, água, gasolina / Acceso a energía eléctrica, gas, agua, gasolina

O acesso a esses serviços é uma variável de Porto Rico. Sem dados oficiais mais específicos.

\section{vi) Funcionalidade da moradia / Funcionalidad de la vivienda}

Revisa o tipo de material utilizado na construção do domicílio e a sua durabilidade; e os espaços funcionais ou separados e diferenciados por atividades: cozinhar, asseio, dormir, entre outras, que o que busca é diminuir o risco de contaminação e manter a privacidade. 
Tipo e qualidade dos materiais de chão, teto e parede / Tipo y calidad de los materiales en piso, techo y pared

Refere-se ao tipo de material utilizado para construir a moradia, sua durabilidade e qualidade, além de distinguir a prevalência dos materiais do chão, teto e parede industrializados, tradicionais, naturais ou descartáveis.

Moradia urbana com quarto para cozinhar / Vivienda urbana con cuarto para cocinar A revisão das fichas metodológicas dos institutos estatísticos permite estabelecer que a moradia tradicional, ou seja, o domicilio com quartos separados para cozinhar, dormir e para o asseio, para um grupo familiar de país e filhos é a que se diagnostica com essa variável. Examina os hogares que preparam os alimentos em um quarto que também é utilizado para dormir ou para outras atividades, o que iria proporcionar desconforto e risco de contaminação. Cozinhar no quarto é recorrente nos domicílios que alugam quartos ou camas para grupos que migram para as cidades como: deslocados por violência ou por desastre natural, estudantes, indígenas, migrantes; domicílios nos quais ademais se oferecem serviço compartilhado de cozinha, banheiro, asseio. Situação também observada nos abrigos para idosos ou para moradores de rua. Este tipo de domicílios apresenta várias denominações: cortiço, casa de cômodo, cabeça-de-porco; ou em espanhol: inquilinato, callejón, conventillo, corralón, cuartería, pensión, vecindad, entre outras nomeações. O domicílio com serviços compartilhados está sendo visibilizado nos censos da maioria dos países como mais um tipo de moradia, e não como parte do indicador do Déficit Habitacional. A Bolívia e a República Dominicana fazem foco nas moradias de espaços únicos, em que se cozinha, dorme, estuda, trabalha, buscando solucionar risco de contaminação e fogo, mas não de condições de vida, privacidade ou intimidade. A Argentina, Cuba, Chile, Guatemala, Honduras, Nicarágua, Peru e a Venezuela levantam a quantidade de moradias com serviços compartilhados, com independência dessa variável.

Instalação sanitária domiciliária exclusiva / Unidad sanitaria domiciliar exclusiva Domicílio com banheiro: chuveiro e vaso sanitário ou fossa séptica. A maior parte dos países aplica regulações nacionais diferenciadas para área urbana e rural, a respeito desta variável.

\section{Móveis domésticos / Muebles domésticos}

Disponibilidade no hogar de equipamentos para cozinhar, pessoais e mais outros para as atividades domésticas e de lazer.

\section{Combustível para cozinhar / Combustible para cocinar}

Combustível utilizado para cozinhar. Revisa o risco de contaminação e o perigo de fogo. 


\section{vii) Adensamento recuperável / Hacinamiento mitigable}

Estipula-se como o resultado da divisão do número de pessoas que moram em um domicílio, pelo número de quartos nos quais elas dormem. O Déficit Qualitativo revisa o adensamento ou o hacinamiento recuperável, ou seja, quando há possibilidade de diminuir o grau de coabitação. Alguns países contemplam essa variável para o rural no componente qualitativo, já que, o problema no rural não é a escassez de solo, a estrutura do domicílio ou a regulação, mas sim, os costumes e a capacidade econômica dos moradores.

Adensamento excessivo em domicílio próprio / Hacinamiento no recuperable en vivienda propia

O Brasil estabelece uma distinção: o "adensamento excessivo de domicílios alugados" - Déficit Quantitativo -, e o "adensamento excessivo de domicílio próprio" - Déficit Qualitativo -. Refere-se a quando o número médio de moradores do domicílio próprio por cômodo é acima de três e que usam o cômodo como dormitório de forma permanente ${ }^{32}$.

\section{Adensamento por quarto, recuperável / Hacinamiento por cuarto, mitigable}

O Equador, o Peru e a Nicarágua não cruzam os dados para obter o índice de adensamento excessivo e do mitigável, no entanto, dados em suas Encuestas de Hogares permitem deduzir resultados sobre essa variável.

\section{viii) Posse da moradia e do solo / Tenencia de la vivienda y el terreno}

Classificação das moradias e do solo segundo a situação legal-jurídica ou o fato pelo qual os ocupantes habitam no domicílio.

Inadequação fundiária urbana / Irregularidad e ilegalidad en la tenencia del terreno y/o de la vivienda

A inadequação fundiária urbana, aplicada só no Brasil, é o caso "[...] em que pelo menos um dos moradores do domicílio tem a propriedade da moradia, mas não possui total, ou parcialmente, o terreno ou a fração ideal de terreno (no caso de apartamento) em que aquela se localiza" (FUNDAÇÃO JOÃO PINHEIRO, 2005, p. 9). O termo fundiário - relativo a terrenos - não tem tradução literal para o espanhol como termo afim ao que significa em português.

32 O Déficit Habitacional para o Brasil estipula um cômodo como "todos os compartimentos integrantes do domicílio separados por paredes, inclusive banheiros e cozinha, e os existentes na parte externa do prédio, desde que constituam parte integrante do domicílio. Não são considerados os corredores, alpendres, varandas abertas e outros compartimentos utilizados para fins não residenciais, como garagens, depósitos etc." (FUNDAÇÃO JOÃO PINHEIRO, 2013a, p. 22). 
Tipo de posse da moradia ou do solo / Tipo de tenencia de la vivienda y del terreno Refere-se ao tipo de posse da moradia ou do solo no qual esses se localizam. Os países da América Latina levantam dados sobre a posse da moradia ou do solo, seja nos Censos de População e Moradia, nas Encuestas de Hogares ou em outros censos; mas não é uma variável do Déficit Qualitativo, com exceção do Brasil. É um dado que ainda não se relaciona com a habitabilidade ou com a segurança da posse, para diminuir o risco de deslocamento ou de remoção forçada sem compensação.

\subsection{Variáveis de Déficit Habitacional e Elementos da Moradia Adequada do Pidesc de 1991}

O Pacto Internacional dos Direitos Econômicos, Sociais e Culturais (Pidesc) de 1991 busca que a Moradia Adequada seja avaliada desde sete elementos. O Pidesc é relevante porquanto desde essa data, agências multilaterais como UNHábitat avaliam desde seus sete elementos o grau de moradia adequada dos países; assim como algumas das nações da América Latina, o incorporam a seu sistema jurisprudencial e a suas medições habitacionais para estabelecer avanços no cumprimento ao direito à moradia adequada e na diminuição dos déficits habitacionais respectivamente. A seguir, uma comparação dos sete elementos do indicador do Pidesc de 1991, com as variáveis habitacionais em estudo, cujo fim é revisar a concordância entre os dois âmbitos.

(i) Segurança da posse. Essa variável pode ser encontrada sob denominações em espanhol como "tenencia de la vivienda", "forma de adquisición de la vivienda", "ocupación de la vivienda". Busca visibilizar assuntos de posse, assim como instaurar a segurança da posse em domicílios improvisados, em ruina por desastre ou por deslocamento por violência; assim como os critérios de indenização que estão por ser resolvidos desde as agências multilaterais e desde os países em estudo. Os indicadores habitacionais da América Latina não aplicam variáveis para visibilizar assuntos de posse, com exceção do Brasil, com a variável "inadequação fundiária". Mas os censos de população levantam dados sobre a posse.

(ii) Disponibilidade de serviços, materiais, instalações e infraestrutura. Segundo o Pidesc, refere-se ao acesso físico a serviços básicos, como água potável, saneamento, eliminação de dejetos, instalações sanitárias, gás; outros serviços associados ao conforto (iluminação, ventilação, calefação); além do acesso a serviços urbanos. Sobre a disponibilidade de serviços básicos, é uma variável verificada em todos os países, mas somente como conexão à rede para cada domicílio. Em outras palavras, o domicílio bem poderia apresentar disponibilidade de serviços básicos, mas isso não significa que o grupo ocupante esteja 
recebendo um serviço básico com qualidade, fazendo uso dele, utilizando uma conexão legal ou tendo a capacidade de pagamento das dívidas. Deste modo, vários assuntos não são identificados pelas nações em estudo: a qualidade e a constância no fornecimento de um serviço básico, o uso que os usuários fazem do serviço, a legalidade na conexão, o conhecimento e a capacidade de pagamento pelos usuários dos serviços e das dívidas.

(ii) Economicidade. O Pidesc apresenta que este elemento pode ser relacionado com gasto proporcional à renda, com o acesso a subsídios e outras formas de financiamento. Tem a ver com as variáveis de "hogar convivente dependente ou independente no econômico", "ônus excessivo com aluguel" e com "cômodo cedido ou alugado", que relacionam a renda do grupo familiar morador nas variáveis seguintes: "domicílio destruído por desastre natural", "domicílio em risco", "inadequação fundiária", "acesso a serviços básicos"; porquanto o financiamento relaciona-se com o acesso econômico à moradia nova, melhorias, manutenção e impostos do domicílio; com o pagamento de serviços básicos; com as dívidas para legalizar a posse; elementos não considerados no Déficit Habitacional das nações em estudo.

(iv) Habitabilidade. Refere-se ao domicilio com espaço adequado, de boa estrutura e de material durável, protetor contra vetores de doenças e inclemências do clima, propício à privacidade e à intimidade. Essas características estão contempladas nos indicadores de "Moradia Saudável" da Organização Mundial da Saúde $(\mathrm{OMS})^{33}$, e que o Pidesc busca que sejam atingidos. As variáveis associadas a esses tópicos são levantadas com profusão e incluídas com detalhes nos censos de população, mas em poucos casos como indicadores de habitação.

(v) Acessibilidade econômica. Alude à possibilidade de aquisição econômica do domicílio, do solo e da segurança da posse para grupos em desvantagem, para vítimas de desastres, para deslocados por violência, por guerras ou por projetos de desenvolvimento. Sobre a (iii) economicidade e (v) acessibilidade econômica; não é aplicada nenhuma variável a respeito desses dois elementos, desde os indicadores de habitação para a América Latina. Dados associados a esses elementos do Pidesc são empregados pelos países em estudo para a política socioeconômica ou de saúde.

\footnotetext{
${ }^{33}$ A "Moradia Saudável" invocada no Pidesc de 1991 é como segue: "El Comité exhorta a los Estados Partes a que apliquen ampliamente los Principios de Higiene de la Vivienda preparados por la OMS [Organización Mundial de la Salud], que consideran la vivienda como el factor ambiental que con más frecuencia está relacionado con las condiciones que favorecen las enfermedades en los análisis epidemiológicos; [...]" (COMITÉ DE DERECHOS ECONÓMICOS, SOCIALES Y CULTURALES, 1991, p. parágrafo 8d). Sobre os Principios de la Vivienda Saludable da Organización Mundial de la Salud (OMS) de 1990, ver Nota de Rodapé №.12 e (ORGANIZACIÓN MUNDIAL DE LA SALUD, 1990)
} 
(vi) Localização adequada. O Pidesc estabelece que se atinja à localização das áreas residenciais com acesso ao emprego, mobilidade, transporte, serviços de saúde, escolas e outros serviços sociais; assim como lugares residenciais não poluídos. Sobre esses itens, uma situação similar ocorre com o elemento "disponibilidade de serviços urbanos, materiais, infraestrutura". Dados sobre o acesso e a qualidade dos serviços urbanos e de áreas sem contaminação, encontram-se nas Encuestas de Hogares e de Condições de Vida de alguns países, e são utilizados para viabilizar projetos de cidade. $O$ acesso a serviços urbanos e às áreas não poluídas não são consideradas variáveis habitacionais pelos países em estudo.

(vii) Adequação cultural. O Pidesc indica que é a expressão da identidade cultural e o acesso aos serviços tecnológicos. É o elemento menos desenvolvido pelo Pidesc de 1991, por instituições que trabalham sobre os direitos habitacionais, por indicadores nacionais, e, do mesmo modo, por autores jurídicos e acadêmicos. Há ausência total de medição desse indicador na América Latina. Isso pode ser observado quando os indicadores do Déficit Habitacional não levantam dados, por exemplo, sobre as configurações familiares existentes, sobre a origem e destino das famílias, suas necessidades particulares, sobre os serviços tecnológicos. Alguns países elevam dados a respeito nos censos de população e nas Encuestas de Hogares e de Condições de Vida, mas com independência do Déficit Habitacional.

Sobre a invocação da Moradia Saudável no elemento (iv) Habitabilidade do Pidesc, e mais outras invocações referidas à relação habitação-saúde, nesse e em outros indicadores de moradia nacionais, a WHO relata que padrões de habitação são quase exclusivamente baseados em normas técnicas, conhecimento do campo da engenharia, e assuntos estéticos do design arquitetônico. Em consequência, padrões de "adequate housing" e "sustainable housing" são informados através de assuntos tecnológicos ao invés de justificativas sobre a saúde humana, apesar do fato de que muitas regulações de habitação têm sua origem em questões de saúde pública. $\mathrm{Da}$ mesma forma "buildings to be safe" são estipulados quando, por exemplo, se estabelecem adequadas condições de ventilação ou de ar condicionado, o que pouco diz sobre os padrões mínimos de saúde de um domicílio, e sobre as características que se precisam para fornecer moradia adequada na perspectiva da saúde humana (WORLD HEALTH ORGANIZATION, 2010, p. 3).

\subsection{A "Moradia Adequada" desde os Indicadores de Habitação dos países da América Latina, como produção estatística. Síntese}

As Nações Unidas como instituição que dá origem às variáveis e indicadores de habitação para os países da América Latina buscou instaurar desde a década de 
1950 um standard de vida mínimo configurado pelos seguintes componentes: saúde, nutrição, moradia, condições de emprego e educação. Na década seguinte, este standard de vida se tornou um conjunto de necessidades básicas composto por alimentação, abrigo, vestuário, equipamentos domésticos, serviços essenciais; que só podia ser atingido a partir de uma remuneração adequada. Esse conjunto de necessidades básicas seria considerado a partir de variáveis, estipuladas no documento guia das Naciones Unidas (1961).

O conjunto de componentes e variáveis do standard de vida da década de 1950, que mudou nos dois decênios seguintes para o conjunto de necessidades básicas, são hoje variáveis dos indicadores de habitação nacionais, do indicador de Hogar de Assentamentos Precários dos Objetivos de Desenvolvimento do Milênio (ODM) de 2000, e fazem parte dos elementos da Moradia Adequada do Pacto Internacional de Direitos Econômicos, Sociais e Culturais (PIDESC) de 1991. O denominador comum de todos esses períodos e indicadores é a noção de "necessidades básicas", que, é aplicado como Indicador de Necessidades Básicas Insatisfeitas (NBI) para a América Latina e O Caribe desde meados da década de 1970.

Uma análise sob os Métodos Direto e da Renda, os quais avaliam indicadores de condições de vida, mostra que o conjunto de necessidades básicas, como a moradia e os serviços básicos, refere-se é a bens e serviços duráveis, ou nas palavras de Sen (1992), como necessidades de bens. Deste modo, as variáveis de habitação são características desses bens e serviços, além de instituídas como carências residenciais, pelo qual se estabelecem como o mínimo a ser garantido como um indicador de habitação, e são o conteúdo material do direito à moradia. Deste modo, o habitante o que busca não é ter tantas necessidades de bens, e sim necessidades de características, razão pelo qual escolhe as variáveis habitacionais que possam ser cobertas com a sua capacidade econômica; em outras palavras, decide com quais carências habitacionais irá morar.

Assim, o que mostram os diagnósticos residenciais são deficiências em características dos bens e serviços de um conjunto de população. De tal modo, se o grupo familiar não atinge algum desses mínimos, expõe carências residenciais, e a qualidade de sua vida ressente com isso. A necessidade de características é o que, conforme AñonRoig, é necessária para a sobrevivência ou para a qualidade de vida; a não-satisfação de necessidades de características, pode causar deterioração, destruição ou nãoexistência de um ser humano (1994, p. 165).

Os países da América Latina, vistos desde os indicadores de habitação, consideram que a moradia adequada é um diagnóstico constituído pelas variáveis do Déficit Habitacional, do Indicador NBI, do Indicador de Moradia Adequada do Pidesc de 1991, cuja base destes indicadores é um conjunto de necessidades básicas. O diagnóstico 
o que avalia é à população com carência nas características (variáveis) que compõem a moradia e os serviços básicos, sendo estes considerados bens e serviços duráveis.

Os indicadores de habitação tomam os dados das variáveis dos censos de população e moradia, mas não todo o conjunto de necessidades básicas, apenas um grupo que permita avaliar a política social; pelo qual, esses indicadores expressam apenas algumas deficiências de habitação, o que não reflete a singularidade de cada país em consideração a necessidades específicas residenciais. Surge o questionamento sobre as outras insuficiências residenciais que não são tidas em conta nos indicadores, e que ainda são pouco pesquisadas; como consequência, as famílias que não apresentam deficiências de acordo com os indicadores nacionais, são consideradas pelos agentes públicos que constroem diagnósticos residenciais, que vivem em uma moradia adequada.

O indicador do déficit habitacional é insumo básico e indispensável para o desenvolvimento das políticas de habitação, toda vez que ele fornece não somente um diagnóstico inicial, mas também uma base para a concepção, implementação, monitoramento e avaliação dos resultados e impactos de seus vários componentes e estratégias. ONU-Hábitat afirma que ao considerar que as políticas sociais são projetadas para resolver um problema que é limitado e mensurável, o déficit habitacional é provavelmente a ferramenta mais adequada para descrever e quantificar o volume das necessidades específicas que uma política de habitação deve atender para garantir o acesso da população à moradia adequada (2015).

Os sistemas de indicadores urbanos e de habitação têm, portanto, condições de serem aperfeiçoados, e, mesmo que na região existam desigualdades em quanto aos sistemas para recopilação de dados, é uma oportunidade para visibilizar outras carências nos territórios degradados, que poderiam ser estabelecidas como um "mínimo" que não pode ser negociável nos assuntos de habitabilidade das áreas residenciais e, em consequência, nos direitos habitacionais.

A seguir, na Figura 2.1 apresentamos em um paralelo, desde a criação da ONU, a evolução da noção "Moradia Adequada" nos instrumentos internacionais de direitos humanos relacionados com a habitação, e a evolução dos indicadores de habitação, para desvendar que, desde o início, o conjunto de necessidades básicas estabelecido pela ONU é configurado por alimentação, abrigo, vestimenta, equipamentos domésticos e serviços básicos, os quais têm a ver com bens e serviços duráveis. As variáveis desses bens constituem-se em suas características, que, por sua vez, são o suporte para estabelecer o déficit a respeito desses componentes. Para o caso da moradia, as variáveis de habitação são as características desse bem durável, e, consequentemente, o suporte do déficit habitacional dos países da América Latina. 
A Figura 2.1 está composta por dois campos: 1) a evolução da noção "moradia adequada", e 2) a evolução dos indicadores de moradia. Para explicar a Figura, tomemos os elementos da Declaração Universal dos Direitos do Homem (DUDH) de 1948, do primeiro campo. Na noção "Moradia Adequada", o abrigo para a DUDH é uma característica que, desde essa própria Declaração, busca-se manter como uma carência, a partir de bens como a moradia. Contudo, a habitação, tida como um bem, só é um meio para atingir o "direito ao nível de vida adequado". No segundo campo que se refere à evolução dos indicadores de moradia, as variáveis de habitação são consideradas carências porque sua base são padrões regulamentados; essas variáveis são características de bens duráveis como a moradia e os serviços básicos que se tornam para os programas de ação como um meio, para aplicar políticas habitacionais como um fim. Posto isso, o habitante o que busca não é suprir tantas necessidades de bens, e sim características de bens, o quanto sua renda possa sustentar, razão pelo que faz escolhas sobre quais variáveis atingir segundo a sua capacidade econômica, porque a moradia está pensada para ser alcançada através de um valor econômico. 


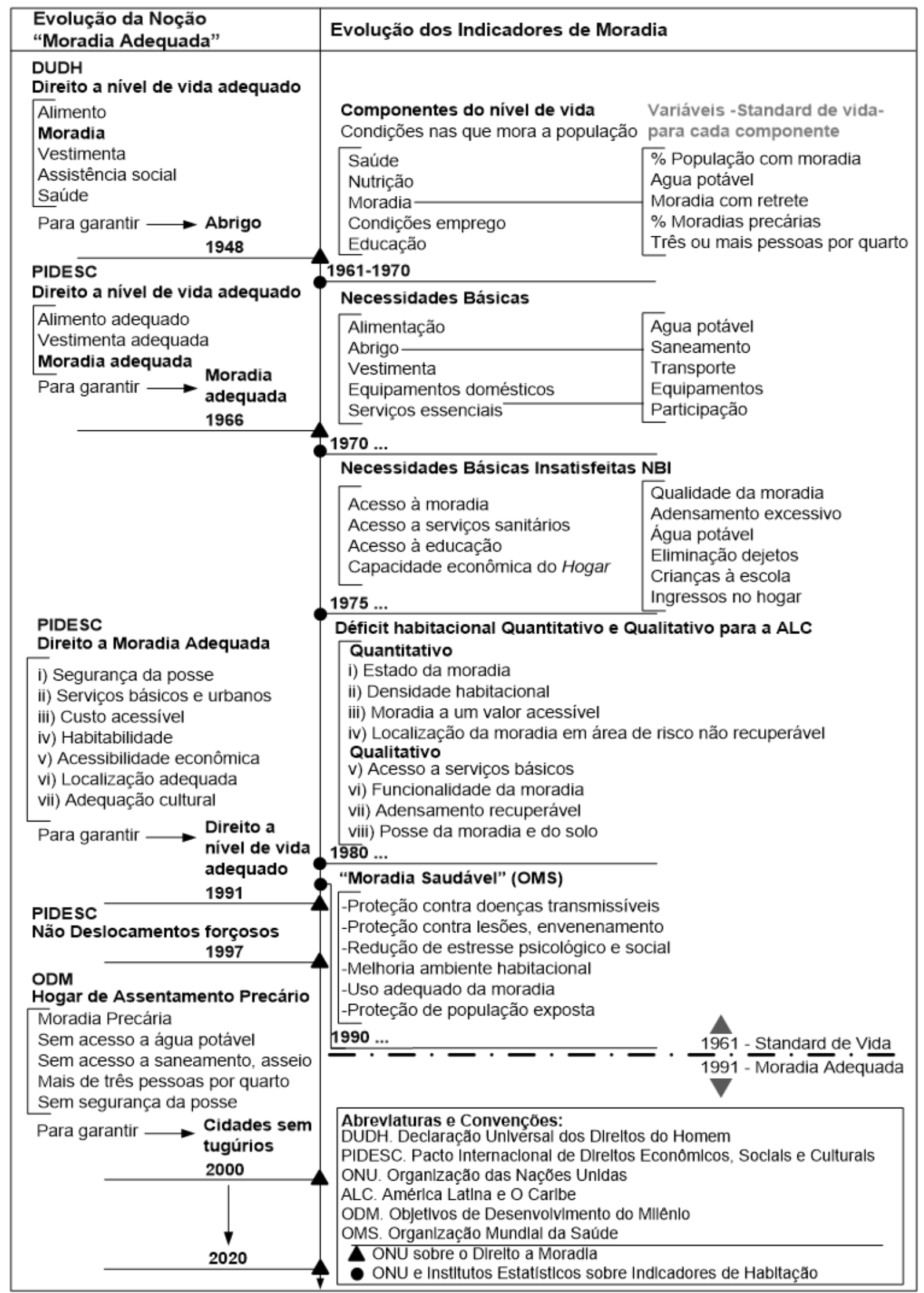

Figura 2.1 - Paralelo entre a evolução da noção de moradia adequada da ONU e corpos anexos, e os indicadores de habitação

Fonte: (MEJÍA-ESCALANTE, 2015, p. 173). Adicionamos à Figura original, as variáveis de "Moradia Saudável" da OMS. 


\section{Capítulo 3}

\section{ADJETIVAÇÕES À MORADIA NAS CONSTITUIÇÕES DOS PAÍSES DA AMÉRICA LATINA E O MÍNIMO DOS DIREITOS HABITACIONAIS ${ }^{34}$}

\subsection{Introdução}

As Constituições dos países da América Latina qualificam a moradia, os serviços básicos e o ambiente como um direito e com diversos adjetivos: adequado, digno, inviolável, higiênico, seguro, decoroso, decente. Pisarello (2003) expressa que todo direito, pelo fato de estar na Carta Constitucional de um país, goza de um conteúdo básico que é admitido como o "mínimo", o qual consiste em uma prerrogativa que nenhuma autoridade pública pode deixar de satisfazer.

Ele continua argumentando que para o componente objetivo do direito à moradia - o que chamamos neste Capítulo como "o mínimo dos direitos habitacionais"- é necessário adotar indicadores que possam ser usados como parâmetro para distinguir, por exemplo, se o não cumprimento das obrigações de um Estado no campo dos direitos habitacionais, pode ser atribuída à falta de capacidade ou de vontade; ou para estabelecer se uma nação produziu, em um período de tempo, as situações de regressão, estagnação ou de progresso insuficiente na aplicação da política de habitação.

${ }^{34}$ Capítulo apresentado quase em sua totalidade nos anais do Congresso " $3^{\circ} \mathrm{CIHEL}$ - Congresso Internacional da Habitação no Espaço Lusófono: Portugal, Brasil, Timor Leste, Moçambique, Macau, Cabo Verde, Angola, São Tomé e Príncipe, Guiné-Bissau, Guiné Equatorial"; com artigo da (ESCALANTE, 2015) publicado nos anais do evento com título: "Variáveis de habitação e adjetivações à moradia. O mínimo dos direitos habitacionais". Congresso realizado na Universidade de São Paulo, Brasil, nas datas de setembro 7, 8, 9 de 2015. O conteúdo deste Capítulo tem algumas variações com o artigo publicado nos anais, para se adaptar às indicações da Universidade de São Paulo como tese de doutorado. Duas grandes variações entre este Capítulo e o artigo publicado nos anais do evento: 1) neste capítulo não foram visualizadas as variáveis de habitação dos países da América Latina, o que foi feito no Capítulo 2 desta tese e no artigo publicado nos anais, e 2) neste Capítulo não foi incluída a revisão das Constituições dos países lusófonos a respeito das adjetivações à moradia, o qual foi feito no artigo publicado nos anais do congresso referido. 
Ao examinar os Indicadores de Habitação dos países da América Latina, analisados no Capítulo 2, as variáveis que diagnosticam o estado da moradia e os serviços básicos são comuns a essas nações; no entanto, não refletem como cada Constituição qualifica a habitação. A revisão das Cartas Políticas para verificar como cada país qualifica a moradia, os serviços básicos e o ambiente apoia o propósito deste capítulo de revisar a coerência entre as expressões encontradas nas Constituições e nos Indicadores de Habitação e a de desvendar que as variáveis de habitação podem ser consideradas o mínimo dos direitos habitacionais.

Neste Capítulo mostramos os critérios de abordagem para a leitura das Constituições de 21 países da América Latina, para logo expor as diversas adjetivações dadas à moradia em cada uma destas Cartas Políticas. No final abalançamos uma síntese sobre o que é que poderia ser considerado o conteúdo material e objetivo dos direitos habitacionais.

\subsection{Constituições dos países da América Latina. Abordagem metodológica}

As Constituições dos seguintes países da América Latina foram examinadas: Argentina, Bolívia, Brasil, Colômbia, Costa Rica, Chile, Cuba, Equador, El Salvador, Guatemala, Haiti, Honduras, México, Nicarágua, Panamá, Paraguai, Peru, Porto Rico, República Dominicana, Uruguai e Venezuela.

Revisamos as qualificações à moradia, aos serviços básicos e ao ambiente instauradas nas Constituições dos países referidos, e que estão disponíveis nos sites institucionais de governo de cada nação. As palavras de busca em cada Carta Magna foram: casa, domicílio, habitação, moradia; e suas equivalentes em espanhol: casa, domicilio, habitación, hogar, morada, recinto, vivienda.

Assim, as adjetivações à moradia encontradas são diversas: adecuada, barata, cómoda, confortable, decente, decorosa, digna, de interés social, un derecho, económica, inviolable, popular, que garantice la privacidad familiar, sagrada, con servicios básicos esenciales que incluyan un hábitat que humanice las relaciones familiares, vecinales y comunitarias, um direito social.

\subsection{Adjetivações à moradia nas Constituições}

As Constituições dos países da América Latina instauram a moradia como um direito social, mas também a qualificam a partir de adjetivações. El Salvador, o Equador, a Guatemala, Honduras, o México, o Peru, a República Dominicana e a Venezuela instituem a moradia e o ambiente adequado nas suas Cartas Políticas; 
enquanto que para a Argentina, a Colômbia, o Equador, Honduras, México, a Nicarágua, o Paraguai e a República Dominicana é a moradia digna. Na Nicarágua, é digna, confortável, segura, e que garanta a privacidade. Na República Dominicana, moradia digna é definida como aquela que possui os serviços básicos essenciais. $A$ Venezuela a qualifica como adequada, segura, confortável e higiênica. Para o Haiti, é decente. Para Cuba, é confortável. A moradia decorosa é instituída no México e Uruguai.

O Peru elimina o reconhecimento constitucional do direito à moradia decorosa e, no ano 2000, só fica com a inviolabilidade da moradia. A inviolabilidade do domicílio é reconhecida em todos os países da América Latina com exceção do Haiti, de El Salvador, do Paraguai e de Porto Rico. A Guatemala e o Uruguai são os países que se referem a grupos minoritários; o primeiro estabelece para as comunidades indígenas a proteção dos seus territórios; o Uruguai menciona o abrigo para moradores de rua ou pessoas com deficiência física ou mental não habilitados para o trabalho. A Costa Rica, El Salvador, a Guatemala e o México determinam que, para o trabalhador, sejam os domicílios higiênicos e confortáveis. Porto Rico menciona apenas o direito à moradia, sem qualificá-la. O Brasil qualifica a moradia como um direito social e como asilo inviolável do indivíduo. No Quadro 3.1 podemos observar as adjetivações à moradia nas Constituições dos países da América Latina, e o ano de adesão ao Pidesc.

\begin{tabular}{|c|c|c|}
\hline $\begin{array}{l}\text { País e ano da } \\
\text { Constituição }\end{array}$ & $\begin{array}{l}\text { Adjetivação dada à Moradia (no idioma original) e Artigo na } \\
\text { Constituição }{ }^{35}\end{array}$ & $\begin{array}{l}\text { Ano de } \\
\text { adesão ao } \\
\text { Pidesc }^{36}\end{array}$ \\
\hline \multirow{3}{*}{ Argentina, 1994} & Vivienda digna (14 bis) & \multirow{3}{*}{$\begin{array}{l}\text { 1986, } \\
\text { ratificação }\end{array}$} \\
\hline & Domicilio inviolable (18) & \\
\hline & Medio ambiente libre de contaminación (41) & \\
\hline \multirow{2}{*}{ Bolívia, 2004} & Toda casa es un asilo inviolable (21) & \multirow{2}{*}{$\begin{array}{l}1982, \\
\text { adesão }\end{array}$} \\
\hline & Vivienda de interés social $(158,206)$ & \\
\hline
\end{tabular}

35 Constituições dos Países da América Latina consultadas: (ARGENTINA. CONSTITUCIÓN [1994]); (BOLIVIA. CONSTITUCIÓN [2004]); (BRASIL. CONSTITUIÇÃO [1988]); (COLOMBIA. CONSTITUCIÓN [1991]); (COSTA RICA. CONSTITUCIÓN [1949]); (CUBA. CONSTITUCIÓN [1992]); (CHILE. CONSTITUCIÓN [2005]); (ECUADOR. CONSTITUCIÓN [2008]); (EL SALVADOR. CONSTITUCIÓN [1983]); (GUATEMALA. CONSTITUCIÓN [1993]); (HAITÍ. CONSTITUCIÓN [1987]); (HONDURAS. CONSTITUCIÓN [1982]); (MÉXICO. CONSTITUCIÓN [1917]); (NICARAGUA. CONSTITUCIÓN [2003]); (PANAMÁ. CONSTITUCIÓN [2004]); (PARAGUAY. CONSTITUCIÓN [1992]); (PERÚ. CONSTITUCIÓN [1993]); (PUERTO RICO. CONSTITUCIÓN [1952]); (REPÚBLICA DOMINICANA. CONSTITUCIÓN [2010]); (URUGUAY. CONSTITUCIÓN [1967]); (VENEZUELA. CONSTITUCIÓN [1999]).

${ }^{36}$ As datas da adesão ao Pidesc dos países da América Latina apresentados no Quadro 3.1, com fonte em (UNITED NATIONS, 2015). O Pidesc é de relevância para o tema deste Capítulo, porquanto os países que o ratificaram estão comprometidos juridicamente a cumprir com as obrigações detalhadas na convenção, para o particular, com o cumprimento do direito à moradia adequada. Mais informação sobre termos como adesão, ratificação e assinado, pode-se consultar o glossário da ONU em www.un.org/es/treaty/glossary.shtml. [Online a fevereiro de 2014]. 


\begin{tabular}{|c|c|c|}
\hline $\begin{array}{l}\text { País e ano da } \\
\text { Constituição }\end{array}$ & $\begin{array}{l}\text { Adjetivação dada à Moradia (no idioma original) e Artigo na } \\
\text { Constituição }\end{array}$ & $\begin{array}{l}\text { Ano de } \\
\text { adesão ao } \\
\text { Pidesc }^{36}\end{array}$ \\
\hline \multirow{3}{*}{ Brasil, 1988} & A casa é asilo inviolável do indivíduo (5) & \multirow{3}{*}{$\begin{array}{l}1992, \\
\text { adesão }\end{array}$} \\
\hline & $\begin{array}{l}\text { São direitos sociais a educação, a saúde, a alimentação, o trabalho, a } \\
\text { moradia, o lazer [...] (6) }\end{array}$ & \\
\hline & Meio ambiente ecologicamente equilibrado (225) & \\
\hline \multirow{3}{*}{ Colômbia, 1991} & Ni su domicilio registrado (inviolable) (28) & \multirow{3}{*}{$\begin{array}{l}1969, \\
\text { ratificação }\end{array}$} \\
\hline & Vivienda digna. Vivienda de Interés Social (51) & \\
\hline & Ambiente sano (79) & \\
\hline \multirow{3}{*}{ Costa Rica, 1949} & Domicilio y todo otro recinto privado son inviolables (23) & \multirow{3}{*}{$\begin{array}{l}1968, \\
\text { ratificação }\end{array}$} \\
\hline & Viviendas populares para el trabajador (65) & \\
\hline & Ambiente sano y ecológicamente equilibrado (50) & \\
\hline \multirow{2}{*}{ Cuba, 1992} & Vivienda confortable (9) & \multirow{2}{*}{$\begin{array}{l}2008, \\
\text { assinado }\end{array}$} \\
\hline & El domicilio es inviolable (56) & \\
\hline \multirow{2}{*}{ Chile, 2005} & Inviolabilidad del hogar (19). Sus recintos son inviolables (75) & \multirow{2}{*}{$\begin{array}{l}1972, \\
\text { ratificação }\end{array}$} \\
\hline & Medio ambiente libre de contaminación (19) & \\
\hline \multirow{4}{*}{ Equador, 2008} & $\begin{array}{l}\text { Vivienda adecuada, con facilidades de acceso y condiciones necesarias } \\
\text { para atender su discapacidad [do morador] y para procurar el mayor grado } \\
\text { de autonomía en su vida cotidiana ( } 47)\end{array}$ & \multirow{4}{*}{$\begin{array}{l}1969, \\
\text { ratificação }\end{array}$} \\
\hline & Vivienda digna, de interés social (375) & \\
\hline & Inviolabilidad del domicilio $(66,165,355)$ & \\
\hline & $\begin{array}{l}\text { Ambiente sano, ecológicamente equilibrado, que garantice la sostenibilidad } \\
\text { y el buen vivir (14); ecológicamente equilibrado, libre de contaminación y en } \\
\text { armonía con la naturaleza }(66,397) \text {. }\end{array}$ & \\
\hline \multirow{3}{*}{ El Salvador, 1983} & Habitaciones adecuadas para el trabajador (51) & \multirow{3}{*}{$\begin{array}{l}1979, \\
\text { ratificação }\end{array}$} \\
\hline & $\begin{array}{l}\text { De interés social la construcción de viviendas. Que todo propietario de fincas } \\
\text { rústicas proporcione a los trabajadores residentes habitación higiénica y } \\
\text { cómoda (119) }\end{array}$ & \\
\hline & La morada es inviolable (20) & \\
\hline \multirow{4}{*}{ Guatemala, 1993} & Inviolabilidad de la vivienda (23) & \multirow{4}{*}{$\begin{array}{l}1988, \\
\text { adesão }\end{array}$} \\
\hline & $\begin{array}{l}\text { Protección de la tierra y de la vivienda popular de las comunidades } \\
\text { indígenas }(66,67)\end{array}$ & \\
\hline & $\begin{array}{l}\text { Vivienda adecuada para los trabajadores y que llenen las condiciones de } \\
\text { salubridad (105) }\end{array}$ & \\
\hline & Vivienda popular (118) & \\
\hline Haiti, 1987 & Vivienda decente (22) & $\begin{array}{l}\text { Haiti, sem } \\
\text { assinar }\end{array}$ \\
\hline \multirow{3}{*}{ Honduras, 2005} & El domicilio es inviolable (99) & \multirow{3}{*}{$\begin{array}{l}1981, \\
\text { ratificação }\end{array}$} \\
\hline & Vivienda digna. Vivienda de Interés Social (178) & \\
\hline & Medio ambiente adecuado (145) & \\
\hline \multirow{4}{*}{ México, 1917} & Nadie puede ser molestado en su domicilio (inviolable) (16) & \multirow{4}{*}{$\begin{array}{l}1981, \\
\text { adesão }\end{array}$} \\
\hline & Vivienda digna y decorosa (4) & \\
\hline & $\begin{array}{l}\text { Toda empresa está obligada a garantizar habitación barata, cómoda e } \\
\text { higiénica para los trabajadores (123) }\end{array}$ & \\
\hline & Medio ambiente adecuado (4) & \\
\hline \multirow{3}{*}{ Nicarágua, 2003} & Inviolabilidad del domicilio (28) & \multirow{3}{*}{$\begin{array}{l}1980, \\
\text { adesão }\end{array}$} \\
\hline & Vivienda digna, cómoda y segura que garantice la privacidad familiar (64) & \\
\hline & Habitar en un ambiente saludable & \\
\hline \multirow{3}{*}{ Panamá, 2004} & Domicilio o residencia son inviolables (26) & \multirow{3}{*}{$\begin{array}{l}1977, \\
\text { ratificação }\end{array}$} \\
\hline & Vivienda como derecho social (117) & \\
\hline & Ambiente sano y libre de contaminación (118) & \\
\hline \multirow{2}{*}{ Paraguai, 2002} & Vivienda digna. Vivienda de Interés Social (100) & \multirow{2}{*}{$\begin{array}{l}\text { 1992, } \\
\text { adesão }\end{array}$} \\
\hline & Ambiente saludable y ecológicamente equilibrado (7) & \\
\hline
\end{tabular}




\begin{tabular}{|c|c|c|}
\hline $\begin{array}{l}\text { País e ano da } \\
\text { Constituição }\end{array}$ & $\begin{array}{l}\text { Adjetivação dada à Moradia (no idioma original) e Artigo na } \\
\text { Constituição }\end{array}$ & $\begin{array}{l}\text { Ano de } \\
\text { adesão ao } \\
\text { Pidesc }^{36}\end{array}$ \\
\hline & Todo recinto privado es inviolable (34) & \\
\hline \multirow{2}{*}{ Peru, 1993} & Inviolabilidad del domicilio $(2,137)$ & \multirow{2}{*}{$\begin{array}{l}1978, \\
\text { ratificação }\end{array}$} \\
\hline & Ambiente equilibrado y adecuado al desarrollo de su vida (2) & \\
\hline Porto Rico, 1952 & Derecho a la vivienda (Sesión 20) & Sem dados \\
\hline \multirow{3}{*}{$\begin{array}{l}\text { República } \\
\text { Dominicana, } 2010\end{array}$} & Vivienda digna con servicios básicos esenciales (59) & \multirow{3}{*}{$\begin{array}{l}1978, \\
\text { adesão }\end{array}$} \\
\hline & $\begin{array}{l}\text { Hogar, domicilio y todo recinto privado de la persona son inviolables (44, } \\
266 \text { ) }\end{array}$ & \\
\hline & Habitar en un ambiente sano, ecológicamente equilibrado y adecuado (67) & \\
\hline \multirow{3}{*}{ Uruguai, 1967} & Vivienda decorosa, higiénica y económica (45) & \multirow{3}{*}{$\begin{array}{l}1970, \\
\text { ratificação }\end{array}$} \\
\hline & El hogar es un sagrado inviolable (11) & \\
\hline & $\begin{array}{l}\text { Asilo a indigentes o carentes de recursos suficientes que, por su inferioridad } \\
\text { física o mental de carácter crónico, estén inhabilitados para el trabajo.(46) }\end{array}$ & \\
\hline \multirow{4}{*}{ Venezuela, 1999} & $\begin{array}{l}\text { Vivienda adecuada, segura, cómoda, higiénica, con servicios básicos } \\
\text { esenciales que incluyan un hábitat que humanice las relaciones familiares, } \\
\text { vecinales y comunitarias (82) }\end{array}$ & \multirow{4}{*}{$\begin{array}{l}1978, \\
\text { ratificação }\end{array}$} \\
\hline & El hogar doméstico y todo recinto privado de persona son inviolables (47) & \\
\hline & Vivienda de Interés Social (178) & \\
\hline & $\begin{array}{l}\text { Ambiente seguro, sano y ecológicamente equilibrado, libre de } \\
\text { contaminación (127) }\end{array}$ & \\
\hline
\end{tabular}

Quadro 3.1 - Adjetivação dada à moradia nas Constituições dos países da América Latina e ano de adesão ao Pidesc.

Fonte: (ESCALANTE, 2015).

\subsection{A "Moradia Adequada, Digna, Decente, Segura, Higiênica" nas Constituições dos países da América Latina e o mínimo dos direitos habitacionais. Síntese}

As variáveis de habitação apresentam uma estreita relação com as adjetivações à moradia instituídas nas Constituições dos países da América Latina. A moradia adequada e o ambiente adequado são constituídos como direito em oito das Cartas Políticas; no entanto, quase todos países em estudo incluem o indicador de Moradia Adequada do Pidesc de 1991, para estabelecerem diagnósticos residenciais. A moradia digna está instaurada em oito das Constituições dos países da América Latina, sendo invocada em diversos âmbitos da política urbana desse continente. Algumas Constituições estabelecem a moradia como um direito social, inclusive antes de se instaurar que a moradia adequada é um direito no Pidesc de 1991.

Chama a atenção que 19 das 21 Constituições revisadas instituem a inviolabilidade do domicílio, a qual tem certa afinidade com cuidar da privacidade e da intimidade na moradia, atos previstos apenas na Carta Política da Nicarágua. Assim, na revisão das qualificações à moradia nas Constituições e sua relação com as variáveis de habitação de cada país, há necessidades habitacionais comuns refletidas nas variáveis, e objetivos a se atingir, ajuizados nas Cartas Magnas. 
As qualificações nas Constituições como a moradia higiênica, confortável ou livre de contaminação, quando são definidas como carências, podem ser diagnosticadas a partir de variáveis que revisam a precariedade da moradia, os seus materiais, o acesso a serviços básicos, a posse de móveis domésticos e a disposição da cozinha ou de instalações sanitárias separadas das outras atividades do domicílio; não obstante, essas são as únicas variáveis dos indicadores de habitação da América Latina, que buscam diagnosticar a moradia desde o ponto de vista da higiene, ou do espaço livre de contaminação, e não todos os países as aplicam. Variáveis associadas com a privacidade correspondem as do hogar convivente ou que diagnosticam o adensamento, que bem poderiam revisar assuntos de privacidade e intimidade, mas o que realmente buscam essas variáveis são hogares que convivem com outros para determinar quantas unidades de moradia precisam ser construídas para diminuir o déficit quantitativo.

Uma única definição do direito à moradia digna, decorosa, segura ou higiênica é difícil, porque a cultura, a classe social, os interesses políticos e econômicos influenciam. No entanto, essa adjetivação da moradia nas Cartas Magnas, diferente da adequada, tem o potencial que poderia estar configurada por outras variáveis mais específicas a cada nação, e não só as consideradas universais como acontece com os elementos do "direito à moradia adequada" do Pidesc de 1991, tornando-se uma forma de governança das políticas de habitação.

Assim, a delimitação material e objetiva do direito à moradia, corresponde às variáveis de habitação de cada país, como o mínimo para ser considerado que um Estado deveria garantir e que um cidadão poderia exigir como direito à moradia. Ainda que a heterogeneidade habitacional seja tão vasta, que nem todas as deficiências podem refletir-se nas variáveis residenciais, o indicador de habitação detém esse papel fundamental de configurar o mínimo e o objetivo do direito à moradia, ou seja, o mínimo dos direitos habitacionais, para manter na categoria de direito as adjetivações dadas à habitação, contidas nas Cartas Políticas.

Na Figura 3.1 expomos um mapa com as variáveis de habitação que cada nação aplica. As fontes de informação para construir essa Figura 3.1 de elaboração própria, foram os institutos estatísticos dos 21 países da América Latina.

Na Figura 3.2 apresentamos um Mapa com as adjetivações à habitação que 21 países da América Latina estabelecem nas suas Constituições, como fonte de evidencia dos dados.

Na Figura 3.3 abalançamos, a modo de linha de tempo e em forma de compêndio dos âmbitos multilateral e institucional, os acontecimentos da ONU mais relevantes sobre moradia adequada; os problemas que a ONU estipulou, deveriam ser afrontados por 
período de tempo; os indicadores de habitação da ONU e dos países da América Latina em diversos momentos; as adjetivações à habitação dadas nas Constituições dos países da América Latina; a evolução da noção de moradia adequada.

Essa Figura 3.3 tem como base a Figura 1.1 da página 59, para observar que as variáveis de habitação não mudam desde que foram instauradas no documento Guia das Naciones Unidas de 1961 como indicadores prioritários e complementares para os componentes do nível de vida. Os acontecimentos da ONU respondem a problemas sobre moradia depois que estes são visualizados nos diagnósticos de habitação por vários anos. As variáveis de habitação, comuns aos países da América Latina, não expõem a adjetivação dada por cada nação na sua Constituição. No entanto, eis a importância dos indicadores habitacionais: um conjunto de variáveis, que consiste no mínimo a ser garantido como moradia adequada, ou seja, um conjunto que é o suporte objetivo e material do direito à moradia. 


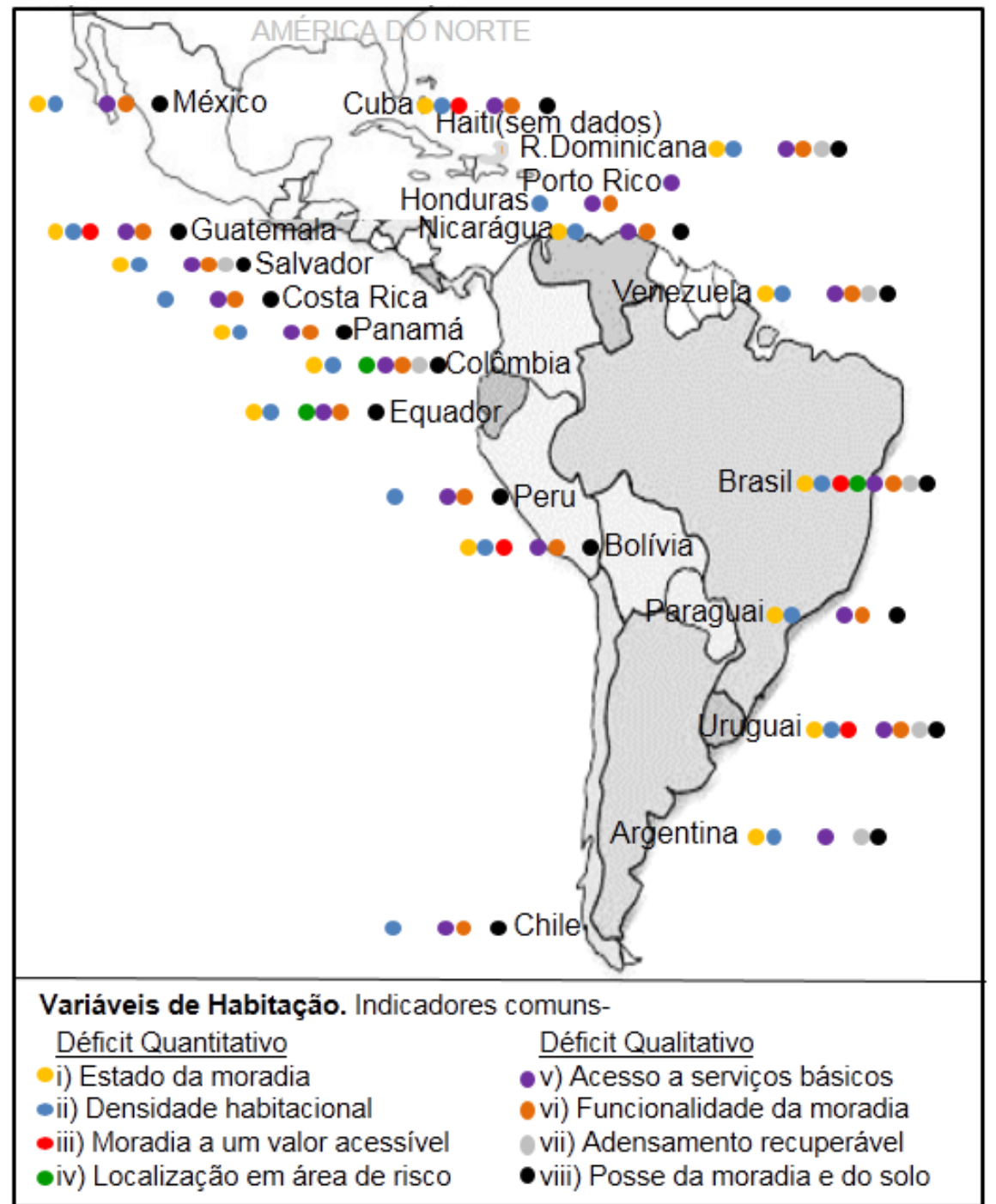

Figura 3.1 - Mapa com as variáveis de habitação que 21 países da América Latina aplicam.

Fonte: Elaboração própria. Ver Nota de Rodapé N"29 para as fontes de suporte.

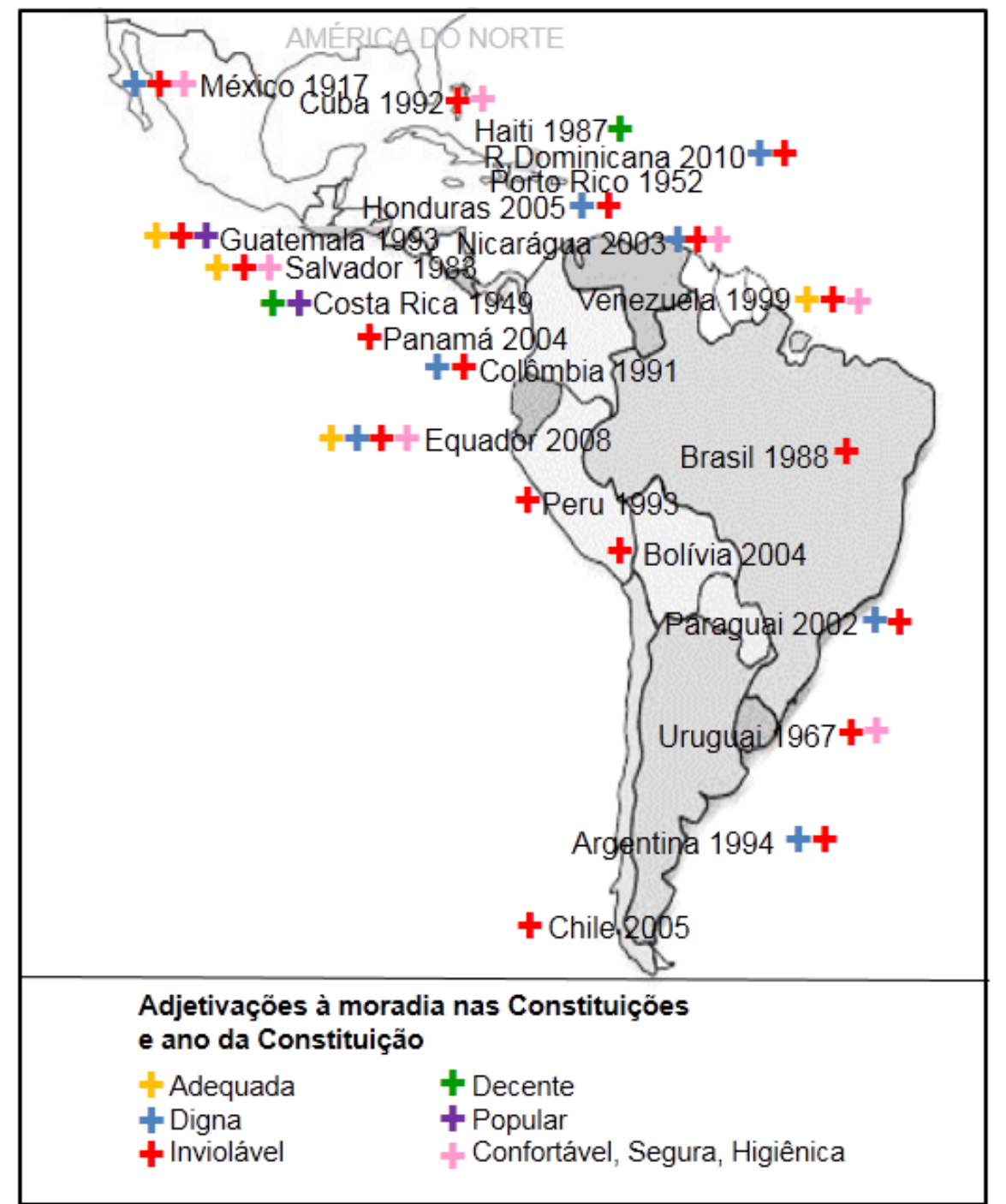

Figura 3.2 - Mapa com as adjetivações à moradia que a Constituição de cada pais da América Latina estabelece e ano da Constituição.

Fonte: Elaboração própria. Ver Nota de Rodapé N"35 para as fontes de suporte. 


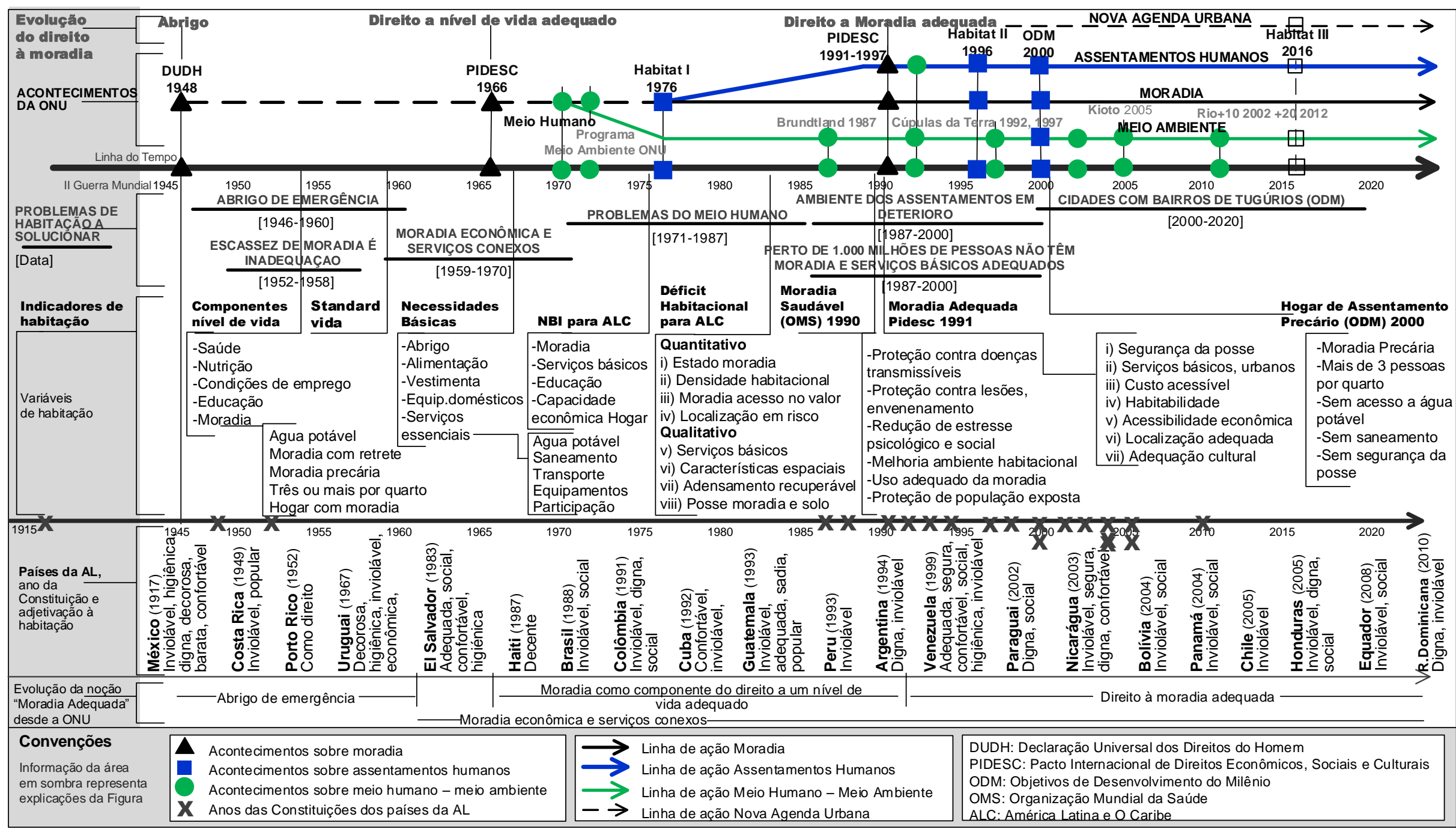

Figura 3.3 - Acontecimentos da ONU mais relevantes sobre moradia adequada; problemas de habitação a solucionar pela ONU, expostos por período; evolução dos indicadores de habitação e suas variáveis; adjetivações à habitação dadas nas Constituições de 21 países da América Latina, e a evolução da noção de moradia adequada desde a ONU. Compendio do âmbito multilateral e do institucional.

Fonte: elaboração própria. Essa Figura 3.3 tem como base a Figura 1.1 da página 59. 


\section{Capítulo 4}

\section{A MORADIA ADEQUADA E A MORADIA DIGNA. ESTADO DO DEBATE NA LITERATURA ACADÊMICA ${ }^{37}$}

\subsection{Introdução}

A produção acadêmica revela questões e abordagens que estão sendo pesquisadas no tema da moradia, mas observando um uso não diferenciado entre a "moradia adequada" e a "moradia digna"; bem como no âmbito multilateral e institucional, discutidos nos Capítulos 1, 2 e 3. O assunto de sua utlização indistinta é considerado importante porquanto a presunção é que, as noções em questão e outras expressões relacionadas, ainda que sejam termos equivalentes, não têm o mesmo abarcamento conceitual. Neste Capítulo efetuamos uma revisão da literatura nos grandes repositórios de documentação acadêmica do mundo, sob essas expressões em português, espanhol e inglês, com ferramentas cientométricas e de análise de conteúdo.

Este Capítulo está configurado pela abordagem metodológica de recopilação, classificação e leitura sistematizada da produção acadêmica, encontrada sob as expressões de pesquisa "moradia adequada" e "moradia digna", em grandes repositórios de produção escrita no mundo; para em seguida expor vertentes e temas descobertos nesta revisão bibliográfica, bem como os autores que pesquisam sobre habitação sob esses termos de busca. No final, algumas considerações sobre o debate atual no tema da moradia desde a produção acadêmica.

Nesta revisão emergiram três vertentes em que se move o debate sobre moradia a saber: i) a política habitacional, ii) o direito à habitação, iii) os espaços adequados para indivíduos com condições particulares físicas, mentais e de saúde. Ademais,

\footnotetext{
${ }^{37}$ Capítulo apresentado para a revista Cuadernos de Vivienda y Urbanismo da Colômbia, com o artigo intitulado "La vivienda digna y adecuada. Estado del debate", o qual está em processo de avaliação desde a data de 27/10/2015. O conteúdo deste Capítulo tem algumas variações com o artigo a ser publicado, para se adaptar às indicações da Universidade de São Paulo como tese de doutorado. $O$ artigo foi apresentado no idioma espanhol para sua avaliação.
} 
descobrimos que poucos autores abordam as expressões em questão; bem como outros que, no marco do direito, debatem sobre a moradia, e mais alguns que, localizados na última vertente, enunciam que a dignidade deve ser compreendida em sua dimensão prática para ser observada.

\subsection{A produção acadêmica sobre a questão da moradia. Abordagem metodológica}

Existem várias maneiras de avaliar a tendência da ciência e da informação, tais como a bibliometria, a cientometria, a informetria e a webometria; subdisciplinas que apresentam semelhança, mas estabelecem a medição da difusão do conhecimento científico desde diferentes perspectivas. Um amplo panorama sobre o surgimento e evolução da bibliometria, com destaque para as leis desta disciplina, é oferecido por Lawani (1981, p. 1) e Urbizagástegui (2007, p. 10), quem expressam que, desde 1923, o termo "bibliometria" foi cunhado por Edward Wyndham Hulme, referindo-se a uma "análise estatística de uma bibliografia da anatomia comparativa", e destacam que Pritchard não é quem cunhou o termo bibliometria, como é comumente conhecido. Já sobre Pritchard (1969, p. 2), o que ele estabelece é que o termo bibliometria poderia ser usado explicitamente em todos os estudos que procuram quantificar os processos de comunicação escrita.

A respeito da cientometria, Vanti (2002, p. 153) afirma que ela surgiu na antiga URSS e na Europa Oriental. Originalmente, referia-se à aplicação de métodos quantitativos para o estudo da ciência e do progresso tecnológico. Já a partir da década de 1980, quando o Institute for Scientific Information (ISI) vendeu seu banco de dados para várias instituições, como uma ferramenta auxiliar para o desenvolvimento de políticas científicas, é que a cientometria torna-se área de interesse científico. $O$ termo Informetria foi inicialmente proposto por Otto Nacke, diretor do Institut für Informetrie, em Bielferd, Alemanha, em 1979, mas o aceite deste termo remonta-se a 1989 desde a Conferência Internacional de bibliometria, Cientometria e Informetria (BROOKES, 1990). A Informetria é o estudo dos aspectos quantitativos da informação em qualquer formato e em qualquer grupo social, não apenas de grupos científicos, bem como a comunicação falada informal (TAGUE-SUTCLIFFE, 1992, p. 1). A webometria é a aplicação de métodos informétricos para a World Wide Web (VANTI, 2002, p. 153).

A bibliometria pode ser dividida em fundamental e aplicada. A bibliometria fundamental é dedicada a descobrir os fatores causais subjacentes nos fenômenos bibliográficos; a aplicada ou prática é dividida em inferencial, descritiva, avaliativa, relacional. O objetivo da inferencial é a criação e o desenvolvimento de indicadores e descritores da literatura científica (URBIZAGÁSTEGUI, 2007, p. 16). A descritiva possibilita estabelecer hipóteses sobre a informação analisada, usando matrizes e 
análise de dados; a avaliativa destina-se a avaliar o impacto da produção acadêmica e compara as contribuições relativas de dois ou mais indivíduos ou grupos, a partir das citações; a bibliometria relacional tem como objetivo visualizar relacionamentos na estrutura cognitiva dos campos de investigação, o surgimento de novas frentes de pesquisa nos padrões de coautoria, entre outros (JACOBS, 2010).

Com esta breve introdução à ciência da informação, podemos estabelecer que os estudos neste domínio são mais do que uma pesquisa quantitativa ou estatística. No entanto, optamos por uma abordagem com ferramentas da bibliometria, de análise documental e de análise de conteúdo, para rever a produção acadêmica escrita, a qual está compilada em grandes repositórios, a respeito da delimitação conceitual das noções: "moradia adequada" e "moradia digna"; esclarecendo que a base teórica dos autores não foi explorada, pois o que queríamos revisar era a incidência nesse tema e os autores relevantes.

A análise documental, como uma técnica que visa representar o conteúdo de um texto em uma forma diferente do original, baseada na classificação e indexação temática, e cuja finalidade é facilitar consultas subsequentes (ANDRÉU, 2002), permitiu classificar os documentos de acordo com as seguintes categorias: repositório de produção acadêmica; título, revista, ano, palavras-chave ou assunto do artigo; palavras de busca nos repositórios; autor e a sua filiação; tipo de publicação; lugar geográfico de estudo (não aplicável para todos os documentos); idioma; relevância; tema de abordagem. A respeito destas duas últimas categorias, fizeram parte da análise do conteúdo dos documentos, como uma técnica de investigação que permite fazer inferências ou explicações que são aplicadas a um contexto (KRIPPENDORFF, 1990). A análise de tal quantidade de informação foi suportada no software Atlas.Ti para análise de dados qualitativos, cujas categorias de indexação e de análise dos textos foram as mencionadas.

No Quadro 4.1 expomos a quantidade de documentos por repositório de produção acadêmica e por expressões de busca. 


\begin{tabular}{|c|c|c|c|c|c|c|c|c|c|c|c|}
\hline \multicolumn{12}{|c|}{$\begin{array}{c}\text { Quantidade de documentos por repositório de produção acadêmica } \\
\text { e por expressões de busca }\end{array}$} \\
\hline \multirow[b]{2}{*}{$\begin{array}{l}\text { Expressões de busca no título, na } \\
\text { palavra-chave e no assunto dos } \\
\text { documentos; em Português, } \\
\text { Espanhol e Inglês }\end{array}$} & \multicolumn{10}{|c|}{ Repositórios de produção acadêmica } & \multirow[b]{2}{*}{$\begin{array}{l}\text { Período } \\
\text { dos textos } \\
\text { em anos }\end{array}$} \\
\hline & 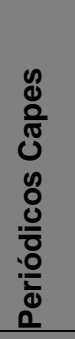 & 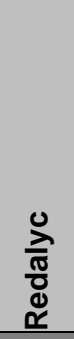 & $\frac{0}{\frac{0}{0}}$ & $\begin{array}{l}y \\
\frac{8}{0} \\
\frac{\pi}{0} \\
\frac{0}{0} \\
\frac{0}{0} \\
\frac{2}{5} \\
\frac{1}{5}\end{array}$ & 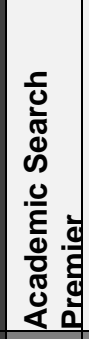 & 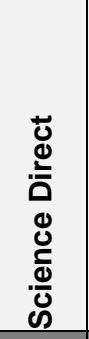 & 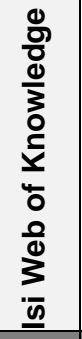 & 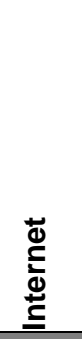 & $\stackrel{\substack{0 \\
\frac{2}{20}}}{-\frac{\pi}{>}}$ & 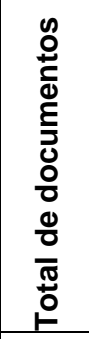 & \\
\hline Moradia/Habitação and Adequada & 1 & & & 10 & & & & & 6 & 17 & $2002-2011$ \\
\hline Moradia/Habitação and Digna & 2 & & & 9 & & & & & & 11 & $1997-2013$ \\
\hline Dignidade & 1 & 21 & 11 & 90 & & & & 1 & & 124 & $1990-2013$ \\
\hline Vivienda and Adecuada & 1 & 1 & 1 & 8 & & & & 4 & & 15 & 2003-2012 \\
\hline Vivienda and Digna & 9 & 9 & & 56 & & & & 6 & & 80 & 2003-2014 \\
\hline Vivienda and Dignidad & & 1 & & & & 1 & & 1 & & 3 & $2008-2011$ \\
\hline Dignidad & 1 & 93 & 30 & 40 & 2 & 1 & & 17 & & 184 & $1982-2014$ \\
\hline Adequate and Housing & 9 & & & 2 & 5 & & 1 & 2 & 1 & 20 & 1970-2011 \\
\hline Affordable and Housing & 107 & & & & & 27 & 29 & & 7 & 170 & 1974-2014 \\
\hline Decent and Home & 8 & & & & 1 & & & 0 & & 9 & 1978-2012 \\
\hline Decent and Housing & 11 & & & & & & & & & 11 & 1980-2011 \\
\hline Dignity and Housing & 4 & & & & & & & 6 & & 10 & 1992-2013 \\
\hline Dignity and Home & 5 & & & & 10 & 2 & 5 & & 4 & 26 & $1975-2013$ \\
\hline Dignity & 79 & 3 & 8 & 53 & 137 & 32 & 124 & 11 & & 447 & 1975-2013 \\
\hline Total documentos & 238 & 128 & 50 & 268 & 155 & 63 & 159 & 48 & 18 & 1127 & \\
\hline
\end{tabular}

Convenções

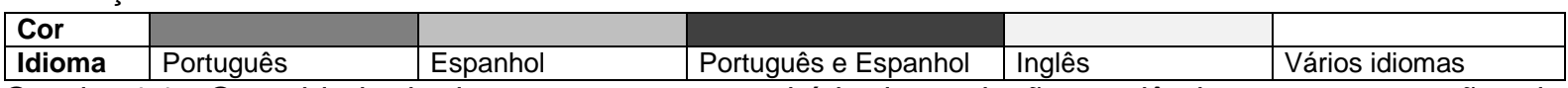
Quadro 4.1 - Quantidade de documentos por repositório de produção acadêmica e por expressões de busca, com corte para dezembro de 2014.

Fonte: Elaboração própria.

Obs.: A coluna "Scielo" refere-se ao repositório que abrange a Ibero-América, e inclui ao Scielo-Brasil.

A coluna "Universidades" corresponde à Universidade de São Paulo (USP), Brasil; e a universidades da Colômbia. As universidades da Colômbia revisadas foram: Eafit, Pontificia Universidad Javeriana, U. de Antioquia, U. de Medellín, U. del Magdalena, U. del Norte, U. del Rosario, U. de la Sabana, U. de la Salle, U. de los Andes, U. La Gran Colombia, U. Libre de Colombia, U. Luis Amigó, U. Nacional de Colombia, U. Pontificia Bolivariana.

A coluna "Vários" corresponde a repositórios de produção acadêmica com menos de vinte documentos, encontrados segundo as expressões de busca. Estes repositórios foram: ASCE Library, Biomed Central, Blackwell, BMJ, Cambridge Journals, IEEExplore, Journal Clinic Nursing, Metapress, Oxford Journal, Springer, Taylor \& Francis Group, Willey Online.

Repositórios consultados sem documentos relevantes: Collectionscanada.gc.ca, teses do Canadá. Dialnet, teses da Espanha e Portugal. Ethos.bl.uk e Teseo, teses da Europa. Netd.ac.za, teses da Sudáfrica. Scirus ETD, Project Muse, com artigos sobre direitos sociais como a moradia. Scopus, com textos pertinentes só com resumo, mas que se encontravam completos e disponibilizados para sua leitura em outros repositórios.

A análise da produção acadêmica sobre habitação, sob os instrumentos da bibliometria descritiva e da relacional, admitiu um primeiro exame da informação escrita e compilada em bancos de dados, a partir das palavras significativas do título, do resumo, e das palavras-chave dos documentos; assim como desde os descritores 
que forneciam os repositórios. Este primeiro passo nesta busca bibliográfica foi dirigido pelas expressões "moradia adequada" e "moradia digna"' e suas equivalentes em Espanhol e Inglês, contidas no título, palavra-chave e assunto dos documentos. Isso revelou que essas expressões são usadas alternadamente nos vários idiomas; além de que são adotadas outras noções semelhantes com abordagens diversas, dependendo do idioma e dos lugares geográficos prevalecentes dos repositórios. Livros e artigos que conse guissem ser lidos na íntegra on-line, ou porque sua consulta fosse possível, foi um critério de seleção. Observamos que se os termos de busca estavam incorporados no título, palavra-chave ou tópico do documento, o autor estava discutindo sobre o assunto, ao contrário de sua inclusão só no resumo ou no corpo, critério a partir do qual houve descarte de textos não relevantes. Descartamos ademais os textos que foram apenas resumo, comentários, palestras, jornal de revista, entrevistas transcritas, leis, regulamentos, processos jurídicos de estudos de caso. Nós optamos por adotar artigos publicados em revistas científicas, considerando que eles são submetidos a uma revisão crítica por pares acadêmicos. A revisão teve como corte temporário, para dezembro de 2014, com um total de 1.127 documentos.

Com apoio nos instrumentos referidos e nos critérios de seleção, nós estabelecemos a relevância do documento e os vários temas e campos de conhecimento que esse abordava; também surgiram diferenças dependendo do repositório de dados, do idioma do documento e do campo de conhecimento no qual o artigo se insere. Deste modo descobrimos vertentes sobre o tema da moradia, e, por conseguinte, a possibilidade de abordagens alternativas ao objeto de estudo desta pesquisa, não previstas com anterioridade.

\subsection{Vertentes, temas e debates na produção acadêmica sobre habitação}

Sobre os repositórios e o idioma, ISI Web of Knowledge e Science Direct privilegiam os textos em Inglês de instituições acadêmicas dos Estados Unidos e da Europa, com um mínimo de documentos com editoriais da Espanha e de Portugal. Academic Search Premier é mais amplo que os anteriores em termos de localização geográfica e língua, mas com grande parte dos documentos em Inglês. Repositórios da Ibero-América, como Redalyc e Scielo, com textos na sua maior parte em Espanhol, Português e, em menor medida, em Inglês e outros idiomas. Periódicos Capes do Brasil compila a produção acadêmica nacional e internacional, para uma boa porcentagem da documentação em Português, sem descartar a produção acadêmica em outras línguas, que também se localizam nos repositórios listados, nos quais há uma percentagem muito alta dos textos cujas expressões de pesquisa foram "affordable" e "dignity". 
Para o caso da Universidade de São Paulo, no Brasil, e das universidades da Colômbia, perto de uns $65 \%$ dos textos fazem referência à dignidade inerente ao ser humano; o restante discorre sobre a dignidade na bioética, a ética no campo profissional da saúde e no cuidado do paciente. Nos textos escritos em espanhol, gravados em repositórios que têm considerado o inglês como a língua predominante, e com títulos que contêm a expressão "vivienda adecuada", sua tradução para o inglês era "affordable housing"; para "vivienda digna" tornava-se "adequate housing".

Uma percentagem muito baixa de artigos discute a delimitação conceitual da moradia adequada e da moradia digna. Desde que esta revisão, com os termos de pesquisa em questão, forneceu um mínimo de textos relevantes, prestamos atenção às outras noções equivalentes expostas nas palavras-chave dos documentos, para encontrar: "decent home", "decent housing", "dignity home", "dignity housing", "dignity"; cujos artigos, nos quais se localizaram essas palavras-chave, estavam inseridos na área da saúde, da bioética e da ética no cuidado do paciente, e com autores preocupados com as condições de vida em espaços não adequados para pessoas com condições especiais de ordem física, mental ou de saúde. Para "dignity", foram encontradas duas posições de autores: alguns explicitaram que a dignidade não pode ser medida porque é inerente ao ser humano; bem como outros expuseram que a dignidade poderia ter uma dimensão prática. A palavra "home" aponta para estudos que visam rever as condições de vida; "housing" aborda a política habitacional para o acesso à moradia, desde o econômico.

Desde as diversas expressões de busca, contidas no Quadro 4.1, descobrimos abordagens predominantes desde as quais emergiram três vertentes, e no interior destas, alguns temas, a partir dos quais se move o debate sobre moradia: i) a política de habitação, ii) o direito à moradia, e iii) a moradia adequada para indivíduos com condições especiais de saúde física e mental.

\subsubsection{Política de habitação}

A política de habitação como vertente emergiu desde "Affordable housing", mas não encontramos nessa vertente, documentos relevantes que ofereceram informações para o propósito desta pesquisa. Com "Affordable Housing", 83\% dos textos examinaram políticas de habitação, em matéria de acesso econômico ao domicílio, com uma maior percentagem dos Estados Unidos; seguido pelo Reino Unido, Arábia Saudita, Botswana, Brasil, Canadá, Colômbia, Escócia, China, França, Havaí, Hong Kong, Irã, Nigéria, lêmen, Paquistão. 8\% concentraram-se no estudo de opções de alta eficiência de energia, sobre novos materiais para a habitação ou na discussão sobre Green Housing, em percentual maior para áreas residenciais dos 
Estados Unidos e com alguns textos lidando com países europeus. 9\% preocuparamse pela política de habitação a respeito das condições de vida nos albergues para pessoas em desvantagem, seja por suas condições econômicas ou porque elas têm problemas de saúde mental, álcool ou drogas, principalmente dos Estados Unidos.

"Decent Home" "Decent Housing" e "Adequate Housing" são expressões de pesquisa desde as quais se revistaram políticas de habitação não bem-sucedidas, em relação às condições de vida e à dificuldade de acesso econômico a programas de moradia, por parte da população de baixa renda, minoritária ou vulnerável, principalmente dos Estados Unidos e da Grã-Bretanha.

\subsubsection{Direito à moradia}

A palavra de busca "Vivienda Digna" abrange textos cuja discussão desenvolveu-se em um marco de direitos, seja porque acorreram à permeabilidade dos direitos invocando instrumentos jurídicos de direito internacional, porque revisaram instrumentos e ferramentas jurídicas pelos quais a violação ao direito à moradia poderia ser argumentada, ou porque buscaram desde o jurídico que esse direito fosse garantido. Os $45 \%$ discorreram sobre os instrumentos jurídicos existentes ou a natureza desse direito. Uns $24 \%$ sobre movimentos sociais na luta pelo teto, também em um marco de direitos. Os indicadores de habitação, os casos de estudo e os concursos para projetos de moradia foram revistos nos $28 \%$. Chama a atenção que vários artigos e livros da Colômbia, cujos títulos contêm essa expressão de busca - porquanto essa nação estipula na sua Constituição o direito à moradia digna-, não se referem a sua delimitação como direito, senão que foi abordada desde diversos tópicos desde os quais se concluem que o direito à moradia digna não foi atingido, tais como: controvertem a política de habitação desse país, apresentam casos de áreas residenciais ou de projetos de habitação não bem sucedidos, convocam a concursos para projetos de habitação digna.

A respeito de "Vivienda Adecuada", os $100 \%$ dos textos revisaram o direito à moradia para a Ibero-América, desde os instrumentos jurídicos internacionais expostos nestes textos. A busca por "vivienda digna o adecuada" torna visível uma quantidade considerável de documentos abordando o direito à moradia digna ou a adequada de países da América Latina de fala hispana. "Vivienda digna $\mathbf{y}$ adecuada" para os textos cujo lugar de análise é a Espanha e Portugal. Consideramos que essa diferença de um ou outro termo para a América Latina e a combinação dos dois termos para as duas nações, acima mencionadas, corresponde a que as Constituições desses estados da Europa estabeleceram a "Vivienda digna Y adecuada" como um direito, enquanto as duas qualificações não aparecem ao 
mesmo tempo como adjetivos nas Cartas Políticas da América Latina, ainda que, em todos esses países, a moradia é um direito.

Em muito poucos textos foram encontrados a expressão "Vivienda Dignidad", os quais abrangeram temas como o direito à moradia nas Constituições dos países da América Latina; a aplicabilidade desse direito na política habitacional colombiana; ou sobre morrer com dignidade no domicilio.

Para "Moradia/Habitação Digna", o número total de textos destinou-se à revisão do direito à habitação no Brasil desde os estudos de caso ou o parecer de especialistas na questão urbana, sobre o que deveria ser uma habitação digna. "Moradia/Habitação Adequada" discute contextos e situações ocorridas em diversos projetos e áreas residenciais do Brasil, pelas quais foi considerado que o direito à moradia não foi garantido. Com "Adequate Housing", os $45 \%$ discorreram sobre ferramentas jurídicas para que esse direito possa ser atingido. Os 30\% dos documentos delimitaram o direito a uma adequate housing, com três textos de Leckie (2006; 1992; 1989).

Assim, o direito à moradia nessa vertente foi abordado a partir de dois temas: i) desde um olhar crítico aos instrumentos jurídicos do direito internacional, permeados com o direito à habitação, e ii) desde pensar a provisão de moradia em sua eficiência funcional e, por sua vez, como um direito.

\subsubsection{Direito à moradia desde um olhar crítico aos instrumentos jurídicos de direito internacional, em permeabilidade com esse direito}

Os instrumentos jurídicos internacionais foram invocados em diversos textos para expor a permeabilidade entre eles quando for violado um direito. Leckie relata essa permeabilidade dos direitos como um estado em que os instrumentos jurídicos de direito internacional possuem um conjunto de elementos que os vinculam de maneira direta a outros direitos existentes, que, de modo holístico, incluiria, por exemplo, o vínculo do direito à moradia com outros, como o direito à privacidade, ao desenvolvimento, à saúde, às crianças, e que poderiam apoiar as demandas sobre 0 direito à habitação, ainda que muitos dos assuntos sobre o direito à habitação sejam muito gerais nos instrumentos internacionais (1992, p. 41).

Dos instrumentos jurídicos internacionais invocados nos documentos de acadêmicos, mostrando a permeabilidade com o direito à moradia, encontrou-se a Declaração Universal dos Direitos do Homem (DUDH) de 1948, o Pacto Internacional sobre Direitos Econômicos, Sociais e Culturais (PIDESC) e o Pacto Internacional sobre Direitos Civis e Políticos (PIDCP) de 1966, além do Pidesc de 1991 com a noção do 
"direito à moradia adequada", como o instrumento mais invocado e revisado pelos acadêmicos, bem como estipulado pelos especialistas como o mais pertinente a respeito desse direito.

Os documentos, cuja preocupação geográfica é a América Latina, revisaram ou invocaram, bem como os instrumentos anteriores, a Declaração Americana dos Direitos e Deveres do Homem (DADH) de 1948, que menciona o direito à habitação indiretamente sob vários tópicos como: o direito de fixar a residência e a se mobilizar com liberdade, a inviolabilidade do domicilio, a propriedade privada. Outro referencial foi o disposto no artigo 11 do Protocolo de San Salvador (1988), que protege o direito à moradia indiretamente quando estabelece que cada pessoa tem o direito de viver em um ambiente sadio e a ter serviços básicos. No entanto, os autores enfatizaram que, apenas, a partir de 1991, a moradia é considerada um direito delimitado, ainda que os elementos que o configurem precisem ser mais demarcados em seu conteúdo, para dar conteúdo ao direito à moradia.

Destacamos o livro de Galvis-Castro (2014), quem abordou metodologicamente o desenvolvimento jurisprudencial colombiano no campo do direito à moradia, evidenciando as demandas jurídicas mais paradigmáticas a este respeito e categorizando alguns comportamentos que violam esse direito. Também as publicações da Defensoría del Pueblo de Colombia $^{38}$ (2012; 2009; 2007), a respeito do conteúdo do direito à moradia digna e adequada. Essa instituição o que pretende é instaurar a noção de "vivienda digna y adecuada" para a Colômbia, de acordo e como consta na Constituição desse país, no artigo 51 -moradia digna para todos os seus cidadãos-, e segundo o PIDESC de 1991, que instituiu a noção de direito à moradia adequada. No entanto, na série de livros desse autor institucional, indiscriminadamente se utilizam várias expressões: "derecho a la vivienda, a la vivienda digna, a la vivienda digna y adecuada"; delimitando este direito apenas a partir dos sete elementos do PIDESC de 1991. No seu livro de 2009 compilou os instrumentos jurídicos internacionais que poderiam ser parte do que Leckie tem estabelecido como a permeabilidade dos direitos, e que esta instituição tem chamado de Bloque de Constitucionalidad, como

38 A Defensoría del Pueblo é a instituição do Estado colombiano responsável por impulsionar a efetivação dos direitos humanos dos habitantes da Colômbia e dos colombianos no exterior, no âmbito do Estado Social Democrático de Direito (DEFENSORÍA DEL PUEBLO, 2014). 
toda uma série de princípios, direitos e regras, que, embora não estão consagrados explicitamente na Constituição, fazem parte da ordem constitucional, pois a Carta Política estabelece dispositivos precisos para a sua incorporação nela [na ordem constitucional] (DEFENSORIA DEL PUEBLO, 2009, p. 20, tradução nossa). (C.C.C-067, 2003, tradução nossa).

\subsubsection{A moradia em sua eficiência funcional e por sua vez como um direito}

Craven $^{39}$ afirma que a moradia poderia ser observada sob dois aspectos. Primeiro, em sua eficácia funcional: como um elemento interdependente de outro bem; como um bem de valor econômico intrínseco, para uso próprio ou para o negócio; como um instrumento que traz benefícios; e segundo, desde uma social conception of housing. Para Craven, são exemplos do primeiro aspecto: a moradia considerada um elemento de um regime jurídico, que articula os direitos individuais e as obrigações com os recursos materiais como a propriedade; como uma mercadoria, com um significado prático, para delinear uma esfera de atividade privada protegida contra a interferência governamental; ou como um elemento de um bem mais geral ou de uma ação privada.

O segundo aspecto a respeito de uma compreensão social da moradia, conforme o autor, está mais associado com o valor intrínseco da habitação como abrigo, ou seja, que a moradia deveria conduzir à preservação da dignidade e da sobrevivência; um conceito mais identificado com a ideia de home que com a de house (CRAVEN, 2003, p. 48). Exemplos do primeiro aspecto são expostos por alguns autores, no entanto, a habitação como um conceito social é pouco desenvolvido 40 .

Ortiz ${ }^{41}$ assegura que existe uma compreensão da moradia e do habitat que os reduz a mercadorias, mas que também esses conceitos poderiam ser pensados em suas dimensões social, cultural e humana, para evidenciar as inter-relações que os potenciam como fatores de desenvolvimento, organização social, ordenamento territorial, preservação ambiental e fornecedores da economia social e solidária. Estabelece que poderiam ser várias as formas de pensar a habitação, das que vão derivar processos e padrões muito diferentes de produzi-la, distribuí-la e habitá-la,

\footnotetext{
39 Matthew Craven. Professor of International Law. University of London.

40 A WHO faz diferença entre house e home. House a define como a estrutura física usada para habitação humana. Home é a estrutura econômica, social e cultural estabelecida pelo grupo doméstico residente (WORLD HEALTH ORGANIZATION, 2010).

41 Enrique Ortiz, presidente da Habitat International Coalition (HIC). Instituição que inicia suas atividades por ocasião do Habitat I - 1976. É uma rede internacional independente e sem fins lucrativos. Age como grupo de pressão em defesa dos sem-teto, dos pobres e daqueles que vivem em condições inadequadas. Com status consultivo na ONU (HIC, 2014).
} 
com consequências na vida dos habitantes e na estrutura urbana. Ele expõe duas formas principais: i) a habitação como produto regulado pela oferta e pela demanda, na qual a moradia entende-se como um produto econômico escasso, que entra na competência por recursos limitados e por clientes também limitados em sua capacidade econômica para o seu acesso; e ii) a habitação como um direito; como bem social potencialmente abundante, que é a mais profusa e a que, segundo o autor, não se produz sob a ideia de bem escasso, mas sob formas que potenciam os recursos dos seus moradores. Na primeira abordagem, Ortiz abarca a moradia como um objeto; e na segunda, como o ato de habitar (2012).

Uma moradia que não deve ser percebida só como uma estrutura física que serve de abrigo, mas também o lugar onde uma pessoa, ou grupo, mora, é uma proposta de Leckie $^{42}$ (1992), quem ademais define uma adequate housing ${ }^{43}$ sob vários componentes: i) estrutura física; ii) lugar de construção de domicílio; iii) facilidades da infraestrutura; iv) custo acessível; v) localização que permita o acesso ao emprego e aos serviços urbanos; vi) segurança da posse para todo tipo de domínio e ocupação; vii) proteção contra formas de discriminação; viii) direito a participar de decisões sobre moradia e a selecionar a localização; ix) direito a ter moradias adequadas para moradores de rua e para outros casos especiais; $x$ ) proteção física, bem-estar e segurança; xi) a sensação de pertencer a uma família, comunidade e nação; xii) respeito, autoestima, aprovação, dignidade humana e autorrespeito; xiii) liberdade para permitir o desenvolvimento de talentos e capacidades (p. 4-6).

Os primeiros seis critérios e o critério $x$ do Leckie são mais de ordem material e referem-se a elementos de moradia adequada do Pidesc de 1991, motivo pelo qual esse autor enfatiza que a definição de uma adequate housing pode se basear nos elementos do Pidesc, no entanto, que não são suficientes para satisfazer uma ideia de home. Os elementos vii e viii relacionam-se com a participação e a capacidade do cidadão de compreender o que é uma moradia adequada e a exigi-la como um direito, critérios que se localizam mais no âmbito da cidadania. Os últimos três critérios de Leckie têm a ver com as necessidades não materiais como a dignidade, a participação, o respeito, o sentido de pertencimento, que o autor pouco desenvolve, mas que, ele enfatiza, devem ser incluídos no que abrange a moradia adequada; critérios que Ortiz e Craven vislumbram nas suas segundas vertentes. Seria a partir

\footnotetext{
${ }^{42}$ Scott Leckie. COHRE Founder, Former Executive Director of COHRE and Director of Displacement Solutions. Centre on Housing Rights and Evictions (COHRE), fundada em 1994, é agora a principal organização internacional dos direitos humanos que trabalha para a proteção do direito à moradia e a prevenção de despejos forçados ao redor do mundo. Trabalha em estreita colaboração com vários organismos e agências da ONU (COHRE, 2014).

43 Leckie (1992) desenvolve elementos sobre o que constitui a adequate housing porque esse é o termo utilizado em seu texto escrito em inglês. Alguns desses elementos também são desenvolvidos em (LECKIE, 2006).
} 
da avaliação prática que esses últimos três critérios de Leckie poderiam ser estabelecidos como variáveis de moradia, no entanto, não encontramos no argumento do autor, o como ou o porquê de implantá-las como variáveis de habitação.

\subsubsection{Moradia adequada para indivíduos com condições especiais de saúde física e mental}

A moradia adequada às necessidades particulares do morador, como uma linha de estudo de habitabilidade, emergiu quando nós nos deparamos com essas outras noções equivalentes encontradas na palavra-chave ou no assunto dos textos tais como "Dignity Housing" e "Dignity home". Desde a primeira expressão, 50\% dos documentos conferiram o grau de sucesso das políticas de habitação dos Estados Unidos. No entanto, desde "Dignity home", $24 \%$ dos seus textos discutem o morrer com dignidade nos próprios domicílios, e o cuidado paliativo. Desde essas duas expressões, os restantes textos examinaram as políticas de habitação dos Estados Unidos, Canadá e de vários países da Europa, acerca das condições de acesso e de habitabilidade dos abrigos para as pessoas que vivem nas ruas e para idosos; além do cuidado paliativo nas care home e nas nursing home para idosos. Também se investigou a necessidade de que os domicílios suportassem espaços e instalações especiais para atender as condições particulares dos pacientes com doenças mentais, crônicas, degenerativas ou terminais.

O encontro com artigos relativos ao acesso e à habitabilidade nos abrigos para as pessoas que vivem nas ruas, deficientes e enfermas, levou-nos a rever as palavraschave oferecidas pelos autores, para encontrar, na maioria dos textos, o termo "dignity". Essa descoberta deu origem a uma revisão mais completa nas bases de dados sob esta palavra e sua combinação com o espaço. Mesmo quando a referência mais proeminente à dignidade é a inerente ao ser humano, e assume-se uma compreensão implícita do que significa nos instrumentos do direito internacional; outros autores têm estado procurando outras formas de compreender à dignidade desde a jurisprudência, a bioética, a saúde pública, o cuidado paliativo; para debater problemas associados com a eutanásia, a clonagem, a morte com dignidade, a habitabilidade em espaços como casas de repouso, abrigos e casas para moradores de rua, deficientes, e para doentes com necessidades especiais; lugares, nos que por sua vez, já se assiste um homem doente e vulnerabilizado. A respeito dessa descoberta sobre outras acepções conferidas à dignidade, e que alguns desses autores as expõem nas suas conclusões, é que ela tem de ser vista em sua dimensão prática. 
Com "Dignity", em $8 \%$ dos textos, a dignidade foi vista a partir da jurisprudência, da soberania dos Estados e dos regimes políticos. 36\% examinaram a dignidade desde a filosofia, a teologia e a religião. $9 \%$ inspecionaram a relevância da noção de dignidade em direitos humanos; com um sexto dessa percentagem, que se refere à importância dos direitos dos deficientes, mulheres e homossexuais. O significado da dignidade em bioética com foco em questões como a clonagem, a eutanásia, a biotecnologia e os experimentos com seres humanos, a morte com dignidade, foi discutido nos $4 \%$. Outras formas de pensar a dignidade foram observadas em $43 \%$ dos documentos nos casos do acesso aos cuidados de saúde (health care), a partir da experiência do paciente, do cuidado paliativo, da saúde dos moradores de rua e das condições das care home.

Para a palavra "Dignidade", 30\% revisaram o conceito de dignidade inerente ao homem. $23 \%$ dos artigos examinaram, a partir da jurisprudência, da política e dos direitos humanos, a dignidade também com referência a esse inerente. 14\% conferiram-na à ética no cuidado ao paciente e à ética do profissional da área da saúde, enquanto $21 \%$ referiram-na ao cuidado paliativo e à questão sobre morrer com dignidade, o que mostrou outras formas de olhar a dignidade. Os outros documentos discutiram sobre como poderia se salvar a dignidade humana no trabalho ou na escola.

Por conseguinte, a palavra de busca "Dignidad" mostrou ser a mais difundida com a concepção que é esta inerente ao ser humano, com 20\%. 33\% dos artigos revisados apresentaram a dignidade desde a jurisprudência, a política e os direitos humanos, que também se referia à dignidade inerente ao homem. 32\% discorreram desde a bioética e a ética, o significado de dignidade em experimentos com seres humanos, em questões como a eutanásia, a eugenia, o aborto, a morte com dignidade. 0 cuidado paliativo e o cuidado ao paciente concerniram aos $10 \%$. Os últimos $6 \%$ mostraram vários textos relevantes: um documento de Elizalde (2002), o qual propôs variáveis para medir as condições de vida desde o indicador "linha de dignidade", a partir da renda do habitante, mas não controverteu sobre o conceito de dignidade. $O$ livro de Mantiila e Oñate (2013), com uma análise de como a Corte Constitucional da Colômbia tem usado como argumento o substantivo "dignidade" e o adjetivo "digno" em demandas jurídicas, tais como acciones de tutela, para que os direitos fossem garantidos.

Os textos consultados sobre outros olhares à dignidade foram, em sua maior parte, de autores que têm pertencido ou pertencem a instituições da área da saúde, da bioética e da psiquiatria, mas com diversas filiações institucionais de nacionalidades conhecidas por seu alto padrão de vida. Autores que proveram outras acepções à dignidade desde "Dignity" como Hoyos (2005); Jacobson (2012; 2009; 2009a); Killmister (2010); Nordenfelt (2004); Pyrrho, Cornelli e Garrafa (2009); Schroeder 
(2008); expuseram que a dignidade humana não fornece uma forma única para sua expressão e dimensão prática, pode ter a propriedade de ser observada no momento em que ocorrem as relações entre os indivíduos; ser entendida como uma experiência subjetiva, associada com o gozo das necessidades básicas, incluindo a moradia; ser perturbada em uma ação por outro sujeito e assim, com a faculdade de ser mensurada, promovida, violada. Muitos poucos autores foram mais além e expressaram que por conta de a dignidade abranger uma dimensão prática, poderia ser monitorada no espaço e na integridade do corpo e da psique do homem.

Essas outras acepções têm sido nomeadas como: a dignity of identity de Nordenfelt, que tem expressado que esta poderia ser refletida na integridade da mente e do corpo do indivíduo, e que pode ir e vir como resultado de interações, mas que é difícil de definir porque, em princípio, não depende de méritos subjetivos, mas sim de eventos externos, de atos de outras pessoas (2004, p. 71). Sulmasy com Inflorescent dignity, cujo foco de discussão para estabelecer este termo foi a eutanásia, declara que tal acepção depende de circunstâncias atuais do indivíduo e da compreensão explícita do valor intrínseco de cada ser humano (2012). Desde uma ideia de dignity as a subjective experience e de dignity as a perspective of other people, Mattson e Clark têm afirmado que poderia se verificar a dignidade de uma comunidade desde a medição do seu bem-estar, no marco dos seus relacionamentos e de suas normas sociais, concebendo, desse modo, a dignidade como uma experiência subjetiva com implicações práticas na política (2011).

Hoyos, a única autora de fala hispana que encontramos, abordou a dignidade como uma experiência, mas ela não desenvolve o da experiência. Ela tem exposto que a dimensão prática da dignidade refere-se a que reconhecer o outro é aceitar a pessoa como um fim em si mesmo, mas também é abster-se de fazer atos que interfiram com esse reconhecimento (2005). Killmister, desde a acepção aspirational sense on the other, desenvolve, na mesma direção que Hoyos, que o reconhecimento do outro como uma pessoa e o respeito pelo outro, são componentes complementares da dignidade humana (2010).

Dos autores que apresentam outra perspectiva para a dignidade, Jacobson ${ }^{44}$ (2012; 2009; 2009a) aproxima-se à discussão, desde um âmbito empírico, mas não de interpretação teórica. Ela desenvolve uma investigação empírica sobre o significado da dignidade na área da saúde, na qual identificou o que ela refere como a social dignity, como uma acepção na que a dignidade poderia ser monitorada. E concluiu que a violação à dignidade social poderia ocorrer na interação entre um sujeito

\footnotetext{
${ }^{44}$ Nora Jacobson, Centre for Addiction and Mental Health and Department of Psychiatry, Toronto,
} Canada. 
vulnerável por suas condições de saúde ou econômicas, com a busca de recursos na cidade, e quando a busca não fosse bem-sucedida, a integridade do homem poderia ficar comprometida.

No entanto, é necessário ter presente, e em concordância com Mattson e Clark, que as definições precisas da dignidade para uma comunidade, assim como as políticas destinadas a esta, variam segundo a cultura, o meio físico e as circunstâncias históricas. Além disso, levar em consideração, como esses autores enfatizaram, que só as próprias pessoas, nos lugares em que habitam, teriam respostas e ações a respeito da dignidade (2011, p. 316).

Sobre habitação e saúde, um artigo de Pasternak discute essa relação. Expõe que os indicadores, que definem moradia adequada no Brasil, colocam parâmetros mínimos restritos em relação à saúde e o bem-estar, e enfatiza que não são os desejáveis para um completo bem-estar no domicilio. Esta pesquisadora fornece quatro categorias de observação desta relação habitação-saúde: i) casa e doenças transmissíveis, que tem a ver com agua, esgoto, vetores de doenças, ventilação e isolação, adensamento ou pessoas por cômodo; ii) casa e necessidades fisiológicas, que é sobre o conforto térmico e acústico, espaço para o descanso, espaço para se movimentar e para brincadeiras, facilidade de manutenção; iii) casa e acidentes domésticos que versa sobre segurança física, proteção contra fogo e inundações, queimaduras, envenenamento de gás; iv) casa e saúde mental, com necessidades que envolvem privacidade, vida familiar, vida comunitária, facilidade de execução e manutenção das atividades domésticas, satisfação em concordância com padrões estéticos locais; mas afirma que existe a dificuldade na definição das variáveis intervenientes nessa última categoria $(2016)^{45}$. Para pôr em evidência que os riscos, em relação à saúde na moradia, são de extrema relevância (p. 51). As quatro categorias de observação desta pesquisadora referem-se aos Princípios da Moradia Saudável da OMS.

\footnotetext{
$45 \mathrm{O}$ artigo de Pasternak corresponde a 2016. Ainda que a revisão bibliográfica desenvolvida neste capítulo tenha como data de corte a dezembro de 2014, não era praticável deixar fora este artigo, pois expõe categorias e variáveis de observação na inter-relação morador-moradia, visando possíveis lesões ao homem pela habitação inadequada; e levando em consideração que quando o morador tem pré-existências de problemas de saúde física ou mental, é quando é mais vulnerável a essas variáveis expostas por essa autora. Esse artigo foi encontrado numa revisão, muito rápida, de artigos, em abril de 2016, encontrando-o sob a palavra de busca "moradia adequada" no resumo, mas não nas palavraschave. Essa autora nomeia a moradia como casa no sentido que dá a WHO à house, que se refere à estrutura física usada para habitação. Ver Nota de Rodapé $\mathrm{N}^{\circ} .40$.
} 


\subsection{A "moradia como direito" e a dignidade em sua dimensão prática. Síntese do âmbito acadêmico}

Vários dos autores acadêmicos apresentaram outra forma de pensar a moradia, diferente daquela de uma mercadoria. Eles, em sua maioria, têm pertencido ou pertencem ao âmbito público do político habitacional ou ao urbano, ao jurídico, à área da saúde trabalhando com população vulnerável. Desde o âmbito acadêmico, realizamos uma revisão de literatura, a qual está compilada em grandes repositórios de produção acadêmica do mundo, em documentos públicos disponíveis on-line; permitindo-nos estabelecer três vertentes desde as quais se move o debate sobre a habitação: i) política de habitação, ii) direito à moradia, e iii) moradia adequada para indivíduos com condições especiais físicas, mentais e de saúde.

Sobre a política de habitação, não encontrámos documentos pertinentes desde as palavras de busca. No que diz sobre o direito à moradia, a maioria dos documentos mostraram a necessidade de observar, avaliar ou discutir o problema de acesso econômico e da habitabilidade na moradia num marco de direitos. O que vimos com o relatado pelos autores listados no campo do direito é que, além de se aceitar que o contexto hoje da moradia é sua eficiência funcional, inserida em um sistema de mercado, busca-se, por sua vez, especificar itens associados a um conceito social, que se refere mais a uma ideia de home que de house ${ }^{46}$. Outro assunto é a alusão a instrumentos jurídicos de direito internacional tais como a Dudh de 1948, a Dadh de 1948, o Protocolo de San Salvador de 1988, e o Pidesc de 1966 e de 1991, mostrando desde essa permeabilidade dos direitos, uma ligação do direito à moradia com a dignidade.

As propostas de autores que revisaram a noção da moradia adequada, somente a partir da definição e dos elementos do Pidesc de 1991, aprofundaram em elementos mais de natureza material como a segurança da posse, a habitabilidade, a disponibilidade dos domicílios no que diz com a infraestrutura, com os serviços básicos e com os urbanos; a localização; com muito pouco desenvolvimento em elementos tais como a acessibilidade econômica, a economicidade e a adequação cultural, tanto desde o âmbito conceitual quanto de casos.

Em relação à terceira e última vertente - espaços adequados para indivíduos com condições particulares físicas, mentais e de saúde -, foi encontrada, em fases mais tardias da revisão dos autores acadêmicos, quando direcionamos atenção para pesquisar nos documentos expressões como: decent home", "decent housing", "dignity home", “dignity housing”, “dignity". Como resultado, o conteúdo dos

\footnotetext{
46 Ver Nota de Rodapé $N^{\circ} .40$.
} 
artigos expôs uma relação morador-moradia, com situações em que a integridade física ou mental de um indivíduo ou de um grupo homogêneo, pode ser lesada por espaços não adequados às necessidades particulares. A relação de "dignity" com "home" e com "housing" referiu-se aos espaços que pudessem suportar instalações espaciais para um sujeito já vulnerabilizado pela sua condição de saúde ou velhice; também sobre a capacidade da população vulnerável e geralmente sem teto, para o acesso ao alojamento temporário ou permanente. $O$ encontro com artigos relativos ao acesso e à habitabilidade nos abrigos para as pessoas que vivem nas ruas, deficientes e enfermas, levou-nos a rever as palavras-chave oferecidas pelos autores, para encontrar, na maioria dos textos, o termo "dignity", desde o qual encontramos um senso de dignidade que pode ser experiencial, mas perturbada nas interações entre indivíduos, quando o sujeito vai à busca de recursos no espaço.

Os espaços residenciais adequados para as condições particulares físicas, mentais ou de saúde do morador é uma questão intimamente ligada à área das políticas de acesso e de habitabilidade dos domicílios, bem como do direito a um lugar adequado para se viver, e é um elemento de discussão sobre a diferenciação entre a habitação adequada e a digna. No entanto, de acordo com esta revisão da literatura acadêmica, a preocupação por espaços residenciais adequados para as condições especiais de saúde, não foi abordada por estudos sobre a habitação ou o espaço, mas de áreas tais como a bioética, a ética em saúde, o cuidado paliativo relacionado com a habitabilidade em albergues para moradores de rua, idosos, alcoólatras, e mais outra população extremamente fragilizada, e em países como Estados Unidos, Canadá e Reino Unido, buscando não violar a dignidade desse homem já vulnerado por suas condições de saúde precária.

Chamou a nossa atenção que 0 aumento da produção acadêmica a respeito de diversas acepções à dignidade é dado após 2005, quando o relatório da Council of Europe's Bioethics Convention de 1997 e a Declaração Universal sobre Bioética e Direitos Humanos da UNESCO de 2005 começam a ser aplicados, pois a discussão de fundo nestes relatórios tem sido o papel da dignidade na bioética como conceito mensurável e viável para ser avaliado. Essa posição de dignidade, de interesse para esta pesquisa, examina quando a dignidade tem sido ferida em uma ação por outro indivíduo, em áreas como a eutanásia, a clonagem, a assistência na saúde (health care), a ética médica, a bioética; tentando resolver problemas associados com a morte com dignidade; com o atendimento e respeito ao paciente; com a habitabilidade em espaços de saúde tais como casas de descanso e abrigos para moradores de rua, para deficientes, portadores de necessidades especiais; lugares onde é atendido um habitante doente e debilitado.

As diversas acepções à dignidade, expostas neste Capítulo, permitiu-nos inferir que a dignidade poderia ser observada, e que a palavra "digna", como adjetivo e qualificação 
da moradia, oferece a perspectiva de que a dignidade pode ser lesada pelo espaço em que o homem mora, seja por sua condição pré-existente de vulnerabilidade e/ou pela precariedade do espaço, e, portanto, sua integridade física e mental.

As diversas vertentes e temas, que surgiram, visibilizaram o contexto no qual as políticas de habitação e de assentamentos estão se desenvolvendo, mas também nos permitiu vislumbrar outras possibilidades de olhar o espaço que o homem habita, desde a proteção da integridade do homem. 


\section{Capítulo 5}

\section{O DIREITO À MORADIA NO DIREITO COLOMBIANO}

\section{$5.1 \quad$ Introdução}

Um âmbito em que se busca dar conteúdo ao direito à moradia é a jurisprudência, motivo pelo qual neste Capítulo 5 e no Capítulo 6 é revisado o direito ä moradia em uma visão crítica, a partir do conteúdo de sentencias de tutela da Corte Constitucional da Colômbia, que tem argumentado a violação ao direito à moradia, como figura jurídica instaurada desde a Constituição de 1991 desse país.

Nesta tese serão examinados vários tópicos nas sentencias de tutela: a gênese, a evolução e a natureza do direito à moradia na Colômbia, até enxergar a noção atual do "direito à moradia digna" para esta nação - assuntos a serem revisados neste Capítulo 5 -; e a "demanda", no sentido do que o demandante percebe são os fatos, narrados nas sentencias, que violam o direito à moradia - questão a ser pesquisada no Capítulo 6 -. Outros temas que poderiam ser revisados desde sentencias de tutela desse Tribunal é a decisão adotada pelo juiz, ou o que acontece com o demandante ou o demandado depois da decisão, porém isso não é objetivo desta tese.

Este Capítulo está composto por três temas, examinados para se compreender o contexto do objeto de estudo - a moradia digna -, e que foram sendo descobertos um após o outro: i) a gênese e evolução do direito à moradia na Colômbia; ii) a natureza jurídica do direito à habitação nesse país; e iii) a noção do direito à moradia digna e sua permeabilidade com os instrumentos de direito internacional. No final, uma síntese sobre a evolução do direito à moradia para a Colômbia. Temas a serem indagados a partir das Constituições da Colômbia, e das Leyes de Indias, como regulação que regia o território e a ocupação das colônias da Espanha.

\subsection{O direito à moradia na jurisprudência da Colômbia. Abordagem metodológica}

Para o cumprimento dos direitos instaurados na Constituição vigente da Colômbia de 1991, foram criadas uma série de ações judiciais nessa Constituição, 
que nos países da América Latina são nomeadas como Recurso de Amparo. A Acción de Tutela para a proteção dos direitos fundamentais das pessoas; a Acción de Cumplimiento, que visa alcançar a real aplicação de leis e atos administrativos; a Acción Popular, vista como a proteção dos direitos e interesses coletivos; as Acciones de Grupo, a fim de garantir a compensação por danos causados a grupos compostos por mais de vinte pessoas; e Acciones de Pérdida de Investidura, que busca que a justiça remova o status de congressista para aquele representante que tenha incorrido em diferentes motivos, estabelecidos por lei (BOTERO e JARAMILLO, 2006, p. 42).

De interesse para esta pesquisa, temos a Acción de Tutela estabelecida no artigo 86 da Constituição da Colômbia de 1991 e suas disposições e procedimentos no Decreto 2591 (1991), que estabelece que é um instrumento ou ferramenta constitucional que autoriza qualquer pessoa natural ou jurídica, em qualquer tempo ou lugar, para ir perante um juiz da República, em busca de uma decisão que vai proteger um direito constitucional fundamental, ou um direito social em conexão com um direito fundamental, quando o demandante considera que, por qualquer motivo ou circunstância, tenha sido violado ou ameaçado um direito por um ato ou omissão de qualquer autoridade pública, ou por particulares. O demandante pode instaurar uma Acción de Tutela quando ele não tem outros meios de defesa jurídica para proteger um direito; ou quando, fosse para evitar um prejuízo irreparável, caso em que a tutela pode ser um mecanismo transitório. ${ }^{47}$

O demandante pode interpor a acción de tutela por escrito, ou verbalmente perante os respectivos escritórios jurisdicionais e deve se referir a determinado juiz. Mais a sentencia de tutela é a que contém por escrito a demanda interposta na Acción de Tutela e a decisão adotada pelo juiz; assim que, que deve conter com a máxima clareza: a ação ou omissão que motiva a tutela, os fatos que provocam a ameaça ou a violação de um direito, o nome e outras informações do demandante (quem instaura a demanda) e do demandado (agente vulnerador, autor da ameaça ou violação a um direito), a situação atual do demandante, o direito que o demandante considera

\footnotetext{
${ }^{47}$ Nesta tese vão ser nomeadas as expressões Acción de Tutela, Sentencia e Sentencia de Tutela pelas indicações em espanhol respectivamente: acción de tutela, sentencia, sentencia de tutela.

Seguem, portanto, alguns esclarecimentos a respeito da palavra "Tutela". Em primeiro lugar, em espanhol, em que ela tem várias acepções: "1. Autoridad que, en defecto de la paterna o materna, se confiere para cuidar de la persona y los bienes de aquel que, por minoría de edad o por otra causa, no tiene completa capacidad civil. 2. Cargo de tutor. 3. Dirección, amparo o defensa de una persona respecto de otra" (REAL ACADEMIA ESPAÑOLA, 2015). E, em segundo, Tutela, em português, que significa "autoridade legal sobre uma pessoa menor ou interdita" (PORTO EDITORA, 2003). Assim, verificam-se duas acepções distintas entre as duas línguas. Sempre que expressar nesta tese a palavra "tutela", será sob o significado em espanhol com a terceira definição. Esclarecimento feito na Introdução, Nota de Rodapé $\mathrm{N}^{\circ} .1$.
} 
ameaçado ou violado, outros dados que são usados pelo juiz para fundamentar sua decisão, e a decisão do juiz a respeito da violação a um direito ${ }^{48}$.

A pessoa natural ou jurídica, que, diretamente lesada pela violação ou ameaça a um direito fundamental, pode interpor uma acción de tutela no lugar onde o evento teve lugar, perante qualquer Juiz da República; igualmente pode interpor a ação um procurador legal; um representante, quando o detentor dos direitos não é capaz de promover sua própria defesa; um representante legal sobre uma pessoa menor ou interdita; o Defensor del Pueblo em nome de qualquer pessoa que solicitar essa representação ou que está em situação de desamparo, e funcionários municipais por delegação do Defensor del Pueblo49.

A Constituição da Colômbia também estabelece quatro Altas Cortes ou Tribunais de Alta $^{50}$. A Corte Constitucional da Colômbia é um dos quatro Tribunais de Alta desse país. Segundo o Artigo 241-19 da Constituição da Colômbia, esse Tribunal tem a função de revisar, na forma que a Lei determinar, as decisões judiciais que têm relação com a acción de tutela de os direitos constitucionais. O artigo 34 do Decreto 2591 (1991) dispõe que a Corte Constitucional deve definir três magistrados da sua Corte para conformar o grupo que revisa acciones de tutela, mas alterações na jurisprudência devem ser decididas pela Câmara Plena desse Tribunal. Desse modo, a Corte Constitucional da Colômbia se constitui um agente de relevância para esta pesquisa.

48 As sentencias da Corte Constitucional da Colômbia são de dois tipos: i) a sentencia de constitucionalidad numerada com "C" e emitida pela Sala Plena; ii) as decisões sobre a acción de tutela identificadas com "T", expedidas pela Sala de Revisão. Quando se decide unificar a doutrina constitucional em matéria de tutela, caso em que a Sala Plena vai conhecer o processo e vai emitir a decisão ou o fallo, é antecedida com "SU". Para sentencias de constitucionalidad (SC) e de unificación (SU), são nove Magistrados; para as sentencias de tutela são três os Magistrados que revisam acciones de tutela (OLANO, 2005).

Nesta tese, quase todas as sentencias analisadas foram de Tutela, baseada na definição que López faz das sentencias tipo SC e SU, as quais às vezes estabelecem apenas "normas-princípios" e não "normas-regras"; ou seja, que, as de tipo SC e SU não sempre elaboram sub-regras detalhadas porque não Ihes apresentam casos específicos que precisarem serem resolvidos (2006, p. 253, aspas do autor).

49 O Defensor del Pueblo e a instituição do Estado colombiano responsável por manter a eficácia dos direitos humanos dos habitantes do território nacional e dos colombianos no exterior, no âmbito do Estado Social de direito democrático, pluralista e participativo, através das seguintes ações integradas: promover, exercer e divulgar os direitos humanos, e evitar as suas violações; promover a observância do direito internacional humanitário; auxiliar, orientar e aconselhar aos cidadãos no exercício dos seus direitos, entre outras (DEFENSORÍA DEL PUEBLO, 2016).

${ }^{50}$ As quatro Altas Cortes ou Tribunais de Alta da Colômbia são: a Corte Constitucional como cabeça da jurisdição constitucional; a Corte Suprema de Justicia que é o mais alto tribunal da jurisdição ordinária; o Consejo de Estado que é o Supremo Tribunal no que respeita ao conjunto normativo, visando o regulamento de atividades da administração pública; e o Consejo Superior de la Judicatura, que tem duas salas: i) Câmara de Administrativo, que é responsável pela administração da divisão Judicial, e ii) Câmara de Jurisdição Disciplinar, encarregada do julgamento das falhas cometidas pelos agentes judiciais e pelos advogados (BOTERO e JARAMILLO, 2006, p. 42). 
Botero e Jaramillo afirmam que a Constituição é uma verdadeira norma jurídica, que deve ser respeitada e garantida pelas autoridades públicas, pois sua interpretação é feita por um Tribunal de Alta como a Corte Constitucional. Sobre a acción de tutela, o seu uso na Colômbia tem gerado uma revolução jurídica, pois através dela, todas as áreas da vida social e política vão sendo constitucionalizadas, e que não há quase nenhuma questão em termos de convívio social que não tenha solicitado a intervenção judicial por tutela (2006, p. 46, 65, 43).

Para o objetivo deste Capítulo de vislumbrar a gênese e a evolução da noção do direito à moradia na Colômbia, revisamos no âmbito da jurisprudência, as seguintes fontes: i) as Leyes de Indias e as Constituições da Colômbia para desvendar a gênese e evolução da noção em questão, como documentos que expõem o direito à habitação e mais outros direitos análogos; e ii) as sentencias de tutela, das quais as primeiras datam de 1992, até as de 2014, que expõem o descumprimento ao direito à habitação, e desde as quais indagou-se neste Capítulo pela evolução da natureza jurídica do direito à moradia digna e pela noção do direito à moradia digna para a Colômbia.

\subsection{Gênese e evolução da noção do direito à moradia na Colômbia}

\subsubsection{Do direito do colono a explorar o solo conquistado, ao direito do cidadão à moradia digna}

A Colômbia, como território descoberto pelos espanhóis, foi regida na época da colônia pelas Leyes de Indias de 1680. É uma legislação promulgada pelos Reis da Espanha, considerada um compêndio, construído no reinado de Carlos II, pelas seguintes leis: a) as Leyes de Burgos de 1512, as quais refletiam as possibilidades infinitas de riqueza que a coroa da Espanha vislumbrava nas Índias; b) as Leyes Nuevas de Indias de 1542, que regulava os termos de assentamento dos colonos espanhóis, e removia muitos dos seus privilégios sobre as terras das Índias e sobre os indígenas, estes últimos empregados como escravos, lei que em essência, gerou mais benefícios para os indígenas, e era automaticamente um prejuízo para o colono; c) as Ordenanças de Alfaro de 1612, que procurava melhor tratamento para o indígena, a supressão do seu trabalho escravo, a proibição da sua compra-venda, o pagamento pelo seu trabalho, a regulação de povoações de indígenas, entre outros (BERNAT, 2003).

Nas Leyes de Indias de Don Carlos, (1680), no seu Livro IV, Título 7-De la Poblacion de las Ciudades-Ley vij, dispõe-se que o território seja dividido da seguinte forma: território suficiente para os povoadores - os quais não estão inclusos os indígenas -, proporcionando ou uso da terra para pastagens e agricultura. $O$ restante será dividido em quatro partes: uma para o colono, que vai fundar, construir e povoar uma vila sob 
uma Capitulación ou contrato com a coroa da Espanha como soberana de todas as terras das Índias; e as três restantes em repartição igualitária para os povoadores, os quais não estavam incluídos os indígenas. Para a construção da vila, as Leyes de Indias ditam diretrizes para uma boa localização segundo o clima, a água, a terra fértil; regulam o tamanho das vilas, das quadras, das ruas, os usos da praça principal; fornecem critérios para a localização de praças pequenas, mercados, igrejas, mosteiros, entre outros usos; zoneamento para os ofícios, em particular para os que produzem odor e barulho; parâmetros gerais para a disposição das habitações segundo localização do sol, dos ventos e a sua conformação interior. Os critérios referidos foram os passos primórdios no território colombiano no que diz respeito a condições de habitabilidade na vila e no domicilio, e quem tinha direito à construção das vilas, à sua ocupação e ao usufruto do território.

A Colômbia tem passado por várias ordens: por Real Audiencia ${ }^{51}$ entre 1549 e 1718, quando o conquistador espanhol Gonzalo Jimenez de Quesada chamou-lhe de La Nueva Granada; Virreinato de 1719 até 1724; de 1724 a 1740 com um presidente; voltou para Virreinato até 1810, o qual foi suprimido pelos movimentos separatistas e de independência. Durante a colonização espanhola no século XVI, a população concentrou-se em algumas cidades estáveis: Santafé (Antioquia), Tunja, Pamplona, Popayán, Pasto e Cartagena, as quais depois fariam cada uma as primeiras constituições como território federal. Na última década do século XVIII, La Nueva Granada (Colômbia) sofreu repressão militar ordenada pelo Vice-rei Antonio Amar y Borbón, devido a acontecimentos de grande transcendência na história da Colômbia: a) a tradução dos Direitos do Homem de 1789 por parte de Antonio Nariño em 1793 e a sua difusão na imprensa, - o que o levou a julgamento e a prisão -; b) a Expedición Botánica52; entre outras ações. Eventos que, segundo os especialistas, propiciaram a Declaração de Independência da Colômbia da Coroa da Espanha no ano de1810.

Entre 1810 e 1815, segundo Melo, a Colômbia teve a maior produção de textos constitucionais da América Latina; assim que, no período referido, os dirigentes escreveram regras constitucionais para os diferentes estados que configuravam a Colômbia como território federal. A Constitución del Estado Libre e Independiente del Socorro de 1810 foi a primeira carta republicana, e fundamentou-se em "derechos naturales e imprescriptibles de la libertad, igualdad, seguridad y propiedad" (COLOMBIA. CONSTITUCIÓN DEL SOCORRO [1810], 2015). Direitos que também

\footnotetext{
${ }^{51}$ A Real Audiencia foi o mais alto tribunal de recurso nas Índias, o qual tinha jurisdição civil e criminal (ROSATI, 1996).

52 A Expedición Botánica, em 1783, foi promovida pelo Médico espanhol José Celestino Mutis. Foi a empresa científica máxima do período colonial; funcionou na forma de um instituto científico que era responsável pelo estudo dos recursos naturais e sua exploração. O projeto contribuiu para a educação e a formação científica de muitos jovens que foram chamados para perpetuar essas disciplinas no meio colombiano (DIAZ, 2009).
} 
estão garantidos em todas as subsequentes constituições da Colômbia. Desse modo, liberdade nas primeiras constituições foi definida como o poder de escolha sob a premissa de que não faça aos outros o que você não quer que seja feito a você. Igualdade, como a existência de uma lei igual para todos. O direito à segurança é determinado como a proteção à conservação da pessoa, aos direitos e às propriedades dos cidadãos. Esta Constituição do Socorro de 1810 é, segundo Alarcón-Bernal (2013), a precursora dos direitos dos povos indígenas, dos direitos sociais e adicionamos que do direito de propriedade ${ }^{53}$. A definição de propriedade se encontra na Constitución de Cundinamarca de 1811, na qual também se conforma 0 que poderia ter sido a primeira Asamblea Nacional Constituyente e o Congresso ${ }^{54}$. A propriedade delimita-se nas primeiras Cartas Políticas como

\begin{abstract}
la facultad que tiene el ciudadano de gozar y disponer libremente de sus bienes y rentas, y del fruto de su ingenio, trabajo e industria. [...]. Ninguno puede ser privado de la menor porción de sus bienes sin su consentimiento, sino en el caso de que la necesidad pública, legítimamente acreditada, así lo exija; pero aun entonces, es bajo la implícita condición de una justa y precisa indemnización (COLOMBIA. CONSTITUCIÓN DE CUNDINAMARCA [1811], 2015, Título XII. Art. 9, 10 ).
\end{abstract}

Na Acta de Federación de las Provincias Unidas de 1811 (2015), na qual o governo seria popular e representativo ${ }^{55}$, declararam-se constituições locais de tipo federalista, tentando se livrar do governo de Cundinamarca. Logo, Na Constitución de Tunja de 1811 (2015), nasce o derecho de petición, desde o qual qualquer cidadão poderia solicitar, legal e pacificamente, o reparo dos agravios (vulnerações) que fossem feitos a sua pessoa e o transtorno sofrido; figura com certa similaridade com a acción de tutela.

\footnotetext{
53 Artigo 14 sobre o direito à propriedade dos indígenas: "[...] [declaramos] a los indios de nuestra Provincia LIBRES DEL TRIBUTO que hasta ahora han pagado [sin libertad] y mandando que las tierras llamadas resguardos se les distribuyan por iguales partes para que las posean con propiedad y puedan trasmitirlas por derecho de sucesión; pero que no puedan enajenarlas por venta o donación hasta que hayan pasado veinticinco años contados desde el día en que cada uno se encargue de la posesión de la tierra que le corresponda" (COLOMBIA. CONSTITUCIÓN DEL SOCORRO [1810], 2015, palavras em caixa alta do autor).

${ }^{54}$ A Asamblea Nacional Constituyente é uma instituição concebida para a criação ou modificação de uma Constituição. Em dezembro de 1990, os colombianos votaram para a formação de uma Assembleia deste tipo, composta por 70 integrantes, responsáveis de modificar a Constituição de 1886, para deixar como resultado a atual Constituição de 1991.

O Congresso da Colômbia é o mais alto órgão representativo do poder legislativo, sendo o que reforma a Constituição, faz leis e exerce o controle político sobre o governo e a administração.

55 Províncias que faziam parte desta Constituição: Cartagena, Mariquita, Casanare, Pamplona e Popayán (MELO, 2015).
} 
A Constitución de Cúcuta ou Constitución de La Gran Colombia (1821) cria a República de "La Gran Colombia" pela unificação de La Nueva Granada (Colômbia e Panamá) e da Venezuela, o Equador se une a esta nação com posterioridade; o governo da Colômbia foi declarado popular e representativo, promulga a libertação progressiva da escravidão, e acaba com a inquisição. Depois, vêm as Constituições de 1830, 1833 e 1853. Na Constitución de los Estados Unidos de Colombia (1863) e de (1886), o preâmbulo invoca ao povo como fonte de autoridade, o que continua até a Constituição vigente de 1991, a qual institui a democracia participativa, substituindo a democracia representativa que vinha das anteriores Cartas Políticas.

Os textos constitucionais da Colômbia até 1812 e de outros Virreinatos da América fundamentaram-se, segundo os peritos, na Declaração dos Direitos da Virginia de 1776 dos Estados Unidos, considerada pelos especialistas como a primeira declaração dos direitos do homem; também na Declaração dos Direitos do Homem de 1789 e na Constituição da França de 1795 (ALARCÓN-BERNAL, 2013); (MELO, 2015).

Sobre a Espanha, o colapso de sua monarquia, entrincheirada durante três séculos, acontece em 1808. Foi instaurada nesse ano a Carta de Bayona, emitida por José Bonaparte, para governar a Espanha e as Índias; depois acontece a monarquia hereditária, que se reflete na Constitución de La Monarquía Española ou mais conhecida como Constitución de Cádiz, emitida no ano de 1812. Esta última, como única Constituição vigente em algumas províncias de La Nueva Granada (Colômbia como território federal), leais à coroa espanhola (ALARCÓN-BERNAL, 2013), ainda que para essa data tenha acontecido a independência da Colômbia da Coroa da Espanha. De 1812 até 1815, as Constituições da Colômbia inspiraram-se na Constituição de Cadiz de 1812, mas ainda com influência das Constituições dos Estados Unidos e da França (MELO, 2015), referidas no parágrafo anterior. Um assunto análogo à moradia é a inviolabilidade do domicilio, existente em todas as Cartas Políticas da Colômbia, e que se estipula como direito desde a Carta de Bayona de 1808 no seu artigo CXXVI.

La casa de todo habitante en el territorio de España y de Indias es un asilo inviolable; no se podra entrar en ella sino de dia, y para un objeto especial determinado por una ley, o por una orden que dimane dela autoridad publica (ESPAÑA. CARTA DE BAYONA [1812], 1812).

A Constituição Política vigente da Colômbia de 1991 em vários de seus artigos refere-se à habitação e ao digno. Desde seu artigo 51, os colombianos têm direito à moradia digna. A garantia do respeito à propriedade e o reconhecimento da propriedade tanto individual como coletiva é estabelecida no Artigo 58 e 64 . O direito à liberdade está refletido no direito à livre circulação e a eleger o lugar de residência 
(Art.24). O respeito para com o âmbito interno da moradia estipula-se no domicílio inviolável (Art.28), o direito à intimidade, à privacidade e ao bom nome (Art.15 e 42). Assim como o direito à vida pode ser observado na integridade física e moral (Art.11, 12). A dignidade como um objeto protegido está contida na Constituição da Colômbia:

Colombia es un Estado social de derecho, organizado en forma de República unitaria, [...] fundada en el respeto de la dignidad humana (Art. 1) [...]. Toda persona tiene derecho a un trabajo en condiciones dignas y justas (Art. 25). [...]. La honra, la dignidad y la intimidad de la familia son inviolables (Art. 42) (COLOMBIA. CONSTITUCIÓN [1991], 1991)

A Constituição vigente colombiana limitou o direito só à moradia digna, enquanto que a espanhola, é o direito à moradia digna e adequada. As Constituições vigentes dos dois países exibem similitude no conteúdo dos direitos referidos sobre habitação e o digno. Especialistas expõem que a Carta Política da Colômbia de 1991 apoiou-se da Carta vigente da Espanha de 1978. No Apêndice D apresentamos uma comparação entre essas duas Constituições vigentes da Colômbia e da Espanha, a respeito dos direitos associados mais abertamente com o da moradia.

\subsubsection{O direito à moradia digna nas Sentencias de Tutela entre 1992 e 2014}

A análise de sentencias da Corte Constitucional da Colômbia forneceu informação sobre as diversas etapas e evolução da natureza jurídica do direito à moradia e sobre a definição deste direito. A primeira etapa que nega que esse direito possa ser fundamental; a segunda, na qual é aceito que, em certos casos, pode surgir conexão entre os direitos sociais e os direitos fundamentais, quando as autoridades públicas têm exercido omissões nas suas funções (GALVIS-CASTRO, 2014). Numa fase tardia, que prevalece em grande parte das sentencias de 2014, que é quando a proteção da moradia digna como direito fundamental é feita diretamente, ou seja, sem necessidade de argumentar a conexão com outros direitos fundamentais, mas admitindo a ação constitucional, em cumprimento dos requisitos gerais para quaisquer outros direitos fundamentais (C.C. T-099, 2014). ${ }^{56}$

\footnotetext{
56 Os direitos econômicos, sociais e culturais, mais conhecidos como os direitos sociais ou de segunda geração, estão estabelecidos no Pacto Internacional de Direitos Econômicos, Sociais e Culturais (PIDESC) de 1966, no seu Artigo 11: "[...] reconocen el derecho de toda persona a un nivel de vida adecuado para sí y su familia, incluso alimentación, vestido y vivienda [...]" (ASAMBLEA GENERAL, 1966).

Pisarello expressa que os direitos sociais, como um histórico teórico, são nomeados como direitos que precisam de uma intervenção ativa por parte do poder público, condicionados pelo economicamente possível; os direitos fundamentais caracterizam-se por proteger interesses que podem ser universais,
} 
$\mathrm{O}$ argumento da Corte a respeito da primeira etapa que nega que o direito à moradia, como um direito social, possa ser considerado fundamental, é que o reconhecimento e efetivação dos direitos sociais implica a outorga de recursos, geralmente de uma fonte de baixo orçamento; outorga que deve ser fornecida por meio da definição de políticas públicas, com a intervenção de várias autoridades para definir os critérios de distribuição, bem como os requerimentos e procedimentos que devem cumprir os eventuais beneficiários (C.C. T-099, 2014). Deste modo, as primeiras sentencias da Corte Constitucional em 1992 apontaram o direito à moradia como de natureza prestacional e de desenvolvimento progressivo, por não ser possível garantir sua proteção imediata (C.C. T-585, 2008). As sentencias de 1992 não estabelecem uma noção do direito à moradia digna. Em 1993 fornece-se uma noção a qual:

implica el reconocimiento de la dignidad humana, lo cual se traduce en un conjunto de condiciones materiales y espirituales de existencia del ser humano que permita vivir con cierta calidad, con el fin de permitir un espacio idóneo para el libre desarrollo de la personalidad. [...], y éste es de aquellos derechos que se predican solamente de la persona humana. [Es decir], el techo garantiza la protección de la salud y de la comodidad, que son dimensiones humanas por naturaleza [...] debido a que ésta [la persona humana] goza de la dignidad humana, elemento indispensable para tener el derecho a la vivienda digna (C.C. T382, 1993).

Depois de 1995, nas sentencias é mostrada em algumas ocasiões, uma ligação inseparável entre os direitos sociais com os fundamentais, desde que o prejuízo de tal situação descrita nas sentencias, possa ter como consequência a ameaça ou violação dos direitos fundamentais do reclamante tais como a vida, a integridade física, a igualdade, o devido processo legal, entre outros ${ }^{57}$, ou uma lesão do mínimo vital ${ }^{58}$, especialmente de pessoas em uma situação de vulnerabilidade.

De 1996 a 1998, encontramos um mínimo de sentencias que invocam o direito à moradia digna. Para as sentencias de 1998 a 2003, nas quais se discute principalmente o recálculo dos empréstimos imobiliários e as execuções hipotecárias, devido à bolha imobiliária, que ocorreu no final da década de 1990 na Colômbia, o direito à moradia volta a ser considerado de natureza prestacional, pois, como é

e que por seu caráter essencial, consideram-se relativamente indisponiveis para o poder público, privado ou para o mercado $(2003$, p. 26,28$)$.

${ }^{57}$ A respeito do referido, ver as sentencias: (C.C. T-894, 2005); (C.C. T-791, 2004); (C.C. T-363, 2004); (C.C. T-626, 2000); (C.C. T-190, 1999); (C.C. T-617, 1995).

58 O mínimo vital é entendido como a satisfação das condições mínimas que cada pessoa necessita para lidar com a vida em condições de dignidade humana (C.C. T-888, 2013). 
expressado na sentencia C-383 (1999): sua efetivação é estreitamente ligada a condições econômicas. Posto isso, continua afirmando a sentencia, que o papel do Estado é propiciar uma gestão eficiente que permita a realização do objetivo citado no Artigo Constitucional 51 no qual todos os colombianos têm direito à moradia digna. A respeito dessa argumentação, o que observamos foi que as sentencias desse período discutem temas associados à perda de domicílios pela bolha imobiliária, desde o olhar e os interesses da banca, e não desde o morador que perde sua habitação; elas não arriscam qualquer noção sobre a moradia digna; nas sentencias assume-se que o Estado não tem responsabilidade nessa situação, e a moradia compreende-se como um direito econômico.

A sentencia T-958 (2001), que discute conceder um subsídio a uma família que perdeu seu domicilio em um terremoto, oferece uma noção de moradia digna como um direito, mais próxima à promovida pelas sentencias de tutela de 2014. As várias ideias que compõem esta noção constituem precedente e serão aplicadas nas sentencias subsequentes.

El derecho a la vivienda digna, debe observarse, no se reduce a
un derecho a ser propietario de la vivienda en la que se habita.
Ello constituye una de las opciones, claramente vinculado a los
planes de financiación a largo plazo. Por el contrario, la vivienda
digna se proyecta sobre la necesidad humana de disponer de un
sitio de vivienda, sea propio o ajeno, que reviste las
características para poder realizar de manera digna el proyecto
de vida. [...] este derecho no se limita a la promoción de la
propiedad de la vivienda, sino que incluye el derecho a tener un
lugar digno donde vivir, sin que la propiedad importe el dominio
sobre el inmueble (C.C. T-958, 2001).

A Corte aceita a fundamentalidade do direito à moradia digna a partir da sentencia C-936 (2003); seu argumento baseia-se no artigo 11 do Pidesc de 1991, e, para futuras sentencias, neste e em outros instrumentos de direito internacional. Um exemplo disso é a sentencia T-1165 (2001) que é sobre o caso de um portador de HIV, a quem, por sua doença, Ihe é negada a compra da apólice de seguro de vida, como requerimento obrigatório quando se acessa a um crédito hipotecário. Nesta situação, o direito à moradia é considerado fundamental pela relação do fato com o direito à vida em condições dignas; mas para que isso seja possível, continua mostrando a sentencia, é necessário analisar as circunstâncias em torno do caso concreto com cuidado especial, porque só assim a Corte pode determinar se a necessidade de habitação carrega consigo os elementos que envolvem a dignidade ou a vida de quem busca a ajuda do Tribunal colombiano. Esta sentencia invoca o direito à moradia em conexão com o direito à vida, pois a vida está em perigo. A Corte define que a vida: 
não é um conceito limitado à ideia restritiva de perigo de morte, o que possibilitaria solicitar o amparo da tutela no caso em que o indivíduo esteja pronto a fenecer ou de perder uma função orgânica de forma definitiva. Mas isso é reforçado como um conceito mais amplo que a simples e limitada capacidade de existir ou não existir, estendendo-se para também garantir uma existência e condições dignas. O que se pretende é respeitar a situação 'existencial da vida humana em condições de plena dignidade', desde que 'para o homem não é só uma vida simples, mas um estilo de vida saudável', sempre que possível (C.C. T815, 2002, tradução nossa).

A posição anterior da conexão do direito à moradia como direito social, com os direitos fundamentais como a vida, é delimitada na T-045 (2009), desde parâmetros que devem intervir e serem analisados em casos concretos, para reivindicar a proteção do direito à moradia, tais como, i) a iminência do perigo deve surgir, e de tal magnitude que ponha em risco a vida, a saúde, a integridade física ou a dignidade da pessoa ou do grupo familiar; II) deve verificar a existência de sujeitos de proteção especial de risco; III) deve ser provado o dano ao mínimo vital e; iv) deve ser observado o detrimento à dignidade humana, expresso em degradantes situações que magoam o direito à vida e à saúde. $\mathrm{O}$ direito à moradia digna como fundamental é reconhecido, porfim, nas sentencias T-029 (2012), C-299 (2011) e T-585 (2008), e nas sentencias ulteriores, desde que esses critérios estejam presentes nos fatos descritos nas sentencias.

Sobre as situações específicas da Colômbia, tais como o deslocamento forçado devido ao conflito armado interno, considera-se que existem obrigações que as autoridades devem garantir relativas ao direito à moradia para a população deslocada, oferecendo, assim, uma noção de moradia digna para esta situação e este tipo de população na forma de critérios de intervenção, e que ademais, fundamenta invocando instrumentos de direito internacional tais como os Princípios Pinheiro para deslocamento forçado de 2005, e a Observação $N^{\circ} 7$ do Pidesc de 1997 sobre deslocamentos forçados 59 :

\footnotetext{
59 "Deslocamento forçado" refere-se a desplazamiento forzado em espanhol. É considerado um indivíduo deslocado em forma forçada (desplazado em espanhol) como "toda pessoa que tem sido forçada a migrar dentro do território nacional, abandonar a sua cidade de residência ou sua atividade econômica habitual, porque a sua vida, a sua integridade física, a sua segurança ou a sua liberdade foram violados ou estão diretamente ameaçadas, por ocasião de qualquer uma das seguintes situações: conflito interno armado, agitação e tensões internas, violência generalizada, violações em massa dos Direitos Humanos, violações do Direito Internacional Humanitário ou outras circunstâncias decorrentes de situações anteriores que possam alterar ou perturbar a ordem pública drasticamente" (EL CONGRESO DE COLOMBIA, 1997, tradução nossa). A Colômbia está entre os dez países com o maior número de pessoas deslocadas internas por causa de conflito armado. 6.044 .200 pessoas, $12 \%$ do total da população até 2014 . Mais de $63 \%$ dos deslocados na Colômbia vivem abaixo da linha da
} 
(i) Reubicar a las personas desplazadas que, debido al desplazamiento, se han visto obligadas a asentarse en terrenos de alto riesgo; (ii) brindar a estas personas soluciones de vivienda de carácter temporal y, posteriormente, facilitarles el acceso a otras de carácter permanente. En este sentido, la Corporación ha precisado que no basta con ofrecer soluciones de vivienda a largo plazo si mientras tanto no se provee a los desplazados alojamiento temporal en condiciones dignas; (iii) proporcionar asesoría a las personas desplazadas sobre los procedimientos que deben seguir para acceder a los programas; (iv) en el diseño de los planes y programas de vivienda, tomar en consideración las especiales necesidades de la población desplazada y de los subgrupos que existen al interior de ésta -personas de la tercera edad, madres cabeza de familia, niños, personas discapacitadas, etc.-; y (v) eliminar las barreras que impiden el acceso de las personas desplazadas a los programas de asistencia social del Estado, entre otras (C.C. T-581, 2010); (C.C. T-064, 2009); (C.C. T-216A, 2008).

\subsubsection{O Direito à Moradia Digna nas Sentencias de Tutela e sua permeabilidade com os instrumentos jurídicos de direito internacional}

A revisão da evolução do direito à moradia na jurisprudência da Colômbia permitiu que deparássemos com várias frases comuns encontradas nas sentencias de tutela, que aludiam à noção desse direito, tornando possível reconstruir a seguinte delimitação do direito à moradia digna, esclarecendo que a totalidade desta noção não está em qualquer sentencia, mas apenas por frases conforme o caso em discussão nas sentencias ${ }^{60}$ :

Es más que tener un tejado por encima de la cabeza ${ }^{61}$. Es un lugar propio o ajeno ${ }^{62}$. Donde poder pasar las noches ${ }^{63}$, resguardarse de

pobreza, e 33\% vivem na pobreza extrema (INTERNAL DISPLACEMENT MONITORING CENTRE. NORWEGIAN REFUGEE COUNCIL, 2015).

${ }^{60}$ Para cada uma das frases que compõem essa noção de moradia digna, apresentamos na Nota de Rodapé, as sentencias que invocam essas frases.

61 (C.C. T-045, 2014); (C.C. T-270, 2014); (C.C. T-176, 2013); (C.C. T-047, 2011); (C.C. T-044, 2010); (C.C. T-585, 2006); (C.C. C-936, 2003).

62 (C.C. T-019, 2014); (C.C. T-045, 2014); (C.C. T-049, 2014); (C.C. T-099, 2014); (C.C. T-244, 2014); (C.C. T-625, 2014); (C.C. T-680, 2014); (C.C. T-781, 2014); (C.C. T-825, 2014); (C.C. T-885, 2014); (C.C. C-370, 2014); (C.C. T-176, 2013); (C.C. T-409, 2013); (C.C. T-602, 2013); (C.C. T-761, 2013); (C.C. T-264, 2012); (C.C. T-349, 2012); (C.C. T-501, 2012); (C.C. T-740, 2012); (C.C. T-851, 2012); (C.C. T-857, 2012); (C.C. T-927, 2012); (C.C. T-106, 2011); (C.C. T-238A, 2011); (C.C. T-675, 2011); (C.C. T-702, 2011); (C.C. T-761, 2011); (C.C. T-573, 2010); (C.C. T-079, 2008); (C.C. T-473, 2008); (C.C. T-585, 2008); (C.C. T-646, 2007); (C.C. T-1017, 2007); (C.C. T-894, 2005); (C.C. T-1091, 2005); (C.C. T-791, 2004); (C.C. T-958, 2001); (C.C. C-936, 2003).

63 (C.C. T-099, 2014); (C.C. T-270, 2014); (C.C: T-432, 2014); (C.C. T-721, 2014); (C.C. T-851, 2014); (C.C. T-409, 2013); (C.C. T-047, 2011); (C.C. T-675, 2011); (C.C. T-761, 2011); (C.C. T-044, 2010); (C.C. T-585, 2008). 
las adversidades del clima ${ }^{64}$. Con prestación eficiente y planificada de los servicios públicos domiciliarios ${ }^{65}$ y servicios públicos asistenciales $^{66}$. Con condiciones adecuadas ${ }^{67}$ que no pongan en peligro la vida y la integridad física de sus ocupantes ${ }^{68}$. Vivienda habitable; es decir, que cumpla con los requisitos mínimos de higiene, calidad y espacio ${ }^{69}$. Adecuación de las viviendas según la discapacidad ${ }^{70}$. Que se puedan costear los gastos que exige la obtención de una vivienda digna ${ }^{71}$. Un espacio elemental de privacidad y de intimidad ${ }^{72}$, sin una intromisión indebida en el espacio privado, o interferencia ilegal o arbitraria ${ }^{73}$. Con protección contra el hostigamiento o la invasión irregular ${ }^{74}$. Que le permita salvaguardar su dignidad, y sus demás derechos y libertades ${ }^{75}$. Que los grupos más vulnerables de la sociedad tengan prioridad para garantizar el acceso a los recursos necesarios para conseguirla ${ }^{76}$. Que se pueda ejercitar con libertad el derecho a vivir en seguridad, paz y dignidad ${ }^{77}$. Que le permita a un individuo desarrollar en condiciones dignas su proyecto de vida ${ }^{78}$. Lugar

64 (C.C. T-045, 2014); (C.C. T-270, 2014); (C.C: T-432, 2014); (C.C. T-625, 2014); (C.C. T-721, 2014); (C.C. T-851, 2014); (C.C. T-176, 2013); (C.C. T-409, 2013); (C.C. T-534, 2013); (C.C. T-566, 2013); (C.C. T-631, 2013); (C.C. T-740, 2012); (C.C. T-047, 2011); (C.C. T-106, 2011); (C.C. T-484, 2011); (C.C. T-675, 2011); (C.C. T-761, 2011); (C.C. T-044, 2010); (C.C. T-079, 2008); (C.C. T-585, 2008); (C.C. T-585, 2006); (C.C. C-936, 2003); (C.C. T-262, 2007).

65 (C.C. T-016, 2014); (C.C. T-028, 2014); (C.C. T-197, 2014); (C.C. T-244, 2014); (C.C: T-790, 2014); (C.C. T-825, 2014); (C.C. T-971, 2014); (C.C. T-473, 2008); (C.C. T-646, 2007); (C.C. T-585, 2006); (C.C. C-936, 2003).

66 (C.C. T-825, 2014); (C.C. T-473, 2008); (C.C. T-646, 2007); (C.C. T-585, 2006); (C.C. C-936, 2003).

67 (C.C. T-049, 2014); (C.C. T-409, 2013); (C.C. T-631, 2013); (C.C. T-740, 2012); (C.C. T-675, 2011); (C.C. T-484, 2011); (C.C. T-646, 2007).

68 (C.C. T-045, 2014); (C.C. T-197, 2014); (C.C. T-625, 2014); (C.C. T-680, 2014); (C.C. T-749, 2014); (C.C. T-825, 2014); (C.C. T-409, 2013); (C.C. T-566, 2013); (C.C. T-740, 2012); (C.C. T-106, 2011); (C.C. T-484, 2011).

69 (C.C. T-749, 2014); (C.C. T-106, 2011); (C.C. T-484, 2011).

70 (C.C. T-270, 2014).

71 (C.C. T-019, 2014); (C.C. T-781, 2014); (C.C. T-825, 2014); (C.C. T-643, 2006); (C.C. C-936, 2003).

72 (C.C. T-099, 2014); (C.C. T-270, 2014); (C.C: T-432, 2014); (C.C. T-721, 2014); (C.C. T-851, 2014);

(C.C. Auto 099, 2013); (C.C. T-176, 2013); (C.C. T-409, 2013); (C.C. T-631, 2013); (C.C. T-047, 2011); (C.C. T-675, 2011); (C.C. T-761, 2011); (C.C. T-044, 2010); (C.C. T-585, 2008).

73 (C.C. T-187, 2014); (C.C. T-197, 2014); (C.C. T-672, 2014); (C.C. T-825, 2014); (C.C. T-589, 1998); (C.C. T-394, 1997); (C.C. T-210, 1994).

74 (C.C. T-825, 2014).

75 (C.C. T-270, 2014); (C.C: T-432, 2014); (C.C. T-721, 2014); (C.C. T-851, 2014); (C.C. Auto 099, 2013); (C.C. T-176, 2013); (C.C. T-409, 2013); (C.C. T-047, 2011); (C.C. T-106, 2011); (C.C. T-484, 2011); (C.C. T-675, 2011); (C.C. T-761, 2011); (C.C. T-044, 2010); (C.C. T-585, 2008).

76 (C.C. T-019, 2014); (C.C. T-218, 2014); (C.C: T-432, 2014); (C.C. T-680, 2014); (C.C. T-781, 2014); (C.C. T-833, 2014); (C.C. T-885, 2014); (C.C. C-370, 2014); (C.C. C-936, 2003).

77 (C.C. T-045, 2014); (C.C. T-454, 2012); (C.C. T-740, 2012); (C.C. T-088, 2011).

78 (C.C. T-019, 2014); (C.C. T-045, 2014); (C.C. T-049, 2014); (C.C. T-099, 2014); (C.C. T-625, 2014); (C.C. T-781, 2014); (C.C. T-825, 2014); (C.C. T-938A, 2014); (C.C. C-370, 2014); (C.C. Auto 099, 2013); (C.C. T-409, 2013); (C.C. T-602, 2013); (C.C. T-761, 2013); (C.C. T-264, 2012); (C.C. T-349, 2012); (C.C. T-740, 2012); (C.C. T-851, 2012); (C.C. T-927, 2012); (C.C. T-106, 2011); (C.C. T-238A, 2011); (C.C. T-675, 2011); (C.C. T-702, 2011); (C.C. T-761, 2011); (C.C. T-573, 2010); (C.C. T-079, 2008); 
donde se desarrolla gran parte de la vida de las personas que la ocupan, por lo que adquiere importancia en la realización de la dignidad del ser humano ${ }^{79}$ (Corte Constitucional de Colombia C.C.) Sentencias citadas nas Notas de Rodapé.

A noção do direito à moradia digna exposta nas Sentencias da Corte Constitucional da Colômbia é invocada como direito constitucionalizado no Artigo 51 da Constituição dessa nação. Ao ser desvendada essa noção para esse país, possibilitou-nos descobrir que ela é a expressão de variados instrumentos de direito internacional, evidenciando a permeabilidade dos direitos, ou o que é chamado na Colômbia de Bloque de Constitucionalidad ${ }^{80}$. Dos principais instrumentos que se veem refletidos nessa noção, temos: o "Direito à Moradia Adequada" e os seus sete elementos da Observação Geral no4 do Pidesc (1991), bem como outros instrumentos jurídicos de direito internacional, tais como a Observação Geral no7 do Pidesc (1997), os princípios da "Moradia Saudável" da Organización Mundial de la Salud (OMS) (1990), os "Princípios Pinheiro" para o deslocamento de população (2005), e a Observação Geral nำ15 (2002) do Pidesc a respeito do "Direito à Agua".

Sobre o Pidesc de 1991, como o instrumento mais invocado nas sentencias, e o que consideramos de maior influxo nessa noção de direito à moradia digna, a sentencia C-936 (2003) arrumou em dois grupos os sete elementos desse instrumento, tornando-se um precedente para os julgamentos até hoje. Do mesmo modo, a Defensoría del Pueblo da Colômbia enuncia essa classificação nas suas pesquisas sobre a delimitação desse direito. Os dois grupos são: Grupo 1) que congrega condições de habitação: (ii) a disponibilidade de serviços, os materiais e infraestrutura, (iv) a habitabilidade, (vi) a localização adequada e (vii) a adequação cultural. Grupo 2) que busca a segurança no desfrute da moradia e que abrange: (i) segurança jurídica da posse, (iii) economicidade, e (v) acessibilidade econômica (2009). No Apêndice $A$, apresentamos, na forma de um compêndio, os instrumentos jurídicos internacionais em permeabilidade com o direito à moradia. ${ }^{81}$.

(C.C. T-585, 2008); (C.C. T-1017, 2007); (C.C. T-894, 2005); (C.C. T-1091, 2005); (C.C. T-791, 2004); (C.C. T-958, 2001).

79 (C.C. T-045, 2014); (C.C. T-197, 2014); (C.C. T-625, 2014); (C.C. T-534, 2013); (C.C. T-566, 2013); (C.C. T-740, 2012); (C.C. T-079, 2008).

${ }^{80}$ Sobre o que significa a permeabilidade dos direitos e o Bloque de Constitucionalidad, ver Item 4.3.2.1.

${ }^{81}$ A Defensoría del Pueblo da Colômbia revisa sob o Bloque de Constitucionalidad, e que Leckie (1992) estabelece em termos mais gerais como a permeabilidade dos direitos, os seguintes instrumentos jurídicos internacionais a respeito do direito à moradia: Declaração Universal dos Direitos do Homem (Dudh), 1948; Convenção sobre o Estatuto dos Refugiados, 1951; Convenção Internacional sobre a Eliminação de Todas as Formas de Discriminação Racial, 1965; Pacto internacional de Direitos Civis e Políticos (PDCP), 1966; Pacto Internacional de Direitos Econômicos, Sociais e Culturais (Pidesc), 1966; Declaração Americana sobre os Direitos e Deveres do Homem (Dadh), 1948; Convenção sobre a Eliminação de Todas as Formas de Discriminação contra as Mulheres, 1979; Protocolo de San Salvador, 1988; Convenção sobre os Direitos da Criança, 1989; Convênio no 169 da OIT sobre Povos 


\begin{tabular}{|l|l|l|}
\hline \multicolumn{2}{|c|}{ Classificação em dois grupos dos sete elementos do Pidesc de 1991, feita pela Corte } \\
Constitucional da Colômbia
\end{tabular}

Indígenas e Tribais em Países Independentes, 1989; Convenção Internacional sobre a Proteção dos Direitos de Todos os Trabalhadores Migrantes e suas Famílias, 1990. As normas de soft law consideradas pela Defensoría para a delimitação do conteúdo à moradia adequada como Bloque de Constitucionalidad são: Declaração sobre o progresso e desenvolvimento na economia social, 1969; Declaração de Vancouver sobre Assentamentos Humanos - Hábitat I, 1976; Declaração de Istambul sobre Assentamentos Humanos - Hábitat II, 1996; Princípio de Limburgo sobre a implementação do Pidesc, 1986; Declaração sobre o Direito ao Desenvolvimento, 1986; Princípio de Maastricht sobre as Violações dos Direitos Econômicos, Sociais e Culturais, 1997; Princípios Orientadores sobre a Restituição de Moradias e o Patrimônio dos Refugiados e as Pessoas Deslocadas ou Principio Pinheiro 2005 (2009, p. 26).

Estas normas de soft law "Trata-se de manifestações que de forma genérica têm-se incluído no termo anglo-saxão soft law, pelo qual se designa 'uma série de normas, ainda que não constituam uma fonte jurídica obrigatória para os Estados, constituem uma guia para a compreensão dos deveres jurídicos pela ratificação do Pidesc'." (DEFENSORÍA DEL PUEBLO, 2009, p. 26, tradução nossa), quem cita a (PISARELLO, 2003, p. 116). 


\begin{tabular}{|l|l|l|}
\hline \multicolumn{2}{|c|}{ Classificação em dois grupos dos sete elementos do Pidesc de 1991, feita pela Corte } \\
Constitucional da Colômbia
\end{tabular}

Quadro 5.1 - Classificação em dois grupos dos sete elementos do Pidesc de 1991, feita pela Corte Constitucional da Colômbia.

Fonte: Elaboração própria com suporte nas citações referidas.

Obs.: Essa classificação em dois grupos é invocada nas sentencias da Corte Constitucional da Colômbia desde 2003

\subsection{Do direito de explorar as terras conquistadas ao direito à moradia digna. Síntese desde o âmbito jurídico da Colômbia}

A respeito da gênese e evolução do direito à habitação na Colômbia, no tempo da colônia e sob o regime das Leyes de Indias de 1680, o direito à moradia poderia ser compreendido como o direito a explorar um território por parte do colono, a partir da fundação, construção e povoamento de uma vila; para depois ser considerado como o direito de propriedade, desde as primeiras Constituições da Colômbia, até se estabelecer como o direito à moradia digna, na Constituição vigente de 1991; ainda que nessa Constituição também esteja instaurado o direito de propriedade.

No tocante às Constituições vigentes, a da Colômbia instituiu o "direito à moradia digna", enquanto a da Espanha foi o "direito à moradia digna e adequada". Nas duas Cartas Políticas, e desde as primeiras Constituições da Colômbia, que datam de 1810, a moradia é inviolável, estipulam o direito à propriedade privada, à liberdade para escolher o lugar de residência e à livre circulação no território nacional e o direito à segurança física; com similaridade no conteúdo dos artigos. A Carta vigente da Colômbia institui a democracia participativa, substituindo a democracia representativa que vinha das anteriores, contexto que possibilitou instaurar nessa Constituição e aplicar com posterioridade, figuras jurídicas como a acción de tutela, desde a qual um habitante, quando sente que os seus direitos Ihe são desrespeitados, pode interpor 
uma demanda perante um juiz, na busca de uma decisão para que sejam garantidos esses direitos. A Corte Constitucional da Colômbia, como um dos quatro Tribunais de Alta desse país, tem a função de revisar, na forma que a Lei determinar, as decisões judiciais que estão relacionadas com a acción de tutela dos direitos constitucionais; razão pelo que esse Tribunal é um agente de alta relevância nesta pesquisa.

$\mathrm{Na}$ evolução da natureza jurídica do direito à moradia, encontramos que nos primeiros anos das sentencias - desde 1992 - a habitação foi considerada pela Corte Constitucional um direito social de natureza prestacional e garantido segundo o orçamento do Estado. Depois de 1995, nas sentencias mostra-se, em algumas ocasiões, um vínculo dos direitos sociais com os direitos fundamentais, desde que 0 prejuízo de tal situação descrita nas sentencias possa ter como resultado a ameaça ou violação dos direitos fundamentais do requerente. Porém, observamos que, para que isso seja possível, é imprescindível a invocação de outros instrumentos de direito internacional, ou seja, a aplicação da permeabilidade dos direitos, questão que a Corte Constitucional da Colômbia admite nas sentencias de tutela como bloque de constitucionalidad, para basear suas decisões a respeito da violação dos direitos.

Entre 1998 e 2003, o direito à moradia retorna para ser considerado de natureza prestacional desde a discussão do recálculo de créditos hipotecários, por causa da bolha imobiliária - ocorrida no final da década de 1990 na Colômbia -. O tópico foi discutido a partir dos interesses da banca e não do morador que perde seu domićlio, não se arriscou qualquer noção de direito à moradia, além de que se expôs nas sentencias que o Estado não teve qualquer responsabilidade nessa situação.

A Corte Constitucional aceitou um carácter de fundamentalidade a respeito do direito à moradia digna na sentencia C-936 (2003), baseada nos elementos do Pidesc de 1991, e, para futuras decisões, neste e em outros instrumentos de direito internacional, desde que o direito à moradia fosse considerado fundamental, pela relação de fato com o direito à vida em condições dignas. A Corte Constitucional da Colômbia estabeleceu que seria necessário analisar as circunstâncias que cercavam o caso, para determinar se a necessidade de habitação carregava consigo elementos que ameaçavam a vida ou a dignidade de quem procurava ajuda desse Tribunal desde sentencias.

Sobre a noção do direito à moradia digna para a Colômbia, as sentencias de 1992 não a apresentaram de forma alguma. A T-382 (1993) forneceu uma noção na qual este direito envolve o reconhecimento da dignidade humana, que se traduz em um conjunto de condições materiais e espirituais contidas na existência do ser humano para se viver com melhor qualidade, e no qual este teto deve oferecer o básico: abrigo para proteger a saúde e manter o conforto. 
Assim, a Corte Constitucional da Colômbia considera que o direito à moradia digna, a partir das sentencias de 2003, é mais do que ter um teto sobre sua cabeça, é um lugar próprio ou de terceiros, onde se passa a noite, guarda-se contra as adversidades do clima. Com fornecimento planejado e eficiente dos serviços básicos. Com condições que não ponham em perigo a vida e a integridade física de seus ocupantes. Uma moradia habitável, ou seja, que atende aos requisitos mínimos de qualidade, higiene e espaço. Adaptação dos domicílios, de acordo com as deficiências dos moradores, e que estes possam pagar as dívidas que exige a obtenção de uma moradia digna. Um espaço de privacidade e intimidade, sem uma intromissão indevida no espaço privado, ou interferência ilegal ou arbitrária. Que os grupos mais vulneráveis da sociedade tenham prioridade para que Ihes seja garantido o acesso aos recursos necessários para se obter uma moradia. Que se tenha a proteção contra a invasão ou o assédio. Lugar em que se possibilite salvaguardar a sua dignidade, e seus outros direitos e liberdades. Em que se possa exercer livremente o direito de viver em segurança, paz e dignidade, para permitir que um indivíduo vá desenvolver seu projeto de vida em condições dignas. Lugar onde é desenvolvida grande parte da vida das pessoas que a ocupam, pelo qual se torna importante na realização da dignidade do ser humano. Essa noção do direito à moradia digna da Colômbia evidencia a influência, principalmente, dos sete elementos do Pidesc de 1991 e do Pidesc de 1997 sobre deslocamentos forçados, além de uma invocação constante ao respeito à dignidade.

Sobre a situação específica da Colômbia tal como o deslocamento forçado devido ao seu conflito armado interno, considera-se a existência de obrigações que as autoridades deveriam assegurar, relativas ao direito à moradia para população deslocada pelo conflito, razão pelo qual nas sentencias, a partir de 2009, proveramse uma noção de direito à moradia para esta situação, com critérios de auxílio para este tipo de população, cujo influxo veio dos Princípios Pinheiro de 2005, e da Observação $\mathrm{N}^{\circ} 7$ do Pidesc de 1997 sobre deslocamentos forçados. 


\section{Capítulo 6}

\section{ELEMENTOS SOCIOESPACIAIS EM SENTENCIAS DE TUTELA DA COLÔMBIA, COMO CONTEÚDO DO DIREITO À MORADIA DIGNA}

\subsection{Introdução}

Um âmbito que busca delimitar a noção do direito à moradia é a jurisprudência, motivo pelo que no Capítulo 5 revisamos desde as Constituições da Colômbia e as sentencias de tutela da sua Corte Constitucional que argumentavam a violação ao direito à moradia, a gênese, a evolução e a natureza desse direito para a Colômbia, até se enxergar a sua noção atual; para encontrar que esse direito poderia ser considerado fundamental, quando estivesse em ameaça um direito fundamental como é a vida e a integridade do homem. Mais uma descoberta desde esse contexto colombiano desenvolvido no Capítulo 5, foi a invocação ao desrespeito à dignidade, tanto na noção deste direito, quanto na argumentação nas sentencias, quando violado o direito à habitação. Tal descoberta converteu-se em pretexto que coadjuvou à perspectiva de indagar, na jurisprudência, pela relação da dignidade com o espaço.

Neste Capítulo 6, analisamos as sentencias enquanto "demanda", no sentido do que o demandante percebe, são os fatos, narrados nessas figuras jurídicas, que violam o direito à moradia, e, por conseguinte, o tipo de lesão como consequência da violação desse direito; mas tendo em consideração que o conteúdo das sentencias é mediado por um juiz. Outros tópicos que poderiam ser revisados desde sentencias de tutela desse Tribunal é a decisão adotada pelo juiz, ou o que ocorre com o demandante ou o demandado depois dessa decisão, mas isso não é objetivo desta tese. Deste modo, não acrescentamos informação, em estrito, sobre jurisprudência. O que fizemos neste Capítulo foi pôr em evidência como o do direito à moradia na Colômbia está sendo praticado nas sentencias na maneira de uma demanda.

Uma descoberta a partir da análise das sentencias é que a Corte Constitucional da Colômbia construiu um conteúdo material da dignidade com três objetos de proteção, estipulados desde a sentencia T-881 (2002); desenvolvimento considerado importante porque em sentencias subsequentes, evidencia-se que se viola o direito à moradia, entre outros direitos, e, por sua vez, há um desrespeito à dignidade, quando algum 
desses objetos de proteção é lesado. Contudo, para se entender essa vulneração aos objetos de proteção da dignidade e a violação ao direito à moradia, precisamos abordar a noção de dano e lesão desde o jurídico, para o qual revisamos autores da área da jurisprudência para esclarecer assuntos e noções associadas com a violação a um direito; para finalmente, desvendar o que é lesado nestes três objetos de proteção da dignidade, quando o direito à habitação é violado.

A questão sobre a demanda é um objeto de estudo do campo da jurisprudência, mas também tem afinidade com as ciências sociais aplicadas, porém não encontramos sua abordagem, como está sendo realizada nesta pesquisa, desde nenhum desses campos de conhecimento. Convém esclarecer que a base da informação analisada neste capítulo é um conjunto de sentencias da Corte Constitucional da Colômbia, sobre o direito à moradia, categorizadas com instrumentos de classificação do campo da jurisprudência, e conforme os elementos que contêm uma sentencia.

Uma dificuldade com as sentencias de tutela, foi a necessidade de inferir o suporte de argumentação a respeito da violação aos direitos, para o qual precisávamos estar cientes de que não é objetivo desse tipo de textos apresentar esse suporte teórico; causa pela qual adotamos autores da área do jurídico, que possibilitaram compreender a base das construções jurídicas a respeito da violação ao direito à moradia, que esse Tribunal da Colômbia utiliza nas sentencias.

Antecedendo a análise dos dados empíricos, neste Capítulo, apresentamos a abordagem metodológica das sentencias, desde as quais estabelecemos elementos socioespaciais recorrentes quando o direito à moradia era descumprido; e que foram plotados no que nomeamos como esquemas argumentativos. Para logo mostrar a sua relação da noção do direito à moradia digna da Colômbia, com instrumentos jurídicos de direito internacional, exibindo a permeabilidade e a colateralidade dos direitos; desde o qual evidenciamos as condutas do demandado que viola o direito à habitação. No final, apresentamos os elementos socioespaciais desde os quais é praticado o direito à moradia digna, desde a jurisprudência da Colômbia.

\subsection{Esquemas argumentativos desde sentencias da Corte Constitucional da Colômbia sobre a violação ao direito à moradia digna. Abordagem metodológica}

As sentencias da Corte Constitucional da Colômbia são os documentos de análise, para este Capítulo, com foco na questão da demanda por violação ao direito à moradia. Assim, esta pesquisa analisa os conflitos habitacionais interpostos em acciones de tutela. A delimitação temporal das sentencias obedece a que a acción de tutela, como figura jurídica, foi instaurada na Constituição vigente da Colômbia de 
1991, e, assim, as primeiras sentencias datam de 1992. Motivo pelo qual as revisamos a partir deste período até 2014 , ano em que concluímos a coleta de dados para esta pesquisa. As sentencias são de domínio público através do site da Corte Constitucional da Colômbia, considerando que essas são as que contêm os fatos da demanda e a decisão do juiz, que devem ser revisadas por Magistrados desse Tribunal, e expostas no site dessa instituição.

Encontramos que dois agentes principais atuam na narração dos fatos nas sentencias a respeito da demanda: 1) o demandante, que pode ser um indivíduo, um grupo de pessoas com uma petição comum, ou uma empresa, que demanda outro sujeito de direitos, e 2) o demandado que poderia ser uma pessoa ou um grupo, uma empresa, um agente financeiro, uma lei ou regulação ou algum órgão do Estado. O primeiro considera que por ações do demandado, o seu direito à moradia é desrespeitado.

No que diz respeito à classificação e leitura sistematizada de sentencias, o livro "El derecho de los Jueces", de López (2006), fornece uma metodologia para construir "cenários constitucionais", ou seja, a agrupação e classificação de sentencias que discutem temas jurídicos ou direitos semelhantes. Esclarecemos que as ferramentas deste autor foram um apoio para estabelecer o conjunto de sentencias de análise, mas não forneceram instrumentos para a análise da narração do demandante sobre a violação e os tipos de lesões gerados; assim como também não possibilitaram indagar pelos elementos recorrentes quando o direito à moradia tem sido violado.

O que López (2006) nomeia como "cenários constitucionais", nesta tese foram estabelecidos como esquemas argumentativos. Estes são "formas de argumentos ou estruturas de inferência, que representam os tipos mais comuns de estrutura de argumentos usados no discurso cotidiano e também em contextos como a argumentação jurídica e a argumentação científica" Walton et al ${ }^{82}$ (2008 apud MARRAUD, 2016, p. 2, tradução nossa). Esses esquemas argumentativos podem ser classificados no que se considera, segundo Marraud (2016, p. 15), como vínculos de sucessão causa-efeito, em que, dado um evento, permite-se visualizar um efeito que resultaria do evento; além de que se vai permitir apreciar um evento em conformidade com suas consequências favoráveis ou desfavoráveis. Podemos observar os esquemas argumentativos no Apêndice D, Figuras D1 a D9.

Seguindo a metodologia de López, o primeiro passo, para construirmos os esquemas argumentativos, foi encontrar as sentencias de tutela do ano 2014 de importância para esta pesquisa. Motivo pelo qual fizemos uma busca sob a palavra-chave "vivienda

82 Walton, D.N. Reed C.A. e Macagno, F. Argumentation Schemes, p.1. Nueva York: Cambridge University Press. 2008. 
digna", no "índice temático" do site da Corte Constitucional da Colômbia ${ }^{83}$. Após esta primeira busca, estabelecemos 54 julgamentos de 2014 como os mais relevantes. As sentencias não relevantes foram definidas quando o fato não discutiu questões relacionadas com a habitação, ainda que houvesse sido invocado na sentencia o direito à moradia, aos serviços básicos ou a um ambiente adequado. Sentencias com pouca clareza no fato também não foram consideradas para a análise.

A escolha de sentencias nas quais o direito à moradia digna tinha sido violado deveuse a uma estratégia de delimitação de objeto de estudo; e evitamos, desta forma, mais outros casos conexos com a violação a esse direito, o que resultava interminável e muito amplo para os objetivos desta pesquisa. No entanto, esses e outros casos conexos tem relação com a permeabilidade dos direitos, porquanto a violação de um direito não se concentra só neste direito. Sua violação gera consequências com nível de lesões que poderiam abranger outros direitos, o que chamamos aqui da colateralidade dos direitos.

Destas sentencias de 2014, nomeadas nesta pesquisa como "sentencias fonte", foram extraídas as sentencias com casos semelhantes, designadas aqui como "sentencias caso", e invocadas como um "precedente" ou uma reiteração da jurisprudência nas sentencias fonte. Com as "sentencias fonte" e as "sentencias caso", foi construída uma árvore de julgamentos em violação ao direito à moradia, o que López (2006) chama um nicho citacional sobre um tema jurídico ou um direito, para nosso caso, o direito à habitação, para estabelecer 107 documentos para sua análise.

A seguir, separamos essa grande árvore composta por "sentencias fonte" e por "sentencias caso", de acordo com os temas que discutiam as sentencias de 2014, gerando uns nichos citacionais mais específicos, os quais poderiam estar compostos por várias sentencias de 2014 e suas correspondentes "sentencias caso". López estabelece que as árvores, segundo os temas que abordam as "sentencias fonte", correspondem a "linhas de jurisprudência" ou problema jurídico bem definido, sob o qual se abre um espaço amplo de decisões possíveis. No entanto, é importante esclarecer que não é o objetivo desta pesquisa indagar pelas soluções possíveis para cada linha de jurisprudência. Até esse ponto da análise, a classificação das sentencias conta com apoio da metodologia de López (2006).

Levamos em consideração que cada um dos temas encontrados nas sentencias de 2014, e desde os quais se criaram árvores mais específicas, era a pretensão do demandante a respeito de um objeto mais geral, motivo pelo qual nomeamos esses

${ }^{83}$ Site da Corte Constitucional de Colombia: http://www.corteconstitucional.gov.co/relatoria/. Online a 30 de abril de 2016. 
temas como a "pretensão do demandante", e ao objeto mais geral como o "objeto espacial em litígio". Assim sendo, o objeto espacial em litígio encabeça cada esquema argumentativo como caso no qual o direito à moradia é violado, e o qual pode conter várias pretensões sobre esse objeto.

Depois de ter construído os esquemas argumentativos por objetos espaciais em litígio, precisávamos determinar quais outros elementos das sentencias eram os relevantes, para visualizar as ações que fazem com que a pretensão não fosse garantida. Deste modo, os elementos que encontramos, e que precisavam ser visualizados e levantados foram: a ação ou resposta do demandado descrita na demanda, nomeada aqui como "conduta"; os elementos socioespaciais nos quais o demandado escuda a sua conduta; e o tipo de lesão desde o jurídico.

Posto isso, descobrimos que os elementos recorrentes de uma sentencia, que, expõem a percepção do demandante a respeito da violação ao direito à moradia, correspondiam a elementos socioespaciais tais como: (a) o objeto espacial em litígio, que é um elemento geral ao qual o demandante procura acessar ou obter, e sobre o qual o demandado tem o controle; (b) a pretensão do demandante a respeito do objeto espacial em litígio, que, por sua vez, mostra o procedimento associado com esse objeto; (c) a conduta, como a ação ou resposta do demandado - e que o demandante percebe - que é a causa da violação ao direito à habitação, e em consequência, manifesta-se em (d) tipos de lesão desde o âmbito jurídico. ${ }^{84}$

$\mathrm{Na}$ análise da descrição dos fatos a respeito das condutas, deparamo-nos com que os demandados escudavam-se em três tipos de elementos socioespaciais para não diminuir ou cessar essa conduta: $\left(\mathbf{c}^{1}\right)$ condutas escoradas nas competências e no perfil financeiro do demandado; e nos processos reguladores e nas leis; $\left(\mathbf{c}^{2}\right)$ condutas amparadas em situações espaciais sobre as quais os demandados dizem não ter controle; $\left(c^{3}\right)$ condutas resguardadas na atual situação de vulnerabilidade do demandante.

Esses elementos recorrentes de uma sentencia, que, expõem a percepção do demandante e do juiz a respeito da violação ao direito à moradia, e que correspondem a elementos socioespaciais, constituíram-se em categorias de análise, o que tornou possível sintetizar o conteúdo destes julgamentos, para, logo, relacioná-las por meio

${ }^{84}$ Esclarecemos que os tipos de lesão foi um tema que emergiu para ser examinado quando descobrimos esses elementos recorrentes nas situações nas quais o direito à moradia é violado; razão pelo qual baseamos a revisão desse tópico nas noções expostas por Fernández-Sessarego. Esses tipos de lesão também evidenciam o que a Corte Constitucional da Colômbia tem instaurado nas suas sentencias como três objetos de proteção da dignidade. Tanto o referido ao tipo de lesão, quanto ao dos objetos de proteção da dignidade, são desenvolvidos no Item 6.3 e 6.4 . 
de uma série de preposições e conceituar sobre estas. Esse procedimento é conhecido como codificação sob o método de análise de conteúdo, técnica de pesquisa que permite construir inferências ou dar explicações, aplicadas a um contexto (BARDIN, 2002; KRIPPENDORFF, 1990). O software Atlas.ti foi o suporte para a codificação e para a análise qualitativa das sentencias.

Foi necessário revisar nas sentencias, as características do demandante e do demandado, já que a Constituição Política da Colômbia instaura critério diferenciado para a população vulnerável ${ }^{85}$ como a constatada nas sentencias: idoso, sem renda, com e sem crianças dependentes; mãe ou pai chefe de família, com renda mínima produto de trabalho informal ou sem renda, com crianças saudáveis, deficientes ou com doença crônica ou terminal; adultos com doença física ou mental, crônica ou terminal; povos indígenas expulsos das suas terras, sem renda. Além das condições da população acima apontadas, encontramos que muitos destes requerentes estavam em uma situação de deslocamento forçado.

Organizações ou movimentos de moradia da Colômbia não foram encontrados como agentes demandantes ou demandados; não existe neste país organizações sociais nacionais cujo objetivo seja especificamente a luta pela moradia. Existem múltiplas organizações não governamentais que trabalham para a promoção e defesa dos direitos humanos na Colômbia, e entre as suas linhas de trabalho pode estar o direito à moradia que, ocasionalmente, pode ser sua linha principal. Algumas ONGs internacionais como Centre on Housing Rights an Evictions (COHRE), cujo foco é a moradia, tem sede na Colômbia, no entanto, sua ênfase é a defesa do acesso à habitação como reparação às violações aos direitos humanos, deixadas pelo conflito armado interno, para a população em situação de deslocamento forçado, e não como política social ${ }^{86}$.

85 Segundo o Departamento Nacional de Planeación (DNP) da Colômbia, a população que é considerada vulnerável para acessar aos programas de moradia do governo é a seguinte: "população que por seus baixos níveis educacionais, a instabilidade da renda e as características deficitárias das suas moradias tem um baixo nível de gestão e capacidade para lidar com a situação da mudança ou de acesso à moradia" (DNP, 2006, tradução nossa). Uma definição mais ampla de população vulnerável e não restrita a ter esse status para o acesso a necessidades básicas, proposta por agências multilaterais de voluntariado para emergências, é quando os mais vulneráveis são os compostos por mulheres, crianças, idosos, pessoas vivendo com HIV ou AIDS, e as minorias étnicas. [...] especialmente vulneráveis são as pessoas com deficiência, que podem ser definidas como pessoas que sofrem de diminuições físicas, sensoriais ou afetivas, ou com dificuldades de aprendizagem, o que faz com que seja mais difícil de usarem os serviços de suporte normal em casos de desastre. [...]. Pessoas vivendo com HIV/AIDS (PVHA) frequentemente sofrem de discriminação, e, portanto, é necessário manter uma rigorosa confidencialidade e fornecer proteção para elas. Esta doença debilitante lesa não apenas os indivíduos que a sofrem, mas também suas famílias e comunidades [...]. Em determinados contextos, algumas pessoas podem ser vulneráveis devido à sua afiliação étnica, religiosa ou política, ou porque estão deslocadas (SCHR, VOICE, ICVA, 2004, tradução nossa).

86 Uma explicação sobre a política social, a reparação, e a assistência humanitária na Colômbia: A política social tem seu foco em direitos sociais, sob a implementação de políticas públicas relacionadas 
Esse conjunto de elementos, recorrentes de uma sentencia, expõe a percepção do demandante e do juiz sobre a violação ao direito à moradia, e apresenta as condições que mostra a violação aos direitos habitacionais, não nomeados dessa maneira nas sentencias nem conceitualmente em pesquisas que debatem, a partir de sentencias, o direito à habitação ou direitos análogos, nas quais o espaço é um componente fundamental já que é o objeto em litígio.

\subsection{O dano e a lesão na violação ao direito à moradia e à dignidade}

Observamos na narração dos fatos nas sentencias uma descrição sobre a situação do demandante no momento de interpor a Acción de Tutela; no entanto, o que encontramos foi que essa situação do requerente referia-se a danos e lesões que ele sofria como consequência das condutas dos demandados, e que estes escudavam-se em elementos socioespaciais para não diminuir a própria conduta. Deste modo, essa questão do dano, como parte da violação a um direito, converteuse em perspectiva da análise nas sentencias. Pesquisando nesta linha, encontramos nas sentencias que o desrespeito à dignidade era invocado em algumas ocasiões, por sua vez, com a violação ao direito à moradia, quando a integridade, a vida e a dignidade estavam em perigo, e, assim, a moradia, como um direito social, constituía vínculo com os direitos fundamentais tais como a vida e a integridade. O tema do desrespeito à dignidade foi desenvolvido pela Corte Constitucional da Colômbia a partir de três objetos de proteção da dignidade, expostos na T-881 (2002) e considerados pelos juízes como precedente nas subsequentes sentencias.

Para compreender quanto ao dano gerado pela violação a um direito, foi preciso esclarecer algumas noções desde o jurídico da Colômbia, quando um direito fundamental é violado ou ameaçado por uma ação ou omissão de autoridade pública ou por particular. A violação implica o conceito de dano ou lesão. Viola-se um direito quando o bem jurídico que constitui o seu objeto é lesado por uma ação, e, dessa maneira, a pessoa em causa já foi vítima de ato ilegal, de dano. O direito é ameaçado, quando o mesmo bem jurídico ou a pessoa está sujeita a imediata probabilidade de

aos direitos à moradia, educação e saúde, a fim de garantir esses direitos sociais. As medidas de política social não pressupõem a existência de danos, mas uma necessidade insatisfeita, ou uma situação de discriminação ou marginalização de uma pessoa, ou de um grupo no acesso a bens básicos. A reparação tem como critério o fato de um ato ilícito, a ocorrência de um dano antijurídico e graves violações dos direitos humanos. As medidas de reparação têm diferentes componentes restituição, compensação, reabilitação, satisfação e garantia de não-repetição. As medidas de assistência humanitária pressupõem uma situação de crise, causada por catástrofes naturais ou conflitos armados, colocando em risco as condições básicas de existência de pessoas lesadas por tal situação, motivo pelo qual as medidas de assistência humanitária têm um caráter assistencial e temporário, porque sua finalidade é garantir condições mínimas de subsistência daqueles que sofrem com a situação de crise (C.C. C-912, 2013). 
dano. Em termos de proteção dos direitos constitucionais fundamentais, 0 ato da ameaça é para determinar se os atos praticados vão em direção à violação de um direito, em decorrência das manifestações externas realizadas e claras da futura evolução para o dano (C.C. T-412, 1992).

Dois elementos a serem ressaltados quando um direito é violado: o dano e a lesão que a literatura jurídica apresenta em algumas ocasiões, como sendo elementos sinônimos e, portanto, indistintos. Porém nesta pesquisa vamos fazer distinção, apoiando-nos no pensamento de Fernández-Sessarego ${ }^{87}$. Assim, que conforme esse autor, o dano refere-se a um evento, ato ou circunstância negativo causado pela incidência de uma ação prejudicial; a lesão é a consequência derivada do dano, tanto no ser humano, quanto no seu patrimônio. Deste modo, o dano deve ser apreciado desde dois planos relacionados, em função da i) natureza do ente danado, que é o homem como sujeito de direito, e ii) em termos das consequências que tal dano tem causado na entidade danificada.

i) Conforme a natureza do ente danificado:

a) Dano subjetivo ou dano à pessoa é o que incide sobre o sujeito do direito. $\mathrm{A}$ lesão pode ser:

- na unidade psicossomática do ser humano, como uma lesão somática (no corpo) e/ou psíquica (na psique). Alguns autores a nomeiam como dano biológico;

- uma lesão biológica;

- uma lesão à saúde

- uma lesão no projeto de vida.

b) Dano objetivo ou lesão às coisas que integram o património das pessoas.

ii) Segundo as consequências que o dano tem causado na entidade danificada;

a) Lesão extra-pessoal, patrimonial ou material, que é quando o dano lesa de forma direta o patrimônio (bens econômicos) ou este é depreciado;

b) Lesão pessoal, não patrimonial ou extrapatrimonial, quando a lesão é no bem-estar da vítima, e que não pode ser observada nos bens; deste modo, a depreciação não pode ser apreciada de forma imediata em dinheiro. Pode se causar uma lesão:

- à moral que corresponde à esfera íntima, aos afetos, aos sentimentos;

- à saúde com prejuízos materiais ao corpo e ao bem-estar integral;

- às condições de existência, que cobre uma lesão: ○ à integridade física;

87 Carlos Fernández-Sessarego, peruano, advogado, Doutor em Direito, apresentou resultados inovadores e de implementação a nível operacional, atualmente incorporados como contribuições originais para a literatura jurídica, são as que dizem respeito à "teoria tridimensional do direito", ao "dano ao projeto de vida" e à "concepção sobre o sentido do direito para a vida humana" (FERNÁNDEZSESSAREGO, 2010). 
- fisiológica ou prejuízo para o prazer;
à vida em relação ${ }^{88}$. (FERNÁNDEZ-SESSAREGO, 2002; 1996). ${ }^{89}$

\subsubsection{Três objetos de proteção da dignidade: viver como quiser, viver bem e viver sem humilhação. A jurisprudência da Colômbia}

As sentencias analisadas sobre a violação ao direito à moradia e a noção do direito à moradia digna reiteram o respeito à dignidade. Na jurisprudência colombiana, o enunciado dignidade humana equivale "a um merecimento especial, que cada pessoa tem pelo fato de ser tal, e, assim, torna-se na faculdade que tem toda pessoa de exigir dos outros um tratamento compatível com sua condição humana. Desta forma, a dignidade se institui como um direito fundamental, de eficácia direta" (C.C. T572, 1999, tradução nossa).

A Corte Constitucional da Colômbia também expõe nas sentencias, que o conceito de dignidade se traduz na ideia de que não se é garantido qualquer direito, que a Constituição qualifica como fundamental, se um indivíduo é condenado a sobreviver em condições inferiores às que a natureza lhe designar como ser humano. Quanto a isso, o conceito de dignidade humana - adotado pela Constituição da Colômbia rejeita toda atitude depreciativa das necessidades corporais e espirituais, as quais merecem atenção em um Estado Social de direito como é a Colômbia, que reconhece no ser humano a razão para sua existência e a base e justificação da ordem jurídica. Contudo, não é que esse Tribunal procure negar a inerência da dignidade do homem, senão de integrar a essa noção um conceito normativo de dignidade humana, a partir de um conjunto de qualidades relacionadas com o meio social da pessoa, gerado em situações nas quais o ser humano desenvolve-se em sua vida cotidiana (C.C. T-881, 2002); (C.C. T-556, 1998).

Hoyos afirma, desde os direitos humanos, que a dignidade pode ter uma dimensão prática, quando expressa que todo ser humano está imerso em relações sociais, que são históricas, e entende-se que os direitos humanos são bens orientados a respeitar

\footnotetext{
${ }^{88}$ Mantilla de Valera expõe que a lesão "à vida em relação" tem sido nomeada com anterioridade como uma lesão fisiológica, porque não existia diferença entre o dano (dano-evento) e a lesão (danoconsequência) (2015).

89 Tanto o dano subjetivo a uma pessoa, quanto o dano às coisas, pode ter consequências patrimoniais ou extrapatrimoniais, ou apresentar simultaneamente os dois tipos de consequências. FernándezSessarego afirma que o motivo que levou alguns autores, e a ele mesmo, à atenção preferencial em torno à vítima do dano, perante a necessidade humana de que ela não fique sem reparação. Tanto para o dano subjetivo, quanto para a lesão pessoal, não há uma tradução direta e imediata em dinheiro. Para o caso do dano às coisas e a lesão extra-pessoal, a consequência desse dano pode se compensar em dinheiro, ou o objeto danificado pode ser substituído por um similar (FERNÁNDEZ-SESSAREGO, 2002; 1996).
} 
o homem como uma pessoa e a promover sua realização na esfera social; nesta perspectiva, os direitos humanos seriam, portanto, uma forma de expressar a reivindicação, correspondendo a que cada homem seja respeitado como pessoa e reconhecido como tal $(2005$, p. 197, 198). Ela esclarece que o direito pode aparecer sob regras, que restringem e obrigam, tais como pagar impostos, executar contratos; também aparece como aquilo que o sujeito tem para pretender alguma coisa, ou seja, uma faculdade de um sujeito para exigir de outros um benefício, ou o que a linguagem técnica jurídica chama de direitos subjetivos, tais como o direito à alimentação, à moradia, a expressar suas ideias livremente (p. 203). Ou seja, que o princípio de dignidade humana, como qualquer outro, tem um conteúdo universal que é mostrado no fato de serem estabelecidos alguns critérios orientadores, regras ou fórmulas para levá-los em conta na sua aplicação a um caso específico (HOYOS, p. 187). Para concluir com uma fórmula do princípio da dignidade humana, que ela define como que "todo homem tem que ser respeitado como uma pessoa e cada homem tem de ser reconhecido como uma pessoa" (p. 188, tradução nossa).

A Corte Constitucional da Colômbia, nas suas sentencias, referencia, em algumas ocasiões, o desrespeito à dignidade, quando acontece uma violação ao direito à moradia. Como não há uma delimitação clara do que é necessário ser respeitado para que se considere que a dignidade humana foi (des)respeitada, a Corte, por essa razão, instaurou o enunciado "dignidade humana" como uma entidade normativa, que poderia ser detectada a partir de três objetos de proteção, sobre os quais, essa instituição afirma, que podem ser considerados conteúdo material da dignidade: (I) a dignidade humana, entendida como autonomia ou possibilidade de projetar um plano de vida (viver como quiser); (II) a dignidade humana, entendida como certas condições materiais específicas de existência (viver bem); (III) a dignidade humana que se compreende como a intangibilidade dos bens não patrimoniais, a integridade física e a moral (viver sem humilhação) (C.C. T-881, 2002). Observamos que quando esses objetos de proteção são desrespeitados, contêm os tipos de lesão que FernándezSessarego $(2002 ; 1996)$ tem construído segundo as consequências que o dano causa no sujeito.

A seguir, apresentamos desde cada um dos objetos de proteção à dignidade, os tipos de lesões que poderiam ser gerados quando é lesado algum desses objetos, e o que significam cada um desses tipos de lesão. Acrescentando-se também os temas que a Corte Constitucional da Colômbia tem discutido desde esses objetos de proteção da dignidade; temas apresentados na T-881 (2002), e que nos Itens 6.3.1.1, 6.3.1.2 e 6.3.1.3 mostramos muito brevemente. No entanto, não encontramos estudos mais recentes que revisaram temas jurídicos associados com o direito à moradia, nos quais esses objetos de proteção tenham sido debatidos. Sobre o conteúdo interpretativo dos objetos de proteção à dignidade e os tipos de lesão quando esses objetos são vulnerados, corresponde a inferências da autora desta tese, porquanto essa 
informação não é fornecida pelas sentencias, mas estamos cientes de que não é o objetivo dessa figura jurídica apresentar o suporte teórico. Essas inferências foram construídas com base no pensamento de Fernández-Sessarego, no qual se aborda as noções de dano e a lesão; e sob a ferramenta de análise de conteúdo.

\subsubsection{Lesão ao projeto de vida - viver como quiser}

No objeto de proteção da dignidade entendida como autonomia ou possibilidade de projetar um plano de vida - viver como quiser -, conseguimos compreender que a intromissão ou o obstáculo ao projeto de vida é um dano subjetivo e é uma lesão pessoal. Em palavras de Fernández-Sessarego, o projeto de vida é como um destino ou direção que a pessoa dá a sua vida, e então decide viver de uma maneira ou de outra; mas a lesão ao projeto de vida, é um dano atual que pode comprometer em diferente extensão e intensidade, conforme o caso, o futuro da pessoa; e pode ter como consequência que a vida dela perca "sentido" a ponto de não continuar a viver com a mesma intensidade $(2002$, p. 24,26$)$. O dano ao projeto de vida é um dano atual que acompanha o sujeito durante sua jornada de vida; compromete a liberdade do sujeito para ser "ele mesmo" e não "outro", e incide sobre a liberdade do indivíduo a se realizar segundo sua própria livre decisão (1993, p. 11, aspas do autor). É um dano de tal magnitude que lesa, portanto, a maneira em que 0 sujeito decidiu viver, que trunca o destino da pessoa, que lhe faz perder o sentido da sua existência. Não é uma deficiência temporária nem permanente, mas é uma lesão cujas consequências têm um impacto em algo ainda mais importante para o sujeito, tais como seus próprios fins vitais, que dão razão e sentido à sua vida (1996, p. 86).

A pessoa lesada no que se refere ao exercício da sua liberdade, ingressa em um compreensível estado de desorientação, depressão, perda de segurança e de confiança em si mesmo, e na ausência de objetivos; a angustiante situação envolvendo a vítima pode levá-la à evasão por meio de uma dependência de drogas ou, em um caso limite, ao suicídio (FERNÁNDEZ-SESSAREGO, 2002, p. 27). O dano para o projeto de vida traz como consequência um colapso psicossomático de tal magnitude para o sujeito que afeta a sua liberdade, o que o frustra (1996, p. 83).

Revisando as categorias de Fernández-Sessarego, o dano ao projeto de vida faz alusão à lesão psicossomática, que abrange a lesão biológica e a lesão à saúde, e repercute no bem-estar da pessoa. A lesão biológica pode, segundo o autor, ser física e/ou psíquica; no qual o dano na psique é configurado pela "alteração ou modificação patológica do aparelho psíquico como resultado de um trauma" (FERNÁNDEZSESSAREGO, 1996, p. 74, tradução nossa). A lesão à saúde tem a ver com os danos causados ao bem-estar integral da pessoa que pode ser gerada por uma ou mais lesões (2002, p. 22); este autor delimita a definição de saúde com suporte na definição 
da OMS: a saúde é um estado de completo bem-estar físico, mental e social, e não meramente a ausência de doença ou de enfermidade ${ }^{90}$.

Deste modo, o que a Corte busca proteger com esse objeto de proteção é a liberdade de eleição de um projeto de vida; isto se concretiza na "possibilidade de escolher o próprio destino, quando a eleição não danifica diretamente a órbita dos direitos dos outros" (C.C. T-881, 2002, tradução nossa). Alguns dos temas que a Corte discute desde esse objeto de proteção e que expõe na T-881 de 2002, são: o pagamento de resgate de sequestrados; a despenalização da dose mínima para o consumo de drogas; a mudança de sexo para menor de idade; a eleição da eutanásia por enfermos devido as suas condições deploráveis de saúde.

\subsubsection{Lesão às condições materiais de existência - viver bem}

A alteração das condições materiais de existência - viver bem -, poderia ocasionar, segundo inferências construídas desde a análise das sentencias, e com suporte nos tipos de lesão de Fernández-Sessarego, uma lesão à integridade física, uma lesão fisiológica e uma lesão "à vida em relação", componentes de uma lesão pessoal. A integridade física corresponderia à capacidade das pessoas para manter intacto seu corpo e sua saúde; mas como lesão, prejudicaria a qualidade de vida. A lesão fisiológica ou prejuízo para o prazer é definido por Tamayo ${ }^{91}$ (1986 apud GARCÍA-VARGAS e PARRA-DÍAZ, 2007, p. 88), como a perda da capacidade de executar atividades vitais ou prazerosas que ainda não estão produzindo resultados econômicos, mas tornam a existência agradável; e suas manifestações são externas e permanentes. A lesão à "vida em relação" é uma lesão que uma pessoa padece na sua integridade psicofísica ou de saúde, e que resulta em uma diminuição nas possibilidades do sujeito exercer normalmente sua personalidade no ambiente social (GARCÍA-VARGAS e PARRA-DÍAZ, 2007, p. 89).

A promoção ou violação das condições materiais de existência tem a ver com instrumentos tangíveis que podem melhorar ou diminuir a qualidade de vida tais como: procedimentos, regulações, critérios, decisões que influenciam a mudança de uma condição espacial. Entre os temas que a Corte tem coberto desde este objeto de proteção e que estão compiladas na T-881 de 2002: a melhora das péssimas

\footnotetext{
${ }^{90}$ Essa definição de saúde da OMS, também é invocada no Artigo 12 do Draft Covenant on Economic, Social and Cultural Rights (CESCR) de 1955, no Artigo 13 do Pidesc de 1966 e no elemento (iv) habitabilidade, do Pidesc de 1991, o que se pode observar no Quadro 1.1.

Para a Constitución de la Organización Mundial de la Salud que contém essa definição sobre a saúde, ver (ORGANIZACIÓN MUNDIAL DE LA SALUD, 1946).

91 Tamayo, Javier. De la responsabilidad civil. T.2. Bogotá, Temis, p.144, 1986.
} 
condições espaciais e de habitabilidade das cadeias; o requerimento de que seja paga a aposentadoria a idosos ou a enfermos diminuídos em suas capacidades, porquanto essas situações restringem a disposição para o trabalho; enfermos terminais que pedem a eutanásia, pois, devido suas condições de saúde, a vida é insuportável; mudança de normas e regulações espaciais que buscam poupar recursos, mas que desrespeitam a segurança e o conforto dos habitantes. A partir desses conteúdos, conforme a T-881 (2002), a dignidade opera como qualificação das condições de vida, e não se restringe à criação de condições de vida dignas, mas estende-se à obrigação de assegurar que esse resultado será alcançado.

\subsubsection{Lesão à intangibilidade dos bens não patrimoniais - viver sem humilhação}

O objeto de proteção a intangibilidade dos bens não patrimoniais como a integridade física e a moral - viver sem humilhação -, está relacionado com o que é conhecido como o dano moral, que, segundo Fernández-Sessarego, confunde-se com o dano à pessoa" (1996, p. 58). Para compreender mais desse objeto de proteção, que é o que proporciona menor clareza nas sentencias, apoiamo-nos, portanto, no pensamento desse autor, quem expõe que um setor da doutrina da jurisprudência ao estar ciente de que, ao lado da lesão à esfera emocional ou sentimental da pessoa, apresentavam-se muitos outros ferimentos ao ser humano, e concluiu que deveria ser chamado de dano moral (p. 68).

A concepção tradicional do dano moral é o que incide no campo sentimental ou emocional da pessoa, que traz como consequência sofrimento, dor e perturbação espiritual. No entanto Fernández-Sessarego afirma que é um dano unicamente a certo aspecto do pessoal, ou seja, é uma modalidade de dano à pessoa cuja consequência é pessoal ou não patrimonial; assim, o dano moral é uma lesão que envolve basicamente o campo sentimental ou emocional da pessoa, causando um distúrbio, uma dor, um sofrimento que carece de uma base patológica, e que lesa seu corpo, sua psique, seu projeto de vida (1996, p. 58).

Este objeto de proteção, a nosso ver, e conforme os esclarecimentos de FernándezSessarego (1996) a respeito do dano moral e o dano à pessoa, o que busca é evitar a intromissão no âmbito privado do homem e manter a sua integridade e a inviolabilidade do seu espaço privado. As sentencias que têm invocado este objeto, discutiram assuntos como: detentos isentos de responsabilidade penal por demência, que solicitam que a internação psiquiátrica não perdure por tempo indeterminado; pessoas que perdem alguma parte do seu corpo, e solicitam restituir a sua fisionomia, e, consequentemente, sua integridade física e moral; crianças espancadas pelos pais ou por parentes, que buscam a proteção do Estado (T-881 de 2002). 
Mantilla e Oñate em seu livro sobre como a Corte Constitucional da Colômbia aplica as noções "dignidade" e "digno", expõem que as situações nas quais a integridade física do homem podem ser violadas, parece ser o cenário natural do discurso sobre a dignidade, como sentido original dado após a segunda guerra mundial para evitar que seja infringida dor a uma pessoa ou sofrimentos graves físicos ou psíquicos, sem ter necessidade de interpor, por exemplo, para o delito de tortura, para trabalhos degradantes ou para a escravidão (2013, p. 30).

\subsection{Esquemas argumentativos: análise desde sentencias de tutela que expõem a violação ao direito à moradia digna}

No Quadro 6.1 apresentamos todos os componentes de uma sentencia empregados como categorias de análise. Na Figura 6.1 fornecemos um esquema metodológico composto pelos elementos socioespaciais recorrentes em uma sentencia, quando o direito à moradia é violado. Esse esquema metodológico é o suporte para levantar na forma de figuras, os esquemas argumentativos, expostos no Apêndice D, Figuras D1 até D9.

\begin{tabular}{|l|l|}
\hline \multicolumn{2}{|c|}{ Componentes de uma sentencia de tutela como categorias de análise } \\
\hline $\begin{array}{l}\text { Elementos socioespaciais } \\
\text { recorrentes em uma } \\
\text { sentencia }\end{array}$ & Descrição \\
\hline Sentencia fonte & Sentencia de Tutela do ano 2014. \\
\hline Sentencia caso & $\begin{array}{l}\text { Sentencias anteriores a } 2014 \text { que são invocadas nos julgamentos desse ano. } \\
\text { Essas revisam casos semelhantes dos revisados na "sentencia fonte", razão } \\
\text { pelo qual se constituem em precedente92. }\end{array}$ \\
\hline Direito & Direitos invocados, geralmente no início da sentencia. \\
\hline Demandante* & $\begin{array}{l}\text { Pessoa natural*, empresa, instituição pública ou particular, que sofre uma } \\
\text { lesão, uma ameaça de lesão, ou uma violação de um direito. Na sentencia é } \\
\text { nomeado de "accionante", do qual se retrata uma caracterização e suas } \\
\text { condições atuais de vida. }\end{array}$ \\
\hline Demandado* & $\begin{array}{l}\text { Pessoa natural*, empresa, instituição pública ou particular, autor da lesão, } \\
\text { ameaça ou violação de um direito. }\end{array}$ \\
\hline Fato & $\begin{array}{l}\text { Narração sobre os fatos que motivaram a interposição da acción de tutela } \\
\text { perante um Juiz. Contém: direitos invocados, caracterização do demandante } \\
\text { e do demandado, situação atual do demandante, datas, lugares, circunstância } \\
\text { problemática, pretensão do demandante. }\end{array}$ \\
\hline (a) Objeto espacial em litígio & $\begin{array}{l}\text { Objeto ao que o demandante pretende acessar ou obter e sobre o qual o } \\
\text { demandado tem o controle. }\end{array}$ \\
\hline
\end{tabular}

\footnotetext{
92 Para que uma sentencia seja considerada precedente de mais uma, o Juiz deve revisar a similaridade nos fatos, a aplicação das regras e a razão para a decisão; apesar do fato de que estas características são respeitadas, os juízes podem se desviar do precedente desde que eles fundamentem a sua decisão. Assim, o precedente é o conjunto de sentencias anteriores ao caso estudado pelo juiz, por causa de sua relevância para o problema jurídico colocado. (C.C. T-245, 2014).
} 


\begin{tabular}{|c|c|}
\hline \multicolumn{2}{|c|}{ Componentes de uma sentencia de tutela como categorias de análise } \\
\hline $\begin{array}{l}\text { Elementos socioespaciais } \\
\text { recorrentes em uma } \\
\text { sentencia }\end{array}$ & Descrição \\
\hline (b) Pretensão & $\begin{array}{l}\text { A pretensão é o que o demandante solicita a respeito do objeto espacial em } \\
\text { litígio, que, por sua vez, mostra o procedimento associado com esse objeto. }\end{array}$ \\
\hline (c) Conduta & $\begin{array}{l}\text { Ação ou resposta do demandado, e que o demandante percebe, é a causa do } \\
\text { desrespeito ao direito à moradia, e, em consequência, manifesta-se como } \\
\text { lesão ou ameaça em uma entidade que poderia ser à pessoa ou ao } \\
\text { patrimônio. }\end{array}$ \\
\hline $\begin{array}{l}\text { (c) Elementos } \\
\text { socioespaciais nos que o } \\
\text { demandado escuda sua } \\
\text { conduta }\end{array}$ & $\begin{array}{l}\text { (c') Condutas escoradas nas competências e no perfil financeiro do } \\
\text { demandado; e nos processos reguladores e nas leis. } \\
\left(\mathbf{c}^{2}\right) \text { Condutas amparadas em situações espaciais sobre as quais o } \\
\text { demandado diz não ter controle. } \\
\left(\mathbf{c}^{3}\right) \text { Condutas resguardadas na atual situação de vulnerabilidade do } \\
\text { demandante. }\end{array}$ \\
\hline (d) Tipo de lesão & $\begin{array}{l}\text { Tipo de lesão gerada pela conduta do demandado. Considera-se o tipo de } \\
\text { lesão desde o âmbito jurídico e conforme as consequências que tem causado } \\
\text { no sujeito. Só em poucas sentencias, nomeiam-se os tipos de lesão, como } \\
\text { lesão, geralmente aparecem como a "situação atual do demandante". }\end{array}$ \\
\hline Tema & $\begin{array}{l}\text { Descritores da sentencia que são utilizados para identificá-la como sentencia } \\
\text { precedente. }\end{array}$ \\
\hline Palavras de busca & $\begin{array}{l}\text { Palavras de busca na base de dados da Corte Constitucional colombiana: } \\
\text { Vivienda and Digna. }\end{array}$ \\
\hline
\end{tabular}

Quadro 6.1 - Componentes de uma sentencia de tutela como categorias de análise.

Fonte: Elaboração própria.

Obs.: *Quando o demandante ou o demandado é uma pessoa natural, indagamos na sentencia por características tais como: chefe de família, integrantes dependentes do grupo familiar, idade, grupo de população vulnerável ou homogênea a qual pertence, deficiência, condição de saúde, posse do solo ou da propriedade, situação atual do demandante. 


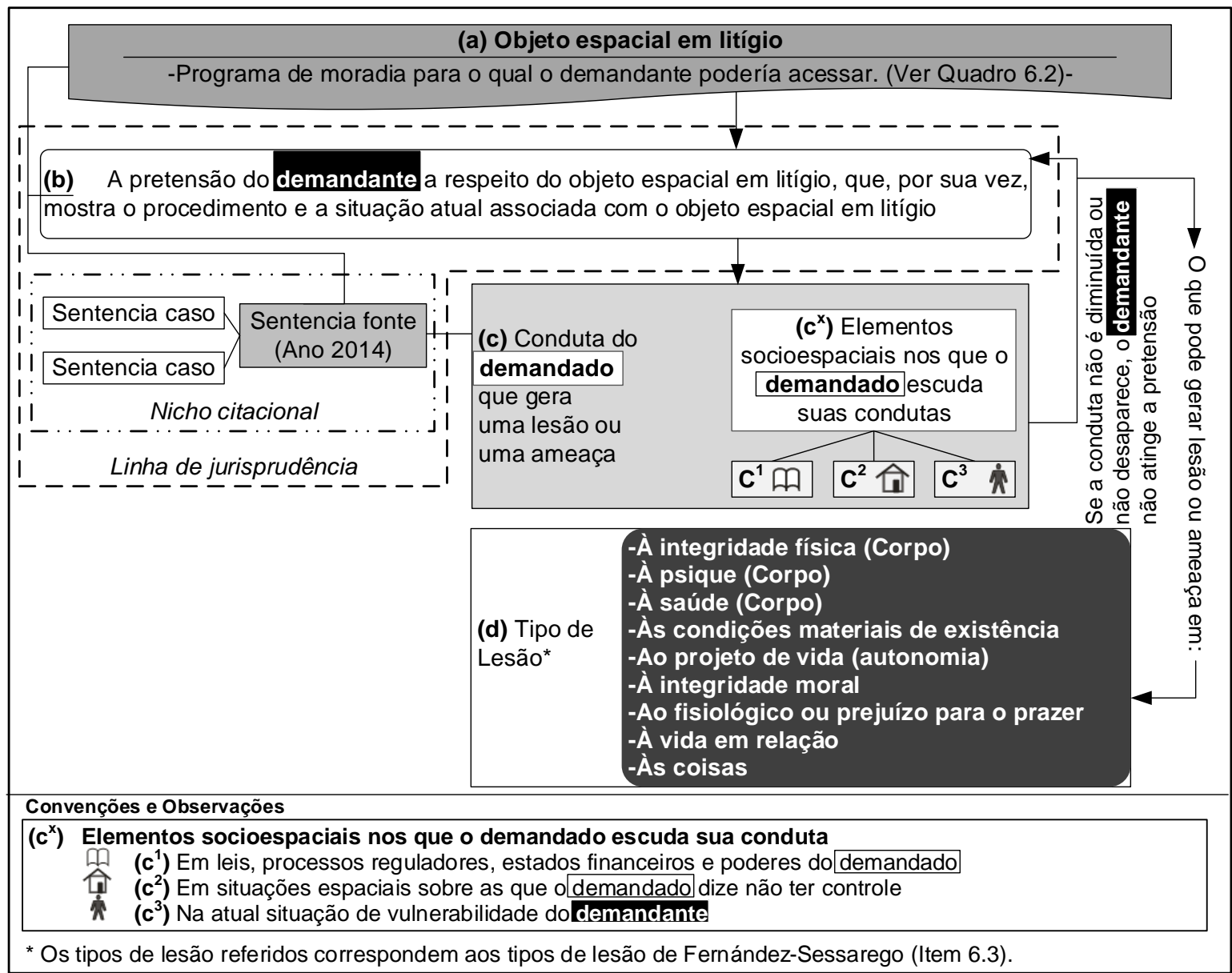

Figura 6.1 - Esquema metodológico para a construção de esquemas argumentativos, configurado pelos elementos recorrentes em uma sentencia na qual o direito à moradia é violado.

Fonte: Elaboração própria.

Obs.: Os componentes desse esquema metodológico definem-se com detalhe no Quadro 6.1.

A análise das Sentencias de Tutela entre 1992 e 2014, a partir dos esquemas argumentativos, expôs objetos espaciais em litígio tais como: [l] moradia ou lote $100 \%$ subsidiado e concedido à população vulnerável; [II] subsídio de moradia para a população em deslocamento forçado ${ }^{93}$; [III] segurança da posse por despejos; [IV] assistência humanitária para pessoas em situação de deslocamento forçado; [V] assistência humanitária para danificações por desastres associados à temporada de inverno ${ }^{94}$; [VI] crédito hipotecário; [VII] provisão de abastecimento de água potável e

93 O subsídio do qual trata os esquemas argumentativos [I] e [II] corresponde ao Subsidio Familiar de Vivienda en Especie (SFVE), regido pela Lei 1537 de 2012 da Colômbia. É uma contribuição do Estado que é entregue de uma só vez ao beneficiário, que pode ser representada em espécie ou em dinheiro, e é destinada a pessoas com recursos econômicos limitados, para que possam ter um domicílio ou melhorar o que já tem. A Lei 1448 de 2011 - Art.123, estipula que as vítimas de deslocamento pelo conflito armado que ocorre na Colômbia, cujos domicílios foram danificados pela desapropriação, abandono, perda ou prejuízo, terão prioridade e acesso preferencial aos programas de subsídio, e as moradias serão $100 \%$ subsidiadas e entregues em propriedade.

${ }^{94} \mathrm{~A}$ assistência humanitária da que trata os esquemas argumentativos [IV] e [V] constitui um auxílio mínimo nos elementos básicos, instituído nos Principios Rectores del Desplazamiento Forzado Interno 
de rede de esgoto; [VIII] intimidade e sossego, empresa em área residencial; [IX] habitação: inviolabilidade, privacidade, livre circulação. Várias situações associadas à política habitacional da Colômbia mostraram os esquemas argumentativos: o objeto espacial em litígio corresponde a algum dos programas de habitação para a Colômbia ou a condições de habitabilidade relacionadas com a saúde do morador; as condutas dos demandados converteram-se em obstáculo na hora de aplicar a atual política de habitação na Colômbia, quando a pretensão sobre o objeto espacial em litígio não é alcançada.

Os programas de habitação para a Colômbia estão baseados em segmentação de público-alvo são: Programa de Vivienda Gratuita (PVG) para hogares en situación de pobreza, pobreza extrema y vulnerabilidad priorizada, cujo suporte é a Lei 1537 de $2012^{95}$ e desde a qual é introduzido o Subsidio Familiar de Vivienda en Especie (SFVE); Programa de Vivienda de Interés Prioritario para Ahorradores (VIPA), para famílias com renda abaixo de dois (2) SMMLV96 e em situação de informalidade; Programa de Cobertura Condicionada de Tasa de Interés para la adquisición de viviendas nuevas tipo VIP y VIS97 para hogares de bajos ingresos y hasta ocho (8) $S M M L V$ con acceso a crédito (FRECH); e Programa de Cobertura Condicionada de

da Organización de las Naciones Unidas (1998). A assistência humanitária para a Colômbia é de três tipos: 1) A imediata ou de urgência, que deve ser dada ao tempo do fato do deslocamento. É entregue para deslocados que estão em situação de alta vulnerabilidade e necessitam de abrigo temporário e assistência alimentar; ademais, não precisam registro ou ato administrativo nenhum. 2) A de emergência, que deverá ser entregue para superar a fase inicial de emergência e quando o deslocado ingressou ao Sistema Integral de Atención y Reparación da Colômbia, que o inclui no Registro Único de Víctimas (RUV). 3) A de transição, que é a entregue à população em situação de deslocamento, que está incluída no RUV, e que ainda não tem os elementos necessários para uma subsistência mínima; ademais, cujo deslocamento ocorreu há mais de um ano a partir da declaração de que foi deslocado, e que, sob uma análise de vulnerabilidade, possa ser provada a persistência das deficiências nos componentes de alimentação e alojamento, como consequência do deslocamento forçado. A assistência de emergência e de transição, cujos responsáveis são os prefeitos municipais, visam garantir necessidades que não podem ser adiadas, e são atingidas desde elementos básicos como: alojamento temporário, que inclui saneamento, higiene pessoal e utensílios de cozinha; auxílio em dinheiro; contratos de alojamento com particulares ou construção de habitação temporária com o mínimo exigido de habitabilidade e de segurança; assistência alimentar: auxílio monetário, bônus para alimentação, comida servida, assegurando mínimos nutricionais para todos os integrantes da família; serviços e acesso à saúde, incluindo os específicos para a saúde sexual e reprodutiva; vestuário; transporte de emergência (EL PRESIDENTE DE LA REPÚBLICA DE COLOMBIA, 2014, Art.5; 2011, Art. 108, 112); (EL CONGRESO DE COLOMBIA, 2011, Art.63, 64).

As sentencias de tutela expõem sobre a assistência humanitária que esta tem um carácter temporário, uma vez que é um apoio para que aquele que o recebe possa superar sua condição de vulnerabilidade e adquirir uma posição consolidada de auto-sustentabilidade; pelo qual não pode ser suspensa abruptamente, mas até quando se tenha garantido a estabilização socioeconômica (C.C. T-831A, 2013); (C.C. T-702, 2012); (C.C. T-025, 2004).

95 Ver (EL CONGRESO DE COLOMBIA, 2012).

${ }^{96}$ SMMLV significa Salario Mínimo Mensual Legal Vigente. O Atual salário mínimo mensal legal é de COP\$ 689.455 ou USD \$ 203 (Valor em fevereiro de 2016).

97 VIP: Vivienda de Interés Prioritario, é uma moradia social na Colômbia cujo valor máximo não pode exceder 70 SMMLV (USD\$14.223). VIS: Vivienda de Interés Social é uma moradia social cujo valor máximo é de 135 SMMLV (USD\$27.430). Valor em dólares em fevereiro de 2016. 
Tasa de Interés para la Adquisición de viviendas tipo No VIS con precio mayor a 135 $S M M L V$ para hogares de ingresos medios con acceso a crédito (PIPE) (MINISTERIO DE VIVIENDA, CIUDAD Y TERRITORIO, 2014). No Quadro 6.2 apresentamos o objeto espacial em litígio de cada esquema argumentativo e a sua relação com o tipo de programa de habitação na Colômbia para o qual o demandante poderia ter se aplicado.

\begin{tabular}{|c|c|}
\hline \multicolumn{2}{|c|}{$\begin{array}{l}\text { Objeto espacial em litígio e sua relação com o tipo de programa de habitação na Colômbia } \\
\text { para o qual o demandante poderia ter se aplicado }\end{array}$} \\
\hline Obje & $\begin{array}{l}\text { Programa de habitação na Colômbia para o qual o demandante poderia ter } \\
\text { se aplicado }\end{array}$ \\
\hline & $\begin{array}{l}\text { breza extrema y vulnerabilidad priorizada por Subsidio Familiar de Vivienda } \\
\text { Especie (SFVE). }\end{array}$ \\
\hline po & $\begin{array}{l}\text { - Programa de Vivienda Gratuita (PVG) para hogares en situación de pobreza, } \\
\text { pobreza extrema y vulnerabilidad priorizada por Subsidio Familiar de Vivienda } \\
\text { en Especie (SFVE). } \\
\text {-Programa de Vivienda de Interés Prioritario para Ahorradores (VIPA), dirigido } \\
\text { a hogares con ingresos menores a dos SMLMV y en situación de informalidad } \\
\text { laboral. }\end{array}$ \\
\hline & $\begin{array}{l}\text { ão de despejos, o demandante fica } \\
\text { ¿ra o procedimento de aplicação pa }\end{array}$ \\
\hline & 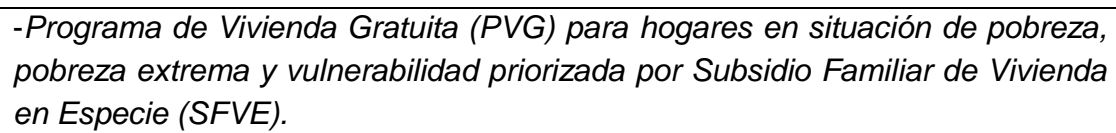 \\
\hline $\begin{array}{l}{[\mathrm{V}]} \\
\text { par } \\
\text { de } \\
\text { ten }\end{array}$ & $\begin{array}{l}\text { ograma de Vivienda Gratuita (PVG) para hogares en situación de pobreza, } \\
\text { reza extrema y vulnerabilidad priorizada por Subsidio Familiar de Vivienda }\end{array}$ \\
\hline$[\mathrm{VI}]$ & \multirow{4}{*}{$\begin{array}{l}\text { O demandante pode ter tido acesso à moradia por qualquer um dos programas } \\
\text { de governo referidos ou por outras modalidades. Os conflitos que exibem esses } \\
\text { objetos espaciais em litígio acontecem em qualquer tipo de programa de } \\
\text { habitação, e tanto em áreas urbanas, quanto rurais. } \\
\text { As sentencias não especificam o tipo de programa de habitação desde o qual o } \\
\text { demandante obteve sua moradia, e não foi possível inferir o programa de } \\
\text { habitação. }\end{array}$} \\
\hline $\begin{array}{l}{[\mathrm{VIII}} \\
\text { aba } \\
\text { potá }\end{array}$ & \\
\hline & \\
\hline $\begin{array}{l}\text { [IX] Habitação: inviolabilidade, } \\
\text { privacidade, livre circulação. }\end{array}$ & \\
\hline
\end{tabular}

Quadro 6.2 - Objeto espacial em litígio e sua relação com o tipo de programa de habitação na Colômbia para o qual o demandante poderia ter se aplicado.

Fonte: Elaboração própria.

Obs.: Poucas sentencias expõem o tipo de programa de habitação que o demandante adotou. Portanto, os programas para os quais ele se inscreveu foram inferidos a partir da pretensão do demandante e das características e das condições atuais de sua vida, as quais são descritas nas sentencias. 
Os objetos espaciais em litígio são considerados, pela jurisprudência da Colômbia, bens e serviços duráveis e, por sua vez, garantia do cumprimento do direito à moradia digna, por parte da jurisprudência e da política habitacional da Colômbia, quando são atingidos pela população alvo dos programas de habitação.

\subsubsection{O direito à moradia digna como um dever ser e sua colateralidade com outros direitos pela conduta dos demandados}

A noção do direito à moradia digna é considerada pela jurisprudência da Colômbia, como o dever ser. Os instrumentos jurídicos internacionais, invocados para provarem a violação ao direito à habitação, mostram a permeabilidade dos direitos; mas as variáveis que configuram esses instrumentos, quando descumpridas por uma violação ao direito à moradia, correspondem ao dano colateral entre os direitos.

A seguir, desagregamos a noção do direito à moradia digna da Colômbia exposta no Item 5.3.3, a qual apresentamos por frases em negrito, para evidenciar a permeabilidade como outros direitos no influxo dos elementos do Pidesc de 1991, e mais alguns outros instrumentos de direito internacional, além dos objetos de proteção da dignidade da Corte Constitucional da Colômbia; o que nos levou a desvendar os tipos de lesão, associados a essa noção, e conforme a classificação sobre o dano e lesão de Fernández-Sessarego (2002; 2002?; 1996), quando a conduta do demandado não cessa. Esses tipos de lesão, evidenciados nos esquemas argumentativos, não se encontram explícitos nas sentencias, correspondem a inferências feitas na análise, com base na descrição sobre a pretensão do demandante, seu perfil e sua situação atual, além dos direitos invocados. ${ }^{98}$

\footnotetext{
98 Vale lembrar os sete elementos do direito à Moradia Adequada do Pidesc, os Princípios da Moradia Saudável da OMS e os objetos espaciais em litígio, porquanto serão nomeados com muita frequência neste Item.

Os Sete elementos do Pidesc: (i) segurança da posse; (ii) disponibilidade de serviços, materiais, instalações e infraestrutura; (iii) economicidade; (iv) habitabilidade; (v) acessibilidade [econômica]; (vi) localização; (vii) adequação cultural. Ver (COMITÉ DE DERECHOS ECONÓMICOS, SOCIALES Y CULTURALES, 1991); (SECRETARIA DE DIREITOS HUMANOS DA PRESIDÊNCIA DA REPÚBLICA - SDH/PR, 2013). O elemento (iv) habitabilidade do Pidesc de 1991 enuncia que os Princípios da Moradia Saudável da OMS devem ser atendidos.

Os Principios da Moradia Saudável da OMS: (1) protección contra enfermedades transmisibles; (2) protección contra los traumatismos, las intoxicaciones y las enfermedades crónicas; (3) reducción al mínimo de los factores de estrés psicológicos y sociales; (4) mejora del entorno habitacional; (5) uso adecuado de la vivienda; (6) protección de poblaciones especialmente expuestas. Ver (ORGANIZACIÓN MUNDIAL DE LA SALUD, 1990).

Os objetos espaciais em litígio: [l] moradia ou lote $100 \%$ subsidiado e concedido à população vulnerável; [II] subsídio de moradia para a população em deslocamento forçado; [III] segurança da posse por despejos; [IV] assistência humanitária para pessoas em situação de deslocamento forçado; [V] assistência humanitária para danificações por desastres associados à temporada de inverno; [VI] crédito hipotecário; [VII] provisão de abastecimento de água potável e de rede de esgoto; [VIII]
} 
Es más que tener un tejado por encima de la cabeza. [...]. Donde poder pasar las noches, resguardarse de las adversidades del clima. Refere-se à função mais básica da habitação: o abrigo, e, por conseguinte, a todos os objetos espaciais em litígio.

\section{Un lugar propio y ajeno. Con protección contra el hostigamiento o la invasión irregular.}

Esse "dever ser" nas sentencias cita questões de posse, mostrando que se pode habitar um recinto tanto com um título de propriedade, quanto por outras formas de posse, em que os habitantes devem ter segurança contra despejos, expulsões, assédio ou outras interferências que facilitariam a perda do abrigo no qual o indivíduo mora. O objeto espacial em litígio [iii] segurança da posse por despejos, é a preocupação dos demandantes quando ocorrem situações tais como: os requerentes, sem saberem, compram lotes e projetos produtivos a quem não é o proprietário ${ }^{99}$; moradores que tiveram ocupando habitações ou prédios públicos sob contrato verbal há anos e em troca fizeram serviços como zelador ou faxineiro ${ }^{100}$; habitantes de áreas de alto risco, ou aqueles que perderam seus domicílios por catástrofes naturais ${ }^{101}$.

O dano à segurança da posse também ocorre quando concedidos: [I] moradia ou lote $100 \%$ subsidiado e concedido à população vulnerável, [II] subsídio de moradia para população em deslocamento forçado, [IV] assistência humanitária para as pessoas em situação de deslocamento forçado, e [V] assistência humanitária para danificações por desastres; com situações nas quais o demandante poderia perder o outorgado, porquanto o lote ou residência estão invadidos; porque as instituições que coordenam os subsídios e a assistência humanitária entregam a várias pessoas em nome de uma, ou à pessoa errada; porque a construtora não finaliza a construção dos imóveis antes de vencer o subsídio; porque o demandante aparece nos registros como proprietário em outro lugar de adjudicação do subsídio, e desde o qual tem sido deslocado pela violência e não pode retornar ${ }^{102}$. Em outro caso se relata procedimentos associados para a titulação de resguardos indígenas, no qual pela dilatação do processo por anos, geram-se situações como ameaças de agentes fora da lei e ocupação das terras de indígenas ${ }^{103}$.

intimidade e sossego, empresa em área residencial; [IX] habitação: inviolabilidade, privacidade, livre circulação.

${ }^{99}$ Ocorrência nas sentencias (C.C. T-781, 2014); (C.C. T-833, 2014).

100 Ocorrência na sentencia (C.C. T-625, 2014).

101 Ocorrências nas sentencias (C.C. T-045, 2014); (C.C. T-198, 2014); (C.C. T-254, 2014); (C.C. T825, 2014).

102 Ocorrências nas sentencias (C.C. T-019, 2014); (C.C. T-049, 2014); (C.C. T-099, 2014); (C.C. T721, 2014); (C.C. T-938A, 2014).

103 Ocorrência na sentencia (C.C. T-379, 2014). 
Nas situações referidas, nas quais os demandantes são nomeados como ocupantes ilegais, ou não Ihes é concedido auxílio para acesso ao domicílio, o tipo de lesão refere-se ao patrimônio do requerente. Porém também pode ocorrer a lesão à integridade física, quando ocorre um iminente deslocamento, o que vai gerar perda de seus abrigos. Quando a pretensão sobre esses objetos espaciais em litígio referidos apresenta obstáculos para o seu acesso, as sentencias argumentam a violação ao direito à moradia em instrumentos de direito internacional tais como: O Pidesc de 1991 com seu elemento (i) sobre segurança da posse, para as situações de deslocamentos; a Observação $\mathrm{N}^{\circ} 7$ sobre despejos forçados do Pidesc de 1997, quando discutidas questões associadas com a violação dos direitos das pessoas em situação de deslocamento forçado; os Princípios Pinheiro ou Princípios Orientadores dos Deslocamentos Forçados de 2005, para assuntos de relocalização, restituição da moradia e de terras abandonadas ou ocupadas por outros, no âmbito do conflito armado interno na Colômbia, que gera deslocamento forçado.

\section{Con prestación eficiente y planificada de los servicios públicos domiciliarios y servicios públicos asistenciales. [...]. Con condiciones adecuadas que no pongan en peligro la vida y la integridad física de sus ocupantes.}

Alude a condições espaciais expostas nos elementos do Pidesc (ii), (iv), (vi), tais como a disponibilidade de serviços básicos como água potável, saneamento básico, energia; materiais, estrutura e localização da habitação que não ponha em risco a saúde ou a integridade física dos habitantes. Fatores que, por sua vez, coadjuvam contra a exposição de agentes e vetores de doenças transmissíveis; qualidades no espaço para o bom ar no interior; com que a habitação tenha suficiente espaço habitável, bem ventilado e iluminado, decentemente, mobilado, com um grau razoável de privacidade e de conforto.

A Observação N¹5 de 2002 do Pidesc, sobre o direito à água, é o suporte para discutir a violação à habit'ação pela ausência ou má adequação da rede de água, pela sua qualidade, pelo estipêndio desmesurado, coleta indiscriminada ou pela sua contaminação, o qual abrangeria deficiências na: [VII] provisão de abastecimento de água potável e de rede de esgoto; [VIII] na intimidade e sossego em área residencial. Para o objeto espacial em litígio [VII] sobre a provisão de agua potável, as sentencias invocam o direito à água e o delimitam como a garantia de ter um serviço público do abastecimento de água que a fornece para consumo humano em termos de disponibilidade, qualidade, acessibilidade e não-discriminação (NACIONES UNIDAS, 2002); além do acesso a informação relevante sobre questões da água; clareza sobre as tarifas para o fornecimento pelas empresas; não ganho desproporcionado ou discriminatório em seu preço; adoção de medidas para impedir terceiros de contaminarem impropriamente e explorarem recursos de água ou sua extração desigual; quantidade de água disponível para projetos produtivos. Esses critérios 
sobre o fornecimento da água se informam na T-971 (2014). ${ }^{104}$.

A perturbação do ambiente pelo ruído, má cheiro, poluição, derramamento do esgoto e da água de chuva, ou por vetores de doenças em áreas residenciais, correspondem aos princípios 1, 2 e $\mathbf{3}$ da Moradia Saudável da OMS. O acatamento desses princípios vai possibilitar reduzir as lesões, envenenamentos, exposição à temperatura inadequada, entre outros fatores; para diminuir a possibilidade de tipos de lesões à saúde, à integridade física e às condições de existência, ou seja, o dano para a pessoa.

\section{Adecuación de las viviendas según la discapacidad.}

A jurisprudência abrange com esta frase às condições espaciais que atendam às necessidades específicas dos moradores, para que possam desenvolver seu projeto de vida, sem violar outros direitos como privacidade, intimidade, bom nome, saúde. Questão relacionada à habitabilidade do elemento iv do Pidesc, com os princípios da OMS 2, 3 e 6 sobre a proteção contra as lesões, os envenenamentos e as doenças crônicas; a redução ao mínimo dos fatores estressores psicológicos e sociais, e a respeito da proteção das populações particularmente expostas. Uma moradia não adequada a deficiências dos moradores pode ocorrer em qualquer um dos esquemas argumentativos. Encontramos casos como o de uma moradia social não oferecer condições para uma criança com deficiência motora ${ }^{105}$; a situação dos enfermos de HIV/AIDS ou com doenças crônicas, que requerem instalações físicas e de privacidade especiais ${ }^{106}$; o fato de que se é entregue um lote em propriedade coletiva a um grupo de pessoas deslocadas, para um projeto de cultivo da terra, mas sem condições de água e terras férteis ${ }^{107}$; moradias ou lotes conferidos $100 \%$ por SFVE,

\footnotetext{
104 A Constituição da Colômbia "não consagra expressamente o direito à água como um direito fundamental. No entanto, em conformidade com o conteúdo do artigo 93 Superior [da Constituição] que estipula que: 'Os tratados e convenções internacionais ratificados pelo Congresso que reconheçam os direitos humanos e que proibir sua limitação em Estados de emergência, prevalecem na ordem interna', esta garantia faz parte do catálogo de direitos fundamentais que qualquer cidadão pode invocar para solicitar sua proteção sob nosso sistema constitucional, tendo em conta que é reconhecido em diversos instrumentos internacionais de direitos humanos, [...] [ou seja] sob a figura do bloque de constitucionalidad" (C.C: T-790, 2014, tradução nossa). Em concordância com o anterior, a sentencia T-016 (2014) expõe que, na medida que a ineficiência no serviço de aqueduto e esgoto, lesa a vida das pessoas, a saúde pública ou a saúde individual, pode ser considerado um direito constitucional fundamental e como tal pode ser protegido através da acción de tutela.

Para casos nos que o abastecimento de água foi suspenso por razões como a inadimplência no pagamento de contas, irregularidade nas instalações técnicas, problemas técnicos segundo as empresas fornecedoras do serviço de aqueduto; a Corte Constitucional da Colômbia ordena nas sentencias de tutela, que deve oferecer-lhe ao demandante o mínimo básico e essencial de água potável, que é pelo menos 50 litros de água por pessoa por dia, conforme estipulado pela OMS no Primer Informe sobre el Desarrollo de los Recursos Hídricos en el Mundo (C.C. T-028, 2014); (C.C. T163, 2014).

105 Ocorrência na sentencia (C.C. T-270, 2014).

106 Ocorrência nas sentencias (C.C. T-245, 2014); (C.C. T-398, 2014).

107 Ocorrência na sentencia (C.C. T-971, 2014).
} 
mas localizados em uma área perigosa, razão pela qual, a doença mental de alguns deles - resultado de anteriores deslocações forçadas violentas - é agravada pela situação de violência do lugar, além de temerem a suas vidas ${ }^{108}$. Todas situações que, em caso de não ser atingida a pretensão, a lesão poderia ser sofrida na pessoa.

\section{Un espacio elemental de privacidad, sin una intromisión indebida en el espacio privado, o interferencia ilegal o arbitraria. Con condiciones adecuadas que no pongan en peligro la vida y la integridad física de sus ocupantes.}

No objeto espacial em litígio $[X]$ habitação: inviolabilidade, privacidade, livre circulação; o Tribunal da Colômbia conecta o livre trânsito com a dignidade na T-342 (2014), ao expor que o fechamento de uma passagem forçada ${ }^{109}$, por parte do dono do solo, obriga os demandantes a pegarem posições indignas quando eles têm que ir sob os cercados para chegar à estrada principal, bem como a consequente supressão da conexão com os serviços sociais e urbanos e o lugar de emprego.

Os objetos espaciais em litígio: [VII] provisão de abastecimento de água potável e de rede de esgoto; [VIII] intimidade e sossego, empresa em área residencial; [IX] habitação: inviolabilidade, privacidade, livre circulação; mostram nas suas sentencias que, se for violado o direito à privacidade e a intimidade, é uma violação ao direito à habitação. Considera-se nas sentencias, uma interferência "arbitrária" na privacidade, na intimidade e no sossego, a emanação de odores fétidos e a penetração de água com material podre ou em decomposição ${ }^{110}$; o barulho incômodo e evitável ${ }^{111}$; a perturbação por ondas eletromagnéticas ${ }^{112}$; a poluição do ambiente residencial ${ }^{113}$; 0 ingresso em domicilio alheio sem mandado judicial ${ }^{114}$. Situações que poderiam gerar uma lesão à integridade física e em certas ocasiões, mental. No entanto, no que diz

108 Ocorrência nas sentencias (C.C. T-244, 2014); (C.C. T-322, 2014); (C.C. T-583, 2014).

$109 \mathrm{Na}$ Colômbia, segundo o Código Civil, a servidumbre de tránsito (em espanhol) ocorre se um imóvel é desprovido de toda a comunicação com a rua pública, por interposição de outros imóveis. O dono do prédio que não tem comunicação com a via pública terá o direito de impor aos outros a servidumbre de tránsito, na medida em que sua livre passagem é necessária para o uso e o benefício das suas próprias instalações, pagando o valor do terreno necessário para a servidão (Art.905); se as partes não estão em acordo, será regulado por avaliadores tanto o montante da indenização, quanto o exercício da servidão (Art.905, 906) (BELLO, ANDRÉS, 1857).

Para o Brasil, a passagem forçada é quando "o dono do prédio que não tiver acesso à via pública, nascente ou porto, pode, mediante pagamento de indenização cabal, constranger o vizinho a lhe dar passagem, cujo rumo será judicialmente fixado, se necessário" (Art. 1.285); o vizinho está obrigado por lei a dar passagem. Enquanto a servidão de trânsito "proporciona utilidade para o prédio dominante, e grava o prédio serviente, que pertence a diverso dono, e constitui-se mediante declaração expressa dos proprietários, ou por testamento, e subsequente registro no Cartório de Registro de Imóveis" (Art. 1.378) (BRASIL. CÓDIGO CIVIL, 2002).

110 Ocorrência nas sentencias (C.C. T-197, 2014); (C.C. T-749, 2014); (C.C. T-801, 2014); (C.C. T-851, 2014).

111 Ocorrência nas sentencias (C.C. T-187, 2014); (C.C. T-397, 2014); (C.C. T-672, 2014).

112 Ocorrência na sentencia (C.C. T-397, 2014).

113 Ocorrência na sentencia (C.C. T-362, 2014).

114 Ocorrência na sentencia (C.C. T-409, 2013). 
sobre o ruído, está estabelecido nas sentencias como elemento perturbador do sossego, ainda que não da saúde.

A interferência "arbitrária" no âmbito espacial de uma ou várias pessoas tem a ver com o elemento iv do Pidesc sobre habitabilidade; e com os princípios 1, 2, 4 da OMS quando a não intromissão no espaço privado toma-se como proteção contra enfermidades transmissivas, contra traumatismos e intoxicações e com a melhora do entorno habitacional. As sentencias de tutela desses esquemas argumentativos baseiam-se em que a intimidade é:

A área restrita inerente a cada pessoa ou família, que só pode ser penetrada por estranhos com o consentimento do seu titular ou mediante a ordem emitida pela autoridade competente, no exercício das suas funções e de acordo com a Constituição e a lei. [O núcleo essencial do direito à intimidade] é a existência e o gozo de uma órbita reservada para cada pessoa, livre do poder de intervenção do Estado ou de uma intromissão arbitrária pela sociedade, que permite ao indivíduo o pleno desenvolvimento da sua vida pessoal, espiritual e cultural (C.C. C-881, 2014, tradução nossa).

\section{Que los grupos más vulnerables de la sociedad tengan prioridad para garantizar el acceso a los recursos necesarios para conseguir la vivienda. Que se puedan costear los gastos que exige la obtención de una vivienda digna.}

No objeto espacial em litígio [VI] crédito hipotecário, um dos seus elementos em questão é a segurança da posse no processo de obter uma casa própria, pois se recolhem as sentencias de tutela com reclamações pela perda de domicílios por causa da bolha imobiliária que ocorreu no final da década de 1990 na Colômbia. Nesse esquema argumentativo estão inseridas situações associadas, por exemplo, com à re-liquidação de crédito à habitação em prejuízo do demandante, já que ele não podia pagar a nova dívida e, como resultado, a habitação foi vendida em leilão e o demandante perdeu o domicílio ${ }^{115}$.

Esse objeto espacial em litígio [VI] está também relacionado com que "le permita al morador salvaguardar su dignidad, y sus demás derechos y libertades", pois nessas sentencias, as condutas que violam o direito à moradia, referem-se, por exemplo, a que o sistema financeiro colombiano nega a obtenção de uma apólice que é obrigatória quando se toma um crédito hipotecário, mas não será paga a apólice, desde que o demandante sofre de HIV/AIDS ou outra doença terminal, antes de tomar

115 Ocorrência na sentencia (C.C. T-398, 2014). 
o seguro ${ }^{116}$; ou por pré-existência de possíveis sintomas de alguma doença que desativa o demandante mais de $52 \%$ de sua capacidade de trabalho, após a compra do seguro ${ }^{117}$. Assim que, [VI] o crédito hipotecário não está focado na espacialidade e nas condições de habitação, mas com o elemento i, iii e o v do Pidesc sobre a segurança da posse, a economicidade e a acessibilidade econômica; e com o Princípio 6 da OMS sobre populações expostas. Situações que poderiam gerar lesões à moral, à integridade física e mental, além de ao patrimônio.

As sentencias que expõem objetos espaciais em litígio como: [l] moradia ou lote $100 \%$ subsidiado e concedido à população vulnerável; [II] subsídio de moradia para a população em deslocamento forçado; [IV] assistência humanitária para pessoas em situação de deslocamento forçado; [V] assistência humanitária para danificações por desastres associados à temporada de inverno; também têm a ver com que os grupos más vulnerables de la sociedad tengan prioridad para acceso a la vivienda; que se puedan costear los gastos que exige la obtención de una vivienda digna, y que les permita salvaguardar su dignidad, y sus demás derechos y libertades. Nesses esquemas argumentativos, a baixa capacidade econômica, a condição de saúde, a perda de um lugar para se viver, o desconhecimento sobre auxílios para acesso à moradia dos demandantes, coadjuvam ao não acesso à assistência humanitária e ao subsídio de habitação. Assunto permeado pelo princípio 6 da OMS sobre a proteção das populações particularmente expostas, com possíveis lesões à integridade física e ao patrimônio.

Que se pueda ejercitar con libertad el derecho a vivir en seguridad, paz y dignidad. Que le permita salvaguardar su dignidad, y sus demás derechos y libertades.

Alguns dos domicílios ou lotes $100 \%$ subsidiados pelo SFVE apresentam localização não segura, e assim, seus ocupantes temem a suas vidas ${ }^{118}$, o que vai em detrimento da (i) segurança da posse, da (iv) habitabilidade; da (vi) localização adequada e (vii) da adequação cultural como elementos do Pidesc de 1991. Essa frase da noção do direito à moradia digna é um dever ser pouco delimitado por elementos tangíveis. $O$ elemento tangível e fácil de ser monitorado é a segurança física; mas para a paz, a liberdade e a dignidade, não tem correspondência com variáveis residenciais; no entanto, refletem os objetos de proteção da dignidade da Corte da Colômbia. Os tipos de lesão, no parecer, referem-se ao sujeito.

116 Ocorrência na sentencia (C.C. T-245, 2014).

117 Ocorrência na sentencia (C.C. T-777, 2014).

118 Ocorrências nas sentencias (C.C. T-244, 2014); (C.C. T-322, 2014); (C.C. T-583, 2014). 
Que le permita a un individuo desarrollar en "condiciones dignas" su proyecto de vida. Lugar donde se desarrolla gran parte de la vida de las personas que la ocupan, por lo que adquiere importancia en la realización de la dignidad del ser humano.

Essa frase significa que todas as situações relatadas nos esquemas argumentativos, estão associadas com os diversos dever ser que compõem a noção do direito à moradia digna, e que não precisam estar sujeitos a satisfazer apenas um momento presente, também que não vão lesionar a pessoa e o seu patrimônio no futuro.

A Convenção sobre os Direitos da Criança de 1989, a Convenção sobre os Direitos das Pessoas com Deficiência de 2006 e a Convenção sobre a Eliminação de Todas as Formas de Discriminação Contra as Mulheres de 1979 são invocadas quando este tipo de população percebe prejudicado o seu direito à moradia quando vai ser deslocado; quando intui risco de enfermidades por perturbação do ambiente por barulho, cheiro, contaminação; quando é discriminado por sua condição de vulnerabilidade, e, assim, diminuída sua possibilidade de acesso à habitação, lote ou projeto produtivo para o cultivo da terra. Nas sentencias nas quais o demandante sofre de enfermidades terminais ou crônicas, só se invoca o Pidesc de 1991.

Uma questão interessante nas sentencias de tutela, quando os objetos espaciais em litígio eram o subsídio de moradia e a assistência humanitária, é que a violação ao direito à moradia foi discutida sob o que é chamado o princípio de subordinação e de desamparo119, para o qual a jurisprudência tem estabelecido uma definição: a subordinação faz referência à situação em que uma pessoa tem por obrigação legal a de cumprir as ordens de terceiros, como resultado de um contrato ou relação jurídica, constituindo uma relação de hierarquia entre as partes (C.C. T-362, 2014). O estado de desamparo (indefensión em espanhol), sucede quando o indivíduo foi colocado em uma situação que o torna incapaz de repelir física ou juridicamente as agressões feitas por um sujeito, as quais põem em risco os seus direitos fundamentais; em outras palavras, não tem nenhuma possibilidade jurídica ou factual de reagir para defender seus interesses (C.C. T-736, 2013).

\subsubsection{As condutas do demandado e a lesão ao demandante}

$\mathrm{Na}$ análise da descrição dos fatos a respeito das condutas, como ações ou respostas do demandado, deparamo-nos com que eles escudam-se em três tipos de elementos socioespaciais para não diminuir ou cessar essa conduta, e, em

119 Em espanhol a expressão encontrada nas sentencias foi "Principio de insubordinación y de indefensión". 
consequência, possibilitam danos para o patrimônio e para a pessoa: $\left(\mathbf{c}^{1}\right)$ condutas escoradas nas competências e no perfil financeiro do demandado; nos processos reguladores e nas leis; $\left(\mathbf{c}^{2}\right)$ condutas amparadas em situações espaciais sobre as quais os demandados dizem não ter controle; $\left(\mathbf{c}^{3}\right)$ condutas resguardadas na atual situação de vulnerabilidade do demandante.

A seguir uma análise desde cada um desses elementos socioespaciais nos que 0 demandado escuda sua conduta, além dos tipos de lesões conforme as noções de Fernández-Sessarego (2002; 2002?; 1996). Esses tipos de lesões evidenciadas, os quais não se encontram explícitos nas sentencias, correspondem a inferências feitas na análise, com suporte na narração sobre a pretensão do demandante, seu perfil e sua situação atual, os direitos invocados, e os elementos socioespaciais nos quais os demandados se escudam. $O$ alvo da análise desde cada um desses elementos socioespaciais em que os demandados escudam sua conduta, é visualizar critérios para o conteúdo prático da violação ao direito à moradia digna.

Sobre os elementos socioespaciais nos quais os demandados se escudam:

- No primeiro caso - $\mathbf{C}^{1}$, condutas escoradas nas competências e no perfil financeiro do demandado; nos processos reguladores e nas leis -, o demandado defende-se nas leis ou na falta delas; nos procedimentos, na situação financeira ou nas competências que o regem, para não reduzir ou cessar o dano ou a ameaça de lesão. No caso dos esquemas argumentativos nos quais se apresentam situações com sistemas de repositórios de dados como os que fornecem subsídio de moradia ou de assistência humanitária, mostram falhas nos dados e nos procedimentos, gerando as seguintes ações como condutas que desrespeitam o direito à moradia e lesam o patrimônio: conferidos recursos a quem não corresponde; adjudicação de domicílio ou lote a vários beneficiários; adjudicação de imóveis não legalizados e sem possibilidade de segurança da posse, porquanto estão localizados em área de alto risco por desastre, ou em áreas de violência e conflito armado; entrega de lotes para cultivo da terra como projeto produtivo coletivo, ou para construção de domicílio sem água potável ou sem condições de terra fértil; procedimento não justo e transparente de notificação e reliquidação de crédito hipotecário, o que, em consequência, leva o domicílio a ir a leilão e o demandante a perdê-la. Também encontramos situações relacionadas com contratos ou negociações entre as partes, quando, por exemplo, o demandante, com baixa renda, precisa fazer um pagamento por uma sanção urbana gerada pela construção sem licença, e o demandado não aceita a negociação da dívida.

Outros assuntos que, além do patrimônio, lesam as condições materiais de existência fazem referência: a quem foi direcionado subvenções, mas não foi adjudicado recurso nenhum; e a quem recebeu entregas parciais dilatadas em 
anos, ou os auxílios e suas prorrogações foram canceladas, seja porque o município não tinha orçamento, e porquanto está estabelecido que um deslocado com anos nessa situação, já superou sua condição de vulnerabilidade, e portanto, a instituição que regula os recursos, estipula que este demandante não precisaria de mais subvenção.

Há ainda mais outras lesões de ordem moral e patrimonial geradas por situações como ingresso em domicílio alheio sem mandado judicial; passagem forçada encerrada, a qual fecha conexão de área residencial com rua urbana; ausência de procedimentos para estabelecer níveis de risco nas áreas propensas a desastres, para a inclusão da população nos censos para o acesso à assistência humanitária.

As condutas escoradas na ausência de regulamentos ou de punições por contravenções a normas estão associadas a ocorrências como a não prestação dos serviços básicos, como quando é interrupto o serviço de água potável, sem garantir o mínimo pela OMS quando se há crianças envolvidas no caso; estouro de esgoto e de água de chuva, por obras inacabadas e por falta de manutenção; fonte de água poluída por particulares ou que se extrai em prejuízo de outros usuários; contaminação de áreas residenciais pelo barulho, odor, partículas no ar, ondas eletromagnéticas, mineração, as quais geram dano extrapessoal e dano à saúde.

- Para o segundo caso - $\mathbf{C}^{2}$, condutas amparadas em situações espaciais -, o demandado diz não ter controle sobre o assunto, e, assim, expõe que não pode fazer nada para diminuir o dano. Essas situações espaciais referidas a seguir, e que são apresentadas em relação com as entidades lesadas, abrangem espaços precários como condutas que desrespeitam o direito à moradia, e segundo os demandantes, em algumas ocasiões, a dignidade, lesando ou ameaçando o patrimônio, a moral e as condições de existência.

A lesão ao patrimônio, ao projeto de vida e às condições materiais de existência poderia ser observada quando: terrenos vendidos como lotes ou como projeto produtivo coletivo para cultivo da terra, por quem não é o proprietário; domicílios demolidos e moradores removidos, sem garantia de mais um teto no futuro, apenas porque sua posse é uma ocupação; não titulação de terras que pertencem a indígenas (resguardo em espanhol ${ }^{120}$ ), porque os procedimentos não o permitem;

120 O resguardo indígena é considerado uma propriedade coletiva de comunidades indígenas, inalienável, imprescritível e irrevogável. O resguardo é uma instituição legal e sociopolítica de caráter especial, formado por uma ou mais comunidades indígenas, que possuem seu território com um título coletivo que desfruta das garantias da propriedade privada; regido por uma organização autônoma sob a jurisdição indígena com seu próprio sistema de regulação, com diretrizes e tradições culturais próprias (MINAGRICULTURA, 1995). 
moradias ou lotes próprios que não podem ser habitados porque outros os invadiram; terrenos adjudicados por subsídio, por assistência humanitária ou vendidos como legalizados, mesmo não os sendo.

O dano ao patrimônio, além de à saúde, às condições materiais de existência quando: moradias ou lotes conferidos por subsídio ou por assistência humanitária, e abandonados devido à violência ou ao conflito armado, o que gera problemas de segurança física para a vida daqueles que moram neles; a terra adjudicada, mas sem condições de explorá-la em termos agrícola, ou sem água; áreas residenciais prejudicadas pela atividade de mineração ou por empresas que perturbam o sossego e o ambiente saudável; habitação com condições precárias, como umidade, risco de ruína, sem os serviços de água potável ou esgoto, alagada, com espaço inadequado ou insuficiente para os moradores.

- No caso $\mathbf{C}^{3}$ - condutas resguardadas na atual situação de vulnerabilidade do demandante -. À primeira vista, a conduta do demandado pode ser observada no espaço como elementos tangíveis e nos quais ele escuda sua resposta ou ação (como no caso $\mathbf{C}^{2}$ ). Com uma leitura mais incisiva destas sentencias, encontramos que o demandado escuda essas condutas espaciais na vulnerabilidade do demandante, quando, por exemplo, expressa que se o requerente não fosse criança, idoso, com deficiência física ou mental, doente crônico ou terminal, população minoritária, pobre, debilitado, deslocado, nada destas ações espaciais o teria lesado. Neste caso $\mathbf{C}^{3}$, a maior parte das sentencias expõem um detrimento à dignidade do demandante, assim como uma lesão psicossomática, à moral, na saúde, nas condições materiais de existência, pois sua qualidade de vida se ressente com as condutas.

As ações que os demandantes expõem como condutas que lesam a si são: áreas residenciais com equipamentos que refletem ondas eletromagnéticas, prejudicando a saúde e o sossego; áreas contaminadas por atividades de mineração, pelo esvaziamento de esgoto, ou por água não potável que alteram a saúde; domicílios não providos do necessário para pessoas com deficiência física ou mental; procedimentos para acesso à moradia e aos serviços básicos que excluem aos doentes crônicos e mentais; estoque de terras para habitação social e de moradia para pessoas de baixa renda e outros grupos minoritários, localizadas em zonas de conflito, ou sem serviços básicos.

Além das lesões anteriores, também há lesão ao patrimônio quando há conflitos relacionados aos termos de crédito hipotecário, em que o demandado faz a negativa de pagamento de apólices, argumentando em sua ação que ao doente terminal ou crônico, devido à possibilidade de fenecimento deste, não deve ser paga a apólice ou não tem direito de comprar uma dessas; ou na situação quando 
a re-liquidação de créditos não são transparentes, mas em detrimento do demandante, em que a resposta é que o requerente não compreendia as regulações e, por isso, perdeu sua moradia.

\subsection{Elementos socioespaciais no direito à moradia digna. Síntese}

A construção de esquemas argumentativos desde sentencias da Corte Constitucional da Colômbia é uma ferramenta metodológica para exibir contextos nos quais os direitos são desrespeitados. Os esquemas argumentativos resultantes mostraram espaços residenciais precários e que excluíam à população debilitada, sendo os componentes desses esquemas argumentativos, elementos socioespaciais recorrentes quando violado o direito à moradia, é considerado um padrão jurídicoespacial que fornece as sentencias: (a) o objeto espacial em litígio, (b) a pretensão do demandante, (c) a conduta do demandado; (d) o tipo de lesão gerado pela conduta; além de três tipos de elementos socioespaciais nos que os demandados têm se escudado para não diminuir ou cessar essa conduta.

O demandado, cuja natureza pode ser agente público ou particular, pessoa ou empresa, tem controle sobre o objeto espacial em litígio e responde à demanda com respostas tais como não ser assunto da competência de sua empresa, que as regras que o regem não admitem atingir o dano ou a ameaça, ou que, por seu perfil financeiro, não tem a capacidade de solucionar ou diminuir o dano; ou seja, o demandado define os limites desde regulamentos próprios ou desde regras de outros que não interceptam a borda da parte requerente. Esta listra ou vazio, entre a borda do demandante, que ele percebe, como descumprimento do direito à moradia; e os limites dos poderes em que o demandado escuda sua conduta, é a área em que o primeiro define que seus direitos têm sido violados.

Quando o demandante argumenta que as condutas do demandado diminuem suas chances de acesso à moradia e aos serviços urbanos; também expõem que, em consequência, as condutas minam o limite da sua privacidade, seu sossego, sua saúde, sua integridade física, do devido processo legal, da igualdade, de nome bom, do mínimo vital, da reparação a vítimas por conflito armado, da autonomia das minorias, da diversidade étnica, da propriedade privada, da propriedade coletiva, do ambiente saudável, que por sua vez, são direitos invocados nas sentencias.

$\mathrm{Na}$ revisão da evolução jurídica da noção do direito à moradia da Colômbia, descobrimos que em algumas ocasiões invoca-se o desrespeito à dignidade desde três objetos de proteção que a Corte Constitucional desse país estipulou desde a sentencia T-881 (2002); motivo pelo que deparamos em que precisávamos abordar a noção jurídica de dano e lesão para compreender a vulneração a esses objetos de 
proteção da dignidade e a violação ao direito à moradia; e o fizemos com suporte no pensamento de Fernández-Sessarego. Assim, dano, refere-se a um evento, ato ou circunstância negativo causado pela incidência de uma ação prejudicial; a lesão é o resultado derivado do dano, tanto no ser humano, quanto no seu património. Assim, o dano é visto de acordo com a (i) natureza da entidade lesada; e (ii) de acordo com as consequências que o dano tem causado na entidade lesada. No patrimonial, o dano prejudica ou deprecia os bens econômicos. A lesão à pessoa é sobre o bem-estar da vítima (FERNÁNDEZ-SESSAREGO, 2002; 2002?; 1996; 1993).

A Corte Constitucional da Colômbia estabelece que a "dignidade humana", como uma entidade normativa, pode ser observada a partir da intromissão em três objetos de proteção, considerados por esse Tribunal como conteúdo material da dignidade: (i) possibilidade de projetar um plano de vida; (ii) certas condições materiais de existência; (iii) a integridade física e moral (C.C. T-881, 2002); (C.C. T-886, 2014). O alvo dessa proteção é a pessoa na sua integridade e no seu bem-estar, ainda que se possa também advertir 0 dano ao patrimônio. O desrespeito a esses objetos de proteção, quando o direito à moradia é violado, pode ser revisado nos fatos narrados nas sentencias de tutela, e abre um caminho para a reflexão sobre as condutas que violam o direito à moradia e que ao mesmo tempo poderiam ferir a integridade do homem.

$\mathrm{Na}$ narração dos fatos nas sentencias, conseguimos interpretar uma relação não explícita entre o que os objetos de proteção da dignidade do Tribunal da Colômbia buscam salvaguardar, e as condições socioespaciais envolvidas na vulneração a esses objetos de proteção. De acordo com esta consideração, foi que encontramos os tipos de lesões que poderiam ocorrer, quando algum dos objetos de proteção da dignidade é desrespeitado. A nosso ver, quando os juízes invocam nas sentencias que a dignidade não pode ser desrespeitada, é que a pessoa, -utilizando as palavras de Adorno, quando se refere à discussão do papel do homem na bioética-, não é só um caso ou uma doença, mas uma pessoa dotada de um valor inefável e que, portanto, deve ser tratada com o maior respeito e cuidado (2012, p. 38).

Em virtude da indefinição conceitual da noção da dignidade, assim como dos objetos de proteção do Tribunal da Colômbia, Bohórquez e Monsalve afirmam que hoje decorre um assunto constante a respeito dessa noção na jurisprudência: a decisão judicial; pois na verdade, não importa o nível de dificuldade de um caso, ou se existe ou não dúvida teórica sobre o âmbito de aplicação de determinados conceitos, o juiz sempre tem a obrigação absoluta de tomar uma decisão. Isto ocorre porque a jurisprudência participa em outro nível no debate teórico sobre as tensões da dignidade humana; mas o valor principal das sentencias judiciais é que através delas, implicitamente ou explicitamente, os juízes estão definindo o escopo e o significado 
de certos termos e, em particular, estão levando para o concreto, o que, em princípio, parecia irremediavelmente abstrato (2009, p. 58).

Na Figura 6.2 podemos observar um esquema em que desagregamos a noção do "direito à moradia digna", reconstruída a partir das sentencias da Corte Constitucional da Colômbia entre 1992 e 2014. Classificamos cada uma das suas frases pelos objetos de proteção da dignidade da jurisprudência da Colômbia, e mostramos sua relação com os elementos da Moradia Adequada do Pidesc de 1991, e da Moradia Saudável da OMS de 1990, apresentando a permeabilidade dos direitos. Desde essa Figura expomos que quando quaisquer das frases da noção do direito à moradia digna não são atingidos, algum ou alguns dos objetos de proteção da dignidade da Corte Constitucional da Colômbia, poderia ficar vulnerado, e em consequência, ocorrer algum dos tipos de lesão abrangido em cada um desses objetos de proteção. Essa possibilidade de vulneração está fundamentada nas sentencias por variados instrumentos de direito internacional, visto no dano colateral causado a outros direitos.

A Figura 6.3 mostra os objetos espaciais em litígio de cada um dos esquemas argumentativos, como elementos tangíveis da política habitacional, que, quando atingidos pela população, são exibidos pelos agentes que fornecem habitação e pelos juízes nas sentencias, como cumprimento do direito à moradia. $O$ cidadão que recebe a moradia subvencionada, ou que observa melhoria nas carências espaciais que ele demandou, por conta de uma decisão de um juiz em uma sentencia, percebe que por essas ações está sendo garantido seu direito à moradia digna. No Apêndice $D$, expomos os Esquemas Argumentativos. 


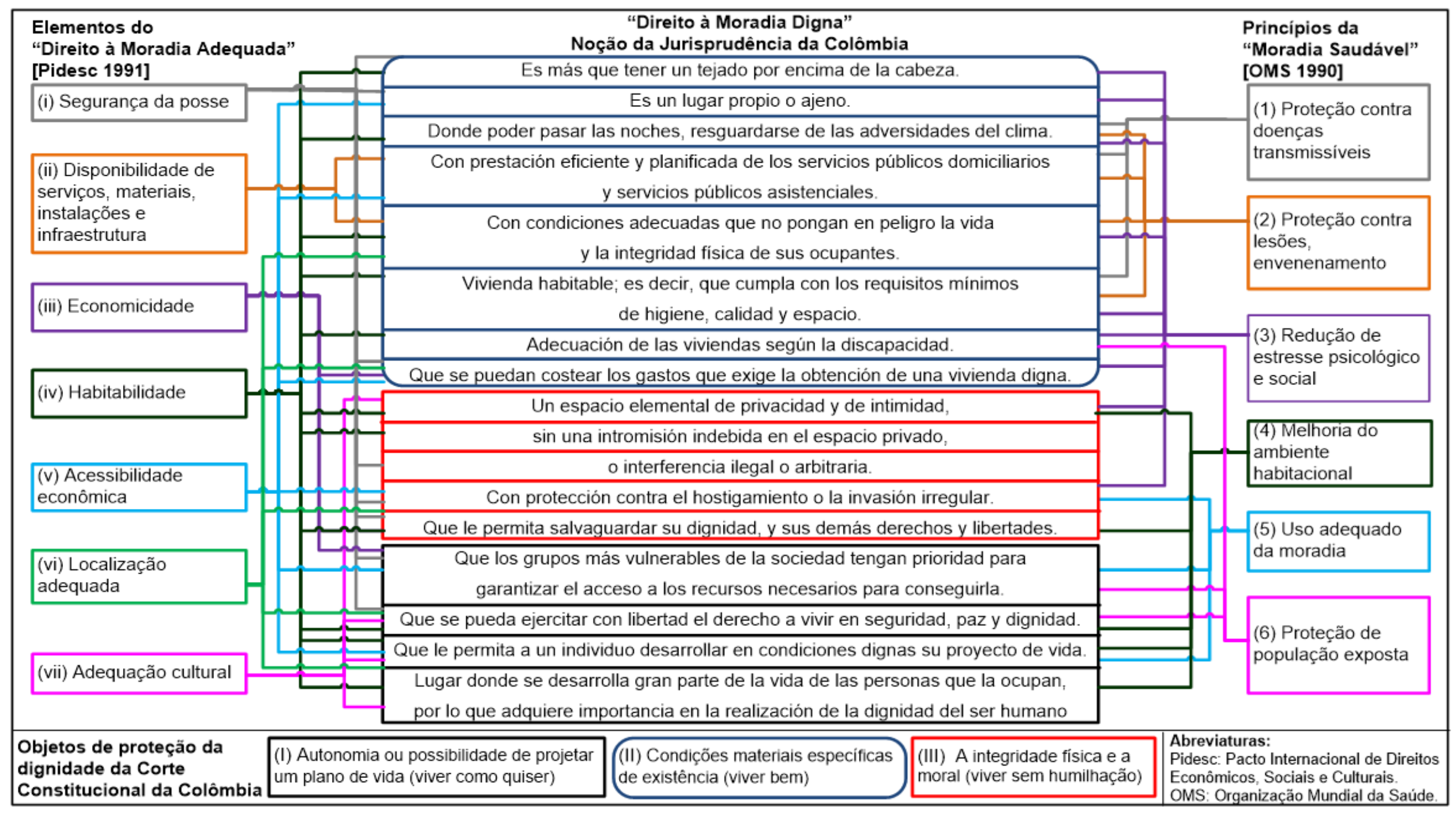

Figura 6.2 - Desagregação da noção "Direito à Moradia Digna" da jurisprudência da Colômbia, classificada pelos objetos de proteção da dignidade da sua Corte Constitucional; e a permeabilidade da noção do direito à moradia digna com os elementos da "Moradia Adequada" do Pidesc de 1991 e com os princípios da "Moradia Saudável" da OMS de 1990.

Fonte: Elaboração própria. 


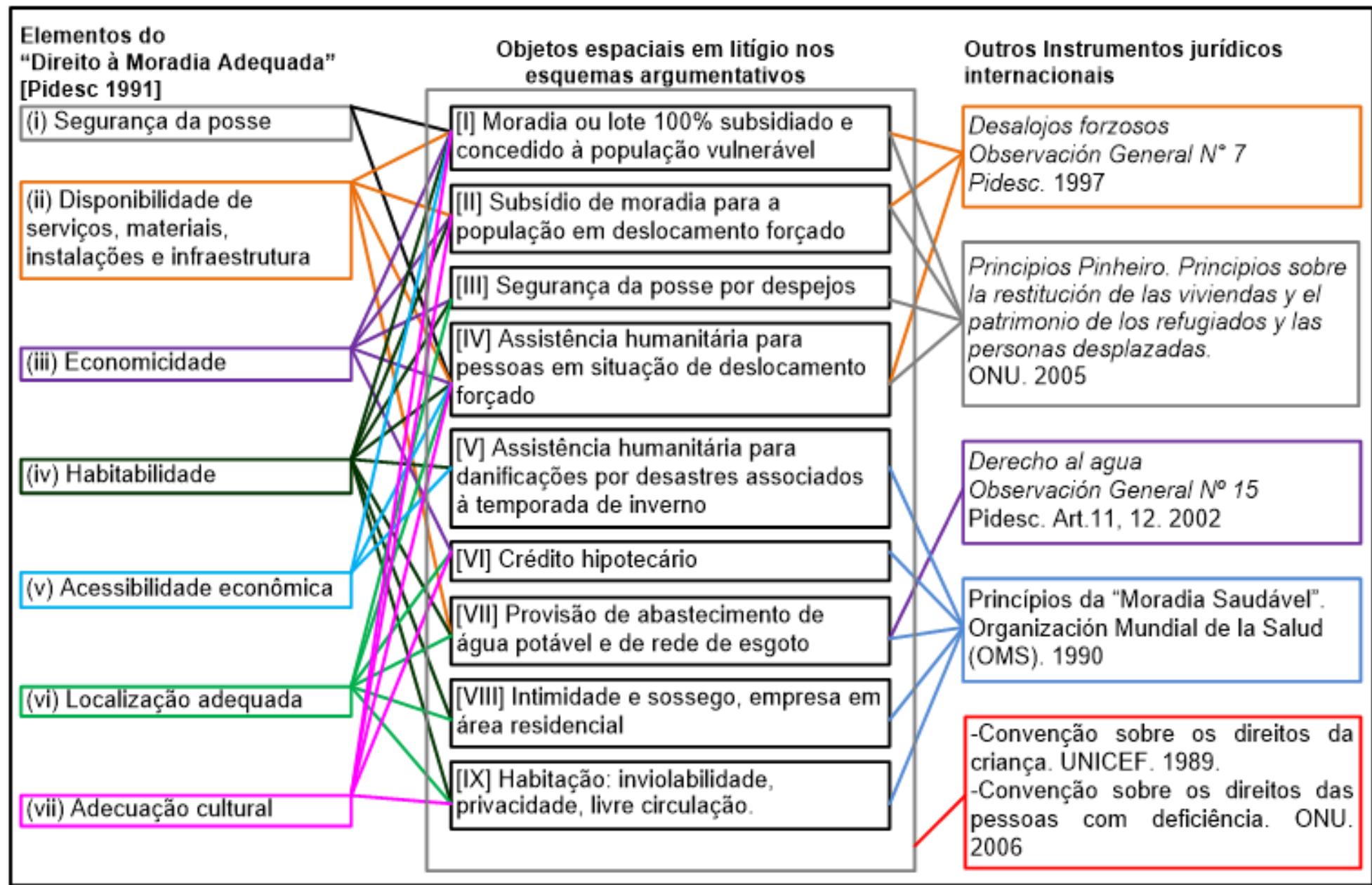

Figura 6.3 - Objetos espaciais em litígio nos esquemas argumentativos e sua permeabilidade com os instrumentos jurídicos de direito internacional, invocados nas sentencias da Corte Constitucional da Colômbia.

Fonte: Elaboração própria. 


\section{Capítulo 7}

\section{A DIGNIDADE HUMANA NA EXPERIÊNCIA ESPACIAL COMO ATRIBUTO DA MORADIA ADEQUADA}

\subsection{Introdução}

A análise de sentencias, a construção de esquemas argumentativos, a revisão da gênese, evolução e a noção do direito à moradia digna para a Colômbia; a sua permeabilidade e colateralidade com outros instrumentos jurídicos de direito internacional; a invocação do respeito à dignidade nas sentencias, que, às vezes, desrespeitada quando violado o direito à moradia; o confronto desses temas com a noção do direito à moradia adequada do Pidesc de 1991, e com o que é a moradia adequada para os países da América Latina, permitiu elucidar que a moradia digna vai mais além do padrão de moradia adequada, e que a percepção do juiz e do cidadão, a respeito da habitação digna, tem relação com a integridade do homem, a qual precisa ser protegida.

Isso deixou uma abertura no que diz sobre a lesão ao homem, quando violado o direito à habitação, e que está relacionado com o objetivo geral desta pesquisa de explorar a dimensão da dignidade na moradia. Desta forma, surgiram várias questões: $A$ dignidade de uma pessoa pode ser violada quando tem privação de tipo espacial? Sobre a noção de direito à moradia digna para a Colômbia, em que se expõe que, a moradia como abrigo deve salvaguardar a dignidade da pessoa, seria salvaguardada a dignidade quando o sujeito habita na moradia, ou também inclui os processos de acesso à habitação? Visibilizando um outro componente da noção em questão que se refere ao domicílio inviolável e sem intromissão no espaço privado, de qual interferência arbitrária deve-se salvaguardar a dignidade? Em quais entidades eu posso olhar o prejuízo à dignidade: no corpo, nas condições materiais de existência ou na moradia? É apenas o espaço inadequado e carente o que gera o dano, ou também as ações dos outros, quando o indivíduo está em busca de recursos espaciais como é uma moradia adequada e a busca não tem sucesso?

As perguntas foram respondidas quando seguimos as propostas de alguns autores, que expuseram que a dignidade poderia ter uma dimensão prática, razão pela qual voltamos à produção acadêmica e à jurisprudência no que diz sobre acepções à 
dignidade. Mesmo quando a referência à dignidade é a considerada como inviolável e inerente ao ser humano, e tem sido examinada em instrumentos de direito internacional; alguns autores afirmaram que é um conceito vago e impreciso, tornando problemática sua operabilidade. Há que se admitir a dificuldade de se precisar teoricamente um conteúdo para a dignidade humana. Vários autores têm desenvolvido um percurso histórico, remontando-se, inclusive à filosofia cristã. No entanto, mais alguns propuseram a sua problematização e outras acepções.

Assim, encontramos suposições sobre a dignidade, nas quais essa podia ser compreendida como uma experiência subjetiva ligada à fruição das necessidades básicas, incluindo habitação, podendo ser promovida ou vulnerada em interações com os outros e por ações de outros, e, assim, monitorada na integridade do corpo e da mente do homem. Após a revisão dessas propostas, desenvolvidas neste Capítulo, cuja fonte foram os autores acadêmicos e jurídicos que têm sido revisados desde esta pesquisa, buscou-se configurar uma relação entre a dignidade e a experiência na busca de recursos espaciais, na qual essa interação visaria a proteção da pessoa humana.

Neste Capítulo, como proposta desta tese, apresentamos uma hipotética proposição de fatores e categorias para observar a dignidade na experiência espacial, os quais poderão ser avaliados num contexto de violação ao direito à habitação, desde uma implementação empírica e num marco de uma subsequente pesquisa. O suporte para estabelecer esses primeiros apontamentos, a respeito da dignidade na experiência espacial, foi fornecido pelos autores acadêmicos e jurídicos que expuseram outras acepções à dignidade; bem como desde a análise das sentencias de tutela da Corte Constitucional da Colômbia.

Como partes deste Capítulo, definimos, na Introdução, os motivos pelos quais abordamos a questão de dignidade e as perguntas que surgiram nesta etapa da tese. Logo uma revisão sobre a dignidade como um conceito vago, para contrapor à dignidade com diversos significados, expostos por autores jurídicos e acadêmicos. A seguir, apresentamos - como proposta da tese - o termo da dignidade na experiência espacial, desde categorias de observação e entes lesados, bem como fatores que iriam proteger a dignidade desde a proteção do direito à moradia, o que iria constituir uma dimensão de dignidade na moradia.

\subsection{A dignidade humana em suas diversas acepções}

A referência mais destacada à dignidade é encontrada nos instrumentos de direito internacional, em que ela consta ser característica inerente ao ser humano. Em concordância com Mattson e Clark, a dignidade humana é considerada por diversos 
autores como um antecedente, uma consequência, um valor, um princípio, uma experiência; vista de uma perspectiva filosófica, legal, pragmática, psicológica, comportamental ou cultural; assim como algumas concepções poderiam ser usadas em termos práticos na política, ou como fundamento na busca de interesses comuns (2011, p. 305).

Mantiila e Oñate, em sua pesquisa sobre o uso que a Corte Constitucional da Colômbia faz sobre a noção "dignidade humana" em suas sentencias de tutela, expõem que esse Tribunal se refere à dignidade desde diversas questões para adicionar força emocional, sem expressar precisão nas condições do uso desta noção e, muitas vezes, explorada para apresentar uma decisão própria do juiz, no que diz respeito a determinados comportamentos, para obter mudanças de atitude nas pessoas. Em relação ao seu uso, continuam expondo esses autores, parece que depende dos pontos de vista morais e políticos dos juízes. Concluem que a dignidade nesse contexto das sentencias é uma definição persuasiva, porque, segundo eles, esse Tribunal não tem estabelecido diretrizes claras que tenham permitido um significado descritivo, e que simplesmente têm explorado seu significado (2013, p. 19, $61,63) .{ }^{121 .}$

Pyrrho, Cornelli e Garrafa têm afirmado que a dignidade humana tem se convertido em um problema como conceito, porque são frequentes os discursos em que se pressupõe um entendimento geral do que ela significa, e é problemática especialmente nas definições filosófica e bioética e em sua operacionalidade como conceito (2009, p. 66). O conceito de dignidade tem sido descrito como relativo e perigoso no seu uso, segundo Pinker (2008); com diversos significados, por Killmister (2010), Schroeder (2008), Jacobson (2007), Nordenfelt (2004); inútil, por Macklin (2003); segundo a revisão de autores de Schroeder (2012, p. 325) como arbitrário, (VAN STEENDAM et al. 2006: 788) ${ }^{122}$; elusivo (ULLRICH 2003: 17) ${ }^{123}$; sem

121 Mantilla e Oñate defendem a sua afirmação acerca de que o uso da dignidade, pela Corte Constitucional da Colômbia, é persuasivo na seguinte exposição: "Depois de estudar como o uso da palavra 'dignidade' e 'digno' tem um sentido amplo, incontrolavel, desde a Constituição de 1991, a questão é saber se isso fosse absolutamente necessário, se o sistema jurídico não incluísse outras instituições que permitissem alcançar alvos semelhantes, se antes de 1991 [data da Constituição vigente da Colômbia], a pessoa humana ficou completamente à mercê dos abusos e abandonada ao seu destino pelo Estado colombiano. [...]. Se analisarmos cuidadosamente o sistema jurídico, podemos identificar diferentes instituições que protegem a pessoa humana e evitam ser ela vítima de assédio e abuso: no direito penal, as lesões corporais, tortura, insulto, difamação; no direito civil, ordem pública, o objeto e a causa de ilícitos, o abuso do direito e da posição dominante, a boa-fé, os interesses da criança; no direito do trabalho, todas as garantias e proteções para os trabalhadores, etc. Todos estes existiam e existem independentemente da dignidade" (2013, p. 84, tradução nossa, aspas simples dos autores).

122 Van Steendam G.; Dinnyes A.; Mallet J., Roosendaal HE. Dignity. Sci Eng Ethics 12(4):731-793. 2006.

123 Ullrich D. Concurring visions: human dignity in the Canadian Charter of Rights and Freedoms and the Basic Law of the Federal Republic of Germany, in: Global Jurist Frontiers, 3(1). 2003. 
fundamento (Rachels 1990: 171) ${ }^{124} ;[$ [...], sem ponto de referência (Statman, 2000: $536)^{125 " .}$.

Um autor, entre outros, que se questiona sobre a proposta de Ruth Macklin (2003), quem tem criticado o eminente valor atribuído a essa noção em discussões sobre Bioética, segurando de que se trata de um conceito puramente retórico e supérfluo, que deve ser simplesmente abandonado e ser trocado pelo princípio de autonomia, é Roberto Andorno, quem responde a essa asseveração de Macklin. Aquele declara ser fato que, às vezes, a dignidade é usada de forma abusiva e puramente retórica, como se ela pudesse resolver sozinha todos os dilemas da bioética, ou como se fosse suficiente invocá-la para evitar o trabalho de desenvolver um argumento a favor ou contra uma determinada prática. Mas que isso não justifica considerar a ideia de dignidade como inútil ou como um mero sinônimo para a ideia de respeito ou de autonomia. Andorno continua dizendo ser verdade que a ideia de dignidade, normalmente, não traz uma solução imediata a dilemas concretos, mas trabalha através de outros princípios, tais como a manutenção do sigilo profissional, a exigência do consentimento do paciente, o cuidado de integridade física e mental do homem, a proibição de discriminação, entre outros debates (2012, p. 36, 37).

Andorno também aceita que o conceito de dignidade humana é suscetível a abusos e interpretações incorretas, mas que também é o caso dos princípios da ordem legal e moral como justiça, liberdade, autonomia, normalmente não definidos pela lei, não só pela impossibilidade de encontrar um significado claramente definido, com fundamentos que iriam satisfazer a todos, especialmente em contextos interculturais, mas também porque os legisladores estão cientes de que as definições rígidas são, na maioria dos casos, questões de difícil solução sob normas jurídicas (2009, p. 230).

Assim como a afirmação de Andorno, nem todos os debates desaprovam essa noção. Hoyos expressa que ao ser aceita a seguinte alegação sobre a poderosa ideia de a dignidade humana ser um princípio vácuo que não fornece regras substantivas ou quaisquer conclusões práticas, citando a Hoerster ${ }^{126}$ (1992, p. 91 apud HOYOS, 2005, p. 185), ela expõe que teriam que ser respondidas perguntas como: se os direitos humanos têm sentido, a sua base - dignidade humana- poderia não fazer sentido? Se a dignidade humana é uma noção vazia, também os direitos humanos e seus mecanismos de proteção estariam vazios? Para concluir que a dignidade humana não fornece uma forma única para sua expressão e dimensão prática (HOYOS, 2005, p. 185). Deste modo, apresenta uma fórmula do princípio da dignidade humana: "o

124 Rachels J. Created from animals. Oxford University Press, Oxford. 1990.

125 Statman D. Dignity, humiliation and self-respect. Philos Psychol 13(4):523-540. 2000.

126 Hoerster, Norbert. "Acerca del significado del principio de dignidad humana", en "En defensa del positivismo jurídico" (trad. Jorge M. Seña), Barcelona, Gedisa, 1992. 
respeito pelo outro desde o reconhecimento do outro", o qual fornece um sentido positivo e um negativo. O sentido positivo significa aceitar que o homem merece respeito. O negativo é um não-fazer: abster-se, não destruir, não usar, não impor; deixando clara a relação entre o respeito e o reconhecimento, como dois elementos complementares da dignidade. Deste modo, respeitar e reconhecer a dignidade de outra pessoa é reconhecer e respeitar a dignidade da sua própria corporeidade ( $p$. 191, 195, 200).

Killmister exibe uma acepção da dignidade como o "sentido aspiracional pelo outro", que pode ser alterada através de ações próprias, das ações dos outros ou das circunstâncias em que nos encontramos; existe, portanto, um aspecto da dignidade, seu lado ativo, que pode ser alterado. Ela expressa que a dignidade joga com dois papéis ao mesmo tempo: i) a capacidade inerente e universal que uma pessoa tem para defender, por si mesmo e para os outros, o princípio do respeito pelo outro, e agir em conformidade com esse princípio, sustentado no valor da vida humana; e ii) a capacidade latente de todas as pessoas, a respeito de suas ações, para promover ou violar este princípio do respeito pelos outros, resultando em uma ausência de humilhação ou em uma violação à dignidade do homem (2010).

Nordenfelt, citado por alguns dos autores mencionados no debate sobre a dignidade, e desde sua pesquisa sobre a dignidade e a velhice, chega a estabelecer a "dignidade da identidade", pela qual expressa que a dignidade é amarrada à integridade do corpo e da mente do sujeito e, em muitos casos, embora, nem sempre, também dependente da autoimagem do sujeito; e que essa dignidade pode ir e vir como resultado das interações entre seres humanos e, também, como resultado de mudanças no corpo e na mente do sujeito; assim sendo, a dignidade é considerada difícil de definir porque, em princípio, não depende de méritos subjetivos, mas sim de acontecimentos externos, de atos de outros (2004).

Beyleveld e Brownsword, citados por Albuquerque de Oliveira, desenvolveram duas acepções de dignidade: a dignidade humana como empoderamento e a dignidade humana como limite. A ideia de dignidade humana como empoderamento deita suas raízes no contexto internacional após a Segunda Guerra Mundial, pelas atrocidades nela cometidas, o que conduzira à comunidade internacional à percepção de que a dignidade humana é a raiz de todas as liberdades humanas, conferindo a toda pessoa, indistintamente, o direito de ser respeitada em sua própria dignidade e o direito às condições em que a sua dignidade pode florescer. Continua a expressar que a dignidade humana, como limite, teve seu surgimento atrelado às transformações advindas das práticas biomédicas surgidas no século XX; nessa concepção, a dignidade humana é pensada como um valor constitutivo da sociedade, por meio do 
qual o espaço de atuação da pessoa humana é restringido, Beyleveld e Brownsword $^{127}$ (2002 apud ALBUQUERQUE DE OLIVEIRA, 2007, p. 182).

Bohórquez e Aguirre têm exposto que a dignidade aparece não apenas como um direito ou um princípio reconhecido nos tratados internacionais, mas também renasce como critério de interpretação a favor dos direitos humanos num sentido mais amplo; e que o apelo ao respeito pela dignidade humana constitui, hoje, uma saída positiva para os direitos humanos (2009, p. 59). Supracitam a Lee para evidenciar que, apesar de status proeminente da dignidade no direito internacional e em um grande número de Constituições, a dignidade não possui sequer um significado específico ou uma definição consistente. Esta falta de precisão, muitas vezes leva a que os juízes façam seus próprios padrões morais em casos similares, susceptíveis de serem considerados como violações à dignidade, Lee ${ }^{128}$ (2008 apud BOHÓRQUEZ; AGUIRRE, 2009, P.42).

Dos autores que forneceram outras acepções e que se aproxima do debate, lançando outros olhares à dignidade desde uma aplicação empírica, ainda que não de interpretação teórica, foi Jacobson ${ }^{129}$. Pesquisadora que conduziu uma investigação empírica na área da saúde, sobre como a dignidade poderia ser observada no espaço e no corpo quando fosse desrespeitada, a partir de 64 entrevistas, em profundidade, com pessoas consideradas vulneráveis que viviam em condições difíceis e que estavam sempre em busca de recursos na cidade de Toronto, Canadá. Descobriu como a dignidade poderia ser observada e monitorada no corpo, e, assim, identificou duas formas de dignidade: a human dignity ou a dignidade humana que é a considerada inerente ao homem, e a social dignity ou a "dignidade social", como vamos continuar chamando a este tipo de dignidade de Jacobson. Essa dignidade social é uma qualidade que poderia ser gerada nas interações entre indivíduos, entre grupos e na sociedade; é contingente e poderia ser alterada, ganhada, ameaçada, medida; ferida pelo desrespeito mostrado em uma palavra ou por um gesto, pela indiferença ao sofrimento dos doentes e dos pobres, pela humilhação como forma de coerção (JACOBSON, 2012; 2012a; 2009; 2009a).

Jacobson também manifesta que a dignidade social está configurada por dois tipos de dignidade: a dignity-of-self e a dignity-in-relation. A primeira é uma qualidade individual de autorrespeito (self-respect) e de autoestima (self-worth); qualidades

${ }^{127}$ Beyleveld D, Brownsword R. Human dignity in bioethics and biolaw. Oxford: Oxford University Press; 2002.

${ }^{128} \mathrm{LEE}$, Man Yee Karen. Universal Human Dignity: Some Reflections in the Asian Context. Asian Journal of Comparative Law, v. 3, n. 1, p. 1, 2008.

129 Nora Jacobson, Centre for Addiction and Mental Health and Department of Psychiatry, Toronto, Canadá. Filiação institucional segundo Jacobson (2012). 
pelas quais um comportamento pode ser identificado como indigno. A dignity-inrelation refere-se à maneira como o respeito e a valorização da dignidade do outro são expressos e refletidos nos comportamentos individuais e coletivos para com os outros, e acontece nas interações sociais (2012, p. 16. 17; 2009, p. 3).

Essa dignidade social foi percebida por esta pesquisadora quando seus entrevistados falaram sobre a experiência subjetiva que é a busca de recursos na cidade a respeito de abrigo e de espaço; chamando essa interseção como dignity encounters, ou o que nós vamos continuar nomeando de "encontros de dignidade". Para as pessoas que eram pobres, doentes, vulneráveis, Jacobson continuou a expor que a violação à dignidade no âmbito urbano foi contextualizada por uma falta de privacidade, de autodeterminação e de escolha de opções, ou seja, a dificuldade de viver sem recursos; assim como o inconveniente da distância e o desperdício de tempo, o que aumentava as dificuldades de se mobilizar pelos vários lugares de uma cidade, a fim de satisfazer as necessidades básicas. Também observou que a busca de recursos na cidade, constantemente deixava-os em situações em que a dignidade ficava comprometida.

Nos encontros de dignidade, Jacobson procurou provas da violação à dignidade social, desenvolvendo uma taxonomia empírica de dignidade, a qual, a nosso ver, fornece elementos importantes sobre a experiência urbana. Nessa taxonomia ela descreveu "processos sociais", como formas de ação e interação que desrespeitavam a dignidade nesses encontros, e como resultavam em prejuízos que lesavam a saúde dos entrevistados, os quais já estavam em uma condição de vulnerabilidade (JACOBSON, 2012; 2009a).

Por exemplo, desde a sua taxonomia, mostra que um encontro de dignidade poderia ter como resultado a violação à dignidade, quando uma pessoa está na posição de "vulnerabilidade": enfermo, deficiente, pobre, que precisa de ajuda, envergonhado ou confundido; e o outro em posição de "antipatia": preconceituoso, arrogante, hostil, impaciente. Ou seja, que, segundo essa pesquisadora, a violação à dignidade estaria mais predisposta a ocorrer, quando a relação entre os que estão envolvidos no processo de acesso a recursos espaciais, é de assimetria, isto é, quando um indivíduo tem mais poder, autonomia, riqueza, ou é mais forte do que o outro. Desde sua taxonomia, também expôs as consequências da violação à dignidade, como sentimentos que os seus entrevistados experimentavam: degradação, sensação de fraqueza, de vergonha, de culpa, de raiva de isolamento; ressentimento e hostilidade; sentimento de não pertencer a qualquer lugar, de insegurança; de não ter força (JACOBSON, 2012, p. 63).

Em contraste, a promoção da dignidade iria ocorrer quando um indivíduo está em posição de "confiança" -, ou seja, quando este sente que merece coisas boas; e o 
outro está na posição de "compaixão" - é suave e gentil, honesto, bem-intencionado. Nestes encontros em que acontece a promoção da dignidade, a relação entre pessoas é mais de "solidariedade", caracterizada por qualidades como empatia, reciprocidade, afinidade e confiança (JACOBSON, 2012; 2009).

Os investigadores Jacobson, Oliver e Koch sugeriram que a promoção da dignidade tem se referido a um tipo de dignity work ou atividade feita por indivíduos ou instituições, cujo objetivo visava criar, manter, defender, proteger, reivindicar sobre sua própria dignidade, ou a dos outros. Estabeleceram dois tipos de trabalho de dignidade: i) o affirmative work que tinha a ver com a promoção da dignidade humana e social, em situações em que se recusava a dignidade social; (ii) o defensive work que visava reduzir ou diminuir o impacto da violação da dignidade (2012, p. 151-158; 2009a, p. 730).

A totalidade dos autores, fornecedores de diversas acepções à dignidade, expuseram que esta tem dois elementos complementares: o respeito e o reconhecimento. Também expressaram que o homem merece ser respeitado como pessoa e reconhecido com um sujeito de direito, independentemente de suas qualidades, sua condição ou seu status; e que a dignidade pode ser alterada pelas ações de outros, ou pelas circunstâncias em que nos encontramos; há, portanto, um aspecto da dignidade, seu lado ativo que pode ser alterado. Hoyos (2005) o expressa como que reconhecer o outro não é apenas aceitar a pessoa como um fim em si mesmo, é também se abster de fazer atos que interfiram com esse reconhecimento; pensamento que apresenta semelhança com o expressado por Killmister (2010), desde seu sentido aspiracional pelo outro; e por Albuquerque de Oliveira (2007), no que corresponde à delimitação de atuação humana, agindo como um compromisso de respeitar a dignidade do outro.

Essa outra acepção à dignidade que se situa no experiencial, pois ocorre nas interações entre indivíduos, tem sido chamada de diversas formas: dignidade da identidade por Nordenfelt (2004); dignidade na sua dimensão prática desde Hoyos (2005); Andorno a define na sua dimensão objetiva e subjetiva (2009); dignidade social, por Jacobson (2012; 2009; 2009a); dignidade como sentido aspiracional pelo outro, segundo Killmister (2010); dignidade como experiência subjetiva, por Mattson e Clark (2011).

É importante esclarecer que, com referência aos autores que apresentam diversas acepções à dignidade humana, esta poderia ser entendida de três formas: i) a dignidad intrínseca que, segundo Andorno, remete para o valor que tem os humanos sob sua mera condição humana, sem ser executória qualquer qualidade adicional. É um valor que está intimamente associado ao próprio ser da pessoa e, portanto, é o mesmo para todos e não suporta graus. Neste sentido, cada ser humano, mesmo o pior dos 
criminosos, é um ser digno e, portanto, não pode, em circunstância alguma, ser submetido a tratamento degradante e desumano, tortura ou escravidão. ii) O que esse autor nomeia como a dignidad ética, e que nesta pesquisa nomeamos como a dignidade atribuída, refere-se não ao ser da pessoa, mas ao seu obrar, ou seja, que o ser humano faz-se ser mais digno quando a sua conduta é direcionada para a realização de um bem. Essa dignidade humana é fruto de uma vida virtuosa e, portanto, suporta vários graus. Assim, continua expressando Andorno que, é uma dignidade dinâmica, no sentido de que é construída por cada um, através do exercício de sua liberdade (2012, p. 72). iii) A dignidade na experiência, que faz referência às ações de outros que podem promover ou lesar a integridade do homem, e que é baseada no reconhecimento do outro e no respeito pelo outro.

Na Figura 7.1 construímos uma compilação das diversas acepções à dignidade humana, fornecidas pelos autores mencionados neste Capítulo, classificadas por: dignidade intrínseca, como a dignidade inerente ao ser humano; dignidade atribuída, como a dignidade por mérito ou a que é atribuída pelo obrar próprio; e a dignidade na experiência, que se refere àquela que emerge na interação entre os indivíduos ${ }^{130}$.

130 Filiação institucional dos autores da Figura 7.1: ANDORNO, Roberto. President of the European Society for Philosophy of Medicine and Healthcare (ESPMH). Researcher and associate professor in medical law and bioethics at the University of Zurich, Switzerland. HOYOS, Ilva Myriam. Procuradora Nacional delegada para los temas de Infancia, Adolescencia y Familia, Colombia. JACOBSON, Nora. Centre for Addiction and Mental Health and Department of Psychiatry, Toronto, Canadá. KILLMISTER, Suzy. Politics Department, School of People, Environment and Politics, Massey University, New Zealand. MATTSON, David. Biological Science Center, Northern Arizona University, United States. CLARK, Susan. School of Forestry and Environmental Studies and Institution for Social and Policy Studies, Yale University, United States. NORDENFELT, Lennart. Department of Health and Society, Linköping University, Sweden. SCHROEDER, Doris. Centre for Professional Ethics, University of Central Lancashire, United Kingdom. SULMASY, Daniel. Professor of Medicine and Ethics, Department of Medicine and Divinity School, MacLean Center for Clinical Medical Ethics, University of Chicago, United States. Filiação institucional à data de outubro de 2015. 


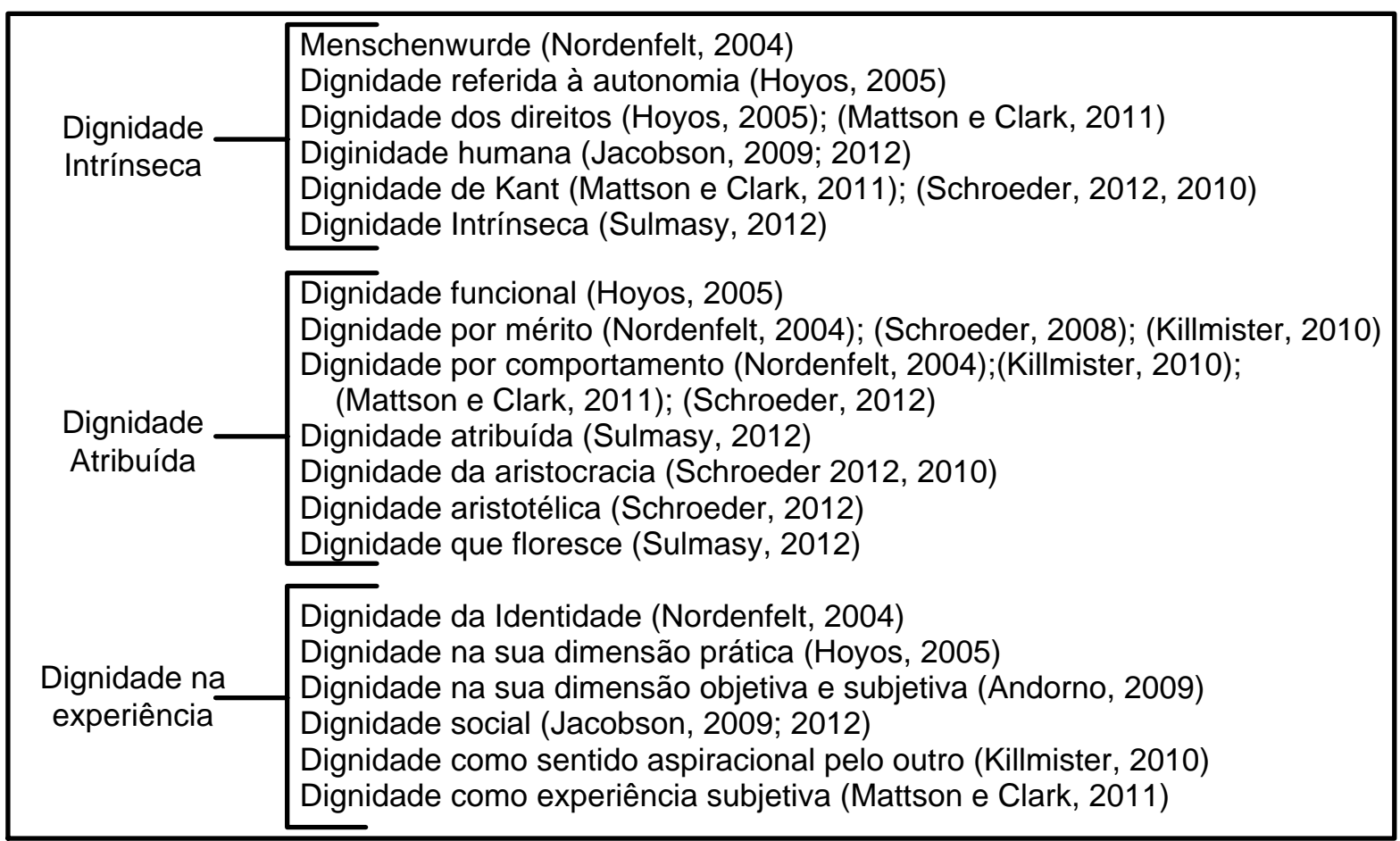

Figura 7.1 - Autores que expõem diversas acepções à dignidade, classificadas como dignidade intrínseca, dignidade atribuída e dignidade na experiência.

Fonte: Elaboração própria.

\subsection{A dignidade humana na experiência espacial}

Os autores que têm exposto diversas acepções à dignidade, e a análise das sentencias da Colômbia forneceram fatores como propriedades da dignidade na sua dimensão operacional, sendo essas propriedades da dignidade:

- Tem como princípio o respeito pelo outro no reconhecimento do outro;

- É circunstancial ou acontece por acaso;

- Não depende de méritos subjetivos do homem, e sim de eventos externos;

- É experiencial porque acontece nas interações entre indivíduos, e, assim, é subjetiva, individual e coletiva ao mesmo tempo;

- Está associada com o gozo das necessidades básicas, incluindo habitação;

- A dignidade, na sua dimensão prática, apresenta a faculdade de ser promovida ou violada;

- Poderia ser monitorada na integridade do corpo e da mente do homem.

- O sujeito ameaçado em sua dignidade pode ter pré-existências que o fazem vulnerável e, consequentemente, estar mais propenso à violação da dignidade, porém não é condição essencial estar em situação de vulnerabilidade para que a dignidade seja ameaçada. 
Para chegarmos à consideração sobre a dignidade na sua dimensão operacional, foi mais fácil examiná-la porque nos sentimos indignados; ou seja, foi mais prático medir a violação à dignidade do que a sua promoção; e aquela foi nosso foco na análise das sentencias da Corte Constitucional da Colômbia: revisar a violação.

Com relação a examinar esta situação da vulneração, seguimos a perspectiva de Jacobson, no sentido de que ela teve sua linha de trabalho na violação à dignidade; num contexto de população vulnerável por suas condições de saúde, a qual ia à cidade na busca de recursos e quando esta busca não tinha sucesso, a integridade desse homem poderia ser lesada. Esta pesquisadora também colocou em evidência, no que diz respeito a essa busca de recursos espaciais que ela nomeou como 'encontros de dignidade', que grande parte do comportamento e das atividades cotidianas na cidade vão sendo roteadas para se obter recursos do espaço, e, aqui, cita a Maslow (1975) ${ }^{131}$ com sua teoria das necessidades, para estabelecer que ter a capacidade para satisfazer necessidades, que, por sua vez, são recursos escassos, tais como: ar, água, teto, comida, higiene, segurança, serviços como educação e saúde, e serviços urbanos como transporte e informação; é o que muitos dos entrevistados referiram como uma dignified life (2012).

Ao compreender que a dignidade tem uma dimensão operacional quando apresenta as propriedades referidas, são nestas que nos apoiamos nesta pesquisa para vislumbrar o que nomeamos como a dignidade na experiência espacial; enunciado de construção própria. Assim, a dignidade na experiência espacial é uma forma de compreender a dimensão da dignidade na moradia; surge em uma interação entre indivíduos quando se está na busca de recursos espaciais "adequados" como a moradia. A dignidade violada na experiência espacial é quando essa busca de recursos espaciais não é bem-sucedida e o sujeito percebe que sua integridade física e/ou mental está sendo lesada.

\subsubsection{A dignidade humana na experiência espacial: fatores de observação e entidades lesadas}

A revisão das sentencias, visando a da lesão à integridade do homem, permitiu observar que quando ocorre a violação à dignidade, em encontros entre 0 demandante e o demandado, estes dois atores estavam em uma posição que Jacobson tem nomeado como de vulnerabilidade e de antipatia respectivamente; isto é, em uma relação de assimetria (2012). No âmbito da jurisprudência, essa relação de assimetria tem sido designada como um estado de subordinação e de desamparo.

131 MASLOW, A. Motivación y personalidad. Barcelona: Sagitario, 1975. 
Subordinação é porque há um contrato ou uma relação jurídica entre o demandante e o demandado (C.C. T-362, 2014). O estado de desamparo refere-se a que o autor da denúncia seria incapaz de defender os seus interesses e de repelir física ou juridicamente ameaças ou prejuízos feitos por outro, e que colocaria em risco os seus direitos fundamentais; também porque seria incapaz de satisfazer uma necessidade básica, por uma ação que outro faz; ou pela sua situação de fragilidade (C.C. T-736, 2013).

A vulneração à dignidade na experiência espacial poderia acontecer pela intromissão no âmbito pessoal e, às vezes, psíquico do sujeito; o que nas sentencias têm-se denominado como a intromissão na intimidade, a qual é um direito na Colômbia. $O$ núcleo essencial do direito à intimidade significa a existência e o gozo de uma órbita reservada para cada pessoa, livre do poder de intervenção do Estado ou da intromissão arbitrária pela sociedade, que vai permitir para o indivíduo o pleno desenvolvimento da sua vida pessoal, espiritual e cultural (C.C. C-881, 2014).

Conforme a jurisprudência da Colômbia, o direito à intimidade é violado pelo menos das seguintes formas: 1) quando há interferência no campo que é reservado à pessoa; é independente do encontrado no domínio da privacidade e aos efeitos de tal intrusão; cabe aqui a maneira como o agente vulnerador entra na intimidade do proprietário dos direitos, e não tanto o sucesso da operação ou do produto obtido; 2) na divulgação de fatos particulares para o público, apesar de serem certas as informações, mas sem autorização para serem divulgadas, porque pertencem à esfera privada de cada pessoa; 3) na apresentação falsa de aparentes fatos íntimos que não correspondem com a realidade (C.C. C-881, 2014); (C.C. T-696, 1996) ${ }^{132}$. Com suporte no exame das sentencias sobre quais fatos violavam o direito à intimidade, e que, como fatores, poderiam infringir a dignidade na experiência espacial, adicionamos que: 4) pela interferência de vetores externos como veículos de doenças, a poluição, o odor e o ruído; e 5) se escudar na situação atual de fraqueza do demandante para empreender uma conduta que prejudica, ou para não assumir uma conduta que violou a intimidade ou o sigilo, e, em consequência, o direito à moradia. Esses cinco fatores, poderiam alterar a saúde, a integridade física e mental e o sossego do demandante, mas viola o direito à habitação, quando ele está em busca de recursos espaciais como a moradia adequada.

${ }^{132}$ A jurisprudência da Colômbia define o espaço privado como o lugar onde a pessoa desenvolve livremente sua intimidade e sua personalidade em um "espaço reservado e inalienável". No entanto, a jurisprudência tem admitido que o desenvolvimento da privacidade e o livre exercício das liberdades individuais ocorrem não só na moradia como espaço privado por excelência, inclui o lugar de emprego, estudo: todos os espaços ou recintos em que a pessoa "normal", e legitimamente, pretende desenvolver em sua própria vida privada, separada de terceiros e sem sua presença (C.C. C-881, 2014, aspas do autor). 
As categorias de observação da dignidade na experiência espacial e os entes lesados foram construídos desde as sentencias, desde diferentes autores que debateram a habitação num marco de direito, e desde aqueles que forneceram diversas acepções para a dignidade, principalmente a partir da pesquisa de Jacobson (2012).

Jacobson (2012) fornece oito fatores, e essa pesquisadora os classifica em internos do sujeito e externos a ele, de modo a observar e a levantar questões sobre 0 fenômeno da violação à dignidade. Os internos corresponderiam a: 1) o lócus de controle, e 2) a posição da pessoa. Os externos seriam: 3) a origem do desrespeito, 4) as características do contexto, 5) a frequência e a duração da vulneração, 6) o tipo de execução, 7) os âmbitos transgredidos, e 8) a percepção. No entanto, com suporte na análise das sentencias, adicionamos mais três categorias de observação: 9) a pretensão, 10) os processos socioespaciais em que os agentes vulneradores escoram as suas condutas, e 11) o tipo de lesão desde o âmbito jurídico. $O$ total dos fatores são tomados nesta pesquisa como fatores de observação da dignidade na sua dimensão operacional, para levantar questões sobre a dignidade na experiência espacial. Todas as onze categorias podem ser classificadas segundo os elementos gerais recorrentes em uma sentencia e que configuram um padrão jurídico-espacial, descoberto pela autora desta tese, e desenvolvido no Capítulo 6, a saber: a) o contexto, b) a pretensão, c) a conduta, d) o dano e a lesão, e) a consciência da violação a um direito. A seguir, alguns apontamentos sobre os fatores de observação e sua classificação nos elementos gerais recorrentes em uma sentencia:

\section{A) 0 Contexto}

2) A posição da pessoa, vista em uma relação de assimetria (JACOBSON, 2012), ou de reconhecimento do outro. Acrescentamos que em uma relação jurídica e com suporte no que ditam as sentencias, a posição do demandante corresponde a um estado de subordinação e de desamparo. É uma categoria que corresponde ao interno do sujeito, mas que indica que um estado de vulnerabilidade não é necessariamente inerente, nem é inalterável; pelo contrário, a vulnerabilidade é contingente.

4) As características do contexto, como fator externo, envolvem os níveis em que ocorre a violação: individual, por exemplo, em uma conversa; e coletivo quando um grupo homogêneo ou minoria está sendo vulnerado (JACOBSON, 2012). Visto desde demandas judiciárias, ocorreria, por exemplo, em um contexto no qual um encontro entre duas ou mais pessoas, em que existisse um contrato de qualquer tipo, não fosse cumprido; ou leis e regulações inadimplidas ou a ausência de leis.

\section{B) A pretensão}

9) A pretensão sobre o objeto espacial em litígio, o que busca é obter mudanças nas condições espaciais; nas condições de vida; nas leis, nas regulações, nos 
processos; o que vai mostrar que tipo de dano - ao sujeito ou às coisas - poderia ser gerado, em caso de não se alcançar a pretensão.

\section{C) A conduta}

3) A origem do desrespeito como atos que podem ser: atitudes; palavras; linguagem não-verbal; comportamentos de outros; eventos ou pontos de ruptura na história do indivíduo; circunstâncias como, por exemplo, ser pobre ou estar em um estado de fragilidade (JACOBSON, 2012). Tem a ver com os elementos socioespaciais em que os demandados escudam as suas condutas (categoria 10). Esse fator abrange os interesses dos atores envolvidos.

5) A frequência e a duração da vulneração. Acrescentamos que esta categoria pode ser suporte para estabelecer questões de restituição ou de compensação de uma violação a um direito; assim, quando a lesão atinge à pessoa e não ao patrimônio, a indenização por dano subjetivo é, com muita dificuldade, avaliada em dinheiro, mas precisa-se de critérios deste tipo para sua avaliação.

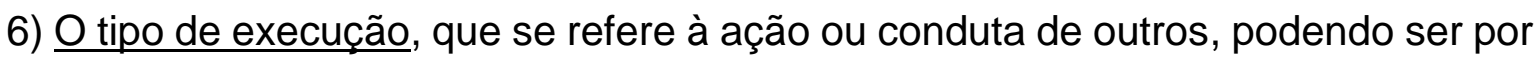
omissão, por intenção e por atribuição. As três formas poderiam se dar por uma ação deliberada do agente vulnerador. A atribuição tem a ver com a condição de fragilidade do vulnerado, na qual o agente vulnerador se apoia para lesá-lo. (JACOBSON, 2012). Acrescentamos que, ao revisar, por exemplo, o obrar de um agente público ou de um particular desde alguma das três formas de tipo execução: omissão, intenção e atribuição; poderia ser aplicado para o monitoramento de ações ou condutas vulneradoras dos direitos habitacionais, ou para a avaliação de políticas públicas sobre o não-cumprimento de fornecimento de necessidades básicas, em vista de que essas condutas não ficassem impunes e fossem consideradas violações jurídicas reais em matéria de acesso às necessidades básicas como a moradia.

10) Elementos socioespaciais nos quais o agente vulnerador escuda a sua conduta. $\mathrm{Na}$ análise da descrição dos fatos a respeito das condutas, deparamo-nos em que o demandado escudava-se em três tipos de elementos socioespaciais para não diminuir ou cessar essa conduta: $\left(\mathbf{c}^{1}\right)$ condutas escoradas nas competências, no perfil financeiro do demandado; nos processos reguladores e nas leis; $\left(\mathbf{c}^{2}\right)$ condutas amparadas em situações espaciais; $\left(\mathbf{c}^{3}\right)$ condutas resguardadas na atual situação de vulnerabilidade do demandante. Elementos desenvolvidos no Item 6.4.2.

\section{D) $O$ dano e a lesão}

7) Os âmbitos transgredidos como a estética, a higiene (JACOBSON, 2012), a privacidade, o bom nome. Podemos acrescentar que poderia também se referir aos fatores que vulnerariam o direito à intimidade, referidos no início do Item 7.3.1. 11) O tipo de lesão no âmbito do jurídico, com suporte nas noções de FernándezSessarego $(2002 ; 1996)$ e nos objetos de proteção da dignidade da Corte 
Constitucional da Colômbia, estabelecidos em sua sentencia T-881 (2002) e desenvolvidos no Capítulo 6.

\section{E) A consciência da violação a um direito}

1) O Lócus de Controle, que como uma variável da psicologia, procura explicar a percepção que a pessoa tem sobre a fonte de seu controle e sobre os eventos em que está envolvida. Este fator é interno porquanto tem a ver como o indivíduo reage ou responde, por exemplo, a comportamentos e ações externas (JACOBSON, 2012); e, assim, define, por seu próprio estado de consciência, a respeito de se foi vulnerado, e o tipo de dano e a lesão que ele considera ter sofrido.

8) A percepção. Jacobson (2012) expõe que a percepção é subjacente e controla às outras categorias; configurada por vários graus de consciência e de interpretação da vulneração, que, ao mesmo tempo, mostraria se a lesão é visível ou sutil.

Jacobson também expõe que a violação à dignidade social poderia gerar prejuízos nas seguintes entidades: o eu, a autonomia, a agência moral, o status, o cidadão, um povo ou um grupo homogêneo, e a humanidade.

- O eu. Quando a autoestima está ameaçada pela falta de respeito, indiferença, suspeita, intimidação, fraude, agressão, desprezo, privação Jacobson (2012).

- O corpo. Quando ocorrem processos sociais que contravêm a privacidade e a intimidade do homem e ameaçam as estruturas e funções que sustentam a sua vida, tais como a objetivação, a intrusão, a transgressão e a abjeção Jacobson (2012).

- A autonomia. Processos sociais como dependência ou restrição podem danificar a autonomia, definindo essa como uma "uma esfera de decisões e ações sobre as quais o sujeito tem qualquer controle ou direção" Seltser and Miller ${ }^{133}$ (1993 apud JACOBSON, 2012, p. 93).

- A agência moral. Jacobson a define como a capacidade de discernir o bem do mal e de pensar e agir de acordo com suas próprias crenças, valores, princípios e normas. É prejudicada quando há dependência, restrição, decepção e abjeção, e quando uma pessoa é pobre ou vulnerável, quando ela é forçada a fazer algo ou para aceitar os termos e condições que não são de acordo com suas crenças ou valores, apenas para obter uma ajuda, associada com os elementos que precisa para sobreviver (2012). Fernández-Sessarego afirma que o dano moral é um dano unicamente relacionado a certo aspecto do pessoal, que é uma lesão que envolve basicamente o campo sentimental ou emocional da pessoa, causando um distúrbio, uma dor, um sofrimento que carece de uma base patológica, e que lesa seu corpo,

133 Seltser, B., and Miller, D. Homeless families: The struggle for dignity. Urbana: University of Illinois Press, p. 98, 1993. 
sua psique, o seu projeto de vida (1996, p. 58). Ainda que a delimitação de Jacobson difira um pouco da delimitação de Fernández-Sessarego, consideramos que os dois autores procuram um fim comum quando buscam a proteção dessa entidade, e é evitar a intromissão no âmbito privado do homem, incluindo as suas crenças.

- O Status. É a posição social, reputação ou papel na sociedade, em que o cidadão considera-se um tipo de status. O status é prejudicado quando acontecem processos de violação à dignidade como condescendência, grosseria, desrespeito, diminuição; ou seja, quem gera a ameaça ou a lesão, percebe ao vulnerado como uma pessoa de pouca importância, ou simplesmente não reconhecido como cidadão Jacobson (2012). Essa autora (2012, p. 98) cita a Margalit ${ }^{134}$, para fazer ênfase em que o dano ao cidadão é causado por sistêmicas desigualdades na distribuição de bens e serviços, tendo em conta que os direitos do cidadão são promulgados através do acesso às necessidades tais como alimentação, habitação, emprego e cuidados de saúde; e que quando as políticas e os serviços sociais são ineficazes, porque não promovem o acesso a essas necessidades, consequentemente, negam-se os direitos associados à cidadania.

- Um povo ou grupo homogêneo. Jacobson afirma que os processos sociais de violação à dignidade podem causar danos a nível coletivo, por exemplo, para um povo que é marginalizado por se caracterizar como grupo racial, religioso, étnico, geográfico, etc. Vulnerações à dignidade que são sentidas por um indivíduo desses grupos podem ser uma injúria para todo o coletivo (2012).

- A humanidade. O prejuízo para a humanidade tem relação com a escravidão, a tortura, o sequestro, o genocídio e a pobreza extrema (JACOBSON, 2012).

As entidades: o eu, a agência moral, o status e o grupo homogêneo, encontram afinidade em seu conteúdo com o objeto de proteção da dignidade que se refere à integridade física e moral. A entidade de Jacobson - autonomia - tem analogia com o objeto de proteção da dignidade - a autonomia ou possibilidade de projetar um plano de vida -. Todas as entidades expostas por Jacobson (2012) corresponderiam a entidades que são lesadas no subjetivo e segundo as consequências da lesão, tendo como referência a classificação de Fernández-Sessarego $(2002 ; 1996)$ a respeito do dano e a lesão desde o jurídico.

$\mathrm{Na}$ revisão das sentencias, no que diz respeito à violação ao direito à moradia, apresentaram-se danos a entidades como o eu, a autonomia, a agência moral, a um grupo homogêneo. Sobre este último, nas sentencias, refere-se mais à população considerada vulnerável, como os deslocados pelo conflito armado interno na

134 Margalit, A. The decent society. Translated by N. Goldblum. Cambridge. MA: Harvard University Press. 1996. 
Colômbia, às crianças, aos homens e às mulheres chefe de grupo familiar e de baixa renda, os enfermos terminais e deficientes. Porém, nas sentencias não é percebido que o dano ao sujeito demandante que pertença a estes grupos, seja tido definido como uma injúria para todo o grupo homogêneo. A humanidade, não faria parte das entidades vulneradas, quando violado o direito à moradia, porque, segundo a delimitação que Jacobson faz desta entidade, não há condição espacial que gere tortura, sequestro, genocídio ou pobreza extrema.

Restrepo, em sua análise sobre o uso que a Corte Constitucional da Colômbia faz da 'dignidade', conclui que esse Tribunal admite que a dignidade humana pode ser lesada por: atos de exploração e objetivação, opressão; atitudes discriminatórias em relação às necessidades físicas e espirituais do homem; quando manuseado o ser humano e é obrigado a aceitar valores que ele não suporta, ou é tratado como maleável nas mãos do poder; ao submeter à pessoa para uma vida menor do que 0 indicado pela sua natureza; sujeitando-o às práticas degradantes ou desumanas (2011, p. 16).

\subsubsection{Critérios de proteção do direito à moradia que incluiria o amparo da dignidade humana na experiência espacial}

Uma violação à dignidade social exige que não só um ato, circunstância ou evento ocorra, mas que também esse ato, circunstância ou evento seja visto e interpretado como uma vulneração à dignidade do sujeito ou grupo envolvido na ação, ou por um observador individual ou coletivo (JACOBSON, 2012, p. 50). Posto isso, para colocar em evidência e publicitar a violação ao direito à moradia, devem se tornar visíveis os fatores que compõem o padrão jurídico-espacial, encontrado nas sentencias, e configurado pelos seus elementos socioespaciais recorrentes.

\section{Esses fatores são:}

- o agente vulnerador (o demandado);

- o vulnerado (o demandante);

- o objeto espacial em litígio;

- a pretensão sobre o objeto espacial em litígio;

- o processo de vulneração (o ato, a circunstância, o evento), percebido pelo vulnerado como um fato que viola a um direito;

- a conduta do agente vulnerador, como ação ou comportamento que não permite que a pretensão sobre o objeto espacial em litígio seja atingida;

- as consequências da violação ao direito à moradia, que poderiam ser observadas como dano subjetivo e como dano ao patrimônio. 
A consciência desde o vulnerado ou desde um observador externo, de que houve uma violação por parte de um agente vulnerador, é um assunto relacionado com a categoria de observação "percepção". Consequentemente, só quando a percepção de um cidadão, a respeito da violação a um direito, dirige-se para uma demanda, como é o caso da narração dos fatos em sentencias de tutela da Corte Constitucional da Colômbia, é que se publicita a violação a um direito e o discurso sobre esse direito.

A jurisprudência da Colômbia estabeleceu quatro critérios pelos quais um sujeito poderia procurar a proteção do direito à moradia digna desde acciones de tutela, e chama a atenção em que se devem verificar as causas jurídico-materiais que cercariam cada caso em particular. Os quatro critérios são: i) a presença da iminência de perigo, de tal magnitude que ponha em risco a vida, a saúde, e a integridade física ou psicológica da pessoa; ii) um sujeito de especial proteção ou em condição de vulnerabilidade e em risco; iii) deve ser comprovado o dano ao mínimo vital, entendido o mínimo vital como a satisfação das condições mínimas que cada pessoa necessita para lidar com a vida em condições de dignidade humana; iv) evidências de prejuízo à dignidade humana, expressado em degradantes situações que poderiam lesar a saúde ou a vida (C.C. T-045, 2009). No entanto, adicionamos mais dois critérios que seriam: v) uma intrusão no âmbito da intimidade da pessoa, por vetores externos ou por ações dos outros, sem o consentimento desse sujeito ou sem uma ação judicial; e vi) a lesão à integridade do sujeito.

Os três primeiros critérios poderiam ser avaliados a partir de indicadores de habitação definidos por um país, em permeabilidade e colateralidade com os elementos do direito à moradia adequada do Pidesc de 1991; e com outros instrumentos jurídicos internacionais, tais como os Princípios da Moradia Saudável da OMS; os Princípios Pinheiro sobre deslocamento forçado, e as convenções sobre crianças, mulheres, deficientes e grupos minoritários. Os três últimos critérios referem-se às violações à integridade física, psíquica e moral, para os quais não encontramos indicadores, apenas categorias e fatores evidenciados pelos autores revisados nesta pesquisa, que expuseram que a dignidade tem um âmbito experiencial e uma dimensão operacional, podendo ser ameaçada nas ações por outros.

Sobre essa dignidade, que é experiencial, apoiamo-nos na proposta empírica de Jacobson, quem construiu uma taxonomia da dignidade, a partir da que estabeleceu a violação à dignidade social. As categorias e fatores da sua taxonomia buscavam evidenciar o abuso físico e mental a pessoas vulneráveis, quando estas procuravam recursos na cidade, o que a autora nomeia, no primeiro Capítulo de seu livro de 2012 como "um universo de sofrimento humano". A respeito do abuso físico e mental, estes são vulnerações mais elevadas no direito internacional humanitário, que o direito à moradia não cobre. 
Como só temos, desde Jacobson, fatores levantados empiricamente sobre a violação à dignidade social, presumimos, a nível hipotético, os fatores de observação e as entidades lesadas referidas com anterioridade. Por outro lado, essa presunção o que permitiu foi compreender a habitabilidade no sentido amplo e não apenas a partir das variáveis e indicadores de habitação existentes. No entanto, estamos cientes de que esses fatores de observação vão requerer uma constatação empírica, em um contexto em que um cidadão vai à busca de um recurso espacial adequado como é a moradia, tanto no processo de acesso à habitação, quanto essa é habitada. Desenvolver isso, nesta pesquisa, ultrapassava os seus objetivos e os seus recursos; deste modo, fica como uma questão emergente, a ser adiantada em investigações subsequentes.

$\mathrm{Na}$ Figura 7.2 apresentamos um compêndio dos elementos de observação da dignidade na experiência espacial habitacional, desenvolvidos neste Capítulo. 


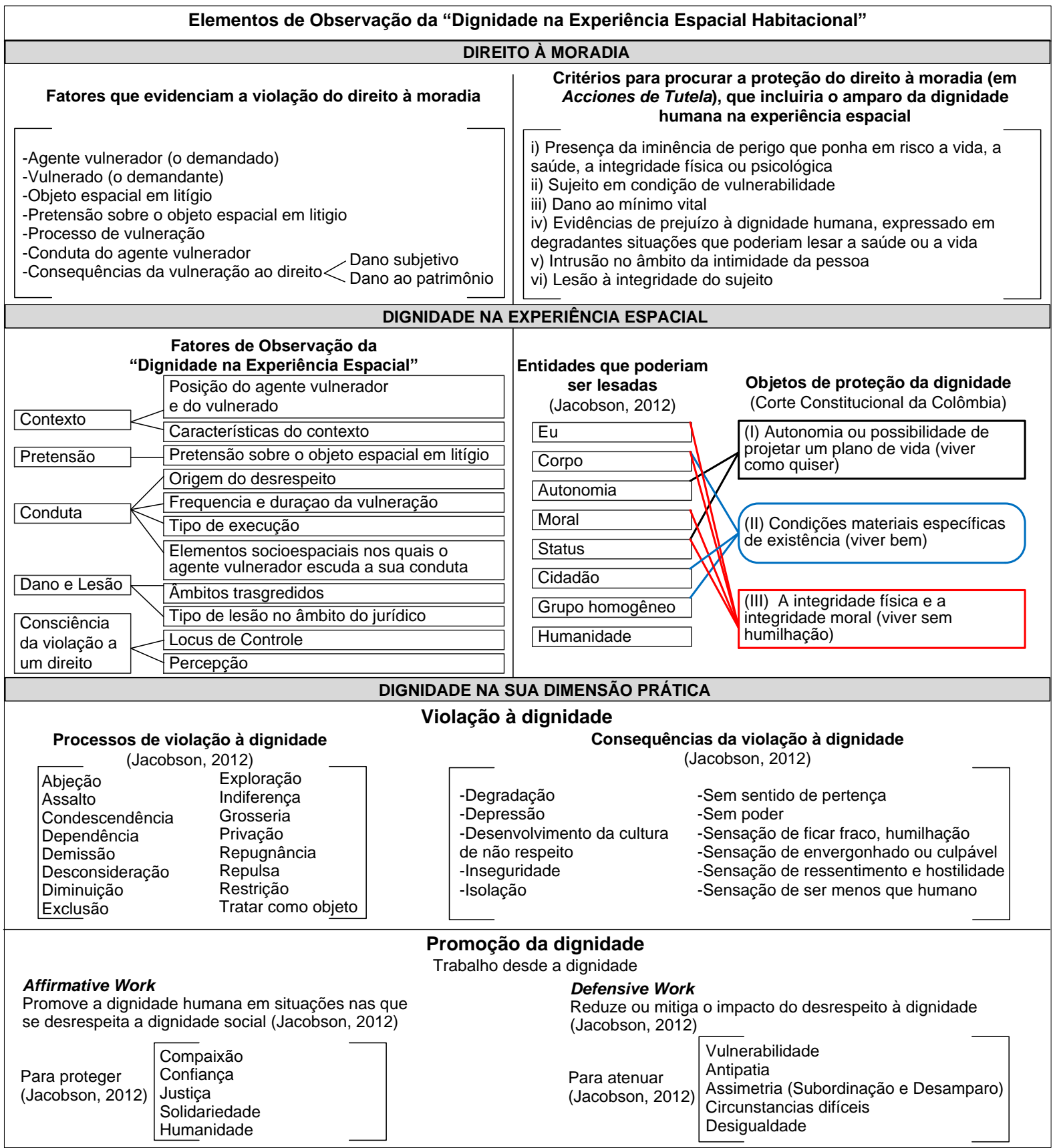

Figura 7.2 - Compêndio dos fatores de observação da dignidade na experiência espacial habitacional Fonte: Elaboração própria. 


\section{Capítulo 8}

\section{SINTESE E CONCLUSÕES}

Esta investigação se propôs, como objetivo geral, deparar por elementos socioespaciais que pudessem configurar a dimensão da dignidade na moradia - o que considerávamos, ia mais além do padrão de moradia adequada -, e tendo por referência o contexto colombiano; pois tínhamos como pressuposto que as noções em questão, ainda que complementares, e mesmo não sendo conceitualmente iguais, têm sido utilizadas indistintamente em diversos âmbitos da política urbana, tanto por agências multilaterais, quanto pelos países da América Latina, da mesma forma que no âmbito acadêmico e jurídico.

Construir a abordagem histórica e institucional acerca do conceito de "moradia adequada"; determinar fatores socioespaciais que poderiam lesar a integridade do morador que habitava em espaços inadequados; e discorrer sobre os elementos diferenciadores e complementares relacionados à moradia adequada e à moradia digna; foram os objetivos específicos como metas que permitiriam atingir o alvo geral.

Em atenção aos objetivos propostos e para responder às questões que mobilizaram esta pesquisa, analisamos a gênese, evolução e conteúdo das noções "moradia adequada" e "moradia digna" desde diversos âmbitos e agentes: em resoluções e instrumentos de direito internacional da ONU, como agente multilateral, desde 1946 ano da primeira resolução da ONU sobre moradia - até 2014. Desde o institucional, nos indicadores e variáveis de habitação aplicados à data de 2016, em 21 países da América Latina, hospedados nos seus Institutos de Estatística, cuja fonte da gênese e evolução dessas variáveis têm sido os documentos da ONU referidos. Nas Constituições vigentes desses países, as quais têm adjetivado e instaurado a noção do direito à habitação, e considerando a moradia como uma necessidade básica. $\mathrm{Na}$ produção acadêmica, a qual está compilada em grandes repositórios do mundo; sobre o debate de pensar a moradia adequada e a moradia digna.

No âmbito jurídico, como levantamento empírico, construímos, a partir de sentencias de tutela da Corte Constitucional da Colômbia (desde 1992 - ano da primeira sentencia de tutela - até 2014), esquemas argumentativos, em modo de casos nos quais o direito à moradia era vulnerado; a partir dos quais compreendemos que, 
somente quando se exibe um fato em figuras jurídicas como sentencias de tutela, e que o demandante considera ter violado o direito à moradia, é que se põe em evidência o discurso sobre a violação ou ameaça desse direito e o seu conteúdo. Deste modo, visualizamos um padrão jurídico-espacial, configurado por elementos socioespaciais recorrentes em sentencias de tutela, nas quais o direito à moradia era violado, e, em algumas situações, a dignidade.

Em fases mais tardias da pesquisa, também desvendamos, nas sentencias de tutela, que a violação ao direito à moradia era invocada, em algumas ocasiões, com o desrespeito à dignidade. Motivo pelo qual pesquisamos pela relação da dignidade com o espaço, até nos depararmos em duas fontes e perspectivas de análise: i) autores acadêmicos e jurídicos que forneceram diversas acepções à dignidade, expondo que essa poderia ser experiencial e ii) a jurisprudência da Colômbia que criou três objetos de proteção como conteúdo material da dignidade, e expostos nas sentencias.

O que descobrimos foi que na interação com outros e num contexto de busca de recursos espaciais adequados como é a moradia, a dignidade poderia ser ameaçada quando fosse percebida inserida na experiência no espaço. Essa abrangência a respeito da dignidade, ajudou a construir alguns fatores de observação sobre o que nomeamos como a dignidade na experiência espacial, como uma forma de compreender a dimensão da dignidade na moradia.

Apresentamos neste Capítulo final, portanto, o que tem sido para o âmbito multilateral, institucional, jurídico, e social mediado pelo judiciário, a moradia adequada e a moradia digna. A seguir, as conclusões sobre o abarcamento de cada uma das noções em questão, desde a dignidade na experiência espacial, e alguns temas para futuras pesquisas.

\subsection{A moradia adequada e a moradia digna segundo os diferentes agentes. Síntese}

As Nações Unidas, como agente multilateral, com seus instrumentos jurídicos de direito internacional, e suas resoluções que ditam as diretrizes mandatórias sobre assentamentos humanos para os países membros; o institucional, como os Institutos de Estatística dos países da América Latina, que alojam a metodologia e os dados sobre os indicadores da habitação, e seus diagnósticos sobre assentamentos humanos; o jurídico institucional, desde as Constituições dos países da América Latina, que elevam ao status do direito, a moradia, entre outras necessidades básicas; o acadêmico que hospeda a sua produção em grandes repositórios do mundo e debate sobre a habitação num marco de direitos; o jurídico que, nas sentencias da Corte Constitucional da Colômbia, media a percepção do morador, no que diz respeito 
à violação ao direito à habitação, além de que introduz a noção do direito à moradia digna. Todos eles delimitam, desde seus campos e interesses, a moradia adequada e a moradia digna

As Nações Unidas, como instituição fonte da origem das variáveis e indicadores de habitação para os países da América Latina, instauraram, desde a década de 1950, um standard de vida mínimo configurado pelos seguintes componentes: saúde, nutrição, moradia, condições de emprego e educação. Na década seguinte, este standard de vida tornou-se um conjunto de necessidades básicas composto por alimentação, abrigo, vestimenta, equipamentos domésticos, serviços essenciais; que só poderia ser alcançado a partir de uma remuneração adequada.

O conjunto de componentes e variáveis do standard de vida da década de 1950, que mudou no decênio seguinte para o conjunto de necessidades básicas, são na década de 2000, variáveis dos indicadores de habitação dos países da América Latina, do indicador de Hogar de Assentamentos Precários dos Objetivos de Desenvolvimento do Milênio (ODM) de 2000, e fazem parte dos elementos da Moradia Adequada do Pacto Internacional de Direitos Econômicos, Sociais e Culturais (PIDESC) de 1991. O denominador comum de todos esses períodos e indicadores é a noção de "necessidades básicas", aplicado para a maioria desses países, como Indicador de Necessidades Básicas Insatisfeitas (NBI), desde meados da década de 1970.

Em consequência, para os países da América Latina, o que constitui uma moradia adequada é: um diagnóstico a partir do Déficit Habitacional, do Indicador de Necesidades Básicas Insatisfechas (NBI), do Indicador de Moradia Adequada do Pidesc de 1991, cuja base destes indicadores é esse conjunto de necessidades básicas instaurado pelas Nacões Unidas. A moradia e os serviços básicos fazem parte desse conjunto de necessidades básicas, consideradas bens e serviços duráveis. No entanto, esses indicadores o que diagnosticam é a carência de características desses bens e serviços, que em palavras da política habitacional, referem-se às variáveis de habitação. Mas esses diagnósticos não estabelecem a capacidade das famílias para satisfazer essas carências, a qual poderia mostrar diversos graus de satisfação a respeito da moradia adequada.

A habitação, como um direito nas constituições, contém, em seu conteúdo prático, as variáveis de moradia de cada país, como o mínimo que um Estado deveria garantir e que um cidadão poderia exigir como direito habitacional. Ainda que a heterogeneidade habitacional seja tão vasta, que nem todas as deficiências pudessem refletir-se nas variáveis residenciais, o indicador de habitação detém este papel fundamental de configurar o mínimo e o objetivo do direito à moradia, para manter, na categoria de direito, as adjetivações dadas à habitação, contidas nas Cartas Políticas. 
A importância dos indicadores habitacionais radica em que é um conjunto de variáveis, que consiste no mínimo a ser garantido como moradia adequada, e o suporte objetivo e material do direito à moradia, constitucionalizado nas Cartas Políticas das nações; para que, em concordância com Pisarello, as ações e as omissões dos Estados ou de particulares, que minam 0 direito à habitação, sejam consideradas como reais violações jurídicas das necessidades habitacionais $(2003$, p. 105, 108).

O âmbito acadêmico, tal como o multilateral e o institucional, também instaura noções. Desde a produção acadêmica, elaboramos uma revisão de literatura em grandes repositórios de produção acadêmica do mundo, em documentos públicos disponíveis on-line; permitindo-nos, deste modo, descobrir vertentes sobre o tema da moradia, e, por conseguinte, a possibilidade de abordagens alternativas ao objeto de estudo desta pesquisa não previstas no início da investigação, e desde as quais se move o debate sobre a habitação: i) a política de habitação, ii) o direito à moradia, e iii) a moradia adequada para indivíduos com condições especiais de saúde física e mental.

Sobre a política de habitação não encontramos documentos pertinentes. No que diz sobre o direito à moradia, a maioria dos documentos mostraram a necessidade de observar, avaliar ou discutir o problema de acesso econômico e da habitabilidade na habitação num marco de direitos. Outro assunto foi a alusão a instrumentos jurídicos de direito internacional tais como a Dudh de 1948, a Dadh de 1948, o Protocolo de San Salvador de 1988 e o Pidesc de 1966 e de 1991, e Convenções sobre grupos minoritários, mostrando, desde essa permeabilidade dos direitos, o vínculo do direito à moradia com a dignidade. Desde a última vertente, os autores expuseram acepções à dignidade relacionadas com a moradia e a autonomia do morador nos domicílios, quando se é vulnerável por condições de saúde física ou mental. Estes autores acadêmicos, na sua maioria, têm pertencido ou pertencem ao âmbito público do político urbano, do jurídico, ou da área da saúde que trabalha com população vulnerável; mas não estabelecem definições sobre o conteúdo dos direitos habitacionais ou sobre a moradia adequada e a moradia digna, e não controvertem sobre o tema.

As resoluções e conferências mundiais da ONU estabelecem agendas em todos os âmbitos, inclusive no acadêmico, desde diretrizes e temas de pesquisa a se desenvolverem. Há liderança maior de estudos sobre habitação desde organismos multilaterais do que no âmbito acadêmico, em termos de aportes teóricos, e de criação de noções e variáveis. Estes últimos debatem sobre moradia com foco no concreto e no empírico; geralmente limitados a levantar diagnósticos, avaliar indicadores e discutir políticas de habitação, que, quando não bem-sucedidas, são tomadas como habitação não digna. No entanto, procuram que os seus discursos sobre a habitação estejam enquadrados no direito, sem definir claramente o que significa o direito à moradia. 
As figuras jurídicas tais como as sentencias, que recolhem demandas pela violação ao direito à moradia, consideramo-las como uma interseção de todos os âmbitos em estudo: a ONU como organismo multilateral, a qual forneceu variáveis universais de habitação, desde o indicador do Pidesc de 1991, bem como desde outros instrumentos de direito internacional, refletidos na noção do direito à moradia digna para a Colômbia, contida nas sentencias; os institutos de estatística dos países da América Latina, que estabeleceram variáveis residenciais que configuram o conteúdo prático do direito à moradia, adjetivado nas constituições desses países; o acadêmico e o jurídico fornecedores de posições teóricas a respeito do conteúdo dos direitos habitacionais; o cidadão que expôs nas demandas sua percepção sobre a violação dos direitos habitacionais e que foi mediada pelo juiz, e o próprio juiz que argumentou e instaurou decisões a respeito, como compreensão jurídica do direito à moradia digna violado.

A Corte Constitucional da Colômbia não produz singular conhecimento teórico sobre habitação, produz um conhecimento jurídico sobre o direito habitacional, alimentandose do existente. Autores jurídicos e acadêmicos lutam para que sejam inclusos nos indicadores de habitação, não só as variáveis quantitativas, mas também qualitativas, e cuja finalidade seja proteger a integridade do homem. Expomos que a combinação destas duas perspectivas deve alimentar o conteúdo material e objetivo do direito à habitação.

Quando nas sentencias de tutela da Corte Constitucional da Colômbia, o juiz expõe que o cidadão precisa de "espaços com condições dignas", com base na sua noção de "direito à moradia digna" e nos objetos de proteção da dignidade, ele faz referência a "condições adequadas", correspondendo às variáveis de habitabilidade, incluídas na sua noção de moradia digna. Mas quando esses critérios de habitabilidade, incorporados nessa noção, tornam-se carências à custa: i) da saúde dos moradores; (ii) da sua integridade física e mental; iii) do desenvolvimento de atividades da vida diária; iv) de suas condições materiais de existência; v) da alteração de seu projeto de vida; é quando o juiz percebe que as condições espaciais poderiam gerar situações que perturbam a dignidade na experiência espacial, e é a pessoa quem sofreria a lesão; pelo que faz referência ao direito à moradia digna. O patrimônio ou os bens do sujeito também podem ser depreciados ou desaparecerem, mas a ameaça à dignidade na experiência espacial refere-se à lesão à pessoa.

Quando o cidadão comum menciona, em diferentes instâncias da vida cotidiana, que habita uma moradia que não é digna, refere-se a essa inter-relação que o homem constrói com o espaço, e desde a qual a sua integridade poderia ser lesada. $O$ agente que fornece a habitação sob o título de "digno", o faz porque considera que atender as normas e os padrões de habitabilidade é cumprir com habitação digna e adequada; 
mas também porque ele sabe que o termo do "digno" fornece uma conotação de qualidade na qual confia para se conduzir a uma imagem de excelentes condições espaciais.

Assim, o indicador "direito à moradia adequada" foi configurado por sete elementos e institucionalizado desde o Pidesc de 1991, o qual significa ter mais do que um abrigo para se proteger do clima e dos vetores de enfermidades externas; significa também um lugar onde se tenha privacidade e espaço suficiente para o indivíduo desenvolver a sua própria vida e a sua cultura; construído com materiais duráveis e seguros; com iluminação, aquecimento e ventilação suficientes; com infraestrutura básica adequada para serviços de água, esgoto e eliminação de resíduos; com acesso aos serviços urbanos; com segurança da posse; e, tudo isso, a um custo razoável.

A moradia digna como um direito, delimitado na jurisprudência da Colômbia, definese como sendo mais do que um teto sobre sua cabeça, é um lugar próprio ou de terceiros, onde se passa a noite, guarda-se contra as adversidades do clima; com fornecimento planejado e eficiente dos serviços básicos; com condições que não ponham em perigo a vida e a integridade física dos seus ocupantes. Uma moradia habitável; ou seja, que vai acolher os requisitos mínimos de qualidade, higiene e espaço. Com adaptação dos domicílios, de acordo com deficiências dos moradores. Que se possam pagar as dívidas que exige a obtenção de uma moradia digna. Um espaço de privacidade e intimidade, sem uma intromissão indevida no espaço privado, ou interferência ilegal ou arbitrária. Que os grupos mais vulneráveis da sociedade tenham prioridade para se Ihes garantir o acesso aos recursos necessários para obter um domicilio. Mas também a proteção contra a invasão ou o assédio, e lugar que possibilite salvaguardar a dignidade do morador, e seus outros direitos e liberdades. Que o morador possa exercer livremente o direito de viver em segurança, paz e dignidade, para desenvolver seu projeto de vida em condições dignas. Um lugar onde é desenvolvida grande parte da vida das pessoas que a ocupam, motivo pelo qual se torna importante na realização da dignidade do ser humano. Essa noção vigente nas sentencias de tutela, evidencia o influxo, principalmente, do indicador de direito à moradia adequada do Pidesc de 1991, do Pidesc de 1997 sobre deslocamentos forçados, dos Princípios da Moradia Saudável da OMS e de uma invocação constante ao respeito à dignidade.

As variáveis, tanto da noção de moradia adequada, como indicador considerado universal, quanto da noção de moradia digna, de âmbito nacional; deveriam abranger a correspondência com valores mínimos, que em caso de não serem garantidos, envolvem lesões para o homem e para o patrimônio. Mas, enquanto não exista correspondência e corresponsabilidade entre indicadores, políticas e regulações sobre habitação, e nas variáveis inseridas no âmbito do direito, o mínimo na habitabilidade residencial a ser garantido, não terá resposta material. O conteúdo do 
direito à habitação deverá ter correspondência e corresponsabilidade com as variáveis estabelecidas no déficit habitacional de cada país, para se conseguir dar fundamento e publicidade à violação ao direito à moradia, para aplicá-lo desde e na política habitacional; também para garantir a discricionariedade de um direito. Caso contrário e como observamos nas sentencias, tanto a definição do direito à moradia adequada, quanto a da moradia digna não possibilitam uma perspectiva valorativa para estabelecer precedentes na sua violação, e, assim, os juízes fundamentam distintas valorações da violação ao direito habitacional, mesmo diante de fatos semelhantes. Situações, inclusive, parecidas ocorrem com os objetos de proteção da dignidade quando relacionados com fatos que ameaçam este direito.

Quando se debate em demandas jurídicas que os indicadores de habitação não são atendidos, é uma controvérsia sobre a política de habitação que desgasta essa política, desde que não se transcenda à legitimidade do conteúdo do direito à moradia.

\subsection{Moradia adequada e dignidade humana na experiência espacial habitacional num marco de direitos. Conclusões}

\section{Política habitacional}

A política de habitação na Colômbia para o ano de 2016 baseia-se na segmentação do grupo alvo, segundo a sua capacidade econômica, e está direcionada a construir um país de proprietários. Nos esquemas argumentativos, podem ser observados obstáculos na hora de implementar essa política, na forma de condutas dos demandados, as quais impedem de se obter a pretensão do demandante a respeito da habitação, dos serviços básicos e urbanos, e de seu aproveitamento com condições adequadas. No caso de acesso a domicílio com 100\% de subvenção, ou por assistência humanitária, é uma política considerada indenizatória para população muito vulnerável, de escassa renda, para deslocados pelo conflito armado na Colômbia, e para aquele que em desastres tem perdido seu domicílio.

A perda de habitação pelo deslocamento e pelos desastres é considerada, na jurisprudência da Colômbia e num marco do direito à moradia, um dano ao patrimônio, podendo ser compensado em dinheiro ou em espécie, equivalendo a um domicílio $100 \%$ subvencionado; ou seja, um produto que é considerado pelo agente que fornece habitação, como garantia do direito à moradia digna para o cidadão colombiano. Em contraposição, é expresso nas sentencias que, às vezes, a habitação social concedida por qualquer subvenção, não satisfaz as condições de mobilidade interna, 
privacidade, intimidade, sossego, para a população considerada vulnerável ${ }^{135}$, razão pela qual os demandantes divulgam que o direito à habitação tem sido violado por essas carências espaciais, e, às vezes, expressam que também a sua dignidade, porquanto a sua integridade e a sua saúde está sendo lesada.

Os objetos espaciais em litígio, expostos nos esquemas argumentativos, são considerados, pela jurisprudência da Colômbia e pela política habitacional, bens e serviços duráveis, e são as opções de acesso à moradia, que a população vulnerável prima a respeito da política de habitação da Colômbia. Quando o cidadão atinge algum desses objetos; tanto o agente que fornece a habitação quanto o judiciário exibem que o direito à habitação está sendo garantido para os colombianos.

Diagnosticar áreas residenciais, desde variáveis de indicadores oficiais, tem como alvo revisar o cumprimento de padrões de habitabilidade, e é nesse momento que se estabelece, desde a política habitacional, que uma moradia ou uma área residencial responde a esses padrões. Se o alvo de cumprir com normas já foi alcançado, é suposto que não vai ocorrer nenhum prejuízo para o homem ou seu patrimônio. Indagar por lesões ao morador e ao seu patrimônio por carências espaciais, não é uma tarefa prevista pela política habitacional; corresponderia ao âmbito da jurisprudência, e se faz quando se publicitam essas inadequações espaciais em demandas como sentencias de tutela. Como resultado, a não revisão de possíveis danos para a pessoa e seu patrimônio, é não revisar a experiência do homem quando ele está na busca de recursos espaciais como a moradia adequada.

Discorrer sobre o que seria a moradia adequada, desde variáveis de habitação, é pensá-la apenas para o cumprimento de condições de habitabilidade, expostas nos indicadores habitacionais. Pensar e configurar o que seria a moradia adequada, digna, decorosa, decente ou segura, como adjetivações dadas nas constituições dos países da América Latina ao direito à moradia, e lidar com essas variáveis habitacionais como conteúdo material e objetivo desse direito, o que também poderia incluir a visualização da entidade vulneradora e as lesões para o morador, para estabelecer omissões, atribuições ou intenções das entidades envolvidas no processo de acesso e provisão de habitação, como violação a esse direito.

\footnotetext{
${ }^{135} \mathrm{~A}$ população vulnerável, encontrada nas sentencias corresponde a: idoso - sem renda - com e sem crianças dependentes; mãe ou pai chefe de família, com renda mínima, produto de trabalho informal ou sem renda, com crianças saudáveis, deficientes ou com doença crônica ou terminal; adultos com doença física ou mental, crônica ou terminal; povos indígenas expulsos das suas terras, sem renda; além das condições da população acima apontadas, encontramos que muitos destes requerentes estavam em uma situação de deslocamento forçado. Para uma definição de população vulnerável para a Colômbia, ver Nota de Rodapé №.85.
} 
Ao sistematizar, em esquemas argumentativos, os casos descritos nas sentencias a respeito da violação ao direito à moradia, observamos que não se esgotam as inúmeras situações, existentes no país, a respeito da violação a esse direito; mas refletem, a compreensão do juiz e do cidadão sobre a prática do direito à moradia digna e adequada.

\section{Direito à moradia. Permeabilidade, colateralidade e interdependência dos direitos}

As variáveis dos indicadores de moradia nacionais e do indicador considerado universal, como a moradia adequada do Pidesc de 1991, constituem o componente objetivo e material do direito à habitação para os países da América Latina. $O$ direito à moradia digna da jurisprudência colombiana é invocado como um direito constitucional em seu artigo 51 . Seu conteúdo é a expressão de diversos instrumentos de direito internacional, o que é conhecido como a permeabilidade dos direitos, e que a Colômbia chama de Bloque de Constitucionalidad. Nas sentencias, invoca-se principalmente a noção do Direito à Moradia Adequada da Observação Geral noㄴ, do Pidesc de 1991, para diversas situações.

Outros instrumentos de direito internacional são invocados nas sentencias tais como os Princípios da Moradia Saudável de 1991 da OMS, quando a saúde e a integridade física do morador estão comprometidas. A Observação Geral nำ7 do Pidesc de 1997, os Princípios Pinheiro ou princípios orientadores para deslocamentos forçados de 2005, e a Convenção relativa ao Estatuto dos Refugiados de 1951, quando precisam ser resolvidos assuntos associados a despejos forçados pela violência, por se habitar em áreas de risco, por se morar em zonas de obras de desenvolvimento, por se viver em um lote ou domicílio em qualidade de ocupante ilegal. As sentencias relacionadas com a remoção de população pelo conflito interno da Colômbia, em algumas ocasiões, ao invés de invocar o direito à moradia, apelam ao direito de não se ser deslocado pela força e à restituição; mostrando, nos fatos descritos, que tem acontecido despojo, perda do habitat, abandono da moradia e da terra que dava o sustento econômico; e que na opinião do juiz, o direito à moradia digna não abrange essas consequências no habitat, razão pela qual se aplica o Bloque de Constitucionalidad ou o que é chamado de permeabilidade dos direitos.

A Observação no15 de 2002 do Pidesc, sobre o direito à água, é invocada quando há problemas no fornecimento com qualidade dos serviços básicos, principalmente da água. A Convenção sobre os Direitos da Criança de 1989, a Convenção sobre os Direitos das Pessoas com Deficiência de 2006 e a Convenção sobre a Eliminação de todas as formas de Discriminação contra as Mulheres de 1979, são invocadas quando este tipo de população percebe que está sendo obstaculizado seu direito à habitação, e excluída por seu status de população fraca e minoritária; e quando compreende que 
as ações do agente vulnerador podem lesar a sua saúde e a sua integridade. Nas sentencias em que o requerente sofre de doenças crônicas ou terminais, e por estas condições não acessa a crédito hipotecário, a moradia subvencionada, ou perde o domicilio, apenas invoca-se o Pidesc de 1991.

A essencial necessidade de invocar outros instrumentos de direito internacional para argumentar a violação ao direito à moradia, evidencia-se nas sentencias. Por inferências feitas ao conteúdo dessas figuras jurídicas, consideramos que os juízes têm o discernimento de que o domicílio, visto só como paredes e teto, possui uma conotação de atributos para atender de acordo com padrões descritos em indicadores habitacionais nacionais, os quais estão contidos na noção de direito à moradia digna da Colômbia e no direito à moradia adequada do Pidesc. Assim, o juiz considera que o conteúdo desse direito corresponde só às competências da política habitacional.

A invocação, nas sentencias, dos instrumentos de direito internacional, antes de o direito à moradia digna, é uma posição do juiz no que diz respeito ao conteúdo desse direito, porque acredita que este último não vai cobrir todas as situações sobre moradia, território e habitat ocorridas, por exemplo, no deslocamento forçado de população. Mas os juízes também compreendem que existem outros atributos, não pertencentes ao material da habitação, mas inseridos na sua natureza de abrigo, que estão desenvolvidos em outros instrumentos de direito; e que em caso de serem descumpridos esses atributos, gera-se um dano colateral entre os direitos. Essa colateralidade e interdependência, que é mais do que uma permeabilidade entre os direitos, mostra a moradia em uma conotação socioespacial fora do seu âmbito material. Grande parte dos conflitos, resultado da violação dos direitos habitacionais, estão fundamentados nessa permeabilidade e colateralidade entre os direitos.

A carência no âmbito residencial de algum dos sete elementos que configuram a moradia adequada do Pidesc de 1991: segurança da posse; disponibilidade e qualidade dos materiais, instalações especiais e de serviços básicos e urbanos; acessibilidade econômica e economicidade, habitabilidade e funcionalidade espacial, localização adequada, sem vetores que possam interferir com a segurança física, e com conexão a serviços urbanos, além de atender à adequação cultural; gera dano ao patrimônio; mas também pode gerar dano de tipo pessoal e lesões para o sujeito, e aos objetos de proteção da dignidade. É uma vantagem a noção do direito à moradia adequada não ser um conceito autossuficiente, fechado ou terminado; pois, seria uma utopia registrar todas as deficiências associadas ao habitacional em um único indicador, assim, que, pode ser aplicada a permeabilidade e colateralidade dos direitos. 


\section{Assuntos socioespaciais que violam o direito à moradia}

Os elementos socioespaciais recorrentes em sentencias de tutela, que, expõem a percepção do demandante a respeito da violação ao direito à moradia, foram uma descoberta no levantamento empírico, e, assim, consideramo-los como um padrão jurídico-espacial contido nas sentencias que argumentam o direito à moradia. Esses são: (a) o objeto espacial em litígio, que é um elemento geral ao que o demandante procura acessar ou obter, e sobre o que o demandado tem o controle; (b) a pretensão do demandante sobre o objeto espacial em litígio, que, por sua vez, mostra o procedimento associado com esse objeto; (c) a conduta, como a ação ou resposta do demandado, e que o demandante percebe, é a causa da violação ao direito à habitação, e, em consequência, manifesta-se em (d) tipos de lesão considerados desde o âmbito jurídico. Além de três tipos de elementos socioespaciais nos quais o demandado escuda sua conduta: $\left(c^{1}\right)$ condutas escoradas nas competências, no perfil financeiro do demandado; nos processos reguladores e nas leis; $\left(c^{2}\right)$ condutas amparadas em situações espaciais sobre as quais os demandados dizem não ter controle; $\left(\mathrm{c}^{3}\right)$ condutas resguardadas na atual situação de vulnerabilidade do demandante. Esses elementos não são nomeados dessa maneira nas sentencias, nem conceitualmente em pesquisas que revisam o conteúdo de figuras jurídicas desse tipo, sobre o direito à moradia.

Sobre os elementos socioespaciais nos quais o demandado tem se escudado:

- No primeiro caso $-\mathrm{C}^{1}$, condutas escoradas no perfil do demandado, nos processos reguladores e nas leis -. Essas condutas danificam, segundo narrações nas sentencias, o patrimônio e a integridade física do morador.

- Para o segundo caso - $\mathrm{C}^{2}$, condutas amparadas em situações espaciais -, correspondem a espaços precários como condutas que violam o direito à moradia, e, segundo os demandantes, em determinadas ocasiões, a dignidade; lesando ou ameaçando o patrimônio, a integridade física; motivo pelo qual os demandantes exigem melhores atributos espaciais e, por conseguinte, de condições de vida.

- No caso $-\mathrm{C}^{3}$, condutas resguardadas na atual situação de vulnerabilidade do demandante -. A conduta do demandado pode ser observada no espaço e desde elementos tangíveis. Deparamos nas sentencias, que o demandado escudava essa conduta na fragilidade do demandante, quando, por exemplo expressava que se $o$ vulnerado não fosse criança, idoso, com deficiência física ou mental, doente crônico ou terminal, população minoritária, pobre, debilitado, deslocado, nenhuma das ações que o demandado faz, o teria lesado.

Em consequência, se (c) a conduta não for modificada ou desaparecer; o demandante não vai conseguir (b) a pretensão; razão pela qual a conduta, escorada em algum dos três elementos socioespaciais referidos, geraria uma lesão ou uma ameaça que poderia se manifestar em (d) aspectos tais como: o patrimônio, o mínimo vital, a 
igualdade, a saúde, a integridade física e moral, a intimidade, a privacidade, o sossego, a livre circulação, os objetos de proteção da dignidade; aspectos que são invocados nas sentencias como entidades vulneradas. Além do mais, o requerente expõe essas condutas como desrespeito à sua dignidade, e é quando sofre o que Jacobson (2009) tem chamado de "processos de violação à dignidade". Isso ocorre independentemente da natureza da requerente e do requerido: pessoa natural ou jurídica, instituição pública ou particular. Com a visualização dessas condutas, poderiam se construir alertas a respeito da violação a este direito e à dignidade na experiência espacial, para diminuir essas próprias condutas, e, portanto, os danos aos objetos e à pessoa.

Sobre a situação do demandante, no intervalo de tempo em que é interposta uma demanda em uma acción de tutela, depois a decisão do juiz, e a ação do demandado a respeito de mitigar sua conduta vulneradora, os demandantes expressam nas sentencias, que vivem em adensamento, em moradias de má qualidade, sem água potável e esgoto; da caridade de parentes e amigos em termos de abrigo e comida; sem acesso a crédito para habitação, a saúde, aos serviços de educação. Para quando os demandantes têm recebido uma moradia ou um lote por alguma subvenção, eles promulgam que esses imóveis apresentam problemas de habitabilidade; que não estão equipados para pessoas com deficiência física ou mental; que o estoque de lotes para habitação social e para cultivo da terra estão localizados em áreas de conflito, alguns desses lugares tem minas explosivas no solo, sem água potável para consumo humano e insuficiente para a irrigação da terra para seu cultivo; além dos problemas com a segurança da posse.

Ou seja, antes de ser interposta uma demanda para se exigir garantias a respeito do direito à moradia, os demandantes já têm sofrido danos sobre o patrimônio, lesões na sua saúde, nas suas condições materiais de existência, na sua integridade física e mental; além de que, em algumas situações não podem acessar ao mais básico da moradia - o abrigo adequado -. O demandante e o juiz consideram essas lesões como a situação atual do requerente. Estas pré-existências não são estimadas como elementos que violam o direito à moradia, mas tornam-se situações que violam esse direito. Assim, esses danos não vão ser considerados como tal perante o jurídico, porquanto, ao parecer, o juiz os assume como situações indiretas ao fato que viola 0 direito, e pré-existentes à interposição da demanda.

\section{Três objetos de proteção da dignidade da Corte Constitucional da Colômbia}

Ao revisar o primeiro objeto de proteção da dignidade da Corte Constitucional da Colômbia que é "projetar e manter um plano de vida"; os entes danificados poderiam se referir à pessoa, com lesões à integridade física e moral do sujeito, ao projeto de vida e à liberdade. A proteção das "condições materiais de existência", 
como segundo objeto de proteção da dignidade, visa melhorar condições socioespaciais e condições de vida; sua alteração poderia apresentar tanto uma lesão extrapatrimonial quanto uma lesão ao patrimônio. O respeito a esse objeto de proteção pode ser observado no espaço e no corpo, mas sua vulneração é uma lesão às condições materiais de existência, à integridade física do sujeito, à capacidade de realizar atividades vitais ou prazerosas; também, e às vezes, ao patrimônio. Nas situações nas quais não se protege o objeto "intangibilidade dos bens nãoeconômicos, a integridade física e moral", podem se apresentar lesões geradas pela interferência à privacidade, à intimidade, ao sossego, à integridade física e à moral, causando perturbação, dor e sofrimento, além de lesões físicas.

Desde as lesões evidenciadas, esse Tribunal poderia determinar se a carência, insuficiência ou má qualidade das características de habitação prejudicam algum desses objetos de proteção. $O$ desrespeito a esses objetos de proteção, quando o direito à moradia é violado, pode ser revisado nos fatos narrados nas sentencias de tutela, e abre um caminho para a reflexão sobre as condutas que violam o direito à moradia e que ao mesmo tempo poderiam ferir a integridade do homem.

\section{Conteúdo do direito à moradia}

A moradia adequada, digna, decente, segura, decorosa, confortável, entre outras adjetivações dadas à moradia nas Constituições, não estão delimitadas pelos autores institucionais ou acadêmicos revistos. Essas noções poderiam ser demarcadas pela jurisprudência dos países, em relação com os indicadores de habitação de cada nação, complementadas com variáveis previstas em outros estudos, e com o indicador do Pidesc de 1991, considerado de validez universal. Mas enquanto o direito à moradia para cada país é delimitado, o conteúdo objetivo e material desse direito, adjetivado de variadas formas, continuará a ser só com os indicadores de habitação de cada nação.

O "direito à moradia digna" invoca-se nas sentencias, em primeiro lugar, porque é a qualificação dada à habitação na Constituição vigente da Colômbia. Em segundo lugar, ocorre que quando são invocadas, por sua vez, a habitação e a dignidade como direitos desrespeitados, acontece porque o demandante percebe que sofreu dano subjetivo e com lesão para si, por condições socioespaciais inadequadas; embora essa lesão não seja explícita como uma lesão nas sentencias, mas como a situação do requerente no momento de instaurar a demanda e que expõe que, seu nível de vida está degradando-se. Em contraste, se o demandante exigisse moradia adequada, o dano poderia ser subjetivo, mas o prejuízo é provável que seja definido pelo juiz sobre os bens do sujeito. 
Sobre o patrimônio danificado quando o direito à moradia é violado, existem procedimentos para definir o valor do dano, ou seja, para restaurar o objeto material. Esse objeto material que vai compensar o dano está no domínio da política habitacional, pois corresponde a outro imóvel, seu equivalente em dinheiro ou em espécie. Quando é vulnerada a integridade do homem, suas condições de existência ou seu projeto de vida, como objetos de proteção da dignidade, a lesão é à pessoa, que, em concordância com Fernández-Sessarego (2002), é difícil de ser calculada em dinheiro para a restituição do que foi prejudicado. A restituição do dano aos objetos de proteção da dignidade, num marco de direito à moradia, está aparentemente fora do que são consideradas as competências e os produtos que a política de habitação pode fornecer, assim que está mais perto dos direitos, e associada com a restituição do dano subjetivo, o qual, à primeira vista, ressarcir o dano, não tem valor equivalente em dinheiro ou em espécie.

Os demandantes, advogados, cidadãos e os autores acadêmicos percebem que quando for violado o direito à moradia digna, isto pode se evidenciar nos prejuízos na pessoa e nas suas condições de existência; o que os demandantes chamam de desrespeito à dignidade, indicando, assim, que a dignidade não é um conceito vago, inútil; concordamos, contudo, que deve ser aprofundado em seu conteúdo descritivo e ampliado em sua delimitação no debate sobre direitos humanos. $O$ direito à moradia perde - usando a expressão de Martins, no que diz sobre o conteúdo do direito à cidade -, quando se assume um discurso de termos e palavras em voga, sem explicitar seu conteúdo (2006, p. 44).

A jurisprudência delimita a adjetivação à habitação estabelecida na Constituição de cada país, com base em instrumentos de direito internacional e nas variáveis de déficit habitacional nacionais. No entanto, quando se viola ou ameaça um direito, e se interpõe em forma de uma demanda, como é uma sentencia de tutela, é que se assegura a publicidade é se coloca em evidência o discurso e a promoção ou violação desse direito. Um determinado conflito associado com o habitacional só alcança expressão judicial e publicidade quando a população compreende que o fato viola algum direito, percebe que lesa o patrimônio ou a integridade do homem, identifica o agente vulnerador, eleva esse fato para uma demanda e perante um juiz, e esse fato é uma contravenção a variáveis contidas nos déficits habitacionais. No entanto, vários obstáculos surgem: a pouca delimitação objetiva e material dos direitos habitacionais e seu nível de correspondência com as variáveis de habitação nacionais; o nível de capacidade da população para entender o conteúdo desse direito, e o exercício e compreensão deste direito por parte do juiz, quem media a narração dos fatos em uma sentencia de tutela.

O direito à moradia está configurado para seu desfrute, em qualquer condição de vulnerabilidade e de status do morador. Assim, sobre os direitos, sua promoção é 
necessária, e, antes do que isso, é necessário ampliar o seu conteúdo objetivo e material, para facilitar a compreensão de situações de promoção ou violação dos direitos habitacionais.

O acesso a recursos espaciais como a moradia, os serviços básicos, os serviços urbanos, e o acesso à cidade é o debate geral nas sentencias de Tutela sobre o Direito à Moradia. Martins expõe que o acesso a esses recursos depende do acesso a assentar-se, a um lugar na cidade, e, assim, o tema da moradia é fundamental, sendo, portanto, elemento central na materialização do direito à cidade; mas trata-se de uma questão a se qualificar (2006, p. 42). Afirma que "definir o lugar de todos no espaço urbano e as condições de fruição de um ambiente saudável não é uma demanda do Estado, é uma disputa ampla no conjunto da sociedade" (p. 46).

O debate particular nas sentencias sobre o direito à moradia gira em torno de contratos verbais ou escritos, procedimentos, regulações, normas e leis, variáveis de moradia ou de habitabilidade que não se cumprem; ou porque há uma ausência destes. Nesse obrar, criam-se desconformidades com algum dos componentes da noção de direito à moradia adequada e a moradia digna; e assim, o debate sobre esse direito nas sentencias foca-se no sentido de garantir alguma condição contratual que não está sendo cumprida ou que não existe, de garantir alguma carência espacial contida em variáveis nacionais de habitação. Por outro lado, os demandantes percebem que a dignidade pode ser desrespeitada por contratos, leis, e padrões de habitabilidade não cumpridos ou que não existem. A inter-relação do direito à moradia com o espaço evidencia-se quando se expõe que a dignidade é desrespeitada, e, desse modo, aplicam-se os três objetos de proteção da Corte Constitucional da Colômbia, para mostrar lesões ao homem.

Se nós aceitarmos que o objetivo das demandas sobre o direito à moradia é examinar garantias e conformidade com regulamentos, leis, contratos, variáveis de habitação, não vai ser examinada a inter-relação do sujeito com o espaço, e, destarte, vamos deixar de discutir nas demandas o conteúdo do direito à moradia como necessidade básica, cujo fundamento é sua natureza de abrigo. Assim que estas regulações, leis e semelhantes precisam ser enriquecidas desde a experiência espacial, para que a partir delas, possam-se avaliar as interações do homem com o espaço; pois ele não pode prescindir do espaço, desenvolve-se nele.

Apesar de os juízes tratarem, nas sentencias, geralmente de contratos, indicadores, leis e regulamentos não cumpridos; ou de resolverem danos não considerados nos padrões, regulamentos e procedimentos; eles vão no sentido da construção de critérios para dar conteúdo ao direito à moradia digna, e de instaurar o assunto da permeabilidade e do dano colateral entre os direitos; além de desenvolver a ideia de que a dignidade deve ser protegida, sob o pretexto que a integridade do homem 
poderia ser ameaçada na inter-relação com o espaço. O juiz estimula o uso da adjetivação de "digna" na moradia, para conseguir concretar esse direito. Assim, as sentencias de tutela fornecem uma noção de direito à moradia digna que a jurisprudência vai institucionalizando no campo jurídico e sociopolítico da Colômbia. Esse avanço na legislação, a respeito dos direitos habitacionais, pode se perder quando não tem o campo da política habitacional em correspondência para ser aplicado.

Mesmo quando não encontramos autores que estabeleceram uma diferença entre moradia adequada e a digna, e, deste modo, nos âmbitos estudados continua a se usar ambas noções indistintamente, podemos manifestar que uma moradia não tem caráter de dignidade, no entanto, a noção mais próxima é a moradia adequada em uma relação direta, mas não equivalente. Mesmo assim, ao direito à moradia como um dever ser, imprimisse-lhe uma característica humana. $O$ fato é que, aparentemente, ainda não se encontrou outra maneira de expressar, em uma delimitação do direito à moradia, que a dignidade deve ser protegida, e, assim, que a lesão à integridade do homem deva ser considerada nessa noção.

Nas pesquisas sobre demandas judiciais, analisam-se as questões relativas à deliberação dos tribunais, as relações que interferem, a decisão do juiz ou as diversas decisões a respeito de um caso particular, ou seja, sobre a eficácia da lei, para se chegar, invariavelmente, à conclusão de que, em algum ponto do processo jurídico, há um obstáculo que ameaça a garantia de um direito; conclusão que também visualiza esta investigação, mas não é a conclusão que fecha a abordagem das sentencias de tutela do Tribunal da Colômbia. Nesta pesquisa, o que abordamos foi a demanda: os fatos que o demandante expõe, violam o direito à moradia. $\mathrm{O}$ que nos levou a indagar pelas condutas ou ações dos demandados que ameaçavam ou lesavam um direito, e, por conseguinte, os tipos de lesão desde o âmbito jurídico; para vislumbrar, em fases mais tardias da pesquisa, que um horizonte era verificar em quais entidades poderiam ser observados os danos e lesões; para chegar ao que nomeamos como a dignidade na experiência espacial, construindo, para essa noção, critérios e fatores de observação do desrespeito à integridade do homem, em um marco de violação ao direito à moradia.

A moradia digna é mais do que o acesso físico e econômico a um abrigo, e mais do que um telhado, tendo a ver com assuntos mais qualitativos e relacionados com a integridade do homem, cujo bem-estar do seu corpo e da sua mente devem ser protegidos, quando sem sucesso procura-se acesso à moradia com condições adequadas. Nestes encontros em que se buscam recursos espaciais, é que a dignidade na experiência espacial pode ser ameaçada. 


\section{A dignidade na experiência espacial habitacional num marco de direito à moradia}

No início da pesquisa, estabelecemos discutir só a delimitação do adequado e do digno na moradia. No transcorrer da investigação, vislumbramos a perspectiva e a necessidade de revisar a vulneração ao homem, através de assuntos socioespaciais, num marco de direito à habitação. A palavra "digna", como adjetivo e qualificação da habitação, e compreender que a dignidade pode ter uma dimensão operacional, a qual nos permitiu inferir que a dignidade pode ser observada na integridade do corpo e da mente do homem, e que pode ser lesada pelo espaço em que o homem habita, seja por sua condição pré-existente de vulnerabilidade e/ou pela precariedade do espaço.

O desrespeito à dignidade, eventualmente, pode se visualizar desde as características da moradia, quando a olho nu observam-se carências por inadequadas condições espaciais, ou quando o acesso à moradia é truncado e, assim, não se obtém abrigo. Nesse processo, o morador poderia ter sofrido intromissão no âmbito da sua intimidade, da sua integridade física e moral, ou ter sido excluído por sua condição de fragilidade.

A dignidade, na sua dimensão prática, possibilita desdobrar a experiência espacial, revisando a integridade do sujeito na sua interação com as condições espaciais. Deste modo, revisamos a habitabilidade na habitação em um sentido não restrito as suas paredes e teto ou a suas variáveis de conforto, mas em um sentido amplo, com suas conexões ao urbano. O que nós chamamos da dignidade na experiência espacial é uma forma de compreender a dimensão da dignidade na moradia, surge em uma interação entre indivíduos, às vezes em um contexto de acesso a serviços sociais, quando se está na busca de recursos espaciais como a moradia, ou em seu habitar cotidiano. Há, portanto, um aspecto da dignidade, seu lado ativo, passível de ser alterado.

Como recapitulação, os fatores de observação da dignidade na experiência espacial, para se observar e levantar questões sobre a dignidade na sua dimensão prática, são: 1) o lócus de controle, 2) a posição da pessoa, 3) a origem do desrespeito, 4) as características do contexto, 5) a frequência e a duração da vulneração, 6) o tipo de execução, 7) os âmbitos transgredidos, 8) a percepção, 9) a pretensão, 10) os processos socioespaciais nos quais o agente vulnerador escora a sua conduta, e 11) o tipo de lesão desde o âmbito do jurídico.

O que mostram esses fatores é a necessidade de rever o dano subjetivo e a lesão ao sujeito, gerados por ações que violam o direito à habitação, tanto em situações de acesso à moradia, como quando essa é habitada, com independência da posse e do 
status do morador. Também demonstram que quando afirmamos que a dignidade é precária, ou seja, poderia ser vulnerada, é quando se precisa de proteção social.

\subsection{Temas para futuras pesquisas}

Vários temas para futuras pesquisas foram surgindo no percorrer desta pesquisa. Há investigações desde a área da saúde a respeito de inadequações espaciais que lesam a integridade do homem. Mas é pouco abordada a relação das variáveis de habitação de um país, em relação com a saúde e o bem-estar da população, para fins de política de habitação, para a delimitação do que constitui uma moradia adequada, e para sua concretização como direito.

A relação habitação-saúde é um tema pouco abordado no campo da arquitetura e do urbanismo. A WHO expõe que se precisa de evidência científica sobre como a moradia e o ambiente construído prejudicam a saúde, com vista a prever uma ampla gama de doenças e lesões não intencionais, as quais poderiam ser mitigadas ou prevenidas eficazmente através de uma melhor e mais adequada habitação, e aplicando os princípios da Moradia Saudável da OMS. (WORLD HEALTH ORGANIZATION, 2010).

Existe consenso de que a coleta de dados estatísticos e indicadores econômicos, sociais e ambientais constituem um elemento estrutural para o desenvolvimento de políticas públicas. No entanto, não é visto, claramente, a relevância de dados estatísticos e de indicadores de habitação para a concretização dos direitos humanos, entre estes, os da habitação. Isso se evidencia na baixa participação do cidadão na demanda de direitos habitacionais, e na limitação de situações nas quais o juiz abrange às competências desse direito. Seguindo o pensamento de Pisarello (2003), é relevante indagar pelo conteúdo objetivo e material do direito à moradia, com a premissa de que esse corresponde às variáveis e indicadores de habitação; e que trata de uma análise relacional entre os indicadores de moradia e os direitos habitacionais, pouco examinada. Mas também para evidenciar as lesões jurídicas ao sujeito e não só ao patrimônio, devido às condições socioespaciais inadequadas.

Estamos cientes de que os fatores e critérios propostos para se observar a dignidade na experiência espacial precisam de aplicação empírica, nos estudos de caso com grupos de população homogênea e não homogênea, para se avaliar e aprofundar nos apontamentos apresentados no Capítulo 7. Fica para investigações posteriores construir critérios mais precisos a respeito da dignidade na experiência espacial, quando esta pode ficar comprometida em ações que promovem ou violam o direito à moradia, e em contextos de acesso a recursos espaciais, como a habitação - tanto 
como dimensão da dignidade na moradia, quanto atributo do direito à moradia adequada -.

Pesquisas que têm se aprofundado nos estudos da dignidade como sendo esta uma experiência, como a de Jacobson - e ainda que tenha sido desde a área da saúde -, podem fornecer critérios sobre a natureza e as consequências da promoção ou violação do direito à habitação, visando o desenvolvimento de políticas de habitação, planejamento de programas de habitabilidade e de qualidade de vida.

Com suporte na investigação de Jacobson (2009), a compreensão da dignidade na sua dimensão operacional pode ser útil para advogados e profissionais que trabalham em serviços sociais, fornecendo recursos associados a necessidades básicas, mas que precisam atuar num marco de direitos; portanto, engajados em um tipo de trabalho que thes vai permitir aproveitar os processos sociais e os critérios da promoção da dignidade, que esta autora propõe em sua taxonomia da dignidade, a fim de melhorar as condições de vida e de garantir os direitos humanos. Assim, essa taxonomia pode ser de valor para eles, mas também servir como suporte para ampliar o conteúdo do direito à moradia na perspectiva da promoção ou violação dos direitos do morador, ao fornecer, em palavras desta pesquisadora, um mapa de possíveis pontos de intervenção e linguagem comum para falar de dignidade.

Situações particulares na Colômbia, como o conflito armado interno, para o qual se assinou um pôs-acordo em junho de 2016, nos Diálogos de Paz na Havana, Cuba, vão acolher novos conflitos sobre a ocupação, o uso e a posse do solo e da moradia, mas os velhos problemas não irão desaparecer, vão ficar com antigas e novas condutas que violarão o direito à moradia, e que poderiam ser evidenciadas em demandas jurídicas. Temas expostos nas sentencias, tais como: áreas residenciais localizadas em áreas de conflito armado e violência; as ocupações ilegais; os despejos devido às obras de desenvolvimento, à violência e ao desastre e sem garantia de futuro de mais um teto; a perda do habitat, da moradia e da terra para se obter dela sustento; população que, por sua condição particular de saúde física e mental, não pode acessar a um crédito hipotecário ou a um domicilio subvencionado, ou que, ao acessá-los, a moradia não é adequada a sua condição e lesa ainda mais sua condição; entre outras situações, vão continuar a violar o direito à habitação, e, ocasionalmente, alguns fatos vão perturbar a dignidade na experiência espacial, além do direito à cidade; mas com a complexidade de que essas situações estão inseridas em um processo de justiça transicional, como se sucede com esses Diálogos de Paz em Havana ${ }^{136}$.

${ }^{136}$ A definição de justiça transicional foi tirada de uma conferência ditada por Rodrigo Uprimny, e referese a "como uma sociedade enfrenta violações em massa de direitos humanos no passado, ou seja, que 
Nessas situações, produto do conflito armado interno na Colômbia, nas quais ocorrem deslocamentos forçados, o que é uma infração forte ao direito internacional humanitário, precisa-se que sejam conhecidas as lesões ao sujeito e não só as lesões ao patrimônio. Mas existem poucos estudos que relacionam ser despejado à força de seu habitat, com danos para a saúde, para a integridade do homem, para as condições materiais de existência. Porém, fica como tema por se desenvolver, o da sanção restituitiva ${ }^{137}$ para o agente vulnerador que despejou ao morador pela força. As interrogações que ficam a respeito são estas: sendo o vitimador condenado à prisão, isso ressarciria a conduta de espoliação? E qual seria o tipo de indenização para a vítima que foi desapropriada do seu habitat?

Um catálogo de processos e consequências da violação ao direito à habitação seria fundamental para perceber os usos normativos da dignidade, com vista a expandir o conhecimento sobre a dignidade na experiência espacial como dimensão da dignidade na moradia, e como atributo do direito à moradia adequada.

não enfrenta casos isolados, mas o debate sobre o que fazer com milhares de desaparecidos, homicídios, em um esforço por se sair da guerra de forma negociada, mesmo com a guerrilha em ação. Esta decisão [de aplicar a justiça transicional] é tomada por um país no momento cujo direito internacional já tem mecanismos específicos de controle, pois, anteriormente, ocorria o perdão e o esquecimento desses crimes. Hoje não é possível porque existem mecanismos internacionais buscando reconhecimento às vítimas; por isso é que a solução torna-se mais difícil desde o judiciário no âmbito de uma justiça transicional [processos de justiça em uma fase de transição]. A justiça transicional foi aplicada, por exemplo, na Argentina e no Chile após o conflito, e assim decide-se o que fazer com as vítimas. Na Colômbia ainda há o conflito, e parte dos vitimários estão na mesa de negociação com representação das vítimas. Portanto, isso é que constitui para a Colômbia a justiça transicional: um mandato de fazer justiça e garantir os direitos das vítimas, enquanto o conflito continua" (UPRIMNY, 2016).

${ }^{137}$ A sanção deve ser considerada como restituitiva, porquanto a situação está inserida em um processo de justiça transicional. 


\section{REFERÊNCIAS ${ }^{138}$}

ACADEMIA DE CIENCIAS DE LA URSS. Manual de economía política. Tradução de Wenceslao Roces. 3a. Reimpresión 1969. ed. México: Grijalbo, 1967. 706 p.

ALARCÓN-BERNAL, E. Las primeras constituciones democráticas en Colombia (18101815). Bogotá: Universidad Nacional de Colombia, Facultad de Ciencias Políticas y Sociales, Bogotá, Tesis presentada como requisito parcial para optar al título de Magíster en Derecho. Director: Dr.Bernd Marquardt, 2013. 211 p.

ALBUQUERQUE DE OLIVEIRA, A. Interface entre bioética e direitos humanos: o conceito ontológico de dignidade humana e seus desdobramentos. Revista Bioética, Brasilia, v. 15, n. 2, $2007.170-185.200$ Disponível <http://www.redalyc.org/articulo.oa?id=361533246002>. Acesso em: 30 abr. 2016.

ANDORNO, R. Human Dignity and Human Rights as a Common Ground for a Global Bioethics. Journal of Medicine and Philosophy, p. 223-240, 2009. Doi: 10.1093/jmp/jhp023. Disponível em: <http://jmp.oxfordjournals.org/content/34/3/223.short>. Acesso em: 01 ago. 2015.

Bioética y dignidad de la persona. 2a edición. ed. España: Tecnos, 2012. 183 p.

ANDRÉU, J. Las técnicas de análisis de contenido: una revisión actualizada. España: Fundación Centro de Estudios Andaluces, 2002. 34 p. Disponível em: <http://public.centrodeestudiosandaluces.es/pdfs/S200103.pdf>. Acesso em: 01 maio 2012.

ANTONUCCI, D. et al. UN-Habitat: das declarações ao compromissos. São Paulo: Romano Guerra Editora, 2010. 160 p.

AÑON-ROIG, M. J. Necesidades y derechos: un ensayo de fundamentación. Madrid: Centro de Estudios Constitucionales, 1994. 350 p.

ASAMBLEA GENERAL. Resolución 53 (I). Vivienda y Urbanismo. Organización de las Naciones Unidas. 1946.

Resolución 61 (I). Creación de la Organización Mundial de la Salud. Organización de las Naciones Unidas. 1946a.

Resolución 217 (III). Carta Internacional de los Derechos del Hombre. Item A. Declaración Universal de los Derechos del Hombre. Organización de las Naciones Unidas. 1948.

138 De acordo com a Associação Brasileira de Normas Técnicas (ABNT). NBR 6023. 
ASAMBLEA GENERAL. Resolución 537 (VI). Vivienda, urbanismo y planificación rural. Organización de las Naciones Unidas. 1952.

Resolución 1676 (XVI). Urbanización. Organización de las Naciones Unidas. 1961.

Resolución 1710 (XVI). Decenio de las Naciones Unidas para el Desarrollo. Programa de cooperación económica internacional (I). Organización de las Naciones Unidas. 1961a.

Resolución 2200 (XXI). Pacto Internacional de Derechos Económicos, Sociales y Culturales, Pacto Internacional de Derechos Civiles y Políticos y Protocolo Facultativo de Derechos Civiles y Políticos. Organización de las Naciones Unidas. 1966.

Resolución 2398 (XXIII). Problemas del medio humano. Organización de las Naciones Unidas. 1968.

Resolución 2626 (XXV). Estrategia Internacional del Desarrollo para el Segundo Decenio de las Naciones Unidas para el Desarrollo. Organización de las Naciones Unidas. 1970.

Resolución 33/193. Preparativos para una Estrategia Internacional del Desarrollo para el Tercer Decenio de las Naciones Unidas para el Desarrollo. Organización de las Naciones Unidas. 1979.

Resolución 52/193. Primer Decenio de las Naciones Unidas para la Erradicación de la Pobreza. Organización de las Naciones Unidas. 1998.

Resolución 54/282. Proyecto de Declaración del Milenio. [Sin remisión previa a una Comisión Principal (A/54/L.89)]. Organización de las Naciones Unidas. 2000.

Resolución 55/2. Declaración del Milenio. [Sin remisión previa a una Comisión Principal (A/55/L.2)]. Organización de las Naciones Unidas. 2000a.

BARDIN, L. Análisis de contenido. 3a. ed. Madrid: Ediciones Akal S.A., 2002. 177 p.

BELLO, ANDRÉS. Ley 57 de 1887. Código Vivil. Colombia. 1857. Disponível em: <http://www.alcaldiabogota.gov.co/sisjur/normas/Norma1.jsp?i=39535>. Acesso em: 01 ago. 2015.

BERNAT, G. La legislación colonial española de Indias, 2003. Disponível em: <http://www.gabrielbernat.es/espana/leyes/index.html>. Acesso em: 31 jan. 2016.

BOHÓRQUEZ, V.; AGUIRRE, J. Las tensiones de la dignidad humana: Conceptualización y aplicación en el derecho Internacional de los derechos humanos. Revista Sur, Colombia, v. 6, n. 11, p. 41-63, dic 2009. Disponível em: <http://www.scielo.br/scielo.php?pid=S180664452009000200003\&script=sci_abstract\&tIng=es>. Acesso em: 01 nov. 2015.

BOLTVINIK, J. Medición multidimensional de pobreza. América Latina de precursora a rezagada. Sociedad \& Equidad, n. 5, p. 4-29, Enero 2013. 
BOTERO, C.; JARAMILLO, J. F. El conflicto de las Altas Cortes colombianas en torno a la tutela contra sentencias. Foro constitucional iberoamericano, n. 12, p. 42-81, 2006. Disponível em: <http://dialnet.unirioja.es/servlet/articulo?codigo=2242218>. Acesso em: 01 nov. 2014.

BRASIL. Código Civil. Lei no 10.406 de 10 de Janeiro de 2002. Disponível em: <http://www.planalto.gov.br/ccivil_03/leis/2002/L10406.htm>. Acesso em: 01 fev. 2014.

BROOKES, B. C. Biblio-, sciento-, infor-metrics? What are we talking about? Informetrics 89/90, $\quad$ p. $31-43, \quad 1990 . \quad$ Disponível em: <https://doclib.uhasselt.be/dspace/bitstream/1942/857/1/Brookes31.PDF>. Acesso em: 01 mar. 2014.

COHRE. Centre on Housing Rights \& Evictions COHRE, 2014. Disponível em: <http://www.cohre.org/about-us>. Acesso em: 08 mar. 2014.

COMISIÓN INTERAMERICANA DE DERECHOS HUMANOS. Declaración Americana de los Derechos y Deberes del Hombre. Bogotá: Organización de los Estados Americanos, 1948. Disponível em: <www.oas.org/es/cidh/mandato/Basicos/declaracion.asp >. Acesso em: 10 set. 2013.

COMITÉ DE DERECHOS ECONÓMICOS, SOCIALES Y CULTURALES. EI derecho a una vivienda adecuada (Art.11, párr. 1): 13/12/91. CESCR Observación general № 4 (General Comments). $6^{\circ}$ período de sesiones (1991). United Nations, Oficina del Alto Comisionado de las Naciones Unidas para los Derechos Humanos. v. E/1992/23, 1991.

El derecho a una vivienda adecuada, Observación general 7, (párrafo 1 del artículo 11 del Pacto), los desalojos forzosos (16 período de sesiones, 1997). United Nations, 1997.

CONSEJO ECONÓMICO Y SOCIAL. Resolución 830 (XXXII). Situación social en el mundo (tema 3). E/3555. [S.I.]: Organización de las Naciones Unidas, v. E/3555, 1961.

CRAVEN, M. History, pre-history and the right to housing in international law. Em: LECKIE, S. National Perspectives on Housing Rights. [S.I.]: Martinus Nijhoff Publishers, 2003. Cap. 2, p. 43-64.

DEFENSORÍA DEL PUEBLO. Sistema de seguimiento y evaluación de la política pública de vivienda a la luz del derecho a una vivienda digna y adecuada. Bogotá: Programa de Seguimiento y Evaluación de la Política Pública en Derechos Humanos, ProSeDHer, 2007. $117 \mathrm{p}$.

El derecho a una vivienda digna y adecuada. En la Constitución, la Jurisprudencia y los Instrumentos Internacionales de Derechos Humanos. Bogotá: Programa de Seguimiento y Evaluación de la Política Pública en Derechos Humanos ProSeDHer, 2009. 240 p. 
DEFENSORÍA DEL PUEBLO. El derecho a una vivienda digna y adecuada. Evaluación de las condiciones del componente lugar en proyectos de vivienda de interés social (VIS) y vivienda de interés prioritario (VIP), en la ciudad de Bogotá. Bogotá: Programa de Seguimiento y Evaluación de Políticas Públicas en Derechos Humanos, ProSeDHer, 2012. $168 \mathrm{p}$.

Defensoría del Pueblo Colombia, 2014. Disponível em: <http://www.defensoria.org.co/red/index.php?_secc=01>. Acesso em: 20 fev. 2014.

DEFENSORÍA DEL PUEBLO. Defensoría del Pueblo. Colombia, 2016. Disponível em: $<$ http://www.defensoria.gov.co/es/public/institucional/114/Misi\%C3\%B3n-y-

Visi\%C3\%B3n.htm>. Acesso em: 20 jan. 2016.

DIAZ, S. La Real Expedición Botánica. Credencial Historia, Bicentenario de una nación en el mundo; Historia de la ciencia y la tecnología en Colombia, n. 240, 2009. Disponível em: <http://www.banrepcultural.org/blaavirtual/revistas/credencial/diciembre2009/botanica.htm>. Acesso em: 01 Out 2015.

DNP. Estudio 5. Lineamientos de política de reasentamiento de población afectada por proyectos de desarrollo, de protección ambiental y de prevención de desastres en Colombia. Resumen ejecutivo. Bogotá: Departamento Nacional de Planeación (DNP), 2006. $4 \mathrm{p}$.

ECONOMIC AND SOCIAL COUNCIL. Report of the Eighth Session. Supplement No.5. E/2569. E/CN.3/192. New York: United Nations. Economic and Social Council. Statistical Comission, v. E/2569 E/CN.3/192, 1954. Disponível em: <http://www.un.org/en/ecosoc/docs/resdec1946_2000.asp>. Acesso em: 04 nov. 2012.

Statistical Commission. Report of the ninth session. Supplement No.7. New York: United Nations. Economic and Social Council. Statistical Comission, 1956. Disponível em: <http://www.un.org/en/ecosoc/docs/resdec1946_2000.asp>. Acesso em: 04 nov. 2012.

EL CONGRESO DE COLOMBIA. Ley 387 de 1997. Por la cual se adoptan medidas para la prevención del desplazamiento forzado; la atención, protección, consolidación y estabilización socioeconómica de los desplazados internos por la violencia en la República de Colombia. $1997 . \quad$ Disponível em: $<$ http://www.alcaldiabogota.gov.co/sisjur/normas/Norma1.jsp?i=340>. Acesso em: 01 mar. 2013.

Ley 1537 de 2012. Por la cual se dictan normas tendientes a facilitar y promover el desarrollo urbano y el acceso a la vivienda y se dictan otras disposiciones. 2012. Disponível em: <http://www.alcaldiabogota.gov.co/sisjur/normas/Norma1.jsp?i=47971>. Acesso em: 01 mar. 2013.

Ley 1448 de 2011. Por la cual se dictan medidas de atención, asistencia y reparación integral a las víctimas del conflicto armado interno y se dictan otras disposiciones. $2011 . \quad$ Disponível em: <http://www.alcaldiabogota.gov.co/sisjur/normas/Norma1.jsp?i=43043. Acesso em: 01 jun. 2015. 
EL PRESIDENTE DE LA REPÚBLICA DE COLOMBIA. Decreto 2591 de 1991. Por el cual se reglamenta la acción de tutela consagrada en el artículo 86 de la Constitución Política. $1991 . \quad$ Disponível em: <http://www.corteconstitucional.gov.co/lacorte/DECRETO\%202591.php>. Acesso em: 01 jun. 2015.

$\begin{array}{ccccc} & \text { Decreto } 4800 \text { de 2011. Por el cual se reglamenta la Ley } 1448 \text { de } 2011 \text { y se dictan } \\ \text { otras } & \text { disposiciones. } & 2011 . & \text { Disponível } & \text { em: }\end{array}$ <http://www.centrodememoriahistorica.gov.co/descargas/registroEspecialArchivos/Decreto4 800-11RegalmentarioLey1448-11.pdf>. Acesso em: 01 jun. 2015.

Decreto 2569 de 2014. Mediante el cual se reglamentan artículos 182 de Ley 1450 de 2011, 62, 64, 65, 66, 67, 68 de Ley 1448 de 2011, se modifican artículos 81, 83 del Decreto 4800 de 2011, se deroga el inciso $2^{\circ}$ del artículo 112 del Decreto 4800 de 2011. 2014. Disponível em: <http://www.unidadvictimas.gov.co/es/asistencia-yatenci\%C3\%B3n-humanitaria/decreto-2569-de-2014/13114>. Acesso em: 01 jun. 2015.

ELIZALDE, A. Satisfacción de necesidades humanas para una vida digna: Línea de Dignidad y necesidades humanas fundamentales. Em: SUSTENTABLE, P. C. S. Línea de dignidad. Desafíos sociales para la sustentabilidad. Chile: Programa Cono Sur Sustentable, 2002. Cap. Capítulo II. Aportes de la línea de dignidad para el desarrollo sustentable: desde la vida mínima hacia la vida digna, p. 113-132.

ESCALANTE, M. E. M. Variáveis de habitação e adjetivações à moradia. O mínimo dos direitos habitacionais. $3^{\circ}$ ClHEL. Congresso Internacional de Habitação no Espaço Lusófono, São Paulo, Brasil, Setembro 7, 8, 92015.

FERES, J. C.; MANCERO, X. El método de la Necesidades Básicas Insatisfechas (NBI) y sus aplicaciones en América Latina. Santiago de Chile: CEPAL, v. No.7. CEPAL - SERIE Estudios Estadísticos y Prospectivos, 2001. 52 p.

FERNÁNDEZ-SESSAREGO, C. Hacia una nueva sistematización del daño a la persona. Cuadernos de Derecho, $\mathbf{N}^{\circ}$ 3, Lima, n. 3, p. 14, Septiembre 1993. Disponível em: http://dike.pucp.edu.pe/bibliotecadeautor_carlos_fernandez_cesareo/articulos/ba_fs_9.PDF> Acesso em: 20 jan. 2016.

Disponível

Daño al proyecto de vida. Derecho PUC, Lima, n. 50, p. 47-97, Diciembre 1996. <http://dike.pucp.edu.pe/bibliotecadeautor_carlos_fernandez_cesareo/articulos/ba_fs_7.PDF >. Acesso em: 01 fev. 2016.

Apuntes sobre el daño a la persona. Ius et Veritas, Edición Especial, Lima, p. 40, Noviembre $2002 . \quad$ Disponível em: <http://dike.pucp.edu.pe/bibliotecadeautor_carlos_fernandez_cesareo/articulos/ba_fs_4.PDF >. Acesso em: 01 fev. 2016.

. ¿Existe un daño al proyecto de vida? Revista Persona, Argentina, n. 11, p. 17, $2002 ?$ Disponível em: <http://www.revistapersona.com.ar/Persona11/11Sessarego.htm>. Acesso em: 01 fev. 2016. 
FERNÁNDEZ-SESSAREGO, C. Carlos Fernández Sessarego. Obras escritas de mi autoría desde 1944 a la fecha, 2010. Disponível em: <http://carlosfernandezsessarego.blogspot.com.co/2010/01/mi-curriculum.html\#commentform>. Acesso em: 01 fev. 2016.

FRESNEDA, O. La medida de necesidades básicas insatisfechas (NBI) como instrumento de medición de la pobreza y focalización de programas. Santiago de Chile: CEPAL, v. Estudios y perspectivas No.18, 2007. 198 p.

GALVIS-CASTRO, F. Tendencias jurisprudenciales de la Corte Constitucional colombiana en materia de derecho a la vivienda. Bogota, D.C.: Universidad Nacional de Colombia, Sede Bogotá. Facultad de Derecho, Ciencias Políticas y Sociales. Departamento de Derecho-Área Curricular, Serie Estudios Jurídicos de la Universidad Nacional de Colombia, 2014. $162 \mathrm{p}$.

GARCÍA-VARGAS, C.; PARRA-DÍAZ, G. El daño moral y a la vida de relación, y su aplicación en el sistema jurídico colombiano. Bucaramanga: Universidad Industrial de Santander. Facultad de Ciencias Humanas. Escuela de Derecho y Ciencia Política. Bucaramanga, Trabajo de grado presentado como requisito para optar al título de abogado, 2007. 260 p.

GENERAL ASSEMBLY. A/2929. Annotations on the text of the draft International Covenants on Human Rights. Agenda Item 28. Part II. Annexes tenth session. New York: United Nations, $1955.134 \quad$ p. 13 Disponível em: <http://www2.ohchr.org/english/issues/opinion/articles1920_iccpr/docs/A-2929.pdf>. Acesso em: 23 out.. 2013.

HIC. Habitat International Coalition. América Latina, 2014. Disponível em: <http://www.hical.org/hic.cfm>. Acesso em: 10 fev. 2014.

HOYOS, I. M. De la dignidad y de los derechos humanos. Una introducción al pensar analógico. Bogotá: Temis S.A., 2005. 358 p.

ILO. Employment, growth and basic needs: a one-world problem; the international 'basicneeds strategy' against chronic poverty. Prepared by the ILO International Labour Office and the decisions of the 1976 world Employment Conference. Washington: International Labour Organization, Overseas Development Council ILO, 1976. 226 p.

Meeting basic needs. Strategies for eradicating mass poverty and unemployment. Conclusions of the World Employment Conference 1976. Geneva: International Labour Office (ILO), 1977. 60 p.

INTERNAL DISPLACEMENT MONITORING CENTRE. NORWEGIAN REFUGEE COUNCIL. Global Overview 2015. People internally displaced by conflict and violence. Geneva: [s.n.], 2015. 96 p.

JACKSON, P. Antecedentes de los Objetivos de Desarrollo del Milenio: Cuatro decenios de lucha en pro del desarrollo en las Naciones Unidas, 2007. Disponível em: <http://www.un.org:80/wcm/content/site/chronicle/lang/es/home/archive/issues2007/>.

Acesso em: 10 abr. 2013. 
JACOBS, D. Demystification of Bibliometrics, Scientometrics, Informetrics and Webometrics. In: OCHOLLA, D.; EVANS, N.; EDITORS. Demystifying and Popularizing LIS Research in Modern Times. South Africa: University of Zululand, 2010. p. 30-43. Disponivel em: <http://citeseerx.ist.psu.edu/viewdoc/download?doi=10.1.1.464.8390\&rep=rep1\&type=pdf>. Acesso em: 01 jun. 2014.

JACOBSON, N. Dignity and health: A review. Social Science \& Medicine, Canada, n. 64, p. 292-302, 2007. Disponível em: <www.elsevier.com/locate/socscimed. 0277-9536/\$>. Acesso em: 01 ago. 2012.

A taxonomy of dignity: a grounded theory study. BMC International Health and Human Rights, Canada, n. 3, p. 9, 2009. Disponível em: <http://www.biomedcentral.com/1472-698X/9/3>. Acesso em: 01 ago. 2012.

Dignity and health. Nashville: Vanderbilt University Press, 2012. 223 p.

. Conversations about dignity. Some things about the beginning, 2012a. Disponível em: <http://commonrespect.wordpress.com/2012/05/15/some-things-about-the-beginning/>. Acesso em: 29 jul. 2013.

. OLIVER, V.; KOCH, A. An urban geography of dignity. Health \& Place, Canada, n. 15, p. 725-731, 2009a. Elsevier doi:10.1016/j.healthplace.2008.11.003. Disponível em: <http://www.sciencedirect.com/science/article/pii/S135382920800138X>. Acesso em: 01 ago. 2012.

KASTMAN, R. La medición de las necesidades básicas insatisfechas en los censos de población. Uruguay: Comisión Económica para América Latina y el Caribe CEPAL. Oficina de Montevideo, 1995. $33 \mathrm{p}$.

KILLMISTER, S. Dignity: not such a useless concept. J Med Ethics, n. 36, p. 160-164, 2010. Doi: 10.1136/jme.2009.031393. Disponível em: <http://jme.bmj.com/content/36/3/160.full.pdf+html>. Acesso em: 01 ago. 2012.

KRIPPENDORFF, K. Metodología de análisis de contenido: teoría y práctica. Tradução de Leandro Wolfson. Barcelona: Ediciones Paidós Ibérica, S.A., 1990. 266 p.

LAWANI, S. M. Bibliometrics: Its Theoretical Foundations, Methods and Applications. Libri 1981, v. 31, n. 4, p. 294-315, 1981. Disponível em: <http://www.unc.edu/ jdwilbur/201/bibliometrics.lawani.pdf>. Acesso em: 01 ago. 2013.

LECKIE, S. The UN Committee on Economic, Social and Cultural Rights and the Right to Adequate Housing: Towards an Appropriate Approach. Human Rights Quarterly, n. 11, p. 522-560, 1989. Disponível em: <http://heinonline.org>. Acesso em: 10 mar. 2014.

From housing needs to housing rights: An analysis of the right to adequate housing under international human rights law. London: The International Institute for Environment and Development (IIED), 1992. 109 p. 
LECKIE, S. Where it matters most: making international Housing Rights meaningful at the national level. In: LECKIE, S. National Perspectives on Housing Rights. [S.I.]: Martinus Nijhoff Publishers, 2003. Cap. 1, p. 3-42.

Right to adequate housing. Em: LECKIE, S. Litigating Economic, Social and Cultural Rights: Legal Practitioners Dossier. Geneva: The Centre on Housing Rights and Evictions (COHRE), 2006 Cap. I. Law, p. 66-88.

LÓPEZ, D. El derecho de los jueces. Obligatoriedad del precedente constitucional, análisis de sentencias y líneas jurisprudenciales y teoría del derecho judicial. Segunda. ed. Colombia: Legis, 2006. 366 p.

MACKLIN, R. Dignity is a useless concept. It means no more than respect for persons or their autonomy. BMJ, v. 327, p. 2, 2003. Disponível em: <http://www.bmj.com/content/327/7429/1419 >. Acesso em: 01 nov. 2012.

MANTILLA DE VALERA, L. El daño moral en Colombia: un estudio sobre la nueva tendencia del 'daño a la persona'. Colombia: Universidad Católica de Colombia. Facultad de Derecho, Trabajo de grado para optar al título de abogado, 2015. 75 p.

MANTILLA-ESPINOSA, F.; OÑATE-ACOSTA, T. La dignidad de la Corte Constitucional. Bogotá: Grupo Editorial lbañez, 2013. 104 p.

MARRAUD, H. Beve curso de esquemas argumentativos. Madrid: Universidad Autónoma de $\quad$ Madrid, 2016.28 p. 128 Disponível <https://www.academia.edu/5709775/Breve_curso_de_esquemas_argumentativos>. Acesso em: 01 abr. 2016.

MARTINS, M. L. R. Moradia e mananciais: tensão e diálogo na metrópole. São Paulo: FAUUSP/FAPESP, 2006. 206 p.

MASLOW, A. Motivación y personalidad. Barcelona: Sagitario, 1975.

MATTSON, D.; CLARK, S. Human dignity in concept and practice. Policy Sci, USA, n. 44, p. 303-319, 2011. Disponível em: <http://link.springer.com/article/10.1007/s11077-010-9124-0>. Acesso em: 01 mar. 2013.

MAX-NEEF, M. Desarrollo a escala humana. Conceptos, aplicaciones y algunas reflexiones. Montevideo: Editorial Nordan-Comunidad, 1993. 148 p.

MEJÍA-ESCALANTE, M. Necessidades básicas: bens e serviços duráveis da moradia adequada. Revista INVI, Chile, v. 30, n. 85, p. 147-180, 2015.

MEJÍA ESCALANTE, M. Vivienda adecuada y derecho a la ciudad. XXXI Encuentro y XVII Congreso Habitar la ciudad, tiempo y espacio. ARQUISUR, Córdoba, Argentina, Septiembre 25-27, 2013. 
MELO, J. O. Documentos constitucionales colombianos, 1810-1815. Colombia: http://www.jorgeorlandomelo.com/documentos.htm, 2015.435 p. Disponível em: <http://www.jorgeorlandomelo.com/bajar/documentosconstitucionales1.pdf>. Acesso em: 06 ago. 2015.

MINAGRICULTURA. Decreto 2164 de 1995. Por el cual se reglamenta parcialmente el Capítulo XIV de la Ley 160 de 1994 en lo relacionado con la dotación y titulación de tierras a las comunidades indígenas. Santa Fe de Bogotá: Ministerio de Agricultura, Colombia, 1995. Disponível em: <http://www.mininterior.gov.co/lainstitucion/normatividad/decreto-2164-de-1995>. Acesso em: 06 nov. 2015.

MINISTERIO DE VIVIENDA, CIUDAD Y TERRITORIO. Colombia: Cien años de políticas habitacionales. Bogotá: Panamericana Formas e Impresos S.A., 2014. 280 p.

NACIONES UNIDAS. Convenio de Ginebra relativo a la protección debida a las personas civiles en tiempo de guerra (Convenio IV). Organización de las Naciones Unidas, 1949. Disponível em: <http://www.acnur.org/biblioteca/pdf/0189.pdf?view=1>. Acesso em: $01 \mathrm{fev}$. 2013

. Convención sobre el Estatuto de Refugiados. Organización de las Naciones
$\begin{aligned} & \text { Unidas, } \\ & \text { <http://www.acnur.org/t3/fileadmin/scripts/doc.php?file=biblioteca/pdf/0005>. Acesso em: } 01\end{aligned}$
fev. 2013.

Definición y medición internacional del nivel de vida. Guia provisional. Nueva York: Organización de las Naciones Unidas, v. E/CN.3/270/Rev.1 No.Venta: 60.IV.7, 1961. 20 p.

Disponível

em: <http://unstats.un.org/unsd/publication/seriese/seriese_cn3_270_rev1s.pdf>. Acesso em: 04 nov. 2012.

Convención Internacional sobre la Eliminación de todas las Formas de Discriminación Racial. Adoptada y abierta a la firma y ratificación por la Asamblea General en su Resolución 2106 A (XX), de 21 de diciembre de 1965. Oficina del Alto Comisionado de las Naciones Unidas para los Derechos Humanos. Organización de las Naciones Unidas. 1965. Disponível em: <http://www2.ohchr.org/spanish/law/cerd.htm>. Acesso em: 01 fev. 2013.

Convención sobre la Eliminación de Todas las Formas de Discriminación de la Mujer. Adoptada y abierta a la firma y ratificación, o adhesión, por la Asamblea General en su Resolución 34/180, de 18 de diciembre de 1979. Entrada en vigor: 3 de septiembre de 1981, de conformidad con el artículo 27 (1). Serie Tratados de Naciones Unidas № 2. Organización de las Naciones Unidas. 1979. Disponível em: <http://www.un.org/womenwatch/daw/cedaw/text/sconvention.htm>. Acesso em: $01 \mathrm{fev}$. 2013. 
NACIONES UNIDAS. Convención sobre los Derechos del Niño. Adoptada y abierta a la firma y ratificación por la Asamblea General en su Resolución 44/25, de 20 de noviembre de 1989. Entrada en vigor: 2 de septiembre de 1990, de conformidad con el artículo 49. Organización de las Naciones Unidas. 1989. Disponível em: <http://www.acnur.org/t3/fileadmin/scripts/doc.php?file=biblioteca/pdf/0021>. Acesso em: 01 fev. 2013.

Convención internacional sobre la protección de los derechos de todos los trabajadores migratorios y de sus familiares. Adoptada por la Asamblea General en su Resolución 45/158, de 18 de diciembre de 1990. Organización de las Naciones Unidas. 1990. Disponível em: <http://www2.ohchr.org/spanish/law/cmw.htm>. Acesso em: 01 fev. 2013.

El derecho al agua (artículos 11 y 12 del Pacto Internacional de Derechos Económicos, Sociales y Culturales). 29 período de sesiones (2002). Observación General № 15. Organización de las Naciones Unidas, v. E/C.12/2002/11, 2002. Disponível em: $<$ http://confdts1.unog.ch/1\%20SPA/Tradutek/Derechos_hum_Base/CESCR/00_1_obs_grales_Cte\%20 Dchos\%20Ec\%20Soc\%20Cult.html\#GEN15>. Acesso em: 01 abril. 2014.

Manual sobre la Restitución de las Viviendas y el Patrimonio de Refugiados y Personas Desplazadas. Aplicación de los "Principios Pinheiro". Organización de las Naciones Unidas, 2005.

Declaración de las Naciones Unidas sobre los derechos de los pueblos indígenas. 61/295. Sin remisión previa a una Comisión Principal (A/61/L.67 y Add.1) Organización de las Naciones Unidas, 2007. Disponível em: <http://www.un.org/esa/socdev/unpfii/documents/DRIPS_es.pdf>. Acesso em: 01 fev. 2013.

Convención sobre los Derechos de las Personas con Discapacidad. Organización de las Naciones Unidas, 2008. Disponível em: <http://www.un.org/esa/socdev/enable/documents/tccconvs.pdf>. Acesso em: 01 mar. 2013.

Resultados sobre el desarrollo sostenible, 2013. Disponível em: <http://www.un.org/es/development/devagenda/sustainable.shtml>. Acesso em: 02 set. 2013.

Naciones Unidas. Conferencias, reuniones y eventos, 2015. Disponível em: <http://www.un.org/es/events/pastevents/unchs_1996/>. Acesso em: 01 abr. 2015.

Naciones Unidas, 2016. Disponível em: <http://www.un.org/es/sections/aboutun/overview/index.html>. Acesso em: 01 fev. 2014.

NORDENFELT, L. The Varieties of Dignity. Health Care Analysis, v. 12, n. 2, June, p. 69-81, 2004. Doi: 1065-3058/04/0600-0069/1 C. Disponível em: <http://www.ncbi.nlm.nih.gov/pubmed/15487812>. Acesso em: 01 fev. 2014.

OIT. Convenio relativo a las condiciones de empleo de los trabajadores de las plantaciones. Organización Internacional del Trabajo (OIT), 1958. Disponível em: <http://www.ilo.org/dyn/normlex/es/f?p=NORMLEXPUB:12100:0::NO::P12100_ILO_CODE:C 110>. Acesso em: 01 fev. 2013. 
OIT. R.115 - Recomendación sobre la vivienda de los trabajadores, 1961 (Núm. 115). Geneva: Organización Internacional del Trabajo (OIT), 1961. Disponível em: <http://www.ilo.org/dyn/normlex/fr/f?p=NORMLEXPUB:12100:0::NO::P12100_INSTRUMENT _ID,P12100_LANG_CODE:312453,es>. Acesso em: 02 mar. 2013.

Planning for basic needs in Latin America. Final Report: Bogotá Workshop Seminar. Bogotá: Organización Internacional del Trabajo (OIT). Programa Mundial de Empleo, v. PREALC/171, $1979 . \quad 73 \quad$ p. $\quad$ Disponível em: <http://www.ilo.org/public/libdoc/ilo/1979/79B09_411_engl.pdf>. Acesso em: 02 mar. 2012.

C161 - Convenio sobre los servicios de salud en el trabajo, 1985 (núm. 161). [S.I.]. 1985. Adopción: Ginebra, 71르 reunión CIT (25 junio 1985) - Estatus: Instrumento actualizado (Convenios Técnicos). Organización Internacional del Trabajo (OIT). Disponível em:

<http://www.ilo.org/dyn/normlex/es/f?p=NORMLEXPUB:12100:0:NO:P12100_ILO_CODE:C1 61>. Acesso em: 02 mar. 2013.

OLANO, H. ¿Cómo analizar sentencias de la Corte Constitucional Colombiana? Revista Iberoamericana de Derecho Procesal Constitucional, n. 3, p. 335-346, 2005. Disponível em: <http://dialnet.unirioja.es/servlet/articulo?codigo=2530991 >. Acesso em: 01 maio 2013.

ONU. Protocolo adicional a la Convención Americana sobre Derechos Humanos en materia de derechos económicos, sociales y culturales "Protocolo de San Salvador". 1988. Disponível em: <http://www.oas.org/juridico/spanish/Tratados/a-52.html>. Acesso em: 01 mar. 2012

Anexo estadístico del informe ODM de 2013. Portal oficial de la ONU para los indicadores de los ODM. [S.I.]. 2013. Disponivel em: <http://mdgs.un.org/unsd/mdg/Host.aspx?Content=Products\%2fProgressReports.htm>. Acesso em: 01 jan. 2016.

ONU-HÁBITAT. Estado de las ciudades de América Latina y El Caribe 2012. Rumbo a una nueva transición urbana. Nairobi: ONU-Hábitat. Programa de las Naciones Unidas para los Asentamientos Humanos, 2012. 196 p.

Déficit habitacional en América Latina y El Caribe. Una herramienta para el diagnóstico y el desarrollo de políticas efectivas en vivienda y hábitat. Nairobi: Programa de las Naciones Unidas para los Asentamientos Humanos (ONU-HABITAT), 2015. 67 p.

ORGANIZACIÓN DE LAS NACIONES UNIDAS. Principios rectores de los desplazamientos internos. Derechos Humanos, éxodos en masa y personas desplazadas. E/CN.4/1998/53/Add.2, Organización de las Naciones Unidas. 1998. Disponível em: <http://www.hchr.org.co/documentoseinformes/documentos/html/informes/onu/resdi/ECN-4-1998-53-ADD-2.html>. Acesso em: 01 mar. 2014.

ORGANIZACIÓN MUNDIAL DE LA SALUD. Constitución de la Organización Mundial de la Salud [OMS]. Nueva York: Organización de las Naciones Unidas, 1946. Disponível em: <http://www.who.int/governance/eb/who_constitution_sp.pdf>. Acesso em: 01 julho 2013. 
ORGANIZACIÓN MUNDIAL DE LA SALUD. Principios de higiene de la vivienda. Ginebra: Organización Mundial de la Salud [OMS], 1990. 44 p. Disponível em: <http://apps.who.int/iris/bitstream/10665/38629/1/9243561278_spa.pdf>. Acesso em: 01 jul. 2013.

Organización Mundial de la Salud [OMS], 2012. Disponível em: <http://www.who.int/about/es/>. Acesso em: 10 nov. 2012.

ORTIZ, E. Producción social de la vivienda y el hábitat. Bases conceptuales y correlación con los procesos habitacionales. México, D.F.: Habitat International Coalition HIC, 2012. $87 \mathrm{p}$.

PASTERNAK, S. Habitação e saúde. Estudos avançados, v. 30, n. 86, p. 51-66, Jan/Apr 2016. Disponível em: <http://www.scielo.br/scielo.php?script=sci_arttext\&pid=S010340142016000100051>. Acesso em: 01 jul. 2016.

PINKER, S. The Stupidity of Dignity. The Richard Dawkins Foundation for Reason and Science. News, p. 17, 2008. Disponível em: <http://old.richarddawkins.net/articles/2567>. Acesso em: 26 jun. 2013.

PISARELLO, G. Vivienda para todos: un derecho en (de)construcción. El derecho a una vivienda digna y adecuada como derecho exigible. Barcelona: Icaria, 2003. 284 p.

PORTO EDITORA. Dicionário da Língua Portuguesa com Acordo Ortográfico [em linha], 2003. Disponível em: <http://www.infopedia.pt/dicionarios/lingua-portuguesa/tutela>. Acesso em: 01 Out 2015.

PRITCHARD, A. Statistical bibliography or bibliometrics? Journal of Documentation, v. 25, n. 4, p. 348-349, dec 1969. Disponível em: <https://www.researchgate.net/publication/236031787_Statistical_Bibliography_or_Bibliometr ics>. Acesso em: 01 ago. 2013.

PYRRHO, M.; CORNELLI, G.; GARRAFA, V. Dignidad humana, reconocimiento y operacionalización del concepto. Acta Bioethica, n. 15 (1), p. 65-69, 2009. Disponível em: <http://www.scielo.cl/scielo.php?script=sci_arttext\&pid=S1726-569X2009000100008>.

Acesso em: 01 fev. 2013.

REAL ACADEMIA ESPAÑOLA. Diccionario de la lengua española, 2015. Disponível em: <http://lema.rae.es/drae/?val=tutela>. Acesso em: 01 ago. 2015.

RESTREPO, A. Acercamiento conceptual a la dignidad humana y su uso en la Corte Constitucional colombiana. Diálogos de Derecho y Política, n. 6, p. 19, 2011. Disponível em: <http://tesis.udea.edu.co/dspace/bitstream/10495/1982/1/Acercamiento\%20conceptual\%20a \%20la\%20dignidad\%20humana\%20y\%20su\%20uso\%20en\%20la\%20Corte\%20Constitucion al\%20en\%20Colombia.pdf>. Acesso em: 01 Abril 2015.

ROSATI, H. La América española colonial. Siglos XVI, XVII y XVII, 1996. Disponível em: <http://www7.uc.cl/sw_educ/historia/america/html/indice.html>. Acesso em: 01 ago. 2015. 
SCHR, VOICE, ICVA. EI Proyecto de la Esfera. Carta Humanitaria y Normas Mínimas de Respuesta Humanitaria en Casos de Desastre. Ginebra, Suiza: Steering Committee for Humanitarian Response (SCHR). Voluntary Organisations in Cooperation in Emergencies (VOICE). International Council of Voluntary Agencies (ICVA), 2004. 408 p.

SCHROEDER, D. Dignity: Two Riddles and Four Concepts. Cambridge Quarterly of Healthcare Ethics, USA, n. 17, p. 230-238, 2008. doi: 10.1017/S0963180108080262. Disponível em: <http://journals.cambridge.org/action/displayAbstract?fromPage=online\&aid=1781912\&fileld =S0963180108080262>. Acesso em: 01 nov. 2012.

Human Rights and Human Dignity. An Appeal to Separate the Conjoined Twins. Ethic Theory Moral Prac. Springer, n. 15, p. 323-335, 2012. Disponível em: <http://link.springer.com/article/10.1007/s10677-011-9326-3>. Acesso em: 01 nov. 2012.

SECRETARIA DE DIREITOS HUMANOS DA PRESIDÊNCIA DA REPÚBLICA - SDH/PR. Por uma cultura de direitos humanos. Direito à Moradia Adequada. Brasilia: Coordenação Geral de Educação em SDH/PR, Direitos Humanos, Secretaria Nacional de Promoção e Defesa dos Direitos Humanos, 2013. 76 p.

SEN, A. Sobre conceptos y medidas de pobreza. Comercio Exterior, p. 310-322. Traducción al español, de Julio Boltvinik y Francisco Vásquez, de los capítulos 2 y 3 de Sen 'Poverty and Famines. An essay on Entitlement and Deprivation' (1981), Abril 1992. Disponível em: $<\mathrm{http}$ ://revistas.bancomext.gob.mx/rce/magazines/257/2/RCE2.pdf>. Acesso em: 01 ago. 2013.

STRAUSS, A.; CORBIN, J. Pesquisa qualitativa: técnicas e procedimentos para o desenvolvimento de teoria fundamentada. Tradução de Lucinne de Oliveira da Rocha. Porto Alegre: Artmed, 2008. 288 p.

SULMASY, D. The varieties of human dignity: a logical and conceptual analysis. Med Health Care and Philos. Springer, p. 8, March 2012. Disponível em: <http://link.springer.com/article/10.1007/s11019-012-9400-1>. Acesso em: 01 dez. 2012.

TAGUE-SUTCLIFFE, J. An introduction to informetrics. Information Processing \& Management, Great Britain, v. 28, n. 1, p. 1-3, 1992. Disponível em: <http://ac.elscdn.com/030645739290087G/1-s2.0-030645739290087G-main.pdf?_tid=475c448c-ddcd11e3-b9f0-00000aab0f01\&acdnat=1400336128_ff71630a22a348f2aa61b7f152c04fb2>. Acesso em: 01 mar. 2014.

UN-HABITAT. Guía para el monitoreo de la Meta 11 "Para el año 2020 haber mejorado sustancialmente la vida de por lo menos $\mathbf{1 0 0}$ millones de habitantes de asentamientos precarios". Nairobi: Programa Asentamientos Humanos de las Naciones Unidas, 2003. 24 p.

UNITED NATIONS. Declaration of the United Nations Conference on the Human Environment. Stockholm: United Nations, 1972. Disponível em: <http://www.undocuments.net/aconf48-14r1.pdf>. Acesso em: 01 fev. 2013. 
UNITED NATIONS. Provisional guidelines on statistics of the distribution of income, consumption and acumulation of households. New York: United Nations: Department of Economic and Social Affairs. Statistical Office, v. ST/ESA/STAT/SER.M/61. Sales No.E.77.XVII.11, $1977 . \quad 100 \quad$ p. $\quad$ Disponível <http://unstats.un.org/unsd/publication/SeriesM/SeriesM_61E.pdf>. Acesso em: 01 maio 2012.

International Covenant on Economic, Social and Cultural Rights. Declarations and Reservations. Treaty Collections. IV 3. United Nations, 2015. Disponível em: <https://treaties.un.org/Pages/ViewDetails.aspx?mtdsg_no=IV-3\&chapter=4\&lang=en>. Acesso em: 01 jan. 2015.

UPRIMNY, R. Conferencia "Miradas al Pos-Conflicto en Colombia". Universidad Nacional de Colombia, Sede Medellín. Centro de pensamiento UN. En Hábitat, Ciudad y Territorio: Paz y Posacuerdo. Medellín, Colombia, Lunes 16 de mayo de 2016. Hora 6:00 p.m. - 8:00 p.m. 2016.

URBIZAGÁSTEGUI, R. A bibliometria: história, legitimação e estrutura. Para entender a ciência da informação / Lídia Maria Batista Brandão Toutain: organizadora, Salvador, Brasil, $\quad$ p. 185-217, 2007. Disponível em: <http://www.academia.edu/1390400/A_BIBLIOMETRIA_HISTORIA_LEGITIMA\%C3\%87\%C 3\%83O_E_ESTRUTURA>. Acesso em: 23 ago. 2013.

VANTI, N. Da bibliometria à webometria: uma exploração conceitual dos mecanismos utilizados para medir o registro da informação e a difusão do conhecimento. Ciência da Informação, Brasília, v. 31, n. 2, p. 152-162, maio/ago 2002. Disponível em: <http://www.scielo.br/pdf/ci/v31n2/12918.pdf>. Acesso em: 01 mar. 2014.

WORLD HEALTH ORGANIZATION. International Workshop on Housing, Health and Climate Change: Developing guidance for health protection in the built environment mitigation and adaptation responses. Meeting report. Geneva: World Health Organization (WHO), 2010. 28 p. Disponivel em: <http://www.who.int/hia/house_report.pdf>. Acesso em: 01 fev. 2016.

\section{Constituições dos países da América Latina e da Espanha}

ARGENTINA. CONSTITUCIÓN [1994]. Constitución Política de la Nación Argentina. 22 de agosto de 1994. 1994. Disponivel em: <http://www.constitution.org/cons/argentin.htm>. Acesso em: 01 jun. 2012.

BOLIVIA. CONSTITUCIÓN [2004]. Constitución Política del Estado. Ley de 13 de abril de 2004. Bolivia. 2004. Disponivel em: <https://www.icrc.org/ihlnat.nsf/0/5d1aeb893a3b098ac125705300346e54/\$FILE/Bolivia.constitucion.ESP.pdf>. Acesso em: 01 jun. 2012. 
BRASIL. CONSTITUIÇÃO [1988]. Constituição da República Federativa do Brasil de 1988. 1988. Disponivel em: <http://www.planalto.gov.br/ccivil_03/Constituicao/Constituicao.htm>. Acesso em: 01 jul. 2012.

CHILE. CONSTITUCIÓN [2005]. Constitución Política de la República de Chile. Decreto Supremo $\quad N^{\circ} 100.2005 .2$ Chile. Disponivel em: <https://www.leychile.cl/Navegar?idNorma=242302>. Acesso em: 01 jun. 2012.

COLOMBIA. CONSTITUCIÓN [1991]. Constitución Política de Colombia. 1991. Disponivel em: $\quad$ <ttp://www.registraduria.gov.co/IMG/pdf/constitucio-politica-colombia-1991.pdf>. Acesso em: 01 jun. 2012.

COLOMBIA. CONSTITUCIÓN DEL SOCORRO [1810]. Acta de la Constitución del Estado Libre e Independiente del Socorro. 1810. Junta del Socorro. Em: MELO, J. O. Documentos constitucionales colombianos, 1810-1815.

Colombia: http://www.jorgeorlandomelo.com/documentos.htm, 2015. p. 3-6. Disponivel em: $<$ http://www.jorgeorlandomelo.com/bajar/documentosconstitucionales1.pdf>. Acesso em: 01 ago. 2015.

COLOMBIA. CONSTITUCIÓN DE TUNJA [1811]. Constitución de la República de Tunja. 1811. Asamblea de los Representantes de las Provincias. Em: MELO, J. O. Documentos constitucionales colombianos, 1810-1815. Colombia: http://www.jorgeorlandomelo.com/, 2015. p. 66-88. Disponível em: <http://www.jorgeorlandomelo.com/bajar/documentosconstitucionales1.pdf>. Acesso em: 01 ago. 2015.

COLOMBIA. CONSTITUCIÓN DE CUNDINAMARCA [1811]. Constitución de la República de Cundinamarca. 1811. Serenísimo Colegio Revisor y Electoral. Em: MELO, J. O. Documentos constitucionales colombianos, 1810-1815. http://www.jorgeorlandomelo.com/, 2015. p. 7-48. Disponivel em: <http://www.jorgeorlandomelo.com/bajar/documentosconstitucionales1.pdf>. Acesso em: 01 ago. 2015.

COLOMBIA. CONSTITUCIÓN DE LA NUEVA GRANADA [1811].. Acta de la Federación de las Provincias Unidas de Nueva Granada. 1811. Serenísimos Colegios Electorales y Constituyentes. Em: MELO, J. O. Documentos constitucionales colombianos, 1810-1815. Colombia: http://www.jorgeorlandomelo.com/, 2015. p. 49-65. Disponivel em: <http://www.jorgeorlandomelo.com/bajar/documentosconstitucionales1.pdf>. Acesso em: 01 ago. 2015

COLOMBIA. CONSTITUCIÓN DE LA GRAN COLOMBIA [1821]. Constitución de la Gran Colombia. 1821. Congreso de Cúcuta. Disponivel em: <http://www.alcaldiabogota.gov.co/sisjur/normas/Norma1.jsp?i=13690>. Acesso em: 01 out. 2015.

COLOMBIA. CONSTITUCIÓN DE LOS ESTADOS UNIDOS DE COLOMBIA [1863]. Constitución Política de los Estados Unidos de Colombia. 1863. Disponivel em: <http://www.alcaldiabogota.gov.co/sisjur/normas/Norma1.jsp?i=13698>. Acesso em: 01 out. 2015. 
COLOMBIA. CONSTITUCIÓN [1886]. Constitución Política de la República de Colombia. 1886. Disponivel em: <http://www.alcaldiabogota.gov.co/sisjur/normas/Norma1.jsp?i=7153>. Acesso em: 01 out. 2014.

COSTA RICA. CONSTITUCIÓN [1949]. Constitución Política de la República de Costa Rica. $1949 . \quad$ Disponivel em: <http://pdba.georgetown.edu/Parties/CostaRica/Leyes/constitucion.pdf>. Acesso em: 01 jun. 2012.

CUBA. CONSTITUCIÓN [1992]. Constitución de la República de Cuba. 1992. Disponivel em: <http://www.asamblea.gob.pa/cep/contitucion_del_1972_reforma.pdf>. Acesso em: 01 jul. 2012.

DON CARLOS II. LEYES DE INDIAS [1680]. Recopilación de Leyes de los Reynos de las Indias. 1680. España: Magestad Catolica El Rey Don Carlos II Nvestro Señor. Disponível em: <http://www.congreso.gob.pe/ntley/LeylndiaP.htm>. Acesso em: 01 fev. 2013.

ECUADOR. CONSTITUCIÓN [2008]. Constitución de la República del Ecuador. 2008. Disponivel em: <http://www.asambleanacional.gov.ec/documentos/Constitucion-2008.pdf>. Acesso em: 01 jul. 2012.

EL SALVADOR. CONSTITUCIÓN [1983]. Constitución Política de la República de EI Salvador de 1983, actualizada a reforma introducida por el DL №56, del 06.07.2000. 1983. Disponivel em: <http://www.asamblea.gob.sv/eparlamento/indice-legislativo/buscador-dedocumentos-legislativos/constitucion-de-la-republica>. Acesso em: 01 jun. 2012.

ESPAÑA. CONSTITUCIÓN [1978]. Constitución Española. 1978. Disponivel em: <http://www.senado.es/web/conocersenado/normas/constitucion/index.html>. Acesso em: 01 set. 2013.

ESPAÑA. CARTA DE BAYONA [1812]. Carta de Bayona. Junta De Bayona. 1812. Disponivel em: <http://www.congreso.es/docu/constituciones/1812/Bayona_cd.pdf>. Acesso em: 01 fev. 2016.

GUATEMALA. CONSTITUCIÓN [1993]. Constitución Política de la República de Guatemala. (Reformada por Acuerdo legislativo No. 18-93 del 17 de Noviembre de 1993). 1993.

Disponivel

em:

<http://cc.gob.gt/index.php?option=com_content\&view=article\&id=219:constitucionpdf\&catid =36: catpublicaciones\&ltemid=67>. Acesso em: 01 jul. 2012.

HAITÍ. CONSTITUCIÓN [1987]. Constitución Política de Haití. 1987. Disponivel em: <https://bonoc.files.wordpress.com/2012/04/constitucion-1983-haiti.pdf>. Acesso em: 01 jul. 2012.

HONDURAS. CONSTITUCIÓN [1982]. Constitución Política. Decreto N 131. 11 de Enero de 1982. Disponivel em: <https://www.oas.org/dil/esp/Constitucion_de_Honduras.pdf>. Acesso em: 01 jun. 2012. 
MÉXICO. CONSTITUCIÓN [1917]. Constitución Política de los Estados Unidos Mexicanos. Última Reforma DOF 29-07-2010. 1917. Disponivel em: <http://www.diputados.gob.mx/LeyesBiblio/htm/1.htm>. Acesso em: 01 jun. 2012.

NICARAGUA. CONSTITUCIÓN [2003]. Constitución Política de Nicaragua. 2003. Disponivel em: <http://www.mem.gob.ni/media/file/MARCO\%20LEGAL/LEYES/CONSTITUCION\%20POLITI CA.pdf>. Acesso em: 01 jun. 2012.

PANAMÁ. CONSTITUCIÓN [2004]. Constitución Política de la República de Panamá. 2004. Esta edición de la Constitución Política de 1972 está ajustada a los Actos Reformatorios de 1978, al Acto Constitucional de 1983, a los Actos Legislativos No. 1 de 1993 y No. 2 de 1994, y al Acto Legislativo No.1 de 2004. Texto de 15 de noviembre de 2004. Disponivel em: <http://www.asamblea.gob.pa/cep/contitucion_del_1972_reforma.pdf>. Acesso em: 01 jun. 2012.

PARAGUAY. CONSTITUCIÓN [1992]. Constitución de la República de Paraguay. 1992. Disponivel em: <http://www.oas.org/juridico/spanish/mesicic2_pry_anexo3.pdf>. Acesso em: 01 jun. 2012.

PERÚ. CONSTITUCIÓN [1993]. Constitución Política del Perú. 1993. Disponivel em: <http://portal.jne.gob.pe/informacionlegal/Constitucin\%20y\%20Leyes1/CONSTITUCION\%20 POLITICA\%20DEL\%20PERU.pdf>. Acesso em: 01 jul. 2012.

PUERTO RICO. CONSTITUCIÓN [1952]. Constitución del Estado Libre Asociado de Puerto Rico. $1952 . \quad$ Disponivel em: <http://www2.pr.gov/ogp/Bvirtual/test2/PDF/Derechos\%20Civiles/CONST/CONST.pdf>. Acesso em: 01 jun. 2012.

REPÚBLICA DOMINICANA. CONSTITUCIÓN [2010]. Constitución Política de la República Dominicana. Publicada en la Gaceta Oficial No. 10561, del 26 de enero de 2010. 2010. Disponivel em: <http://www.senado.gob.do/senado/Portals/0/Documentos/constituciones/const-2010.pdf>. Acesso em: 01 jun. 2012.

URUGUAY. CONSTITUCIÓN [1967]. Constitución de la República Oriental del Uruguay. 1967. Disponivel em: <https://www.presidencia.gub.uy/normativa/constitucion-de-larepublica>. Acesso em: 01 jun. 2012.

VENEZUELA. CONSTITUCIÓN [1999]. Constitución de la República Bolivariana de Venezuela. 1999. Disponivel em: <http://www.bcv.org.ve/c3/constitucionvzla022009.pdf>. Acesso em: 01 jun. 2012. 


\section{Institutos Estatísticos dos países da América Latina}

DANE - COLOMBIA. Metodología Déficit de Vivienda. Bogotá: Departamento Administrativo Nacional de Estadística DANE, 2009. 59 p. ISBN 79. Disponivel em: <http://www.dane.gov.co/index.php/poblacion-y-demografia/censos>. Acesso em: 01 jun. 2012.

DGEEC - PARAGUAY. Dirección General de Estadística, Encuestas y Censos de Paraguay DGEEC. Disponivel em: <http://www.dgeec.gov.py/>. Acesso em: 01 out. 2012.

DIGESTYC - EL SALVADOR. Dirección General de Estadística y Censos El Salvador DIGESTYC. VI Censo de población. V Censo de vivienda 2007, 2008. Disponivel em: <http://www.digestyc.gob.sv/index.php/temas/des/poblacion-y-estadisticas-

demograficas.html>. Acesso em: 1 out. 2012.

FUNDAÇÃO JOÃO PINHEIRO. Déficit habitacional no Brasil. Municipios selecionados e microrregiões geográficas. 2a. ed. Belo Horizonte: Fundação Jõao Pinheiro. Centro de Estatística e Informações, 2005. 111 p. Disponível em: <http://www.fjp.gov.br/index.php/indicadores-sociais/deficit-habitacional-no-brasil>. Acesso em: 01 junho 2013.

FUNDAÇÃO JOÃO PINHEIRO. Governo de Minas Gerais. 2013. Disponível em: $<$ http://www.fjp.mg.gov.br/index.php/produtos-e-servicos1/2742-deficit-habitacional-no-brasil3>. Acesso em: 01 out. 2013.

FUNDAÇÃO JOÃO PINHEIRO. Déficit habitacional municipal no Brasil 2010. Belo Horizonte: Fundação João Pinheiro. Centro de Estatística e Informações, 2013a. 78 p.

INE - BOLIVIA. Instituto Nacional de Estadística de Bolivia - INE. Disponível em: $<w w w . i n e . g o b . b o>$. Acesso em: 01 out. 2012.

INE - CHILE. Instituto Nacional de Estadísticas de Chile - INE. Disponível em: <http://www.ine.cl>. Acesso em: 01 out. 2012.

INE - GUATEMALA. Instituto Nacional de Estadística de Guatemala C.A - INE. Disponível em: <http://www.ine.gob.gt/np/encovi/encovi2006.htm>. Acesso em: 01 out. 2012.

INE - HONDURAS. Instituto Nacional de Estadística de Honduras - INE. Disponível em: <www.ine.gob.hn>. Acesso em: 01 out. 2012.

INE - URUGUAY. Instituto Nacional de Estadística de la República Oriental de Uruguay - INE. Disponìvel em: <www.ine.gub.uy>. Acesso em: 01 out. 2012.

INE - VENEZUELA. Instituto Nacional de Estadística de la República Bolivariana de Venezuela - INE. Disponível em: $<h t t p: / / w w w . i n e . g o v . v e / i n d e x . p h p ? o p t i o n=c o m \_c o n t e n t \& v i e w=c a t e g o r y \& i d=95 \& l t e m i d=26>$. Acesso em: 01 out. 2012. 
INEC - COSTA RICA. Instituto Nacional de Estadística de Costa Rica - INEC. Disponível em: <http://www.inec.go.cr/Web/Home/GeneradorPagina.aspx>. Acesso em: 01 out. 2012.

INEC - ECUADOR. Instituto Nacional de Estadística y Censos de Ecuador- INEC. Disponível em: <http://www.inec.gob.ec/cpv/?TB_iframe=true\&height=450\&width=800'\%20rel=slbox >. Acesso em: 01 out. 2012.

INEC - PANAMÁ. Instituto Nacional de Estadistica y Censo de Panamá - INEC. Disponível em: <http://estadisticas.contraloria.gob.pa/Resultados2010/tabulados.aspx>. Acesso em: 01 out. 2012.

INEGI - MÉXICO. Instituto Nacional Estadística y Geografía de México - INEGI. 2010. Disponível em: <http://www.inegi.org.mx/est/contenidos/espanol/metodologias/censos/marco_conceptual_cp v2010.pdf>. Acesso em: 01 out. 2012.

INEGI. Síntesis metodológica y conceptual del Censo de Población y Vivienda 2010. México: Instituto Nacional de Estadística y Geografía - INEGI, 2010a. 81 p. Disponível em: <www.inegi.org.mx>. Acesso em: 01 out. 2013.

INEI - PERÚ. Instituto Nacional de Estadística e Informática de Perú - INEI. Disponível em: $<$ http://iinei.inei.gob.pe/iinei/RedatamCpv2007.asp?id=ResultadosCensales?ori=C.>. Acesso em: 01 out. 2012.

INIDE - NICARAGUA. Instituto Nacional de Información de Desarrollo de Nicaragua - INIDE. Disponível em: <http://www.inide.gob.ni/>. Acesso em: 01 out. 2012.

INSTITUTO DE ESTADÍSTICAS DE PUERTO RICO. Instituto de Estadísticas de Estado Libre Asociado de Puerto Rico. Disponível em: <http://www.estadisticas.gobierno.pr/iepr/Estadisticas/Basesdedatos/Demograf\%c3\%ada.as px\#censo>. Acesso em: 01 out. 2012.

MINISTÉRIO DAS CIDADES. Déficit habitacional no Brasil. Municipios selecionados e microregiôes geográficas. 2a. ed. Belo Horizonte: Fundação João Pinheiro, Centro de Estatística e Informações, 2005. 102 p.

MINISTERIO DE VIVIENDA, CONSTRUCCIÓN Y SANEAMIENTO DE PERÚ. Ministerio de Vivienda, Construcción y Saneamiento de Perú. Disponível em: <http://www.vivienda.gob.pe/destacados/vivienda.aspx>. Acesso em: 01 out. 2012.

MINVU - CHILE. Ministerio de Vivienda y Urbanismo de Gobierno de Chile - MINVU. Disponível em: <http://www.minvu.cl/opensite_20070212170245.aspx>. Acesso em: 01 out. 2012.

ONE - CUBA. Oficina Nacional de Estadística e Información de la República de Cuba - ONE. Disponível em: <http://www.one.cu/trimestralindicadoresvivienda.htm>. Acesso em: 01 out. 2012. 
ONE - REPÚBLICA DOMINICANA. Oficina Nacional de Estadística de República Dominicana - ONE. Disponível em: <http://www.one.gob.do/>. Acesso em: 01 oct. 2012.

SUBSECRETARIA DE DESARROLLO URBANO Y VIVIENDA. ARGENTINA. Subsecretaria de Desarrollo Urbano y Vivienda. Argentina. Disponível em: <http://www.vivienda.gov.ar/unqui/anexometodologico.php>. Acesso em: 1 oct. 2012.

\section{Sentencias de Tutela e Sentencias de Constitucionalidad da Corte Constitucional da Colômbia (C.C.)}

C.C. COLOMBIA. Corte Constitucional de Colombia (C.C.). Auto 099-2013. Sala Especial de Seguimiento a la Sentencia T-025 de 2004 y sus autos de cumplimiento. Relator: Magistrado Ponente Luis Ernesto Vargas Silva.

Corte Constitucional de Colombia (C.C.). Sentencias T-016-2014; T-197-2014; T198-2014; T-736-2013. Relator: Magistrado Ponente Alberto Rojas Ríos.

Corte Constitucional de Colombia (C.C.). Sentencias T-617-1995; T-382-1993; T412-1992. Relator: Magistrado Ponente Alejandro Martínez Caballero.

. Corte Constitucional de Colombia (C.C.). Sentencia T-927-2012. Relator: Magistrado Ponente Alexei Julio Estrada.

. Corte Constitucional de Colombia (C.C.). Sentencias T-1165-2001; C-383-1999. Relator: Magistrado Ponente Alfredo Beltrán Sierra.

Corte Constitucional de Colombia (C.C.). Sentencia T-626-2000. Relator: Magistrado Ponente Álvaro Tafur Galvis.

Corte Constitucional de Colombia (C.C.). Sentencias T-473-2008; T-1091-2005; T363-2004. Relator: Magistrado Ponente Clara Inés Vargas Hernández.

. Corte Constitucional de Colombia (C.C.). Sentencia T-210-1994. Relator: Magistrado Ponente Eduardo Cifuentes Muñoz.

Corte Constitucional de Colombia (C.C.). Sentencias T-881-2002; T-958-2001; C936-2003. Relator: Magistrado Ponente Eduardo Montealegre Lynett.

Corte Constitucional de Colombia (C.C.). Sentencias T-190-1999; T-572-1999; T696-1996. Relator: Magistrado Ponente Fabio Morón Díaz.

Corte Constitucional de Colombia (C.C.). Sentencias T-049-2014; T-163-2014. Relator: Magistrado Ponente Gabriel Eduardo Mendoza Martelo. 
C.C. COLOMBIA. Corte Constitucional de Colombia (C.C.). Sentencias T-825-2014; T-8852014. Relator: Magistrado Ponente Gloria Stella Ortiz Delgado.

. Corte Constitucional de Colombia (C.C.). Sentencias T-585-2008. Relator: Magistrado Ponente Humberto Antonio Sierra Porto.

Corte Constitucional de Colombia (C.C.). Sentencias T-362-2014; T-379-2014; T625-2014; T-777-2014; T-781-2014; T-790-2014; T-409-2013; T-534-2013; T-602-2013; T761-2013; T-349-2012; T-702-2011; C-370-2014; C-881-2014. Relator: Magistrado Ponente Jorge Ignacio Pretelt Chaljub.

Corte Constitucional de Colombia (C.C.). Sentencias T-397-2014; T-398-2014; T672-2014; T-680-2014; T-749-2014; T-801-2014; T-971-2014; T-264-2012; T-501-2012; T857-2012; T-581-2010; C-299 -2011. Relator: Magistrado Ponente Jorge Iván Palacio Palacio.

Corte Constitucional de Colombia (C.C.). Sentencias T-029-2012; T-573-2010. Relator: Magistrado Ponente Juan Carlos Henao Pérez.

Corte Constitucional de Colombia (C.C.). Sentencias T-187-2014; T-254-2014; T270-2014; T-342-2014; T-566-2013; T-831A-2013; T-888-2013; T-702-2012; T-088-2011; T454-2012; T-740-2012; T-484-2011. Colombia. Relator: Magistrado Ponente Luis Ernesto Vargas Silva.

. Corte Constitucional de Colombia (C.C.). Sentencias T-019-2014; T-432-2014; T833-2014. Relator: Magistrado Ponente Luis Guillermo Guerrero Pérez.

Corte Constitucional de Colombia (C.C.). Sentencias T-064-2009; T-643-2006; T894-2005; T-791-2004. Relator: Magistrado Ponente Jaime Araujo Rentería.

Corte Constitucional de Colombia (C.C.). Sentencia T-815-2002. Relator: Magistrado Ponente Jaime Córdoba Triviño.

. Corte Constitucional de Colombia (C.C.). Sentencias T-556-1998; T-394-1997. Relator: Magistrado Ponente José Gregorio Hernández Galindo.

. Corte Constitucional de Colombia (C.C.). Sentencias T-646-2007; T-025-2004. Relator: Magistrado Ponente Manuel José Cepeda Espinosa.

Corte Constitucional de Colombia (C.C.). Sentencias T-262-2007; T-585-2006. C067-2003. Relator: Magistrado Ponente Marco Gerardo Monroy Cabra.

Corte Constitucional de Colombia (C.C.). Sentencias T-028-2014; T-045-2014; T218-2014; T-721-2014; T-886-2014; T-176-2013; T-675-2011; T-761-2011; T-044-2010; C 912-2013. Relator: Magistrado Ponente María Victoria Calle Correa.

. Corte Constitucional de Colombia (C.C.). Sentencias T-1017-2007; T-238A-2011; T244-2014; T-245-2014. Relator: Magistrado Ponente Mauricio González Cuervo. 
C.C. COLOMBIA. Corte Constitucional de Colombia (C.C.). Sentencias T-099-2014; T-3222014; T-631-2013; T-851-2012; T-106-2011; T-045-2009. Relator: Magistrado Ponente Nilson Pinilla Pinilla.

Corte Constitucional de Colombia (C.C.). Sentencias T-079-2008; T-216A-2008. Relator: Magistrado Ponente Rodrigo Escobar Gil.

Corte Constitucional de Colombia (C.C.). Sentencia T-589-1998. Relator: Magistrado Ponente Rosalba Rodríguez de Puentes. 


\section{APÊNDICES}

Apêndice A. Palavras-chave utilizadas para a seleção de documentos pertinentes no âmbito multilateral, institucional, acadêmico, jurídico e social mediado pelo judiciário.

Apêndice B. Os instrumentos jurídicos Internacionais em permeabilidade com 0 direito à moradia.

Apêndice C. Constituições vigentes da Colômbia e da Espanha. Comparação de artigos associados com o direito à moradia.

Apêndice D. Esquemas argumentativos sobre o direito à moradia, desde sentencias da Corte Constitucional da Colômbia. 
APÊNDICE A. Palavras-chave utilizadas para a seleção de documentos pertinentes no âmbito multilateral, institucional, acadêmico, jurídico e social mediado pelo judiciário.

\begin{tabular}{|c|c|c|c|}
\hline $\begin{array}{l}\text { Documentos da Organização das } \\
\text { Nações Unidas (ONU). } \\
\text { Âmbito multilateral }\end{array}$ & $\begin{array}{l}\text { Constituições dos } \\
\text { Países da América } \\
\text { Latina. } \\
\text { Âmbito jurídico- } \\
\text { institucional }\end{array}$ & $\begin{array}{l}\text { Produção de } \\
\text { acadêmicos. } \\
\text { Âmbito acadêmico }\end{array}$ & $\begin{array}{l}\text { Sentencias da Corte } \\
\text { Constitucional da } \\
\text { Colômbia. } \\
\text { Âmbito social } \\
\text { mediado pelo } \\
\text { judiciário }\end{array}$ \\
\hline $\begin{array}{l}\text { Primeiras palavras-chave aplicadas: } \\
\text { Agua } \\
\text { Albergue } \\
\text { Asentamientos humanos } \\
\text { Dignidad } \\
\text { Derechos civiles y políticos } \\
\text { Derechos económicos y sociales } \\
\text { Energía } \\
\text { Medio ambiente } \\
\text { Medio humano } \\
\text { Planificación } \\
\text { Urbanismo } \\
\text { Urbanización } \\
\text { Saneamiento } \\
\text { Vivienda } \\
\text { Palavras-chave encontradas na } \\
\text { primeira revisão: } \\
\text { Cambio climático } \\
\text { Cooperación técnica } \\
\text { Derechos de los niños, impedidos, } \\
\text { mujeres, refugiados, discapacitados } \\
\text { Derechos humanos } \\
\text { Desplazados } \\
\text { Erradicación de la pobreza } \\
\text { Estándar de vida } \\
\text { Hábitat } \\
\text { Necesidades básicas } \\
\text { Nivel de vida } \\
\text { Microcrédito } \\
\text { Personas sin hogar } \\
\text { Propiedad } \\
\text { Refugiados } \\
\text { Sida }\end{array}$ & $\begin{array}{l}\text { Indicadores de } \\
\text { habitação dos } \\
\text { países da América } \\
\text { Latina. } \\
\text { Âmbito institucional } \\
\text { Não utilizamos } \\
\text { palavras-chave }\end{array}$ & $\begin{array}{l}\text { Português: } \\
\text { Habitação adequada } \\
\text { Habitação digna } \\
\text { Moradia digna } \\
\text { Moradia adequada } \\
\text { Moradia decente } \\
\text { Moradia dignidade } \\
\text { Dignidade } \\
\\
\text { Espanhol: } \\
\text { Hábitat digno } \\
\text { Vivienda digna } \\
\text { Vivienda adecuada } \\
\text { Vivienda decente } \\
\text { Vivienda dignidad } \\
\text { Dignidad }\end{array}$ & $\begin{array}{l}\frac{\text { Palavra-chave }}{\text { aplicada: }} \\
\text { Vivienda digna. } \\
\text { Palavras-chave } \\
\text { encontradas na } \\
\text { primeira revisão: } \\
\text { Albergue temporal } \\
\text { Ambiente sano } \\
\text { Amparo transitório } \\
\text { Derecho a la vivienda } \\
\text { Intimidad } \\
\text { Mínimo vital } \\
\text { Núcleo esencial } \\
\text { Predio rural } \\
\text { Proyecto productivo } \\
\text { Privacidad } \\
\text { Trato preferencial }\end{array}$ \\
\hline
\end{tabular}

Quadro A1 - Palavras-chave utilizadas para a seleção de documentos pertinentes no âmbito multilateral, institucional, acadêmico, jurídico e social mediado pelo judiciário.

Fonte: Elaboração própria 
APÊNDICE B. Os instrumentos jurídicos Internacionais em permeabilidade com $\mathrm{O}$ direito à moradia

\section{Critérios de análise dos instrumentos jurídicos de direito internacional}

A permeabilidade dos direitos é relatada por Leckie como um estado cujos instrumentos jurídicos de direito internacional possuem um conjunto de elementos que os vinculam de maneira direta a outros direitos existentes (1992, p. 41).

A revisão dos documentos da ONU, os instrumentos que a Defensoría del Pueblo da Colômbia (2009) estabelece dentro de seu Bloque de Constitucionalidad como permeados com o direito à moradia, além de mais alguns encontrados na análise das sentencias, permitiu estabelecer os instrumentos de direito internacional que poderiam ser permeados com o direito à moradia, ou seja, que manifestassem clara conexão com esse direito. Após o ordenamento dos instrumentos selecionados, do mais antigo para o mais recente, procedeu-se à busca, no conteúdo dos instrumentos, de palavras-chave que correspondessem a variáveis dos indicadores para moradia, que decorrem do guia de especialistas das Naciones Unidas (1961, p. 1), assim como as variáveis do déficit habitacional aplicados, hoje, nos países da América Latina.

A maioria dos instrumentos jurídicos de direito internacional foram localizados nos sites de documentação virtual da $\mathrm{ONU}^{139} \mathrm{e}$, em menor número, nas bibliotecas de universidades com textos on-line e impressos. Quanto aos idiomas oficiais da ONU, são seis: árabe, chinês, espanhol, francês, inglês e russo. Procurou-se revisar os documentos oficiais em espanhol, por ser o idioma mais aproximado do português, em termos de vocabulário e estrutura, e a língua nativa da autora desta pesquisa. A revisão de tão ampla quantidade de textos fundamentou-se na análise documental.

Deste modo, o Quadro B1 apresenta um compêndio dos instrumentos jurídicos internacionais em permeabilidade com o direito à moradia; configurado pela coluna "subcategorias", que corresponde a variáveis de habitabilidade, como por exemplo: água, energia, intimidade, adensamento, etc. As categorias gerais que classificam as subcategorias são baseadas nas categorias do livro Desarrollo a Escala Humana de Max-Neef (1993, p. 54) no qual se estabelece um conjunto de necessidades humanas fundamentais, como: subsistência, proteção, afeto, entendimento, participação, lazer e criação.

139 Para os sites de documentação virtual da ONU, ver Nota de Rodapé No.5. 


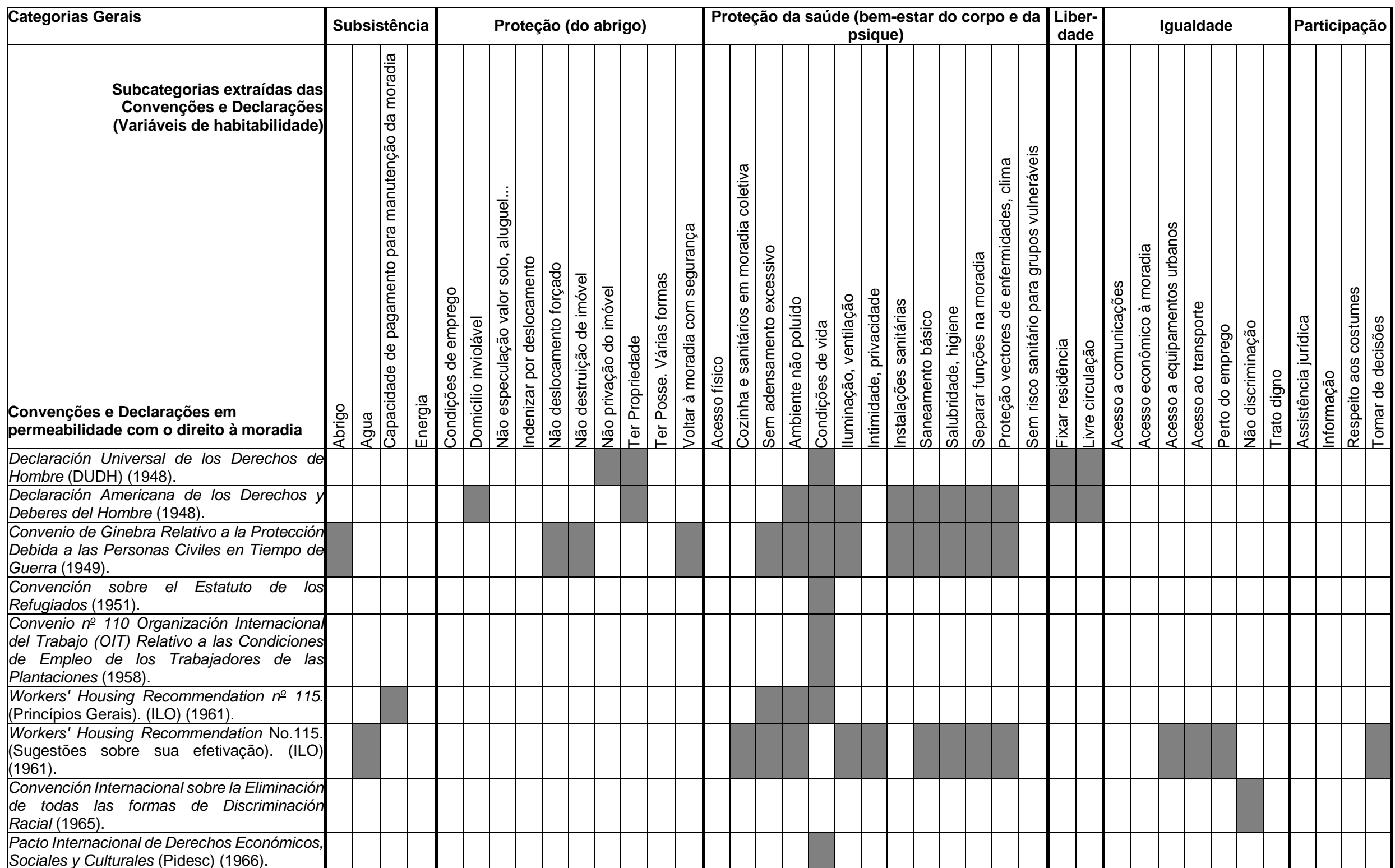




\begin{tabular}{|c|c|c|c|c|c|c|c|c|c|c|c|c|c|c|c|c|c|c|c|c|c|c|c|c|c|c|c|c|c|c|c|c|c|c|c|c|c|c|c|c|}
\hline \begin{tabular}{|r|} 
Categorias Gerais \\
\\
Subcategorias extraídas das \\
Convenções e Declarações \\
(Variáveis de habitabilidade)
\end{tabular} & \multicolumn{4}{|c|}{ Subsistência } & \multicolumn{10}{|c|}{ Proteção (do abrigo) } & \multicolumn{13}{|c|}{$\begin{array}{c}\text { Proteção da saúde (bem-estar do corpo e da } \\
\text { psique) }\end{array}$} & \multicolumn{2}{|c|}{\begin{tabular}{c|c|c|c|} 
Liber- \\
dade
\end{tabular}} & \multicolumn{7}{|c|}{ Igualdade } & \multicolumn{4}{|c|}{ Participaçãc } \\
\hline $\begin{array}{r}\text { Subcategorias extraídas das } \\
\text { Convenções e Declarações } \\
\text { (Variáveis de habitabilidade) }\end{array}$ & 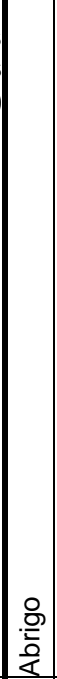 & $\frac{\mathbb{\pi}}{3}$ & 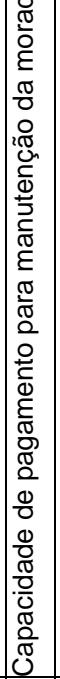 & \begin{tabular}{|l|}
$\frac{\pi}{0}$ \\
$\frac{\pi}{0}$ \\
$\frac{\bar{w}}{\Psi}$ \\
\end{tabular} & 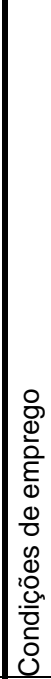 & 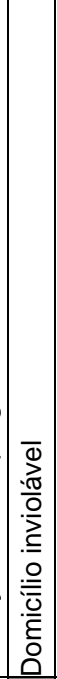 & 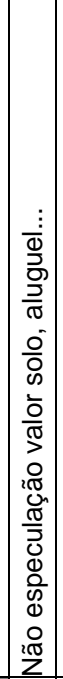 & 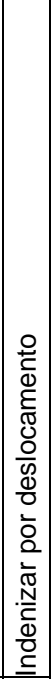 & 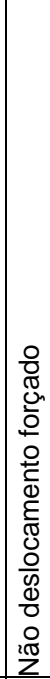 & 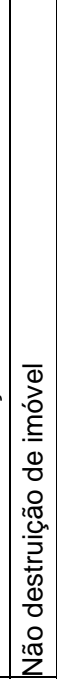 & 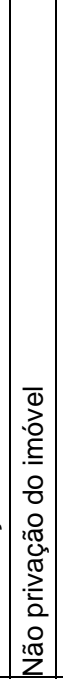 & 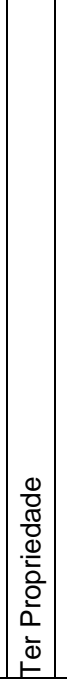 & 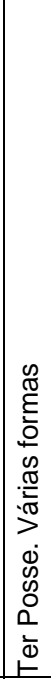 & 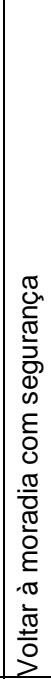 & 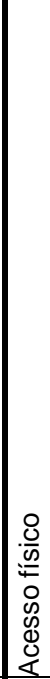 & 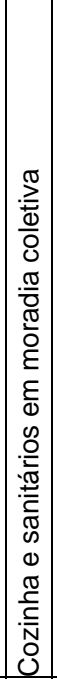 & 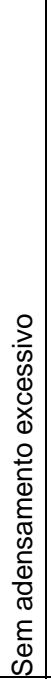 & 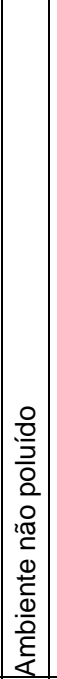 & 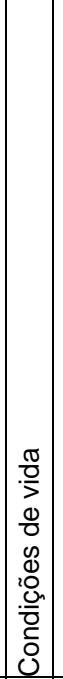 & 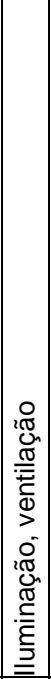 & 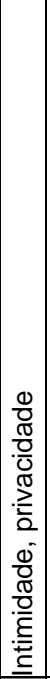 & 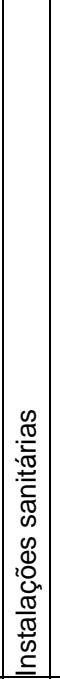 & 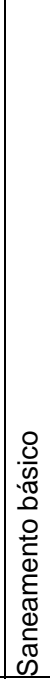 & 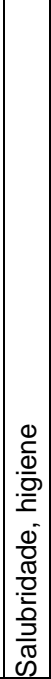 & 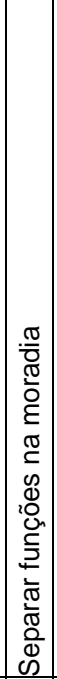 & 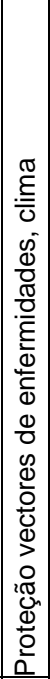 & 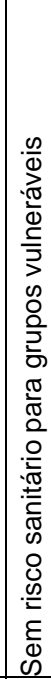 & 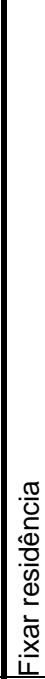 & 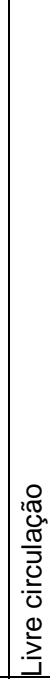 & 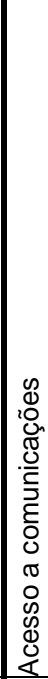 & 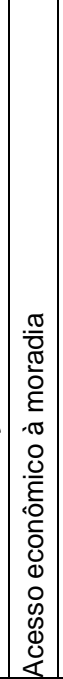 & 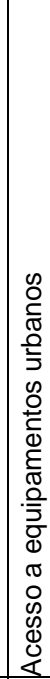 & 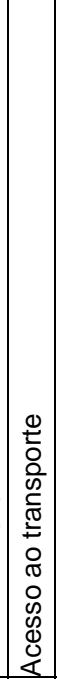 & 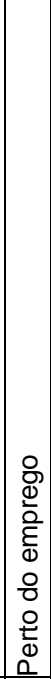 & 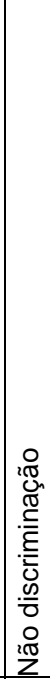 & 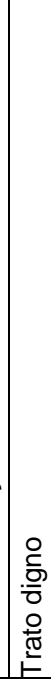 & 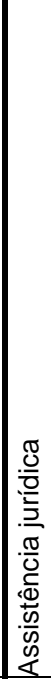 & 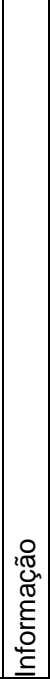 & 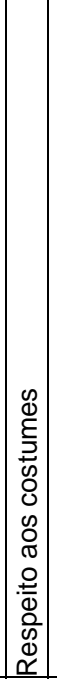 & 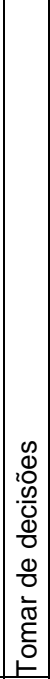 \\
\hline \multicolumn{40}{|c|}{ 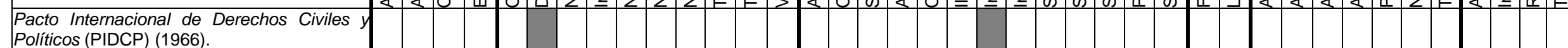 } & \\
\hline \multicolumn{41}{|l|}{ 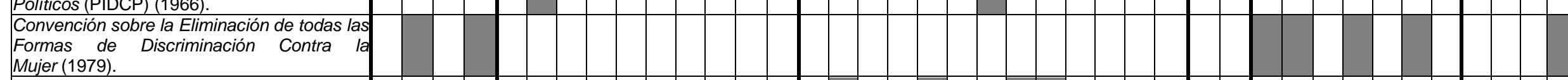 } \\
\hline \multicolumn{41}{|l|}{$\begin{array}{l}\text { Convenio } n^{0} 161 \text { Organización Internacional } \\
\text { del Trabajo (OIT) Relativo a los Servicios de } \\
\text { Salud en el Trabajo (1985). }\end{array}$} \\
\hline \multicolumn{41}{|l|}{$\begin{array}{l}\text { Protocolo Adicional a La Convención } \\
\text { Americana sobre Derechos Humanos en } \\
\text { Materia de Derechos Económicos, Sociales y } \\
\text { Culturales "Protocolo De San Salvador } \\
\text { (1988). }\end{array}$} \\
\hline \multicolumn{41}{|l|}{$\begin{array}{l}\text { Convención sobre Los Derechos Det } \\
\text { Niño (1989). }\end{array}$} \\
\hline \multicolumn{41}{|l|}{$\begin{array}{l}\text { Convención Internacional sobre la Protección } \\
\text { de los Derechos de todos los Trabajadores } \\
\text { Migratorios y de sus Familiares (1990). }\end{array}$} \\
\hline \multicolumn{41}{|l|}{$\begin{array}{l}\text { Principios de la Higiene de la Vivienda. } \\
\text { Organización Mundial de la Salud (OMS) } \\
(1990) \text {. }\end{array}$} \\
\hline $\begin{array}{l}\text { Observación General no 4: El Derecho a una } \\
\text { Vivienda Adecuada. (Pidesc) (1991). }\end{array}$ & & & & & & & & & & & & & & & & & & & & & & & & & & & & & & & & & & & & & & & & \\
\hline
\end{tabular}




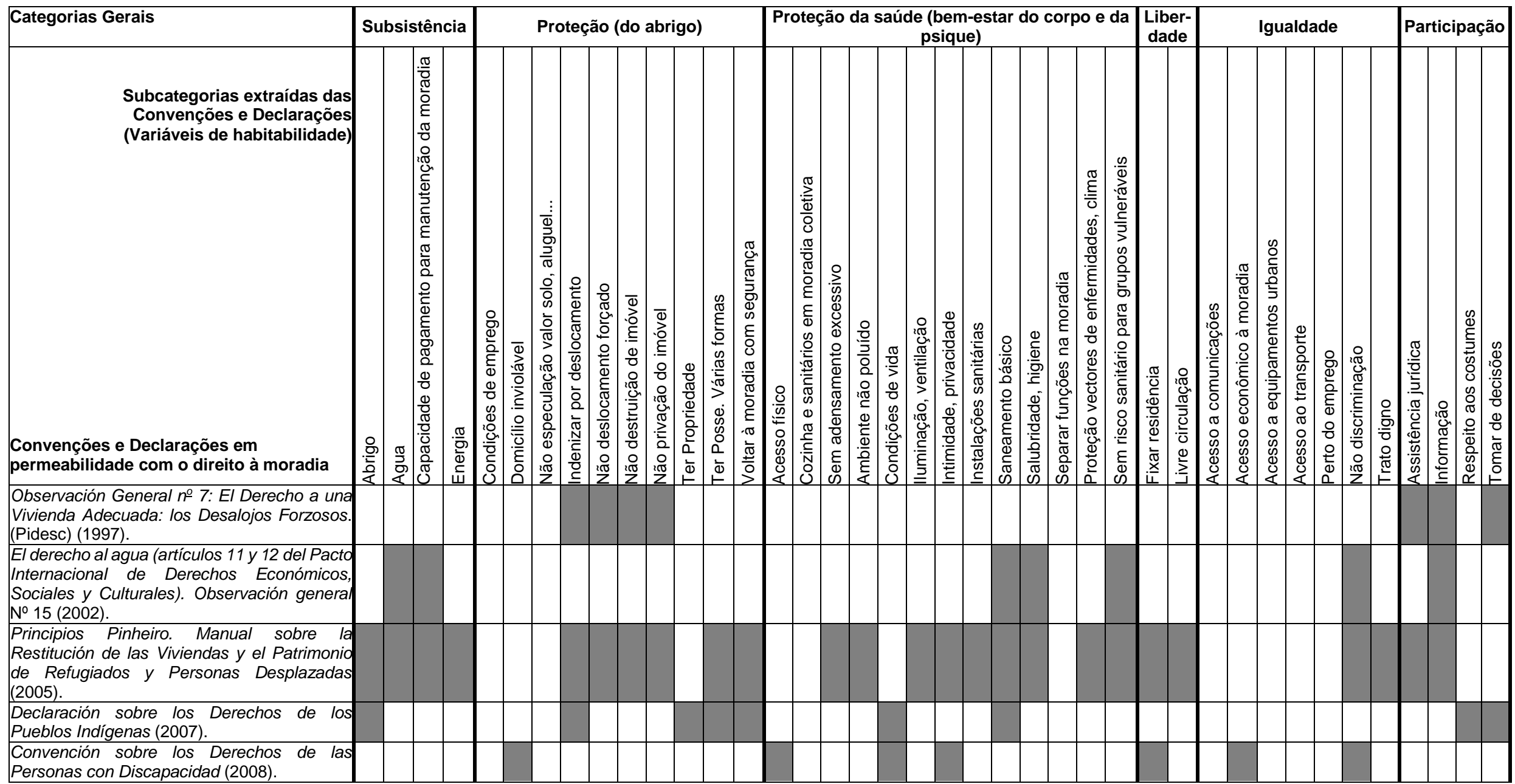

Personas con Discapacidad (2008).

Quadro B1 - Instrumentos jurídicos internacionais em permeabilidade com o direito à moradia.

Fonte: Elaboração própria baseada nos Instrumentos Internacionais da Organização das Nações Unidas, na ordem de aparição neste Quadro: Asamblea General (1948); Comisión Interamericana de Derechos Humanos (1948); Naciones Unidas (1949); Naciones Unidas (1951); OIT (1958); OIT (1961); Naciones Unidas (1965); Asamblea General (1966); Naciones Unidas (1979); OIT (1985); ONU (1988); Naciones Unidas (1989); Naciones Unidas (1990); Organización Mundial de la Salud (1990); Comité de Derechos Económicos, Sociales y Culturales (1991); Comité de Derechos Económicos, Sociales y Culturales (1997); Naciones Unidas (2002); Naciones Unidas (2005); Naciones Unidas (2007); Naciones Unidas (2008). 


\section{APÊNDICE C. Constituições vigentes da Colômbia e da Espanha. Comparação de artigos associados com o direito à moradia.}

\begin{tabular}{|c|c|c|}
\hline $\begin{array}{ll}\text { Tipo de } \\
\text { direito }\end{array}$ & Constitución Española. 1978 & $\begin{array}{l}\text { Constitución de la República de } \\
\text { Colombia. } 1991\end{array}$ \\
\hline $\begin{array}{l}\text { Direito } \\
\text { moradia }\end{array}$ & $\begin{array}{l}\text { "Todos los españoles tienen derecho a } \\
\text { disfrutar de una vivienda digna y } \\
\text { adecuada. Los poderes públicos } \\
\text { promoverán las condiciones necesarias y } \\
\text { establecerán las normas pertinentes para } \\
\text { hacer efectivo este derecho, regulando la } \\
\text { utilización del suelo de acuerdo con el } \\
\text { interés general para impedir la } \\
\text { especulación." (Art. 47). }\end{array}$ & $\begin{array}{l}\text { "Todos los colombianos tienen derecho a } \\
\text { vivienda digna. El Estado fijará las condiciones } \\
\text { necesarias para hacer efectivo este derecho y } \\
\text { promoverá planes de vivienda de interés social, } \\
\text { sistemas adecuados de financiación a largo } \\
\text { plazo y formas asociativas de ejecución de estos } \\
\text { programas de vivienda." (Art. 51). }\end{array}$ \\
\hline $\begin{array}{l}\text { Direito de } \\
\text { Propriedade }\end{array}$ & $\begin{array}{l}\text { "Se reconoce el derecho a la propiedad } \\
\text { privada y a la herencia. (...). Nadie podrá } \\
\text { ser privado de sus bienes y derechos sino } \\
\text { por causa justificada de utilidad pública o } \\
\text { interés social, mediante la } \\
\text { correspondiente indemnización y de } \\
\text { conformidad con lo dispuesto por las } \\
\text { leyes." (Art. 33). }\end{array}$ & $\begin{array}{l}\text { "Se garantizan la propiedad privada y los demás } \\
\text { derechos adquiridos con arreglo a las leyes } \\
\text { civiles, los cuales no pueden ser desconocidos ni } \\
\text { vulnerados por leyes posteriores. Cuando de la } \\
\text { aplicación de una ley expedida por motivo de } \\
\text { utilidad pública o interés social, resultaren en } \\
\text { conflicto los derechos de los particulares con la } \\
\text { necesidad por ella reconocida, el interés privado } \\
\text { deberá ceder al interés público o social. (...). Por } \\
\text { motivos de utilidad pública o de interés social } \\
\text { definidos por el legislador, podrá haber } \\
\text { expropiación mediante sentencia judicial e } \\
\text { indemnización previa." (Art. 58). } \\
\text { "Es deber del Estado promover el acceso } \\
\text { progresivo a la propiedad de la tierra de los } \\
\text { trabajadores agrarios, en forma individual o } \\
\text { asociativa, (...)." (Art. 64). }\end{array}$ \\
\hline $\begin{array}{l}\text { Direito à } \\
\text { inviolabilidade } \\
\text { do domicílio }\end{array}$ & $\begin{array}{l}\text { "El domicilio es inviolable. Ninguna } \\
\text { entrada o registro podrá hacerse en él sin } \\
\text { consentimiento del titular o resolución } \\
\text { judicial, salvo en caso de flagrante delito." } \\
\text { (Art. 18). }\end{array}$ & $\begin{array}{l}\text { "Toda persona es libre. Nadie puede ser } \\
\text { molestado en su persona o familia, ni reducido a } \\
\text { prisión o arresto, ni detenido, ni su domicilio } \\
\text { registrado, sino en virtud de mandamiento escrito } \\
\text { de autoridad judicial competente, con las } \\
\text { formalidades legales y por motivo previamente } \\
\text { definido en la ley." (Art. 28). }\end{array}$ \\
\hline $\begin{array}{l}\text { Direito } \\
\text { intimidade }\end{array}$ & 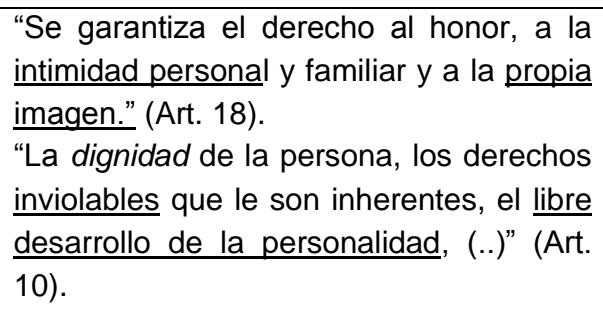 & $\begin{array}{l}\text { "Todas las personas tienen derecho a su } \\
\text { intimidad personal y familiar y a su buen nombre, } \\
\text { y el Estado debe respetarlos y hacerlos respetar." } \\
\text { (Art. 15). } \\
\text { "La honra, la dignidad y la intimidad de la familia } \\
\text { son inviolables." (Art. 42). }\end{array}$ \\
\hline $\begin{array}{l}\text { Liberdade } \\
\text { para escolher } \\
0 \quad \text { lugar de } \\
\text { residencia e } \\
\text { direito à livre } \\
\text { circulação }\end{array}$ & $\begin{array}{l}\text { "Los españoles tienen derecho a elegir } \\
\text { libremente su residencia y a circular por el } \\
\text { territorio nacional. Asimismo, tienen } \\
\text { derecho a entrar y salir libremente de } \\
\text { España en los términos que la ley } \\
\text { establezca. Este derecho no podrá ser } \\
\text { limitado por motivos políticos o } \\
\text { ideológicos." (Art. 19). }\end{array}$ & $\begin{array}{l}\text { "Todo colombiano, con las limitaciones que } \\
\text { establezca la ley, tiene derecho a circular } \\
\text { libremente por el territorio nacional, a entrar y } \\
\text { salir de él, y a permanecer y residenciarse en } \\
\text { Colombia." (Art. 24). }\end{array}$ \\
\hline
\end{tabular}




\begin{tabular}{|c|c|c|}
\hline $\begin{array}{ll}\text { Tipo de } \\
\text { direito }\end{array}$ & Constitución Española. 1978 & $\begin{array}{l}\text { Constitución de la República de } \\
\text { Colombia. } 1991\end{array}$ \\
\hline $\begin{array}{l}\text { Direito ao } \\
\text { ambiente }\end{array}$ & $\begin{array}{l}\text { "1. Todos tienen el derecho a disfrutar de } \\
\text { un medio ambiente adecuado para el } \\
\text { desarrollo de la persona, así como el } \\
\text { deber de conservarlo. } \\
\text { 2. Los poderes públicos velarán por la } \\
\text { utilización racional de todos los recursos } \\
\text { naturales, con el fin de proteger y mejorar } \\
\text { la calidad de la vida y defender y restaurar } \\
\text { el medio ambiente, apoyándose en la } \\
\text { indispensable solidaridad colectiva." (Art. } \\
\text { 45) }\end{array}$ & $\begin{array}{l}\text { "Todas las personas tienen derecho a gozar de } \\
\text { un ambiente sano. La ley garantizará la } \\
\text { participación de la comunidad en las decisiones } \\
\text { que puedan afectarlo" (Art. } 79 \text { ). } \\
\text { "La dirección general de la economía estará a } \\
\text { cargo del Estado. Este intervendrá, por mandato } \\
\text { de la ley, en la explotación de los recursos } \\
\text { naturales, en el uso del suelo, en la producción, } \\
\text { distribución, utilización y consumo de los bienes, } \\
\text { y en los servicios públicos y privados, para } \\
\text { racionalizar la economía con el fin de conseguir } \\
\text { el mejoramiento de la calidad de vida de los } \\
\text { habitantes, la distribución equitativa de las } \\
\text { oportunidades y los beneficios del desarrollo y la } \\
\text { preservación de un ambiente sano." (Art. 334). }\end{array}$ \\
\hline Direito à vida & $\begin{array}{l}\text { "Todos tienen derecho a la vida y a la } \\
\text { integridad física y moral, sin que, en } \\
\text { ningún caso, puedan ser sometidos a } \\
\text { tortura ni a penas o tratos inhumanos o } \\
\text { degradantes." (Art. 15). }\end{array}$ & $\begin{array}{l}\text { "El derecho a la vida es inviolable. No habrá pena } \\
\text { de muerte." (Art. 11). } \\
\text { "Nadie será sometido a desaparición forzada, a } \\
\text { torturas ni a tratos o penas crueles, inhumanos o } \\
\text { degradantes." (Art. 12). }\end{array}$ \\
\hline
\end{tabular}

Quadro C1 - Constituições vigentes da Colômbia e da Espanha. Comparação de artigos associados com o direito à moradia.

Fonte: Elaboração própria com suporte nas Constituições vigentes de Espanha (1978) e da Colômbia (1991).

Sublinhado nosso. 
APÊNDICE D. Esquemas argumentativos sobre o direito à moradia, desde sentencias da Corte Constitucional da Colômbia.

Os esquemas argumentativos, encabeçados por um objeto espacial em litígio, contêm: linhas de jurisprudência, nichos citacionais, pretensões sobre o objeto espacial em litígio, condutas ou ações do demandado, elementos socioespaciais nos quais o demandado escuda a sua conduta e o tipo de lesão que poderia ocorrer, como consequência das condutas ou ações do demandado. Os critérios de sua construção metodológica foram descritos no Item 6.2, no Quadro 6.1 e na Figura 6.1. 


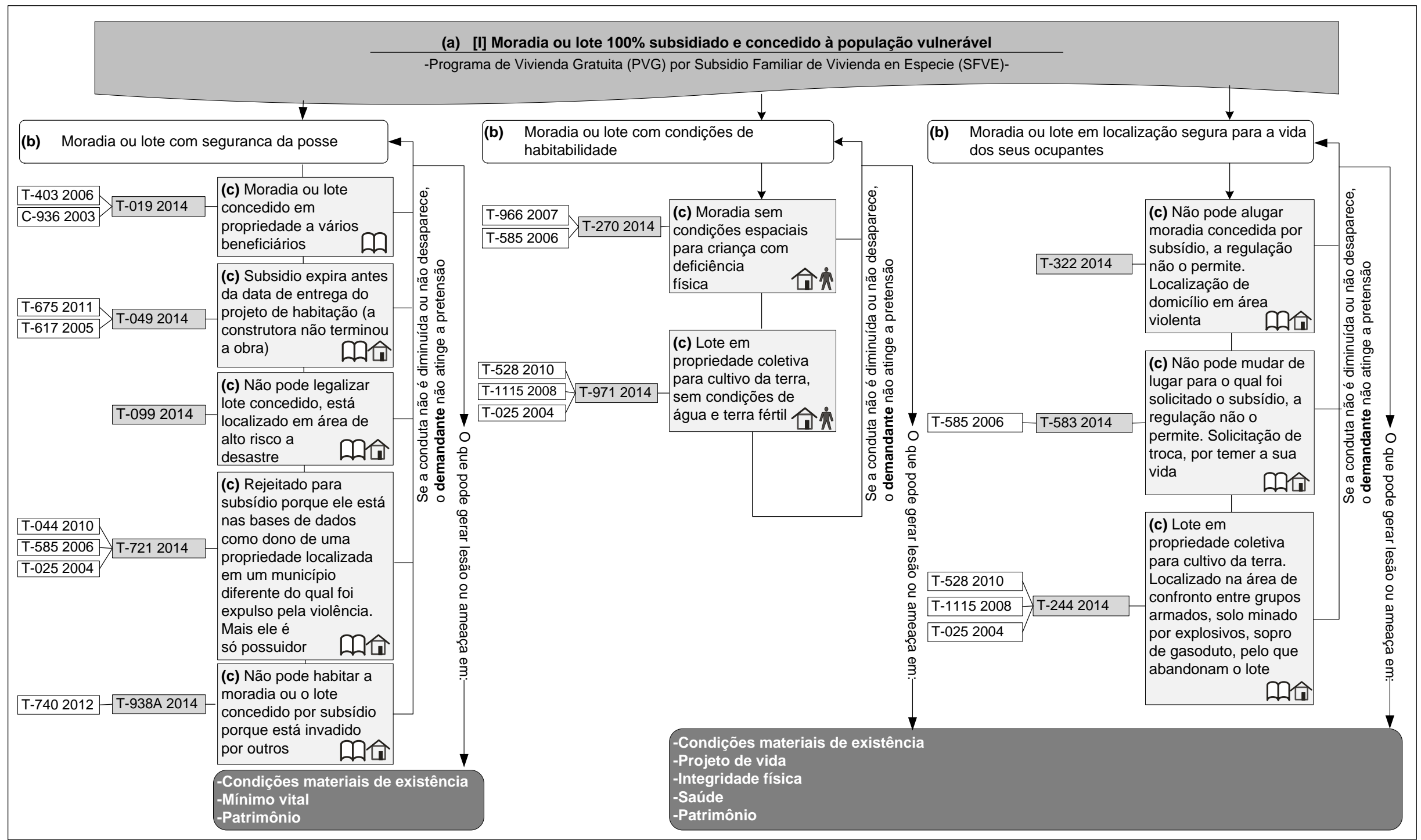

Figura D1 - Esquema argumentativo: [I] Moradia ou lote 100\% subsidiado e concedido à população vulnerável.

Fonte: Elaboração própria. 


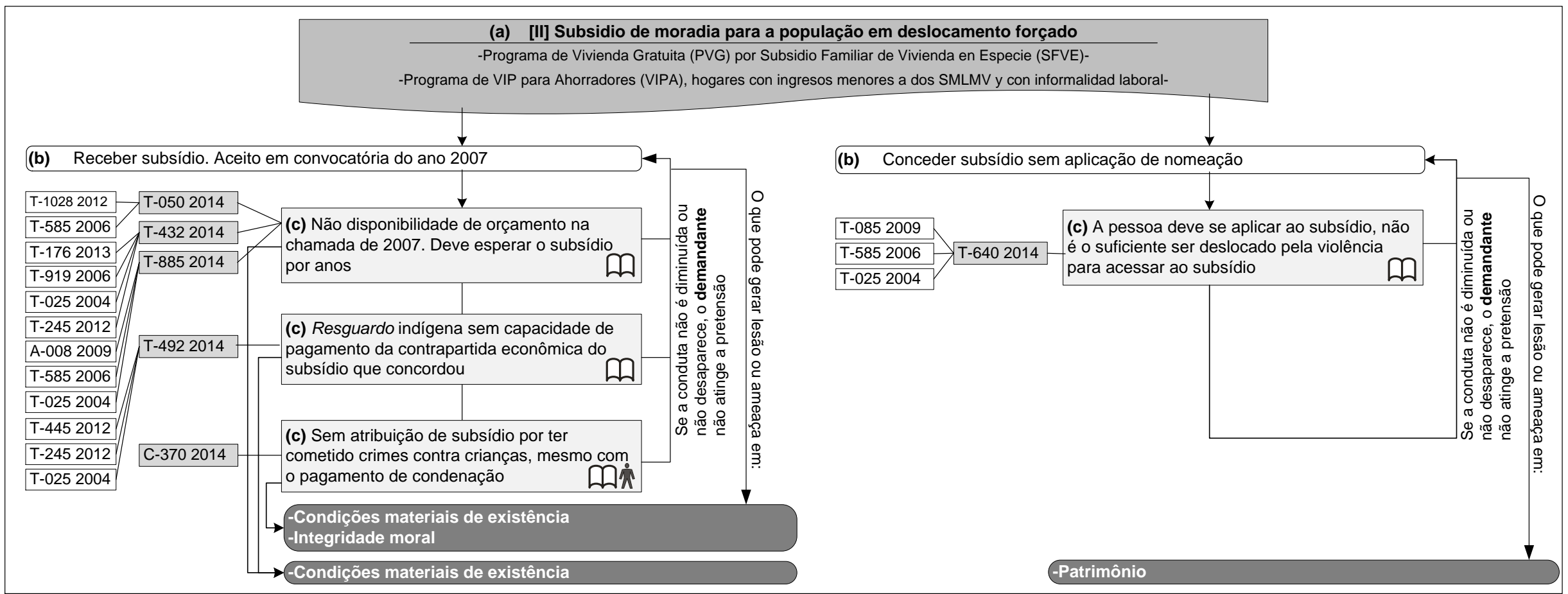

Figura D2 - Esquema argumentativo: [II] subsídio de moradia para a população em deslocamento forçado.

Fonte: Elaboração própria. 


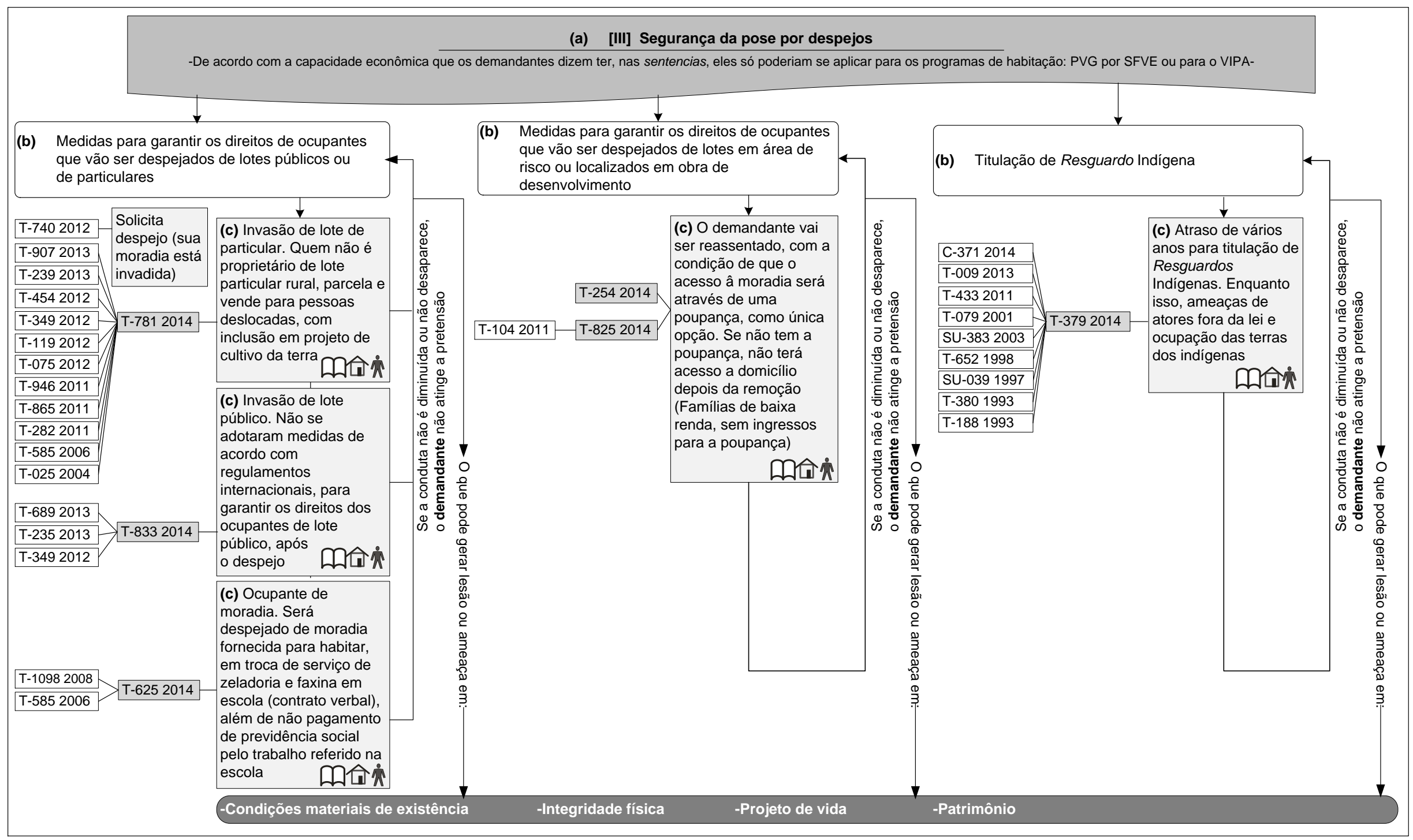

Figura D3 - Esquema argumentativo: [III] Segurança da posse por despejos.

Fonte: Elaboração própria 


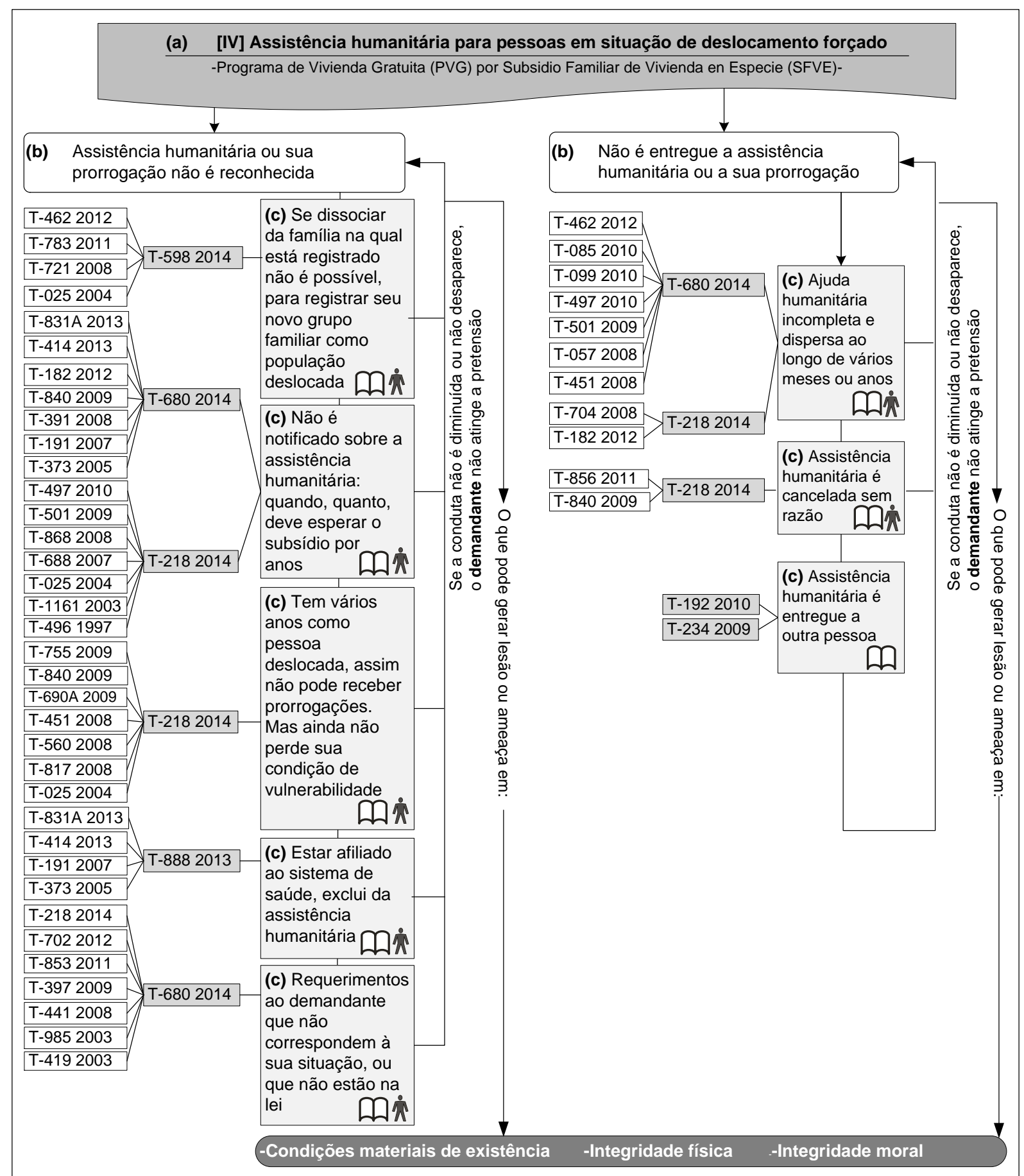

Figura D4 - Esquema argumentativo: [IV] Assistência humanitária para pessoas em situação de deslocamento forçado.

Fonte: Elaboração própria. 


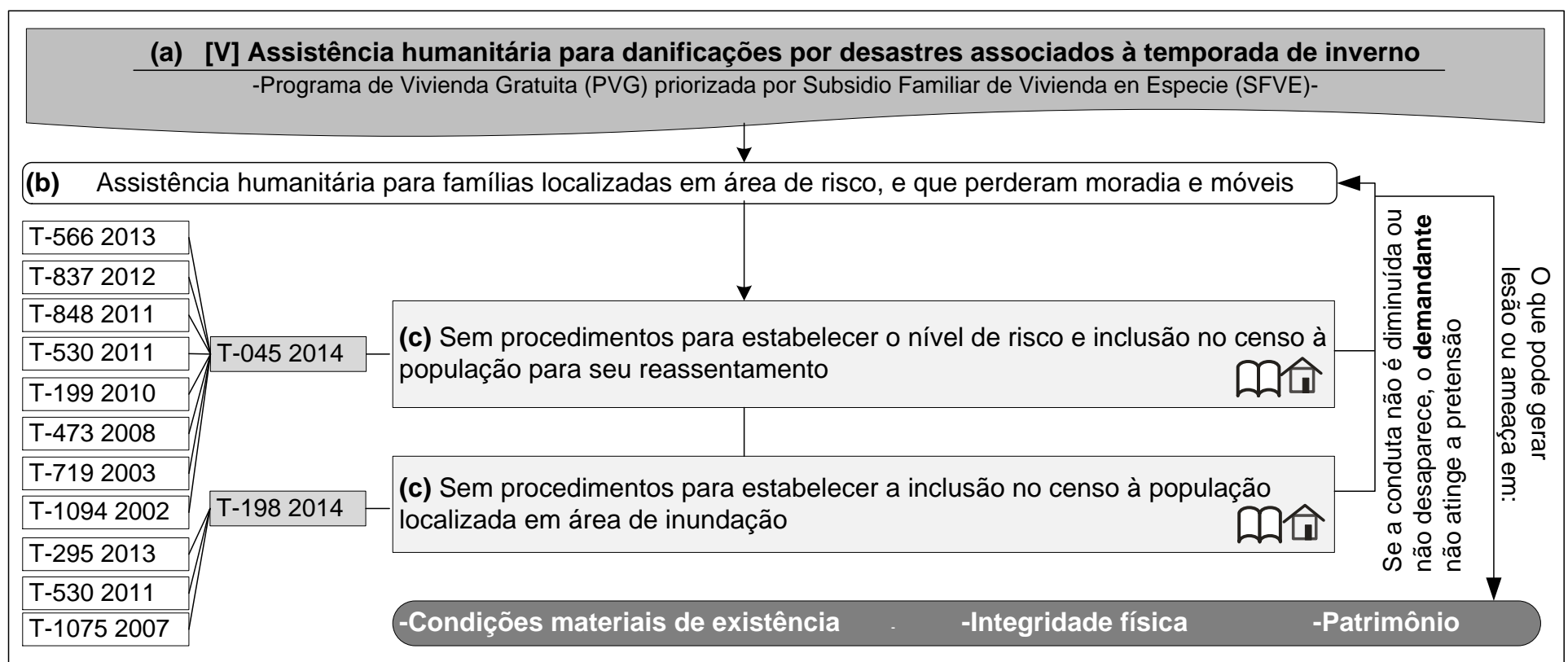

Figura D5 - Esquema argumentativo: [V] Assistência humanitária para danificações por desastres associados à temporada de inverno. Fonte: Elaboração própria. 


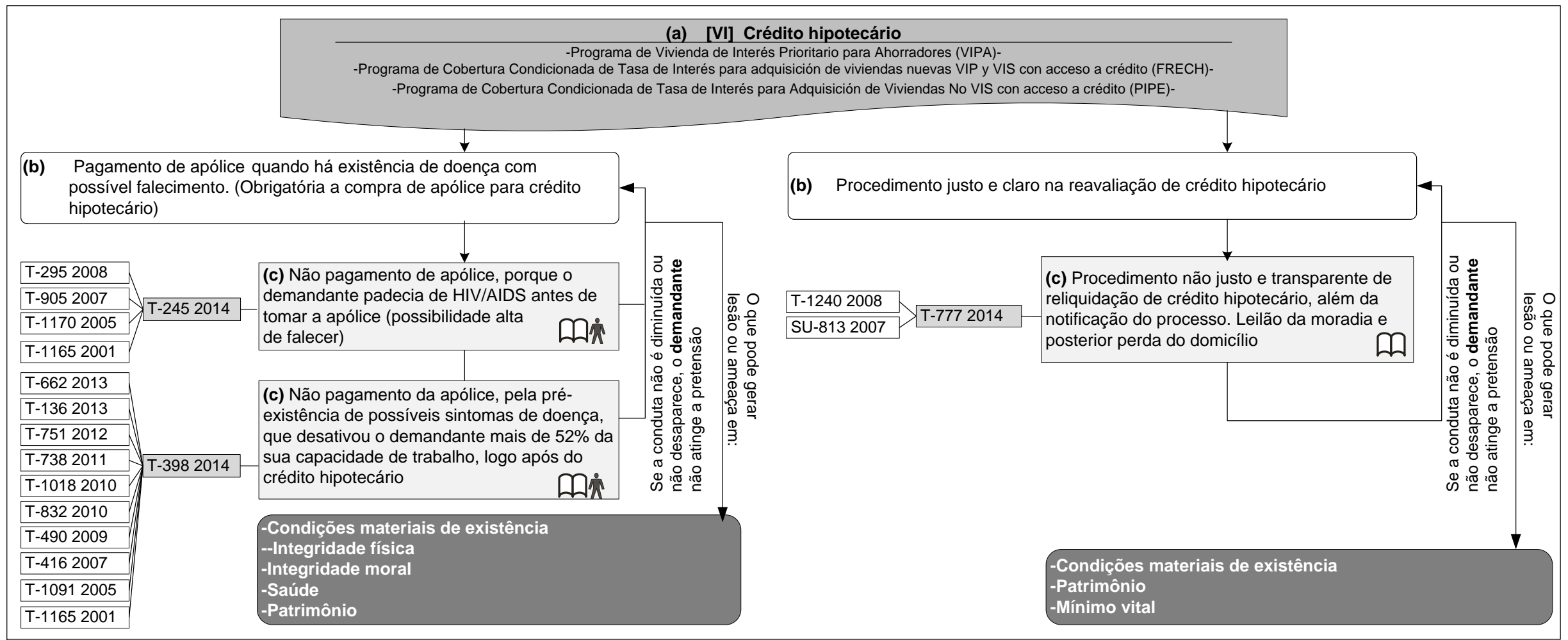

Figura D6 - Esquema argumentativo: [VI] Crédito hipotecário.

Fonte: Elaboração própria. 


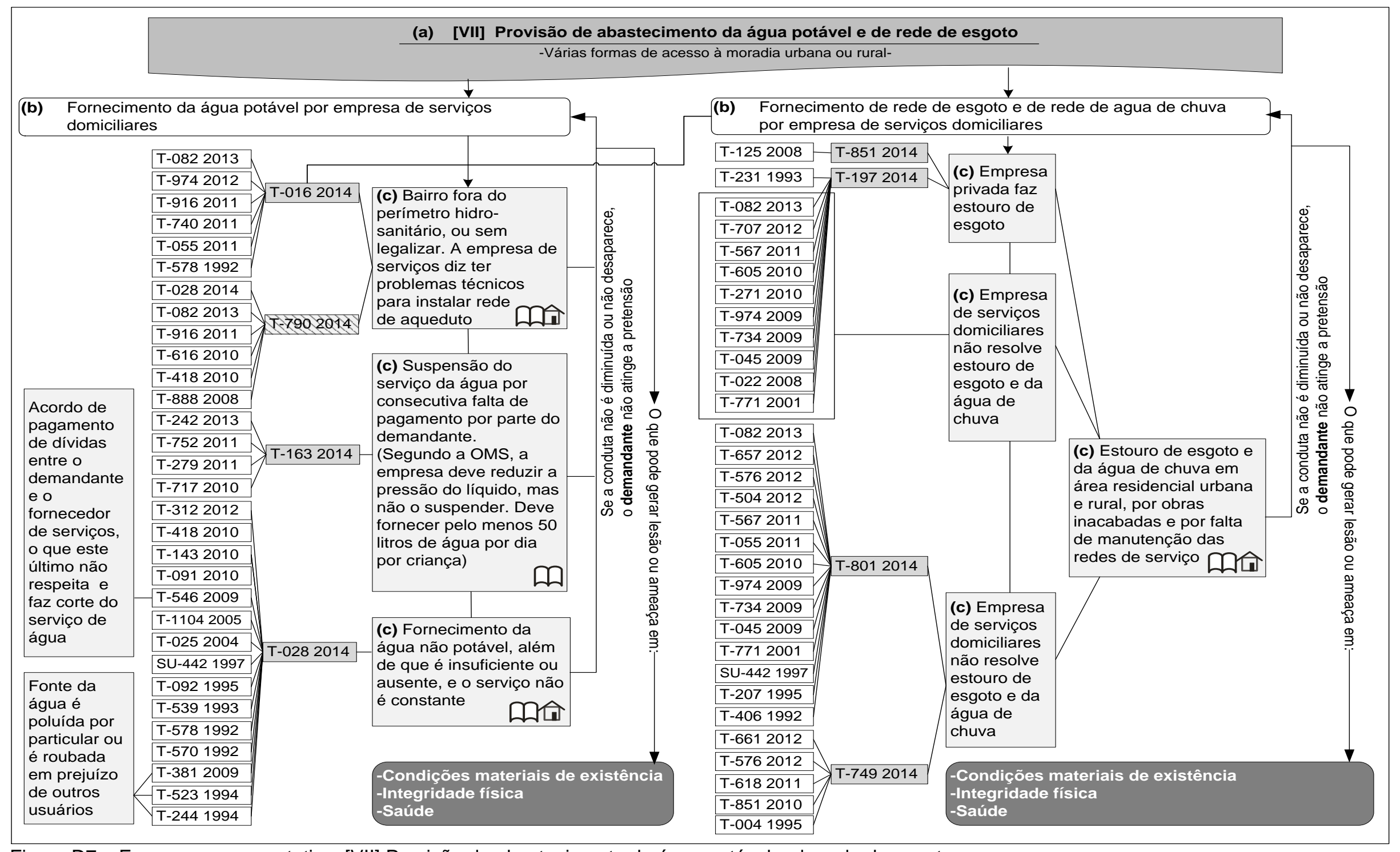

Figura D7 - Esquema argumentativo: [VII] Provisão de abastecimento de água potável e de rede de esgoto.

Fonte: Elaboração própria. 


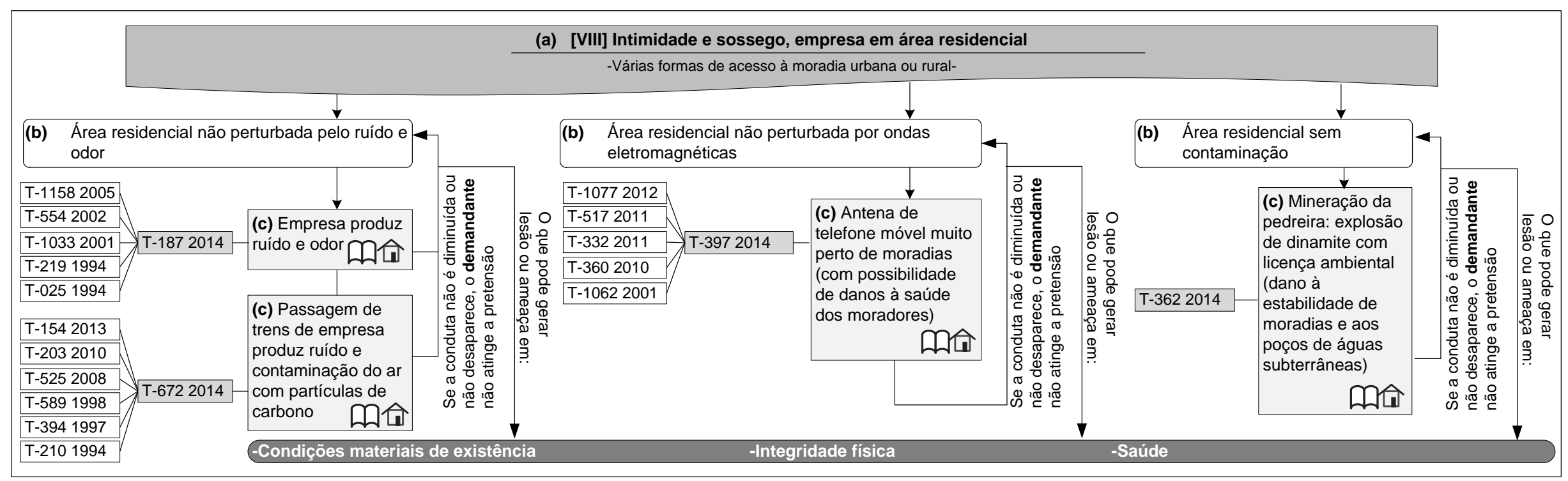

Figura D8 - Esquema argumentativo: [VIII] intimidade e sossego, empresa em área residencial.

Fonte: Elaboração própria. 


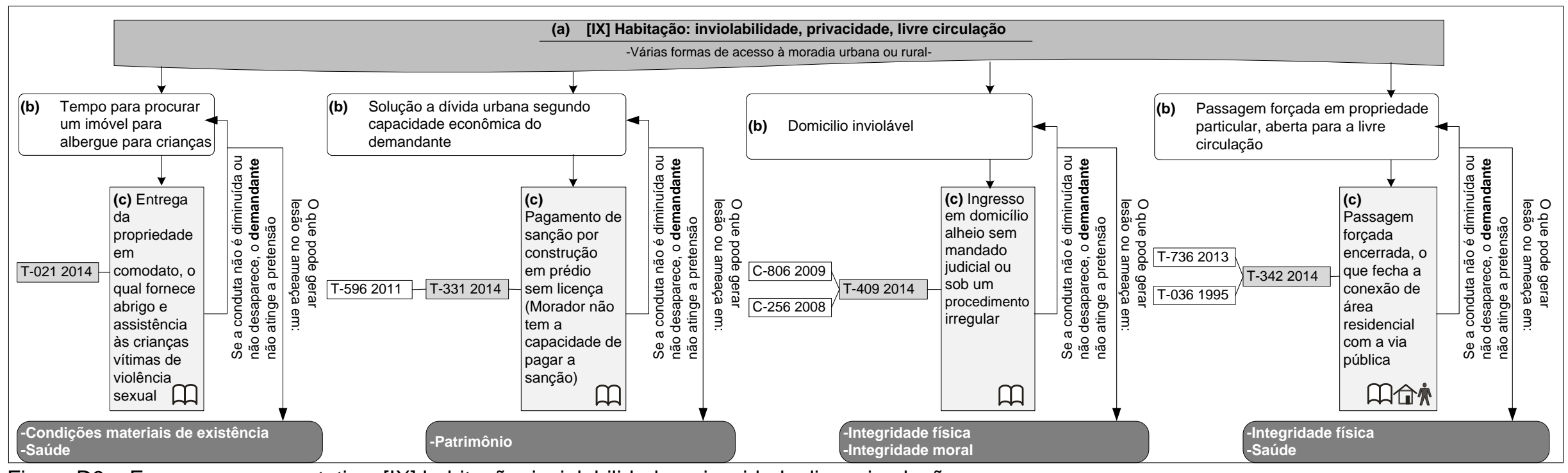

Figura D9 - Esquema argumentativo: [IX] habitação: inviolabilidade, privacidade, livre circulação.

Fonte: Elaboração própria. 
